$\underline{\text { AUSTRALIA }}$

AUSTRALIA.

\title{
POTATO DISEASES
}

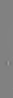

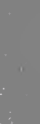
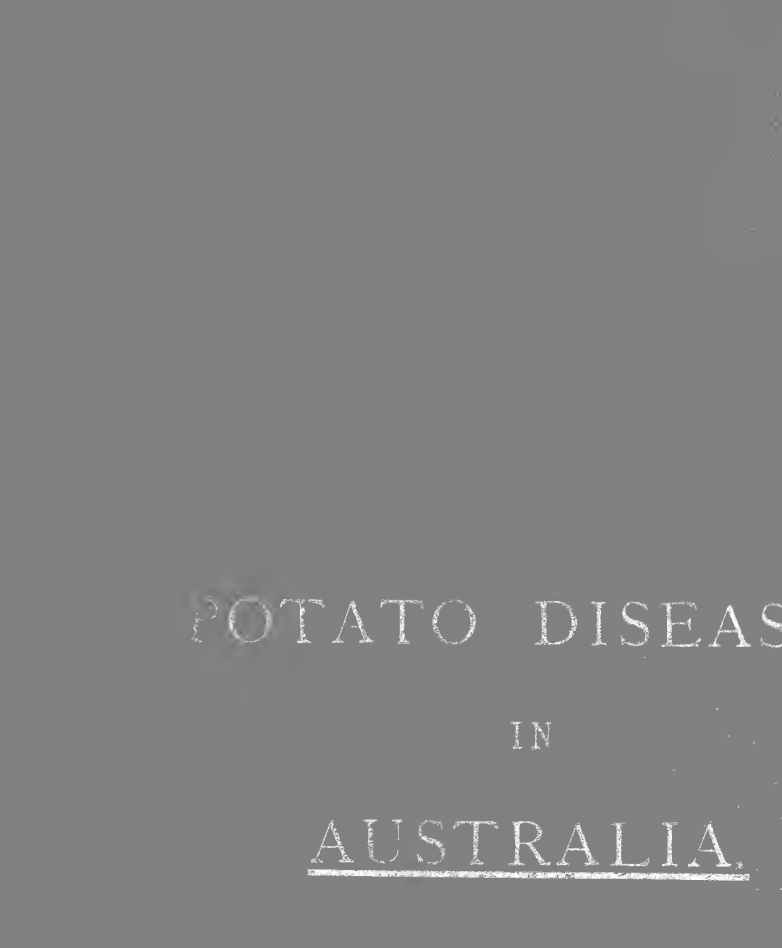


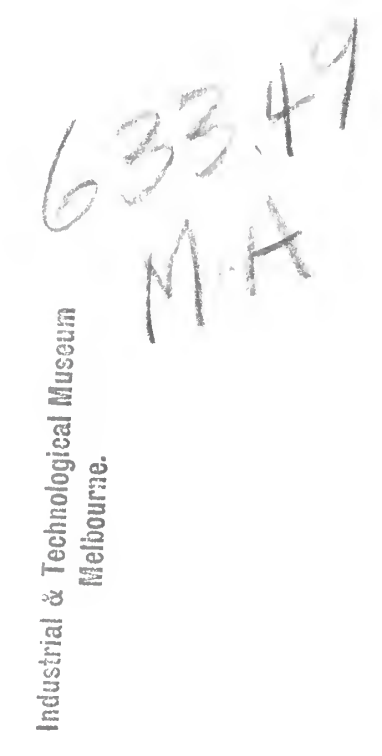


633.491

MCA

MUSEUM OF VICTORIA

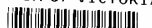





$$
\begin{gathered}
\text { HANDBOOK } \\
\text { POTATO DISEASES } \\
\text { AUSTRAJIA. }
\end{gathered}
$$


, 
. 
Frontispiece.

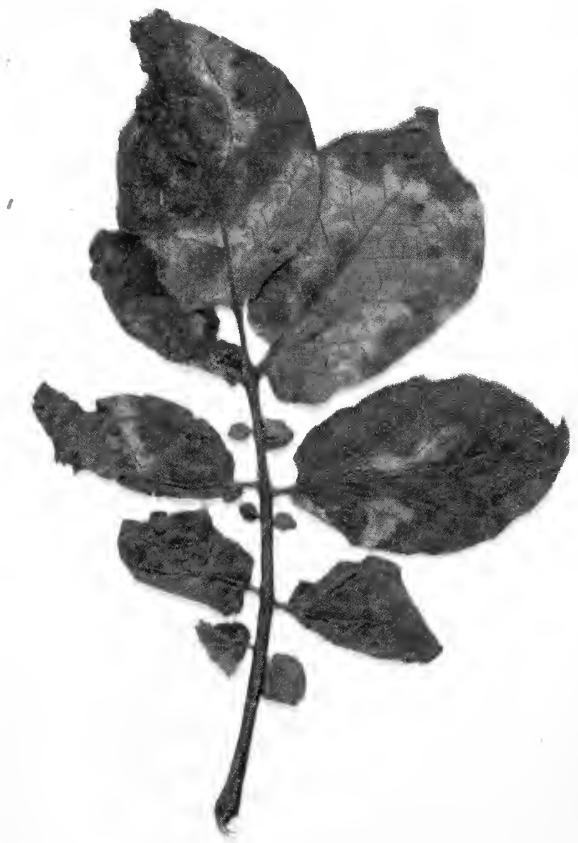

UNDER SURFACE OF BLIGHTED POTATO LEAF, WITH BROWN BLOTCHES AND DENSE WHITE MOULD 
9EP ARTYEXT OF AGRICLITLRE, YITORLA.

Industrial \& Technological Museum Melbourne.

$$
\text { II.1NI)1300I5 }
$$

$1) \mathrm{F}$

HENGUS DISEASES

(1) THE

POT ITO IX ITETRALIX A Y1) NHIIt

$$
\text { 'TRFA'TH M'T. }
$$

BY

1). $\quad M(1,1 \times 1 \times 1 \%$

Gormment Tegrable P'uthologist.

WTH lis FUTRE.

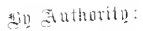

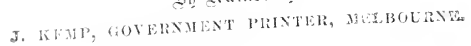




$$
\text { . }
$$




\section{PREFACE.}

It is not to be imagined that potatoes in Anstralia are more subject to disease than in other parts of the world, for oily those diseases are to be found which are more or less common wherever the potato is cultivated. and, as a matter of fact, there are several very serious diseases which have not yet reached us.

Under the heading of "scab" it is shown that some of the worst diseases with which the grower has to contend in Britain and elsewhere are not known here, simply beeause the fungi causing them have not been introduced, and with a Quarantine Act in existence they are not likely to be.

But while this is so, there are quite enongh, including the Potato Blight, to call for the most careful attention on the part of the grower, and the study of the most improved methods of treatment. Besides, the rigid system of inspection carried out under the Vegetation Diseases Act has brought home to the grower, in the most convineing manner, the existence of diseases whieh were previously regarded by him as of little consequence, and there is a natural desire on his part to know sometling of their nature and how they are caused, in order to avoid them, if possible. He soon discovers that, although he may have been growing potatoes for a lifetime, and knows their habits of growth and the proper mode or cultivation, so as to ensure a good crop, yet when disease attacks them the superficial indications do not enable him to get to the bottom of it, and he is confronted with problems foreign to lis experience. Experiments in the laboratory, as well as in the field, are necessary to find out their true nature, and it is the aim of this Handbook to educate the grower, so that he may recognise those diseases which are caused by fungi, and from a study of their peculiarities to adopt such precautions as will either prevent, or at least minimize, their ravages.

Every disease treated of has been personally investigated, and my assistant, Mr. C. $\therefore$ Brittlebank, has rendered valuable help throughout. Mr. Seymour, Potato Expert, has also willingly given me the benefit or his wide experience in all matters relating to the cultivation of the potatn.

Melbourne, September, 1911. 



\section{CONTENTS.}

Introductory

I.-POTATO BLIGHT OR LATE BLIGHT.

Historical

Symptoms of the Disease

Relation of the Fungus to the Disease-

Infection of Tubers with Unbroken Skin

Infection of Tubers with Broken Skin ..

Infection of Potato Tops or Haulms Only

Infection of Tubers Only from Planting Diseased "Sets"

Life History of the Fungus Causing the Disease

Wintering of the Mycelium

Persistent Vitality of the Iycelium

Principal Wodes of Infection

Resting spores...

Conditions under which the Disease Occurs in Australi

Relative Frequency during the Different Months

Distribution in Relation to Rainfall

Tomatoes and Irish Blight

Other Plants Affected

Diseases Associated with Irish Blight ..

Summary of Points of Practical Importance

Factors Influencing the Disease-

$\begin{array}{ll}\text { Heat and Hoisture } & \ldots \\ \text { Temperature } & \ldots \\ \text { Soil Temperatures } & \ldots \\ \text { Soil .. } & \ldots \\ \text { Cultivation } & \ldots \\ \text { Manuring .. } & \ldots \\ \text { Time of Digging } & \ldots \\ \text { Drainage .. } & \ldots \\ \text { Destruetion of Refuse } \\ \text { Dise rse-resisting Varieties }\end{array}$

$\ldots$
$\cdots$
$\cdots$
$\cdots$
$\cdots$
$\cdots$
$\cdots$
$\ldots$

Seed Potatoes-

Age of Seed-Early and Late Dug

Sprouted and Unsprouted Seed

Storage of Seed

How the Potuto Blight is Spread

Seeming Contradictions Reconciled

Distribution of Spores by the Wind

Definite Determination of the Disease

Preventive Theasures

"Steeps" for Seed Potatoes

Prevention by Spraying ..

Disinfection of Seed Potatoes by Dry Heat

The Application of Dry Heat

Experiments with Heated and Unheated Blighted Seed Potatoes at Kardella .

Constituents of the Potato

\section{II.-EARLY BLTGHT OR LEAF SPOT.}

Introductory

Symptoms of the Disease

Conditions Favouring the Disease

Fungus Causing the Disease

Hibernating Mycelium

Host Plants

Treatment

$\begin{array}{ll}\ldots & \ldots \\ \ldots & \cdots \\ \ldots & \cdots \\ \ldots & \cdots \\ \ldots & \cdots \\ \ldots & \ldots\end{array}$

$\ldots$
$\ldots$
$\ldots$
$\ldots$
$\cdots$
$\ldots$

$\begin{array}{lll}\ldots & \ldots & \\ \ldots & \ldots & \\ \ldots & \ldots & \\ \cdots & \ldots & \\ \ldots & \ldots & \\ \ldots & \ldots & \\ \ldots & \cdots & \end{array}$

$\begin{array}{ll}\ldots & 56 \\ \ldots & 56 \\ \ldots & 57 \\ \ldots & 57 \\ \ldots & 58 \\ \ldots & 58 \\ \ldots & 58\end{array}$


II. RHIZOCTONIA BOT.

History and Symptoms of the Disease

..

$\begin{array}{lllll}\text {. } & \ldots & \ldots & \ldots & 00\end{array}$

Host Plants and Pirts Affected ..

('ause of the l)iseitse -

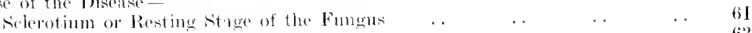

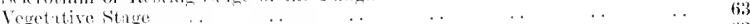

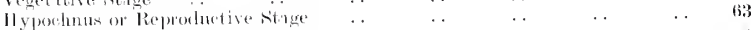

Wiferte of the Fungus

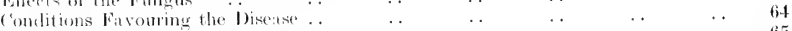

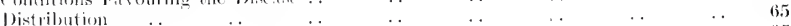

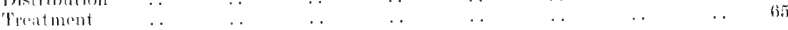

IV. POTATOS S(AB.

lise of the 'lerm kical ..

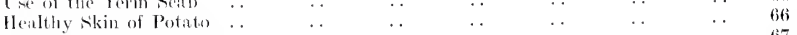

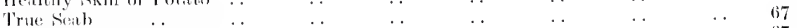

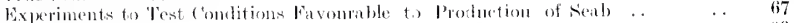

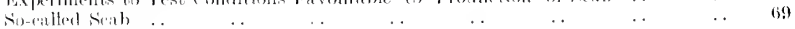

Sieab in tisstralia-

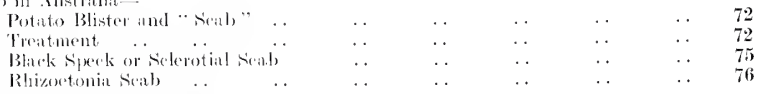

Sitil b in of her Gountries

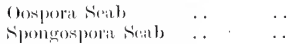

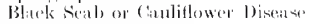

sintef or lory Sinab)

\section{DRI ROT INO BROWN RING:}

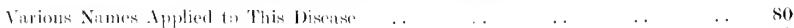

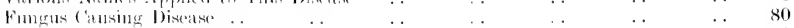

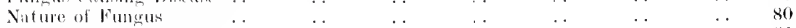

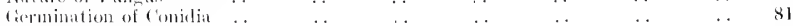

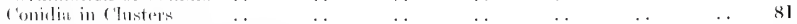

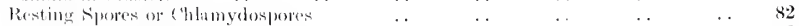

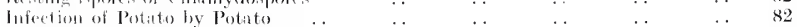

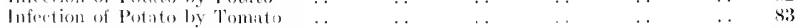

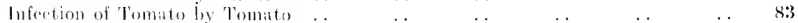

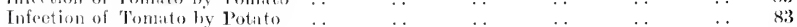

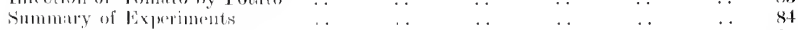

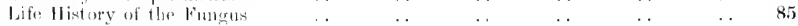

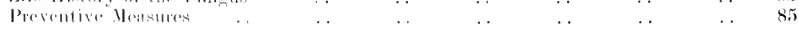

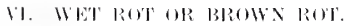

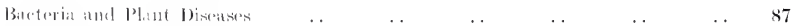

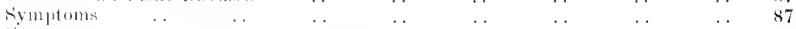

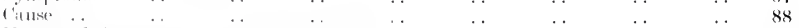

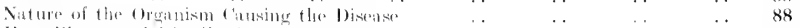

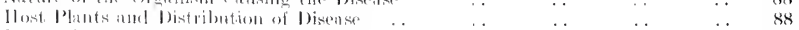

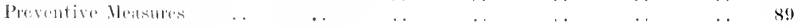

III, B.

Sirmpitoms

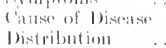

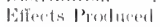

Presentive Mensteres

$\begin{array}{ll}\cdots & \cdots \\ \cdots & \cdots \\ \cdots & \cdots \\ \cdots & \cdots \\ \cdots & \cdots\end{array}$

$\begin{array}{lll}\cdots & \cdots & \cdots \\ \cdots & \cdots & \cdots \\ \cdots & \cdots & \cdots \\ \cdots & \cdots & \cdots\end{array}$

$\begin{array}{lll}\ldots & \ldots & 90 \\ \ldots & \ldots & 90 \\ \ldots & \ldots & 90 \\ \ldots & \ldots & 90 \\ \ldots & \ldots & 90\end{array}$


III.-BLACK DOT DISEASE.

Symptoms

Fungus Causing Disease

Effects Produced

Preventive Measures

IX.-SCLEROTILH DISFASE.

Symptoms

Sclerotium Stage only Known Here

X.-TTRINGI ROT.

"Tree-killing Fungus" the Cause

Nature of Fungus

How it Affects the Potato

Preventive Measures

XI.-BROWN FLEK OR INTERAAL BPGHN SPQT.

Nature of Disease

First Record in Australia

Not a Parasitic Disense ..

Microseopic Structure

Cantes Assigned.

A Physiological Trouble ..

Strain or Streak Disease

Preventive Measures

\section{"MIS'SEN" IN THE I'Y'TATO CROP.}

theneral Considerations

"Threaty Eye " or Spindle Disense

Rhizoctonia

Practical Measures

\begin{tabular}{|c|c|c|c|c|c|}
\hline . & . & $\cdots$ & $\cdots$ & $\cdots$ & $\cdots$ \\
\hline$\cdots$ & . & $\cdots$ & $\ldots$ & $\ldots$ & $\cdots$ \\
\hline . & . & $\cdots$ & $\cdots$ & $\cdots$ & $\cdots$ \\
\hline . & . & $\ldots$ & $\cdots$ & $\cdots$ & $\ldots$ \\
\hline$\cdots$ & .. & $\ldots$ & $\cdots$ & $\cdots$ & $\ldots$ \\
\hline . & . & $\cdots$ & $\cdots$ & $\cdots$ & $\cdots$ \\
\hline - & . & $\cdots$ & $\cdots$ & $\cdots$ & $\ldots$ \\
\hline & . & $\ldots$ & $\cdots$ & $\cdots$ & $\cdots$ \\
\hline
\end{tabular}

\section{I.ENIICELA.}

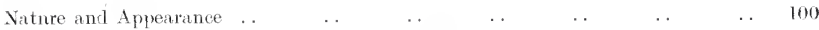

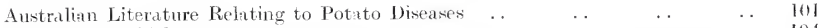

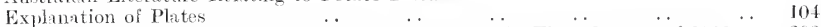

Appendix I.-Weather Conditions over Victoria for the First Quarter of $1911 \ldots 203$ Appendix II.-Regulations Concerning Potrto Diseases in Commonwealth .. 504 Appendix III.-Regulations concerning Potato Discases in St te of Victoria . 206

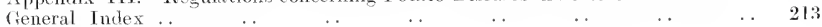
Rainfall Hap of Victoria 
. 


\section{INTRODUCTORY.}

Potatoes are noted for their great liablity to disease, suffering more from the ravages of fungi than any other erop, and this is largely owing to the fact that they are propagated from tubers, which are just swollen portions of underground branches of the stem. Portions of the parent plant, in the form of tubers or cuttings, are planted year after year, so that any inherent weakness in the original is transmitted to the offspring, and thus, without a process of selection, deterioration is sure to occur, sooner or later. When the tubers are raised from seed, as is occasionally done, and a good selection made from. the seedlings, they are said to be less liable to disease, at least for a number of years. This tendency to disease is unwittingly encouraged, owing to the very laudable desire on the part of the grower to choose such varieties for seed-potatoes as yjeld a large-sized, thin-skinned, mealy potato, thus making it more of an artificial product and an easier prey to the inroads of fungi.

It has also to be remembered that potatoes have been a long time under cultivation, from the period of the discovery of America, where cultivation was practised, until it became general in Britain about the beginning of the eighteenth century. They have always been subject to more or less partial failure, and even before the potato blight appeared, the scab and the dry rot were common among them. Now that the potato blight has been discovered in all the States, Australia possesses most of the principal diseases known in other countries.

There is often a complication of diseases in the potato which renders investigation more difficult. Thus the Early Blight and Wet Rot may be associated with the so-called Late Blight; and the Rhizoctonia disease and Eel-worm as well, so that it is not always easy to determine which is the principal cause of the trouble. There are also a number of minor ailments whieh in the aggregate may become serious.

The potato industry is such an important one that whatever tends to improve it is worthy of encouragement, and undoubtedly the study of the diseases to which the potato crop is subject will have good results. I am indebted to the Commonwealth Statistician, Mr. G. H. Knibbs, for the information contained in the following table, which shows the total annual value of the potato industry to the Commonwealth to be over one and a half million pounds sterling, of which Victoria contributed over two-fifths of the whole. Victoria is also the principal potato-growing State as regards area, and is thus vitally interested in the prevention of disease, and if growers would only take the necessary precautions, the average yield per acre might be considerably increased.

Tabre I.-Commonwealth Area under Potatoes, Produce, Average YIETD, AND VALUE.

\begin{tabular}{|c|c|c|c|c|c|c|c|c|c|}
\hline \multirow[t]{2}{*}{ State. } & \multicolumn{2}{|c|}{ Area. } & \multicolumn{2}{|c|}{ rield. } & \multicolumn{2}{|c|}{$\begin{array}{l}\text { Avarage Yield } \\
\text { per Aere. }\end{array}$} & \multicolumn{2}{|c|}{ Vahue of (rop). } & \multirow{2}{*}{$\begin{array}{l}\text { Area. } \\
\text { Acres. }\end{array}$} \\
\hline & Acres. & Acres. & Tons. & Tons. & Tons. & Tons. & \pm & \pm & \\
\hline New South Wales & $\begin{array}{r}1908-9 . \\
26,301\end{array}$ & $\begin{array}{r}1909-10 \\
35,725\end{array}$ & $\begin{array}{r}1908-9 . \\
71,794\end{array}$ & $\begin{array}{r}1909-10 \\
100,143\end{array}$ & $\begin{array}{c}1908-9 \\
2 \cdot 73\end{array}$ & $\begin{array}{c}1909-10 \\
2 \cdot 80\end{array}$ & $\begin{array}{r}1908-9 . \\
372,304\end{array}$ & $\begin{array}{r}1909-10 . \\
461,130\end{array}$ & $\begin{array}{r}1910-11 \\
44,437\end{array}$ \\
\hline Victoria $\quad .$. & 47,903 & 62.390 & 152,840 & 174,9 & $3 \cdot 19$ & $2 \cdot 80$ & 580,792 & 673,635 & 62,904 \\
\hline Queensland $\quad .$. & 6,227 & 7,708 & 11,550 & 13,544 & $1 \cdot 85$ & $1 \cdot 76$ & 92,400 & 94,808 & 8,326 \\
\hline South Australia.. & & 8.13 & 21,5 & 18,5 & $2 \cdot 67$ & $2 \cdot 2$ & 106,542 & 102,1 & 7,472 \\
\hline Western Australia & 2,02 & 1,741 & & & $\cdot 30$ & 3. & 53,500 & 59,4 & 1,791 \\
\hline Tasmania $\quad$. & 35,159 & 21,375 & 121,605 & 73,862 & $3 \cdot 46$ & $3 \cdot 46$ & 425,600 & 246,206 & 26,230 \\
\hline $\begin{array}{c}\text { Total Common- } \\
\text { wealth }\end{array}$ & 125,685 & 137,070 & 386,037 & 387,036 & $3 \cdot 07$ & $2 \cdot 82$ & $1,631,138$ & $1,637,388$ & 151,160 \\
\hline
\end{tabular}


The remarkable falling-off in the area under cultivation in Tramania during 1909 - 10 is chiefly due to the widespread prevalence of potato blight, and to recover lost gromind it will be necessiny to adopt all the modern methods known for coping with it. If we take the United Kingdom for comparison, in 1908 , the arereage moder potatoes was $1,149,000$, and the yield $7,117,000)$ tons, showing that even with potato blight to eontend against, there is still a large area devoted to potatoes, and the average yield is $6 \cdot 19$ tons per acre.

Lu Victoriathe area under potatoes for 1910-11 is practically the same as the preceding year, but the produce is 163,312 tons, as compared with I74,970 toms. This gives an abrrage yield per acre of $2 \cdot 60$ tons, so that notwiflastunding the prevalene of blight there is not a great difference in the averase vichl, owing to the splendid season for growth.

As regurds the loss incurred through any particnlar disease, it is not easy to determine, since there may be several present at the same time, but the potuto blight is so distinct in its effects that nore or less reliable estinates have lren made concerning it. In the Inited States, it is reckoned that there is an ammonl loss from the disease of $27,500,000$, and in New Zealand, for 1905 , if was estimated af nearly 2900,000 . When it is remembered that tomatoes have been found affecterf with the same blight in Victoria, New south Wales, and Quesnstand, it is evident how widespread the loss may become if prompt

In lietoria, it is a moderate estimate, derived foum my own observations, and those of the vibrons potate inspectors, that one hall of the crop, or 5o fere cout., was destroyed by the blight during 1910-11. The season was a

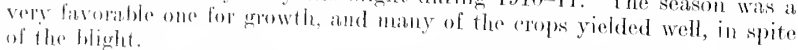

In the foflowing aceount of the diseases of the potato a full description has heon given of these which have aretually been found in the Commonwarlih. It is so costomety lor those who pose as anthorities on the subject lere to speak of disedses which have been found in America of elsewhere as

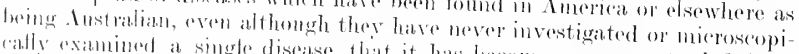
ciblly "xamined a simgle discase, that it has become mecessary to definitely trefine the discalses ald mally existing.

There is at widespreat ifesige on the part of growers to know more about the diseatses of the potate, for the innorane of the past ean no longer be tolorited, since there is a rigit system ol insperetion to prevent diseased tubers

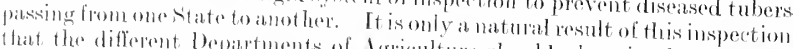
that the diflerent bepartments of Agriculture should place in the hands of growers the necessury informbetion and the most proctical methods for pre-

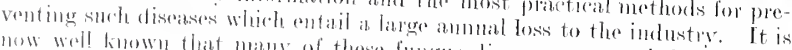

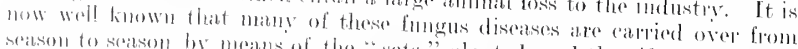

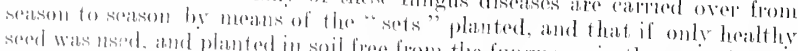

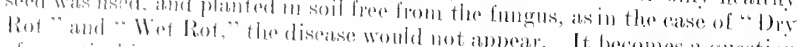

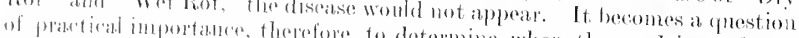

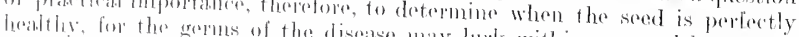

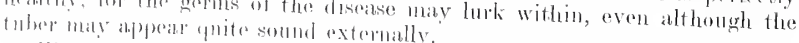

11 ( )

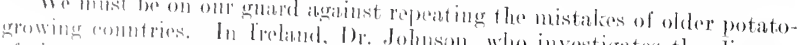

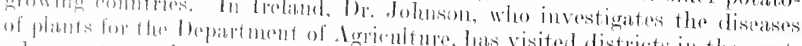
where polaters have followed potators fore howe visited districts in the west, serplently, disease is rampluth.

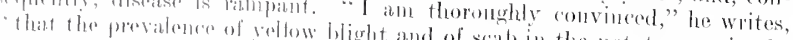
west. net to montion the ontinaty the and of sab in the potates crop in the West. net to mention the omtinaty labl-blight, is largely due to the planting 
of diseased seed. It is the exception to see healthy tubers. Nearly every tuber I have examined showed some sign of disease." And Count Arnim, in Germany, who is known as a skilled producer of potato varieties, and has a research laboratory on his property, in his pamphlet on Europe's Potato Industry in Danger, estimates the loss in Germany, in the potato crop for 1908 , through planting the diseased seed-tubers of 1907 , will be at least $£ 30,000,000$. 


\section{POTATA BLIUITT OR LATE BLIGHT. \\ (l'tyophthora infestans de Bary).}

\section{ILESTORICAL.}

This disease has been discovered in all the states of the Commonwealth, and was originally intcoluced in the seed potatoes. Just when it was first introlucel into the various states it is impossible to say, but it has been rrorded for New houth Wales as far back as 1846, the year after the severe ppiremic in Ireland of 1845. The ofiginal home of the potato is in South Anerica, whence it was brought to Europe in the sixteenth eentury, and this disease occurs on the wild form in thili. No doubt it has existed in the potato since its firt inteduction, and althongh the early accounts of it are rather obseure, yet in 1810 it was very prevalent in France and Germany. In 184t, it assmmed the charater of an epidemie in Canada and St. Helena, imd, in 1815 , the seriousoutheak oecurred which spread over Westem Europe and the United States. Berkeley, in his artiele entitled "Observations, Botanical and Physiologieal, on the Potato Hurrain," in the first volume of the fonernat of the Ilorlicultural society (1816), begins as follows:- "Few subjects have attracted more attention, or have been mole variously eanvassed, than the mould with which potatoes have been almost universal]y visiter (huring the antmmn of 18 t). The press has teemed with notices the mast contralictory; the attention of seientific men in every direction has been engaged by it; and three, at least, of the prineipal Govermments of Europe have issued rommissions to exmmine into its etiology, and to diseover, if possible, a remedy." Not only was it bad in 1845, but it inereased in 1846, then assumol a milder form in 1817 , and returized with greater virulence in 18IS. Beranse it was particularly bad in Ireland, where potatoes are so extensively grown, the disease received the name of Irish Blight, although in T'asmania at the present time it is generally known by farmers as "Brown Rust." The lattro mame, although expressive, is an unfortunate one, for the potato-grower in many cases car hasdy be convinced that this brown, dry dreary immediately beneath the slin of the potato (Fig. 2) has any connexion with the soft-rotting, foul-smelling symptoms which he invariably atsocedetes with the blight. Ifo is mot aware that the fungus of potato blight only produces this bown deray and prepares the way for seavengers, snch as hacteria, which extend the dacay thus set up, and give rise to the shushy rot and the disagreablo smell. Afrected potatoes are often quite firm when whes, but the sunken skin and the browning of the tissue immediately beneath, erencally indicate a tulser with the spawn of the fungus within.

(1) the of hem hand. I have had diseased potatoes just as had as anything I have seren in Iretand of soofland, and it is just becanse the conditions are not alway latromble in one drier climate to the development and spread of these ubiquitous hacteria that the final stages of deeay are not always remelexis.

It is interesting to reatl that in the noighbouring Dominion of New Zeritand thepe wats an outherak in 1893, but it was of such an apparently

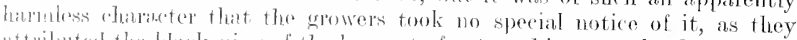
atfilnted the backining of the leaves to frost, and it was only eleven years

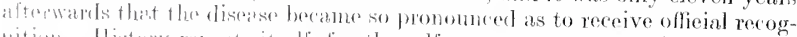
thifine. Ilistory repratis itsolf, lor the self-same reason was assigned for the

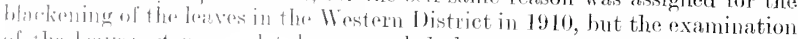

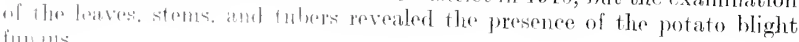


The recent history of the discovery of potato blight in the different states may now be given, but it is highly probable that it cxisted in Australia before 1909, although undetected. The already wide distribution of the disease in some cases, and the explicit statement of its occurrence in others, bear out this view. Thus, as far back as 1846, the vear after the terrible epidemic in Ireland, Joseph Phipps Townsend, in his "Rambles and Observations in New South Wales," dated October, 1848, remarks:- "Very fine black potatoes are also grown on the coast; but I observed in the local papers that the potato disease made its appearance in the colony in August, 1846." In Qucensland, too, Professor Shelton had determined it at least as early as 1892, for, in a Report issued by the British Board of Agriculture, in April, 1892, Queensland is the only Australian State in which the disease is mentioned, as follows:-- "Instances have occurred of Peronospora infestans affecting the haulm, but the effect on the crop being slight, necessitated no precautions or preventive steps being taken." So that, in two of the States at least, the disease was re-discovered, and probably also in the others, although there is no definite account of it.

In 1909, it was determined in each of the States, after an examination of the fungus producing it, and the order of its discovery in the respective States is here given. It was first discovered or announced in Queensland by the Government Entomologist and Vegetable Pathologist on 19th Mav; in Tasmania, on 19th July; in Victoria, 23rd July; in Sonth Australia, 29th July; in New South Wales, 11th August; and at Guildford, in Western Australia, on 31 st August.

\section{Symptoms of the Disease.}

The signs or symptoms of the disease may be seen either on the potatoplant above ground, or in the tubers underground. As soon as the leaves appear, they may begin to show signs of it. Instead of the green, liealthylooking leaf, the young leaves become pale in colour, and of a yellowishgreen. Then there may appear, generally towards the edges and tips of the leaves, irregular brown patches, or blotches, because the moisture collects and remains longer at these spots, and surrounding these, on the under surface, there is a delicate white mould just visible to the naked eyc. There may be brown patches due to other causes, but the white or ashygrey mould in addition, either on or around the decaying portions, is a sure sign of the blight. (Frontispiece).

More or less rapidly, according to the state of the weather, the blotches spread until the entire leaf may turn black and rotten, giving forth an offensive odour, or the leaf may simply show the brown blotches and wither up. If the weather is favorable, the disease spreads to the stems, which finally rot, like the leaves. This premature rotting of the green portions of tho potato-plants affects the growth of the tubers underground, if they are not already fully formed, and the disease may reach them, although some of th. tubers may remain sound, while others are affected. If diseased potatoss are examined, they usually show a depression of the skin here and there, and when cut across the flesh is brown, at first immediately beneath the skin, and this browning may extend more or less inward, as shown in Fig. 2.

The rot may not penetrate deeply at first, but ultimately the entire tuber may become a putrid, evil-smelling mass. Under the conditions of liest and moisture, which often prevail in Australia, the rot may not go beyond the brown stage at first, when it is known as "Brown Rust," and it is only whon 
this is followed up, by microbes or bacteria that soft rot sets in, and the offensive odour associated with the disease asserts itself. If the soil is comparatively dry, then the dry rot or "Brown Rust" results, but if wet, then the decay of the tubers is of the wet, soft, badly-smelling type.

\section{Relatex of the Fuygus to the Disease.}

It is so ingrained in the minds of many growers that the weather is the primary canse of this disease that it is necessary to convince them of the connexion between the fungus and the disease. In all the numerous determinations of this disease which it has been necessary for me to make, in order to settle the individual farms affected, I have invariably fonnd associated with it the same fungus, and this self-same fungus oceured wherever the disease was found, whether in Britain or America, New Zealand or Australia. But the relation of this fungus to the disease might be that of an alter-effect, the fungus following rather than causing the disease. To prove the latter, it will be necessary to produce the disease in liealthy potatoes by means of the fungus, and this has been done both by the spawn and spores inside the tuber, as well as by the spores on the ontside of it.

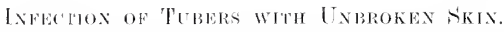

A tean, healthy (amman potato was kept moist, and snrounded with slices of a diseased potato. In sixteen days the disease appeared in the originally healthy potato by mere contact with the diseased, while similar "loan Camats potatoes, kept by themselves under similar conditions, showed IIo trace of it.

But it is mot necessary that there should be direct contact, for the eases containing the spores or propagating bodies may be carried through the air and porbere the same result. Some spores taken from the potato shown in the Plate I. were placed on the moist surface of a dean Carman potato and kept damp). It the end of sixteen days the clean potato was affected, and aven shewed tults of the lungus on the surface. Oassee has stated that he dial not succeed in infecting young tubers with spores, even when placed undere very favorable conditions for doing so, but I have had no difficulty in producing infection moder ordinary moist conditions, and the somndness of the petato to legein with, was placed beyond doubt.

\section{IXFGeTfox OH TIBERS WTH BROKEN SKIX.}

Potateres were also inferted beneath the skin, both with the mycelimm and spores. just as wonld happen when the shin was bruised from any eanse, and the disiase seon appesied. Clean potatoes were thes infereded with winute fragments of myelimm, about the size of a pin's head, at rarious foints, and similaty with spores, and the result was always the sameinfection took place, and the disease quickly spread. This mode of infertion was moch mores rertain than on the unbroken skin. is a typical cxample of a rean potater infected beneath the skin in several places by fresh sporangial, I will give the history of one which is represented in late xxxy, and the tulpor wats of at good sime lwoingsix inches in length. It was infeeted on 8th July, and, after

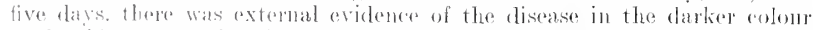

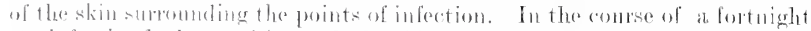
the infection hat spresal beneath the skin to the extent of an inele and a hall, and in there weeks the mutire surface of the potato was darker, and somewhat

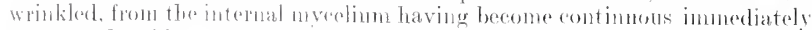

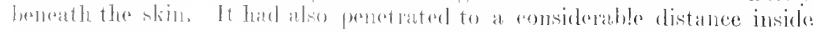


the tuber, so much so that on the twenty-second day after infection a slice cut lengthwise near the middle of the potato showed the browning of the tissue, as in Fig. 116. The potato was simply kept on a shelf in the laboratory, and even under these dry conditions the disease developed vigorously and rapidly.

It can be readily understood how clean potatoes in a pit, if infected by spores on the broken skin, from adjoining diseased potatoes, or by contact with the mycelium, would rapidly succumb to the disease.

Under moist conditions the sporangia were naturally formed on the surface of the potato, as seen in the Snowflake, picked up in the field, and represented 11 Fig. 1, as well as in several small boxes of potatoes sent over from Tasmania, treshly dug, and closely packed. It was not at all uncommon to find potatoes taken from damp soil with the fructification on the surface.

\section{Infection of Potato Tops only.}

Experiments were carried out to see the effect produced by infecting the tops or haulm of a growing healthy potato. A self-sown potato, when abont $e$ one foot high, was infected on 22 nd August with the spores of potato blight. The mode of infecting was by means of spores taken fresh from diseased potatoes, shaken up in a small phial of water, and a drop placed upon the centre shoots of the potato plant, as well as on the under surface of several leaves. Three days after infection, irregular dark green patches were observed where the drops had been placed. These patches rapidly became dark brown to black, and on mounting a scraping from these patches the fructification of the fungus was obtained in abundance.

The tips of the plant had now turned black and dry, although abundantly supplied with water, and the upper parts of the stem as well as the leaf-stalks were semi-transparent. A week afterwards, or ten days from the time of infection, several diseased patches appeared on the stem abont an inch from the ground, and also on the lower leaves, showing either that the mycelium of the fungus had travelled downwards, or that the falling spores from the upper leaves had spread the infection.

The disease now spread rapidly underground, and thirteen days after infection the entire portion of the plant above ground was black and rotten. On removing the soil, the underground portion of the stem, even to the very tip, was also seen to be quite black, soft, and rotten. The tubers were then removed, and appeared to be quite healthy, although few in mumber and small in size. They were kept in a closed jar for further olsservation, and on being carefully tested in March, 1911, showed no sign of disease. The eight tubers, varying in size from hazel nuts to walnuts, sprouted, and were planted in June, 1911. The healthy potatoes growing alongside remained quite clean.

This experiment shows that when infection begins in the "tops" the mycelium may pass down the stem, even to the underground portion, and although it did not reach the tubers in this particular instance, yet if left a little longer in the ground, it would in all probability have done so.

\section{Infection of Tubers only, From Planting Deseased "Siets."}

The general opinion held in other countries is that the spores reach the tubers through the soil after falling from the foliage. The foliage is first visibly affected with the blight, and generally the leaves are almost all destroyed before many tubers are found to be diseased. But low is the foliage infected? Some are candid enough to admit that it must come from diseased tubers at the begimning of the season, while others still rely upon some occult source. 
Wo have slown that tobers may bo infered by spores falling wpen them, but in a comparatively dry seibsul, areompanied by heat, the spotangia are not formed above gromid, and yot the tubens are diseased, showing that the mevelinm originating from in diseased "set" nust enter the tollors directly, withont laving invaled the portions above gromed.

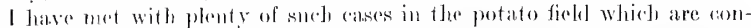
vineing enough to the actial observer, but potatose have been planted on the sorface of the gromed under straw, so as to seientifieally prove direct infection.

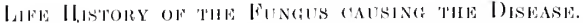

This misy be briefly given, and easily lollowed, by referring to the illustrafons taken from photographs. The lomgus is itsele a plant; or, as it is called, a parasite, becanse it preys upon the ford contained in the living potato-plant. We bave also to distinguish in the fungus, as in any of her plant, two primetpal parts the one which feeds and collects the nomrishment, and the other which propagates the lungus. The feeding portion is inside the leaf, stem, or tuber, and the lireding portion is on the outside, except in the ase of the fombato, where it may also be inside.

These two parts are seen in the sertion of diseased leaf slown in fig. 5. The mumeroms theads of the rungus inside the leal twist and turn anomg the cells of the plant, and form what is known as the spawn or myceliame, white the stender thesels on the under surface of the leaf bearing oval bodies, form the jrentification.

The mycelime causes the discolouration and death of the cedls with which it conces in contact, or into which it penetrates. In the leaves it produces the brown spots, and in the tubers, as sleown in Fig. 8, it surrounds the stareh-cells, drawing nourishment from the stareh contained in them, and, at the same time, cansing their clecaly and deatle. It probably also preys 11 pon the of her contents of the cells. If a small piece of the brown por-

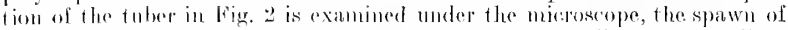
the fungus is seens spreateng in all directions among the cells. The nuyedium mas remabil topmant in the tissmes if the necessary heat and moisture are not supplied, but, msnatly, after it has cehansed the nomrisloment at a particular spot, it gives rise to the firestificitson. ()n the meder surface of the leaves it forms the downy monld (l'pontispiece), and tults of the sane mould appear on the surfice of the tuber, as shown in Fig. 1.

The fructifiation consists of long blanching theaks standing out from the surfice, and at the end of earh brimlle there is an egr-shaped body, which is known as a spore-case or sporangium, because it eontains the spores of the fomgos, which are equivalent to seeds as far as propagation is concermets.

This particubre fungus, howerer, does not rest content with producing one spore-case at the rend of earele branch, but it grows beyond this and produces another and still mother, until there are quite a number, as shown in lige 9.12, where each swelling on the branch indicates the spot from which a spore-cise has tallen. When if is realized that as many as nine sporeeases mat be probered on one branch, and that the portion of the leaf, shown

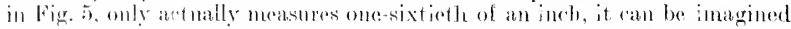
what myrialis of sporc-cases may be produced by a single potato-plant, and when it is known that the sporiugia are so small that it takes 800 or them end to end to measure an inche, it can be understood how readily they are blown about by the slightest beath of wind to neightouring potato-plants. 
If the plant is moist with dew or rain the contents of the detached spore-case break up into from six to twelve portions in a very short time, and each of these pieces squeezes out through an opcning at the top of the case and swims about on the moist leaf, or tuber, by means of two cilia, or swimming organs (Figs. 13, 15). After eight to ten minutes, or a quarter of an hour, these swimming spores settle down and soon begin to sprout, as shown in Fig. 16. The germ-tube is able to pierce the skin of the leaf or the potato, and once inside, this slender thread grows and multiplies at the expense of the food contained in the leaf or tuber, and soon causes the colls to turn brown, as in Fig. 2. Since the spawn of the fungus, under moist conditions, may produce spore-cases in fifteen hours, and in the case of the tomato in seven and one-third hours, is is ot to be wondered at that in moist, muggy weather the disease spreads from plant to plant with amazing rapidity. It will also be understood why moisture is necessary, for under dry conditions the swimming spores are not prodnced, and even if formed, if a dry spell came they would soon dry up and perish. Hence also the common notion that mist causes the disease. But cren if the amount of moisture is limited the fungus can still adapt itself to the situation. Under these conditions the spore-case does not divide into spores, but it sprouts direct, as shown in Fig. 17, and it can even play a waiting game, if necessary, for it may produce another body like itself, as in Fig. 19 (to right), ready to reproduce the fungus, if favorable conditions are not too long delayed.

Such is the wonderful life-history of this remarkable fungus, but how it survives from season to season remains still to be told.

In briefly recounting the life-history of this fungus, as made out by the microscope, and photographed, I have avoided technical terms as much as possible, but in doing so there is a danger of not being quite explicit, and this is more particularly the case in dealing with what is popularly called the fructification of the fungus. The oval bodies which produce the spores are known as sporangia, or spore-cases, and since the spores nove about in the water, like minute animals, they are generally called zoospores, or swarmspores. But in cortain cases, where there is not a plentiful supply of moisture, the bodies, which usually break up into spores, may germinate directly and penetrate the tissues of the potato. They are then known as conidia. The reproductive bodies are, therefore, either sporangia or conidia, but for convenience I often just speak of them as if there was but one essential element -the spore.

\section{Winterixg OF THE MYceltux.}

Since the spores are the only reproductive bodies known, and as they do not long retain their power of germination, succumbing very rapidly in dry weather, it is evident that there must be some other means of carrying over the fungus from season to season. In some of the fungi related to that which causes the potato blight, there is a winter or resting spore, which serves the purpose, but in the absence of that in this case, there is a substitute for it in the mycelium which winters in the seed. The widespread and simultaneous outbreaks of the disease can thus be readily accounted for, when it arises from the "seed " potatoes, and is only partially dependent on the spores bcing blown from plant to plant. The mycelium in the seed grows with the growth. of the plant, but only reaches extensive development in wet, muggy weather, such conditions being favorable for its development.

It is well known that in some seasons diseased potatoes may produce a fairly sound crop, because the conditions which enabled the potatoes to make good growth, were inimical to the excessive development of the mycelium in the tuber. A good illustration of this is given by Mr. Massee, in 
ronnexion with his experiments on the wintering mycehum. Tubers showing the rusty stains characteristic of the disease were sown in pots. They were grown in a cool, well-lighted, dry honse, and showed no trace of disease at the end of two months. One of the plants was removed to a warm house, and placed under a bell-jar, and it was killed by the fungus in nine dave. A fortnight later another ptant was removed to the same place, and within at week it was covered by the fungus. The third plant continued growing in the cool house for thirteen weeks, and there was no obvious disease about it, but of course it was latent there, ready to develop as soon as the eonditions were favorable.

It used to be considered, when the wintering of the mycelium in the tuber was not clearly recognised, that the spores were carried immense distances, because sudden outbreaks oceurred simultaneously over a wide area, but from what is now known concerning the nature of the spores, and the duration. of their life, the evidence is in favour of the spread of the disease over large areas through the tubers. Massee has stated this view in a very emphatic way :- Potato disease is now present in every part of the world where the potato is coltivated, and we have no hesitation in saying that the disease has been conveyed from one place to another by means of hybernating mycelium in the tubers, and not by means of spores."

I have just received, through the courtesy of Dr. Pethybridge, a verv suggestive paper read by him before the Royal Dublin Society, and published in March, 1911, entitled, "Considerations and Experiments on the Supposed Infection of the Potato (rop with the Blight Fungus (Phytophthora infestans) by Means of Mycelium derived dircetly from the Planted Tubers." He strongly opposes the theory of infection from a dormant mycelium in the seed potatoes, and, consequently, cannot aceount for the first appearance of the disease in the new season's crop. "In one fundamental point, in particular, we are still almost completely in the dark, and that is the manner in which the potato-plants first become infected each succeeding season." His opposition to this view, which is the most reasonable way of accounting for the fresh distribution of the disease each year, is based upon the supposed faret that discased tubers do not produce diseased plants. He gives a summary of what happens to discased tubers as follows:-

(1) They die before planting time;

(2) They die, if planted in ground, without produeing any overground stalks;

(3) They produce mall stalks above ground, which soon die, owing to direct infection with the fungus from the parent tuber;

(4) They produce healthy plants, which, provided there be no opportunity during the season of becoming infected by aeriallybome "spores," remain free from the disease.

This rasoning seemss to have all the cogency of a mathematical proposition, but, unfortunately, it does not take into account all the facts. The weakness of the whole position, to my mind, is this, that the behaviour of a few potatoes, healthy or cliseased, when planted in pots, is to be taken as an absolute, and not a relative, indication of what takes place in the field. The perint at issue is, whether diseased "sets" produce diseased crops or" not. If we take a broad and general view of the subject, without confining oldrelves to the results of a few pot experiments, there are some outstand:ng fact wonthy of consideration. First of all, if we ask ourselves the question, llow was the disease introduced into Australia, or, for that matter, into Ireland, from the original home of the potato? The only reasonable reply is, that it was introduced in the potato itself, by means of the spawn or nyccelium, which we know to be very tenacious of life. 
Then again, when a fair-sized plot of potatoes was planted with partiallydiseased tubers in virgin soil, in a locality surrounded by natural barriers, and far distant from any source of infection, the resulting crop was largely diseased, from 70 to 90 per cent. being affected, and not a single plant escaping. Now, even allowing for a considerable amount of infection from the spores produced on the field, the diseased tubers planted must have formed the starting point; and even Dr. Pethybridge himself has to admit that infection by means of diseased tubers does occur, althongh he minimizes it as much as possible, for he says, "If we except the few diseased plants from diseased tubers, which do undoubtedly occasionally occur, but which can scarcely be regarded as being part of the genera! crop."

We have opportunities in Australia of planting potatoes for the first time in districts quite isolated from any outside sources of infection, and yet the disease occurs there. No amount of specia! pleading can get over the origination of the disease from the tuber, and so William G. Smith philosophically, if not scientifically, winds up his consideration of this disease by saying, "How the disease reaches the green tops of next season's crop is not clearly known, but it must come from diseased tubers.'

I had a splendid illustration of this in Gippsland, where a grower planted seven acres of potatoes for the first time in virgin land, and far removed from any other potato-growing centres, having secured his seed from a district reputed to be free from blight. The plants grew healthily, but, after flowering, the tops and tubers became badly affected. I was so convinced, from the surroundings, that the disease had been carried in the seed potatoes, that I asked the name of the grower in a distant part of Victoria who had supplied the seed, and, on visiting that particular farm, the disease was found there, atthough that particular district had hitherto been considered clean.

Every potato planted does not require to be diseased in order to explain the general spread of the blight, for once the disease has started in a paddock, the spores are readily carried by the wind to neighbouring plants, until the whole field is soon involved.

Further, it is hardly realized how long the mycelium may remain dormant and still infect the tubers when favorable conditions arise. I had some specimens of diseased potatoes sent from Killarney, Victoria, on 24 th October, 1910 , and there was no doubt of their being infected, for the fructification of the Irish Blight fungus actually appeared on the surface of the roung tubers. One of these was immediately placed under a bell-jar, and at the end of four months (24th February, 1911) it had become dry and shrivelled, and quite hard. The potato was certainly as dead as a mummy, but a small portion of it was inserted beneath the skin of a perfectly healthy Carman No. 1 potato, which was placed under a bell-jar, and not even kept moist. A similar healthy Carman potato was kept as a check, under the same conditions, and no sign of disease appeared in it. The disease soon began to show itself in the infected potato, starting from the point of infection, and at the end of May, the entire potato had become diseased. That this disease was Irish Blight was not only evident from the appearance, but a slice taken and kept moist under a bell-jar developed the fructification in forty hours. Dr. Pethybridge asks, "How could Phytophthora, if present internally, have succeeded in carrying on an existence for over three months without exhibiting some signs of its presence?" Here is an actual case where the mycelium remained in the tuber without showing any signs of its existence, and yet, at the end of lour months, it was capable of infecting a healthy potato.

The pot experiments carried out by Dr. Pethybridge were on similar lines to those of Massee, with the addition of control plants, but the results were diametrically opposite: Out of three healthy "sets" planted in 
pots, and plaral in a warm greenhouse, all grew, and remaned perfectly healthy, while of three diseasnd "sets," similarly treated, one rotted away, and the two others podued perfectly healthy plants. Again, out of nine healthy "sets" planted in pots, and placed in a eool greenhonse, all grew at first and produmed fealthy phats, but ultimately the blight appeared on all the plants but one. Which remained healthy. ()f nine diseased "sets," Jlanted like the preceling, theree completely rotted in the soil, and all the rest of the ghants. with the exception of one, became discased.

The two hat lhy plattis. me derived from a healthy and the other from a diseased "set," were placed in the warm greenhouse, and coverel with a bell-jur, hut un signs of blicht appeared on them. "The result of my experiment." as statad by Pr. Pothybridege, " is in agreement with those of many previons workes, which are in the main to the effect that tubers affected with Phylophlenel prodere healthy plants." But for an explanation of the infection of thr hualthy plants it is necessary to assume its oligin from a diseased "sot." ". Mthough absohite proof is lacking, it seens practieally cretain that the plants whose foliage bacame discased must have become infectod by means of sposes from the single diseased sprout sent above ground by one of the diveased "rets."

That the rasults should be lifferent in a few pot experiments is not to be woudered at, but whenever field experiments are undertaken with diseased "sets," and the weather favolable, the produee is invariably diseased.

The objections raised to the infertion of potato plants at the beginning of the satson hy the mycelium or spawn of the fungus may be briefly stated alld answrered.

1. How conlel the internal mycelium pass from the tuber through the stable to the leaves and remain dormant for months, without exhibiting some signs of its presperce?

In this rase tle rapidly-growing potato-plant is able to provide for the wants of the fungus, as well as its own, but when flowering time eomes along, and this is the usuat priond when the fouctification of the fungus begins fo appear on the leares, then the mutritive material is required for its own mads, lout the fungus steps in, appropriating the nourishment, and asserts itself by producine it fructifications, and more or less rapidly destroying the various portions of the phant.

2. II is a dormant intermal myeclimm ?

This is generally considered to be an insuperable objeetion to the idea of infoction of the plant by means of a disensed "set," and no doubt it seems at lirst sight at great stmmbling-block in the aeeeptance of this view, but, rightly understoud, ] fonsider it to be the strongest argument in its fibvour. 1). Potteglicige writes: - "If this theory [dormant internal myeelium] is cortect, it semes almest impossible to explain the undeniably beneficial cosults anceruing fom spraying the crope with Bordeaux or Burgundy mixtowe." Tt is the oloject of spraying to save the plant from infection, and if the fungus late alreaty gatined an entrance into the tissues, it is beyond the restede of eprotying.

But it is woll komon that the lesults of spraying are very variahle, and, in my ofrinion. the variable lesults obtainel from spraying are largely due ter the twe different nexdes of infertion. If a large proportion of the plants

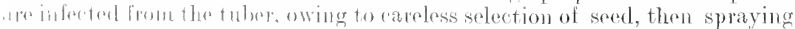
will not have much offort, but if the infection is due to wind-borne spores, then. if spraying is dome at the right time, be fore the blight has attacked the

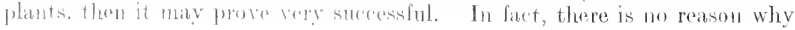


it should not be completely successful, if it has simply to protert the plant against wind-borne spores, and my contention is that it is brcause the tungus is inside, derived from the tuber, that spraying is sometimes attended with poor results. For success in spraying a careful selection of seed is a great help. Any one who has studied the blight in the field must have noticed, in its carly stages, how it often ocenrs in patches, although it may soon become continnous, and in these patches you can sometimes tell the very plant from which it spread. A very striking case was brought under my notice. There was a patch in the paddock wherc the disease was specially bad, and, on examining that patch, there was one plant, towards the centre, much more collapsed and decayed than the others. On digging it up, it was found that the four or five good-sized tubers were badly diseased, while the tubers of surrounding plants were still apparently healthy. The one plant had been infected from the "seed," and the spores had been carried from this as a centre to neighbouring plants.

3. Why are the tubers infected by falling spores from the leaf, and not by the internal mycelium passing along the underground branches and attacking the new crop?

As a matter of fact, the new tubers are infected in both ways, and the diseased area may be found spreading from the stalk end or from any portion of the surface at first, and always immediately beneath the skin. I have traced the entrance of the mycelium through the stalk to the young tuber, and I am endcavouring to demonstrate, in a practical fashion, that this is the way in which each tuber is infected when spores falling from the leaf are excluded.

To settle the question of direct infection of the tubers from the parent plant by the mycelium, I have planted some diseased potatoes on the surface of the soil under straw. The object is to watch the tubers while growing, and see if the mycelium passes direct to them.

The soil is reduced to a fine tilth, and the diseased potatoes are planted firmly in the ground until half covered, then a coating of straw, about one foot deep, is placed over them.

4. "Another strong argument against the acceptance of this theory is that, according to it, the attack of the stalks must proceed from below npwards, whereas the exact contrary is what is actually found to take place in the field."

What takes place in the field is this, based upon an examination of the young shoots and tubers at different stages of growth. When the tuber is planted, and the heat and moisture favorable to it, it begins to sprout, and the mycelium also becomes active, growing into the shoot, as indicated by the presence of the mycelium there. Then the fungus may grow so luxuriantly, if the weather is moist and muggy, which renders the young tissues of the potato exceedingly soft, that it completely overcomes the young potato plant, and causes it to die down. But the young plant may be sufficiently robust to continue growing, and prevent the fungus gaining the mastery. This may go on until the flowering period is reached, and since it is in the leaves or succulent upper branches that the supplies of food are first exhausted by the fungus, it is there that the fructification first appears. It will be evident that the fungus naturally grows upward, but that is very different from saying that any external sign of its presence must be shown at the base of the stalk.

5. "Perhaps the most serious obstacle against accepting this dormant mycelium theory lies in the fact that, if it is to be used to explain epidemics in the manner suggested, it is almost impossible to get away from the suggestion that practically every potato which is planted is diseased with Phytophthora to start with." 
This serious obstacle need not stand in the way of the acceptance of this theory, for it must be remembered that starting-points are all that are required, and when once a pla't has prodnced its spores on every leaf, there is abundance to be carried by the wind to infect a large portion of the field. The spores on the under, and sometimes on the upper, surface of the leaf are seen with a magnifying glass as millions of particles of hoar-frost, glistening and perpetually oscillating, so that the slightest breath of wind detaches them, and if they reach a neighbouring leaf or stalk they are sure to stick, from their adhesive nature.

There are still points to be settled in connexion with the hife-history of the Irish Blight fungms, but I do not consider that infection, by means of the intermat mreclimm, is on eof them, since the mycelinm has been proved to cater the yonig sprout, and also the young tuber, growing laterally or terminally on an underground branch, or rhizome, or stolon, as it is sometimes malled.

\section{Persistence of Vitality in the Mycelly.}

The statement is usually made in a general way that the mycelimm retains its vitatity as long as the potato which harbours it, but it may even persist when the tuber has become quite hard and dried up like a piece of wood. This was strikingly illustrated by means of an infection experinent. A discibed potilo, dug on 21th october, 1910, was kept on a shelf where it herame perfectly dry, shrivelled up and quite hard. A small portion from. the interior, in the form of dust, was inserted beneath the skin of a perfectly hwithy Carman No. I. Which was placed under a bell-jar on 24 th February, 1911, and not even kept moist. A similar healthy Carman was kept under a bell-jar, exactly under the same conditions, but without being infected.

In the infected potato the disease soon began to show itself, starting from the point of infertion. When examined, about the beginning of May, the jotato was inite fim, but the disease had extended over fully three-fourths of the surface, and three apparently healthy shoots were produced at the crown end. By the end of May, the three green shoots had been invaded by the fungus and killed, while the entire surface had become brown and turning solt in parts. On making a longitudinal section in the middle of the diseased potato, the interior was brown and hollow in the centre, the only seemingly linatly portion bring a little narrow strip beneath the skin at the crown enil.

The one hatf was replaeed under the bell-jar, and the other half kept in a moist chamber. The latter in 40 hours produced the fractification of the fungus on the apparently sound and firm portion of the potato at the (rown end, while the latter developed sporangia in the corresponding portion in the contse of five days. 'The potato kept as a check jemained perfectly sollint.

This simple experiment has an important bearing on the vexed question ats to how the disease starts afresh each season, when the wather conditions are favopable. The mycelimm may be carried over, as we have seen, in the seed potatoos, but it may also persist in the dried up and mummified diseased jestitomes.

Whon such at tuber is placed in a moist chamber, there is no development al the functifuation of the fungus, hroause the tissues are all dead; but when it is broken nj, and at sma!l portion placed beneath the skin of a healthy putho, then the morelinm leagins to srow. The mycelium is still alive in the doad potato, hut it reguires the stimulus of the living tissue to change it from the dormant to the active condition. This is well shown in the inferted fulrap, where the mycolimm hat invaded and destroyed all the tissme, with ile oxerption of a marrow strip towards the crown end. Where the tissue 
still remained alive, there and there only the mycelium was able to develop further, under the influence of moisture, and produce the fructification of the fungus. Such tubers in the field coming in contact with the cut surface of a healthy potato could infect it.

Not only may the mycelium remain dormant in the tubers, it may also persist in the shrivelled-up tops. The old haulms are isually left on the field and ploughed in, so that when potatoes are planted in succession, there is no difficulty in accounting for fresh outbreaks of the disease.

\section{Summary of Views on Infecton by Dormant Mrcelium.}

It is a recognised fact that the spawn or mycelium of the fungus can live over the winter in the diseased tubers, and remain dormant until the necessary conditions of heat and moisture start it into new life. This life may manifest itself at least in three ways, and each of them may serve to start the blight afresh.

1. A diseased potato lying on the surface of the soil can produce plenty of spores, as shown in Fig. I, and these spores may be carried to and infect healthy potato plants. Ol it can prodice spores even in the soil, and these may be carried to the surface by insects, worms, or otherwise.

2. When diseased potatoes are planted, however, the dormant mycelium may not directly produce spores, but grow up into the stalks and foliage, where the spores are produced, as shown in the Frontispiece.

Over half an acre was planted with diseased tubers, so badly infected that they had been sent to the destructor, and I saved them for purposes of experiment. They were grown on virgin soil, isolated from any other potato crop, and, just about the flowering stage, they showed signs of the disease on the foliage.

3. The dormant mycelium may even pass directly into the new tubers from the diseased "sets," without the production of spores above ground. Cases have occurred where diseased "sets" were planted in a garden, and while the linxuriant foliage was perfectly healthy, the new tubers were diseased. The best proof that this takes place is shown in the common oceurrence of infection from the stalk end, as in Fig. 2; but potatoes are being grown under straw, and under old rotted sacks, to afford further ocular demonstration of the fact that the mycelium can pass directly into the tubers.

\section{Principal Modes of Infection.}

In discussing how this disease is spread thronghout the crop, and how it is introduced into new districts where potatoes are grown for the first time, it is necessary to come to an understanding on one or two points. Those growers who consider that it is entirely a matter of the weather may be left severely alone, but for the large body of producers, who desire to know the real nature of this disease, and are willing to adopt measures for its prevention, there are certain facts worthy of consideration.

First, the disease is caused by a fungus known as Phytophthora infestans, for not only is this particular fungus always found associated with the disease, but the disease may be produced in perfectly healthy plants or tubers by inoculation with the fungus.

Second, the disease was introduced into Australia with the potato, and the only known means whereby this could be done was by the spawn, or mycelium, of the fungus inside the tubers. That the sporangia should retain their vitality for a considerable period has in no case been observed, but the mycelium is capable of infection, even after the potato containing it is quite dry and hard. Starting from these two established facts, that the disease is due to a fungus, and that it may be carried in the seed potatoes, let us now see how the disease is spread in a general way. 
When a disased potato is planted and sprouting commences, the myeelium may enter the young shoot and grow inside, keeping pace with the elongating stem, just as in the smut of coreals. It passes from the stem into the leaves, and sooner of later, accorling to the humidity and heat, reproductive bodies wre profuced on both stem and leaf. The spores falling to the ground, and learhing the tubors when moist will infect them. and produce the disease as alreaty shown. But this will hardly account for every one of the young thbers being affected, even when not in contact, as in Fig. 110.

A reitr distinction must. however, be drawn between the two different modes of infection - by the murelium arising from the "seed," or by the spores falling from the loaves - since this has an important bearing on the way in which the fungus rearthes the tubers. When infection of the potato plant abowe ground oceurs by means of spores, carried by the wind or other agency, then the mycolium produced may descend the stem, until it has reached its furthest end, and thou pass along the underground branches into the tuber's.

Bnt when the infection of the plant is due to the mycelium inside the seed potato, growing mp in the young shoot and extending to the leaves, then cven althomgh spores are not formed, owing to the dryness of the atmosphere or excessive heat, the aseending mycelium may pass into the underground branchrsand infect the tubers. Although the view is commonly held that the mycelimm asconding the stom from a diseased tuber reaches the leaves, and then passes down the stom to infect the tubers, there is no evident necessity for this round-about method. It is only when the tops are infected by windborne spores that the mycelium will pass down the stem and enter the tubers.

\section{RESTNG FHORES}

The principal known mothods by which potatoes beeme infected have just been given, Int there is a suspicion in many minds that there is something in the soi] where potatoes have been grown, which may produce infection in otherwise healthy potatoes. This raises the question of resting spores, or asperes being developed underground by the fungns, and remaining dormant in the soil for several seasoms. In fungi, closely related to the one which prodnces the potato disease, bodies are formed which are able to remain dormant in the sill and reproduce the fungus when the growing semsen again comes round. But in $P$. infestans no such bodies have ever bean conclusively proved to exist, and besides, potatoes grown in pots. where discased potatoes had heen produced, did not eontraet the disease, This particular fungus produces a hibernating mycelinm in the tuber, and fiulging by the widespread distribution of the fungus, it is thereby provided with a much mone efficient moans of propagation, even nuder adverse conditions, than wonld bo possible even with resting spores. (Note-p. 100).

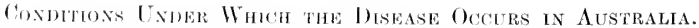

The discorery of the Irish blight in Anstralia has bronght into prominence the fact that, while the same fungus-Phytophthore infestans - is invariably prosent, it has not always the same apparent effect upon the potato plant, as in comntries such as Ireland, where the conditions are so different. So promentrees is the difference that many of the growers, particularly those who lat re lish experience of the llisease, lefuse to believe that it is the same, and stontly mintain that it is a case of mistaken identity. They assert that these is not the sudden deray and blackening of the tops, with the offensive

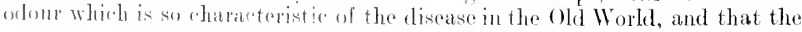


tubers themselves do not at once rot away in to an evil-smelling putrid mass. I have earefully inspeeted the potato fields in an entire distriet where the disease appeared the previous season, and failed to diseover any deeisive symptoms of the disease above ground, but on digging up the tubers, the sunken skin, and the rusty-brown markings immediately beneath it, at onee revealed the presenee of the fungus, which invariably developed the charaeteristic fruetifieation when kept for a short time under moist conditions. In the great majority of eases it was in the tubers that the disease was definitely proved, although in an exceptionally wet spring like the present (1910), and an equally wet autumn (1911), accompanied by hot muggy weather, the stalks and leaves freely developed the spores, and beeame black, rotten, and odorous.

The attitude of many of tha growers not only in one, but in all the States, is strikingly indicated in the following quotation from a letter received from Mr. George Quinn, of the Agrieultural Department, of South Australia:"There is the usual sceptieism exhibited liere respeeting the identity of the disease. Because the crops do not collapse into a rotten, filthy-smelling mass in a few days, the folks, particularly from Ireland, declare it is not Irish Blight. Most of the grower's near Adelaide showed their faith in this fallacy to the extent of planting clean seed on land where the erops went down, and were ploughed under last year. Result-crops planted before September this year on such land gone down completely, and the decided opinions are not quite so loud-voiced against the "man with the microscope."

While it is generally the ease that the tubers affected with the disease, when dug, are quite firm and hard, this only shows that the distribution of the heat and moisture must be taken into account, as well as the llature of the fungus. The dry and hot weather which often prevails while the potatoes are growing, tends to check the development of spores, and to mitigate the severity of the attack. In some districts, for instance, the main crop is planted in June, July, and August, which are our winter months, and sometimes there are heavy rains in July, August, and September, so that there is excessive moisture in the early stages of growth, and sufficient heat to encourage the fungus, which is partieularly prolific in sheltered hollows. In such districts the growers have now learned by experience to plant late in order to avoid the disease, that is, about the beginning of September, or early in spring. In other distriets the very reverse is the case, for at Fish Creek, in South. Gippsland, where the disease was first diseovered in Victoria, the erop was planted late towards the end of November, and dug in June and July. In the month of June there were $8 \cdot 76$ inehes of rain, and sufficient heat to eause the fungus to develop freely. The early erop may eseape the disease, while the late crop suecumbs, or vice versâ, and similar eonditions to those prevailing in Australia have been observed at the Cape, by Lounsbury, who writes in his Annual Report for 1909 :- "The influence of humidity on this disease is very marked. In the eastem districts it is a summer and fall trouble, while in the south-western districts it is a late winter and spring one. Excepting you'ng ones, few potato patches around Cape Town were free from it in October; but in November, when the dry south-east wind began to blow, it disappeared as if by magie."

No general rule ean be laid down in our variable elimate, for eloudy, damp, and sufficiently hot weather may oeeur in the winter months to develop the fungus, or similar eonditions may prevail in the spring and autumn.

In Western Australia, the disease was first diseovered on 31st August, 1909 , and from this onwards through the spring months of September, October, and November, the area affeeted rapidly extended. It was noted that the 
spring of that year was an exceptionally protracted one, the rain eontinued even until the end of November. When the wamer and drier summer weather set in, the rapid spread of the disease was checked, and from the end of December up to the present, no further outbreaks of the disease has been officially recorded. The great heat around Perth extending to the soil had evidently killed the bhight, root and branch, and unless imported in fresh seed, there is no reason why that particular locality should not remain free.

The blight mav appear early in the tips of the main shoot, even when the plant is just above the ground, or about three inches high, and the influenee of moisture on the development of the disease is very evident where irrigation is employed. In South Australia, the crops are mainly grown during summer, with the help of irrigation, and some which have been attacked gradually dry down. If these are not watered when first beginning to deeline, the tubers, though small, do not appear to decay, but it water is applied to stimulate the flagging growth, the tubers either rot straight away or do not keep lorg. The heat is sometimes so intense that the soil becomes so hot that one eamnot bear his hand upon it, and in Adelaide the thermometer has registered as high as 180 degrees Fahr. in the sun.

It has already been recorded that tomatoes are readily infected by spores from the potato, and vice versâ, and the praetice adopted in some districts of planting tomatoes while the potatoes are growing is not to be recommended. The blight has been found on them in June and July, and the spores might be easily transferred to the early-planted potato crops, just at a time when they are most susceptible.

While the blight has been hitherto most serious with us in districts with a heavy annual rainfall, it is not so much the total amount of rain as the time when it falls that determines the development of the fungus. It may be prevalent in the early crops, which have received the winter rains at the start, and as they are usually grown in sheltered spots, to protect them from frost, they sometimes suffer severely. Or it may be very bad in the late crops, which have received the autumn rains towards the end of their growth, when the fully-formed and mature tubers suffer less than those that are soft and immature.

\section{Relative Frequexcy of Potato Blight is Victoria during the Dhfferent Months,}

This disease was first discovered in Victoria in July, 1909, at Fish Creek, but there is little doubt that it existed elsewhere in the State, although unobserved, and that this was not its first appearance. Then, in September, it was discovered at Welshpool, and in November, at Beech Forest, and this was the entire record for 1909.

In 1910, no specimens were received until Mav, although suspieious-looking potatoes had been examined before that without result. It was then discovered at Foster, not far from Fish Creek, and in every suceeding month specimens were forwarted. In () tober, the number of specimens received was the wreatest on record up to date, chiefly owing to the outbreak in the Warrnambool and Port Fairy districts. During the early months of 1911 the wather conditions were exceptionally favorable, and there was a considerable extension of the disease to different districts. The deseription of the weather about the middle of Mareh by the Commonwealth Meteorologist was a comhination of ronditions simply perfert for the spread of blight- "Generally warm and sultry, with scattered rains and thunderstorms." Many of the (rops, too, had just finthed flowering, and they were at a most susceptible stagis. 
The following table will show the number of blighted specimens of Victorian-grown potatoes received monthly from the date of the first discovery of the disease, and it affords a rough indication of its relative frequency :-

Table II.-Number of Spechens of Potato Blight determined EACH Moxth.

\begin{tabular}{|c|c|c|c|c|c|c|c|c|}
\hline & & & & & & $\begin{array}{c}1909 \\
\text { Specimens. }\end{array}$ & $\begin{array}{c}1910 \\
\text { Specimens. }\end{array}$ & $\begin{array}{c}1911 \\
\text { Specimens. }\end{array}$ \\
\hline January & . & . & .. & . & . & $\cdots$ & $\ldots$ & 25 \\
\hline February & $\ldots$ & $\ldots$ & . & . & $\ldots$ & $\ldots$ & $\ldots$ & 22 \\
\hline March & . & . & . & . & $\ldots$ & . & . & 107 \\
\hline April & $\ldots$ & . & $\ldots$ & .. & $\cdots$ & . & $\because$ & . \\
\hline May & . & $\ldots$ & . & . & $\ldots$ & . & 3 & .. \\
\hline June & . . & . . & . & . & $\ldots$ & $\ldots$ & 4 & $\ldots$ \\
\hline July & . & .. & . & . & $\cdots$ & 1 & 7 & $\ldots$ \\
\hline August & . & . & . & $\ldots$ & $\ldots$ & . & 4 & . \\
\hline September & . & . . & . & . & $\ldots$ & 2 & 8 & . \\
\hline October & $\ldots$ & .. & . & . & $\ldots$ & . & 26 & . \\
\hline November & $\ldots$ & . & . & . & $\ldots$ & 3 & 10 & . \\
\hline December & & $\ldots$ & . & . & .. & $\ldots$ & 9 & . \\
\hline
\end{tabular}

Up to the end of March, 1911, the practice of quarantining parishes in which the blight occurred was followed, in order to protect the clean districts, but it was then found that the whole of the potato-growing districts of Victoria were practically infected, and the practice was consequently discontinued, as serving no useful purpose.

\section{Distribution in Relation to Rainfall.}

It is well known that, while a certain amount of humidity is necessary for the development of the fungus causing the disease, it does not follow that it will only flourish in districts with a heavy annual rainfall. It is more the distribution of the rainfall throughout the year than its actual amount which determines the prevalence of the blight. The disease has now been discovered in all the potato-growing districts of the State. At first the disease was only recognised along the coastal districts, then it extended inland to the plains and tablelands, until now it is found at Bullarto $(2,452$ feet), the highest potato-growing district in Victoria, as well as at sea-level.

I am indebted to Mr. Hunt, the Commonwealth Meteorologist, for a summary of the weather conditions in Victoria during the first quarter of 1911, when the epidemic had become general all over the State (Appendix I.) The state of the weather recalls that of the great epidemic in Ireland in 1845. During the quarter "the heaviest rainfall was in Southern and Eastern Gippsland, Murrungowar, about 15 miles north-east of Orbost, recording no less than $32 \frac{1}{2}$ inches, and Balook, a place 13 or 14 miles north of Alberton, 303 inches."

The month of March was also very wet. "In the north the average was exceeded by about 30 per cent, but south of the Dividing Range two to three times the normal amount fell. The greatest excesses were in Central South, and Gippsland, several stations in both areas receiving more than three times the average amount."

As showing how favorable the first quarter of 1911 was for the spread of the blight, as far as moisture was concerned, the rainfall is given at Melbourne, as a centre, at Yackandandah and Tallangatta, in the North-East, 195 and 212 miles inland from Melbourne respectively, and at Beech Forest, in the south, in the direction of Cape Otway, in all of which the blight was found. 
Table III.-Rainfall for Frrst Quarter, 1911.

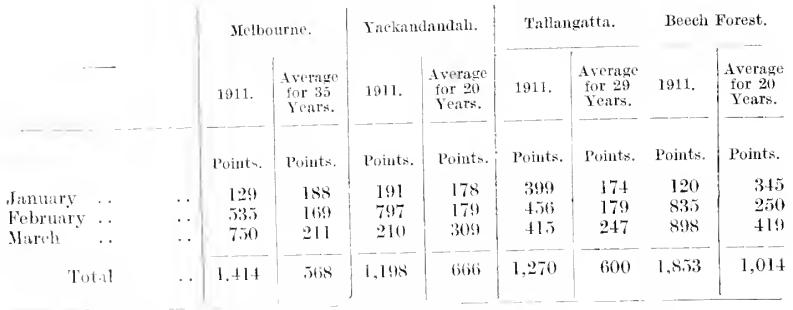

TOMATOES AXI IRISH BLIGHT.

The tomato is so closely related to the potato-plant, as I have shown in the Journal of the Department for April, 1910, that potatoes and tomatoes may be produced on the same plant. A tomato shoot may be grafted on to a potato hauhn, and there will be tomatoes above gromd and potatoes nuder ground. Conversely, if a potato stem is grafted on to a tomato shoot there will be only tuber's borne in the axils of the leaves.

It was to be expected. therefore, that sooner or later, as in other parts of the wortd, the clisease of Irish Blight would be found attacking the tomato crop in lustralia. It has already been found in tomatoes imported into Victoria from New Sonth Wales, as recorded in the Journal for January, 1910, also in Queensland, as noted in the Annual Report, 1909-10, but I have just fouml it (April, 1911) for the first time on plants grown in Vietoria.

1 row of tomatoes, containing abont 150 vines, was planted alongside potatoes in the Yannathan district, the seed potatoes and the young tomatoplants being planted at the same time, on 27 th December, 1910. About 11th Wareh, the potato-tops began to show signs of disease, and in about a week they all went down with Irish Blight. A few days after the potatoplants hat succumbed, the disease was noticed in the tomatoes, when the fruit was forming. When I examined the plot, on 6th April, not a single plant had escapesl, and only an oceasional ripe and healthy tomato could be fomd, and it was evident that the tomatoes had been infeeted from the adjoining potatoes. The tomato-plants were still green and flowering, but the lower laves were often brownish and withered. A careful examination only revealed the presence of Early Blight on the leaves, so that, although the fungus of Irish Blight may appear on the leaves and stems of the tomatoplant, just as in the case of the potato, it only affected the fruits at this stage. The fruits were the first portions of the plant to be attacked by the wind-borne spores.

Tomatoes were found affected at all stages of growth, from the tiny fruit, not the size of a pea, to the full-grown and large-sized, lobed fruit. There is a brownish discolouration at first in patches, with a tendency to becomp mottled, and when the fruit is sliced, this is seen to be due to the discolouration of the pulp extending more or less throughont.

kx]eriments were carried ont to show that healthy tomatoes can be infected from discased potatoes, and healthy potatoes from diseased tomatoes, with the lollowing results:-

1. A healthy green tomato had spores from a diseased potato plaeed on its skin, in a drop of water. In course of time, the surface around this spot becann discoloured and depressed, and in sixteen dars the fractification of the fungus was produced. 
2. A healthy potato, of the Southern Cross variety, was infected at the crown end with spores from a diseased tomato. In six and three-quarter days the tructification of the fungus appeared in various patches, and the young green shoots of the potato were literally covered at the base with the fungus.

3. A clean tomato was placed in a vessel where a diseased tomato had been freely shedding its spores, and from mere contact with the spores the healthy tomato was infected, so much so, that in nine days the fructification appeared on the surface.

In every case of infection there was a control experiment, in which similar healthy potatoes or tomatoes were kept under exactly the same conditions, but without the fungus, and no blight appeared. So that it has been conclusively proved, while the weather conditions may favour or hinder the development of the disease, it camnot be produced without the fungus.

After the discovery of blighted tomatoes in Victoria plenty of fresh spores were available, and an experiment was carried out to test the mutual infection of spores from potato and tomato under exactly similar conditions, when applied to the mbroken and broken skin. In each case there was only a single point of infection, and each specimen was placed by itself in a closed jar, lined with moist blotting-paper, on 10th April, 1911.

\section{Table IV.-Mutual Ixfection of Apores from Potato and}

ToMato.

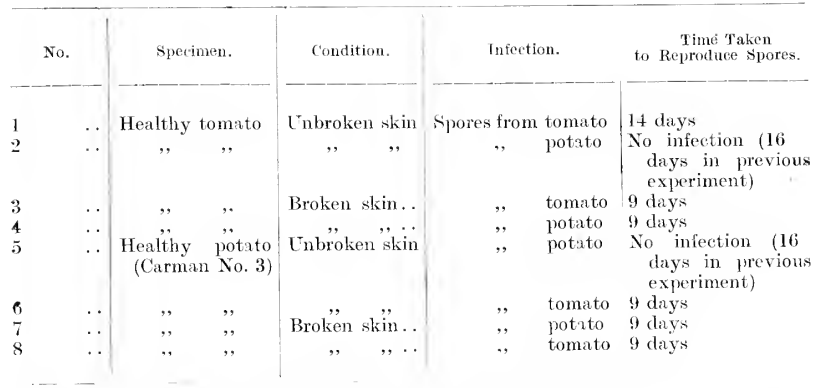

One of the healthy tomatoes and potatoes was kept separately, under moist conditions, without any development of disease.

In nine days two of the tomatoes and two of the potatoes with broken skin, as well as one of the potatoes with unbroken skin, produced the fructification of the Irish Blight fungus. At the end of fourteen days a tomato with unbroken skin also produced the fructification, but no further developments were observed at the end of a month, and the experiment was considered closed.

Thus, a tomato and a potato with unbroken skin, inoculated with spores from a potato, were not infected, owing to some individual peculiarity, but in a previous experiment this infection was successtul, and the fructification of the fungus appeared in both instances in sixteen days.

Appended is a short account of the behaviour of each specimen.

No. 1 showed a depressed area of about three-quarters of an inch on the third day, and on the fourteenth day this had increased to fully 1 inch in diameter, but without any noticeable discolouration, and on the margin a 
few tufts of the fruetifieation appeared. At the end of the experiment the tomato beeame soft and rotten, and the diseased patch was overgrown with fusarium.

No. 2 was still firm, and showed no trace of disease.

No. 3 slowed a small depressed area at infection point in three days, and on the ninth day, the stightly-diseoloured and softened arca was about $1_{2}^{1}$ inches in circumferenee, and distinetly marked off from the sound tissue. Tufts of sporangia had burst through the skin over the diseoloured area, and even beyond it. At the end, the sprcimon was completely rotten.

No. 4 was similar to the preceding, and the origin of the spores from the potato did not seem to affect the result. It was completaly rotten, and eovered with a thiek felt of fusarium.

No. 5. The potato remained quite firm, and free from disease.

No. 6. There was no sign of infection on the third day, but on the ninch day there was slight diseolouration over a cirenlar area of about half an inen in diameter, and tufts of sporangia were seen bursting through the lenticels, even bayond the discoloured portion. At the end, the entire potato was invaded by the fungus, and tufts of sporangia were produced all over the surface.

No. 7. This specimen showed discolouration on the ninth day over an area of about 2 inehes in diameter, and the fructification had burst through, over, and byyond this. At the end, the infection had extended over threefourths of the area of the potato, and there were two strong apparently healthy shoots and a few smaller ones at the erown end. This was considered a very suitable sample for testing the assertion that the produce of a diseased tubar is not discased, and it has ben planted whole.

No. 8 was similar to the preeeding up till the ninth day, and both showed a slight discolouration on the third day after infeetion. At the end, infection extended all over, and tufts of sporangia were produced very generally over the entire surface.

It has now been conelusively shown that tomatoes and potatoes are mutually infeetive, and that, even with the tough skin unbroken, spores falling upon them when moist ean produce infection, and a fresh erop of spores may appear within nine days.

A diseased tomato, like a diseased potato, may naturally produce spores on the unbroken surface while still attaehed to the parent plant, the fungus filaments protruding through the skin in both eases. But the tomato differs in producing spores internally as well, for the filaments of the fungus ramifying in the pulp, baar spores freely in the eavities of the fruit containing the seeds.

It is evidently bad policy to plant tomatoes and potatoes side by side, as is often done in our eoastal distriets, for there is always a risk of one infecting the other, and consequently both crops may suffer. Further, the tomatoes growing in the winter have boen known to be affected with blight, and thus the spores may $b_{3}$ earried to the young potato erop, and from the potato to the tomato for one-half of the year at least; until the dry heat of summer arrives to hold them in check.

A very simple way in which artificial infection may be brought about is to place sporangia in a small phial of water. After shaking it well up, a drop is plaeed on the skin of the potato or tomato, and a cut or stab made through the drop into the skin. Twenty healthy potatoes were infeeted at the same time in this way, and all bscame diseased., every one showing signs of it in about seven days. When the skin is unbroken there is not the same certainty of infection. 
Other Plants Affected.

It is always useful to know the plants liable to bs aftected by a particular disease, bacause if they are weeds, then they can ba destroyed or kept down, and if of economic importance, and cultivated, they require to be protected against it.

It is not at all uncommon on tomatoes, in which it produces a fruit rot, and, so far, in Australia, it has only bsen found on this fruit in Victoria, New couth Wales, and Queensland. It also occurs on various species of Solanum basides the potato (Solanum tuberosum), and has bsen met with in Victoria on the Kangaroo Apple (Solanum ariculare), as shown in Fig. 119. At Karde lla, it was found towards the end of February, 1911, on this plant, which was growing freely among the potatoes, at different stages of growth, som ${ }^{4}$ in flower and others in fruit. It occurred on almost every plant, sometimes only on the leaves, where it produces large pale brown patches, with a copious development of spores at the margins, on both upper and under surfaces. It also attacked the stem, and was very common on the young shoots, eausing them to turn dark brown, and on the stems it forms demse patches of the mould. Early in March, Mr. Symour also found it at Fish Creek, where the disease was very bad on the potatoes, as it was also at Kardella.

Although there was plenty of the Black Nightshade (Solanum nigrum) growing in the same fields, the fungus was not found on it. I lave met with it frequently in potato crops, with the badly-diseased leaves mixed up with it, and yet it escaped, so that it is piobably immune. It is liabl: to bs attacked, however, by the Early Blight.

It is interesting to observe the plants artacked by the Potato Moth (Lita solanella) for comparison with those known to $b$, infected by Irish Blight in Australia. I am indebted to Mr. C. French, jun., for the list, which is as follows:-Australian Tobacco (Nicotiane suteolens), Black Nightshad. (Solanum nigrum), Cape Gooseb rry (Physalis perweiana), Devil's Apple (Solanum sodomaenm), Potato (Solanum tuberosum), Tobaceo (Nicotianu tabacum), Tomato (Solanum lycopersicum), Tree Tobacco (Nicotiana glauca), Trumpet Weed (Datura stramonium).

It is not recorded on the Kangaroo Apple, which is subject to Irish Blight, but it is found on the Black Nightshade, which appears to be immune to the potato disease.

The average grower regards cverything which causes the leaves to turn brown, or the plant to wilt, as a ease of "blight," and it is supposed to b. of the same nature as potato blight. A great variety of cultivated plants have been sent to me as being affected with the same kind of blight as the potato, and even the common bracken fern, turning bown, has been brought forward as an instance of the prevalence of this disease. But it is a wise provision of nature, as we might say, that these disease-causing fungi are often limited in their scope, and can only infect and gain an entrance into certain plants. While this disease is not confined to the cultivated potato, it is practically not found outside of the potato family, and there is an evident necessity for clcan cultivation in general, and the destruction of solanaceous weeds in particular.

\section{Diseases Associated with Irish Blight.}

The occurrence of various diseases along with the blight has already been incidentally mentioned, but it is desirable to point out definitely what diseases are associated together, as some of them are often confounded with it. Thus the Early Blight has baen frequently associated with it during the past season, and the curling up and withering of the leaves were often 
attributed to that cause. The Irish Blight may attack the potato-plant just as early as the other, but, generally speaking, the Early Blight affected the plants bofore flowering, while the Irish Blight appearce to be most virulent at or after flowting. Fnsarium was very frequently associated with it. as well as Wet Rot, and Rhizoctonia. and rhe Black I)ot disease appeared along with it under cireumstances which suggested rhat both diseases harl bsen importcd in the seed recently brought out from England. It was even found associated with Eel-worm, but only rarely. Th: appearance of these different discasos together show that they are subject to similar climatic conditious.

The diseases so far found associated wirle Trish Blight in Australia are Early Blight, Dry Rot, Wet Rot, Rhizoctonia, Black Dot, and Eel-worm disease, or "Blister."

\section{Sumary of Ponts of Practical Timortaxce.}

The potato blight is a splendid eximple of a plant disease caused by a definite fungus, and the purely scientific study of its life-history in the liboratory is the basis on which the practical treatment of the disease is founded. Numerous experiments have ben carried out with the different stages from spawn to spawn, bat only such points will bo briefly given as are of practical importance in dealing with the cradication or prevention of the disease.

1. The mycelium of the fungus lives in the tubs, and, under suitable condirions, may develop and propagate the disease.

Hence only clatu seed porators should be planted, obtained, if possible, from districts where the disease is not known to exist.

2. A diseased potato may communicate the disease to a clean potato by contact, either from the mycelium or from the sporangia growing on the slirface.

Hence seed potatoes should be carried in new bags, to prevent any possibility of infecrion.

3. Potatoes and tomatoes are mutually infective, and the latter, from their succulent nature, propagate the disease very rapidly.

Hence tomatoes should not be grown where diseased potat oes have been. or the reverse.

4. The fungus may pass through all the stages of its life, from sporangium to sporanginm again in six and three-quarter days.

Hence the apparently sudden appearance and rapid spread of the disease.

5. The mycelium may produce a crop of sporangia, when young and vigorous, in fifteen hours, and, in the case of tomatoes, in about seven hours.

Hence, to prevent the spread of this fungus from plant to plant, by means of sporangia on the leaves, spraying with Bordeaux mixture or copper-soda solution may be adopted to prevent their formation.

6. Sporangia have their development arrested by the action of formalin.

Hence dipping whole seed-potatoes in formalin will destroy any sporangia on the surface of the tuber.

7. The formation of sporangia is prevented by a dry heat of 80 degrees Fahre, while a moist heat of the same temperature eneourages their formation.

Hence the disease is not likely to spread in distriets where there is a continuous dry heat of this temperature, about the time when the fungus would produce its fructification. 
8. Sporangia lose their vitality if liept dry for twenty hours.

Hence their life is limited, and, even if transported by the wind to a distance, they must reach their proper host-plant, or perish.

9. Zoospores are incapable of germination after baing kept dry for twenty-four hours, but they germinate readily in moisture.

Hence mists and dews are sometimes said to cause the disease, because ncecssary to the production and germination of zoospores.

10. The mycelium inside the tubar is sterilized when subjected to a dry heat of 120 to 130 degrees Fahr. for four hours, without interfering with the growing power of the potato.

Hence seed potatoes could bə treated in this way, and secure a district against infection, when planted in ground free from diseased potatoes, and at a suitable distance from other potato-growing districts, where heating is not resorted to.

11. Special seed-potatoes could ba imported for trial, even from countries subject to the disease, by submitting the tubers to dry heat, and thus preventing any risk of introducing the disease.

\section{Factors Ixflementate the Disease.}

\section{Heat axd MoIstere.}

The controlling influence of the weather has already baen doalt with, b it the special factors of heat and moisture may bs further considered. It would appear that wherever the potato can bs grown, there the climatic conditions favorable for the development of the fungus will also be found. Thesc conditions may not ba present every season, and it is conceivable that potatoes might naturally ba exposed to a dry heat of 120 degrees Fahr., sufficiently long to destroy the efficacy of the dormant mycelium inside. But fresh potatoes are constantly bing introduced, and these would probably carry the disease in some of the tubrs.

Because the spores of the fungus could not bs produced in a dry heat of 80 degrees Fahr., it was firmly balieved by manv that the disease could not gain a footing in many parts of Australia. Helms, in his Report in 1895, (referred to under Literature) writes as follows:- "Therefore, as the summer heat as a rule exceeds this tcmperature in most parts of Australia, and undoubtedly in New South Wales, there is little fear that this destructive fungus will establish itself here, if it should ba introduced. It is, however, b-ter to guard against its introduction than to depend too much upon the climintic safeguard, bscause even with the greatcst of care, investigators are sometimes. led into error."

The past season has shown how the disease may flourish in the States of the Commonwealth, even including tropical Queensland, where the steamv heat rather favours it. The soil temperatures, too, may bs sufficiently high to prevent the dormant mycelium developing, and in West Australia 15, degrees Fahr. has bsen recorded in potato-growing country. While, therefore, a dry heat is inimical to the disease, and might stamp it out altogether, thr. heat and moisture combined, necessary to the growth of the potato, will alrays insure its reappearance if the potatoes nsed for "seed " contain the mycclium, or spawn, of the fungus.

\section{Temperatere.}

There are certain limits of temperature between which this fingus thrives, and it is very important to know these, bacause certain districts may b. more favorab'e to its development than others, and the virulence of the 
disease may depend on the season at which the potatoes are planted, and the time when they are approaching maturity. Thus Erikison found that no sporangia were produced when the temperature rose to 77 degrees Fahr. on the one hand, nor when it fell to $t 1$ degrees Fahr. on the other. The optimum temperature, or that most favourable for their drvelopment, was found to b. 7.2 degrees Fahr., while at 3.5 degrees Fahr. neither mycelium nor sporangia were produced.

It is important to rememb'r that the temperatures given refer to dry heat. I found that sporangia were not formed at 80 degrees Fahr, dry heat, ven when kept at that heat for five dars in an incubator, but at 89 degrees Fahr, in a moist heat. they were produced luxuriantly.

The myeelium is also completely strilized when exposed for four hours to a dry heat of 120 degrees Fahr., and when a small portion of this mycelium was inserted into a healthy potato kept moist, no effect was produced, sinowing that the vitality of the fungus wat completely destroyed.

\section{SOHL TEVPERATTRES.}

II", Catton Grashy. F.I., has given a numbre of readings of soil tempratures for Perth, West Australia, as follows and they show that there may b. sufficient heat in the soil to destroy the mvecelium in the tuber :- "Among others are the following ( ) February 1, with a shade to mperature of 107.t (ligrees Fahr, a thermometer placed laalf an inch under the surfaee of dark sandy loam near the plot in which potatox-s had b.en grown, registered 148 degrees Fahr. On February 13, when the solar reading wat 143 degrees, and the shade tomperature was 91 degrees, a thermometer supplied to me by the Meteorological Department, registered 1.50 dregrees half an inch bolow the surface of dark dry loam, and log degrees at five incles bs low the surface. I also quoted the following figures given by Mr. Pfizer, Science Haster of the Perth Hodem School:- Shade temperature, 110 degrees ; soil temperat'ue at one inch, 1.51 denrces; two inehes. 147 degrees; bstween four to five inehes, 133 drurees,"

It must bs remembred that the soil when covered with a growing erop would ba more shaded than when bare, nevertheless, a temperature of 120 to 133 degrees, four to five inches b low the surfaee, would exercise a destructive effeet on any mycelium in the tubers. The ferment, or diastase, which dissolves the starch in the potato, is also then at its maximum activity, and altogether the eonditions are favourable for the growth of at least a healthy potato free from blight.

\section{Soll.}

The disease has occurred here in rvery variety of soil and situation, on the hills as well as in the hollows: but the determining factor is whether the moisture is retained or not. In the gray soils, whieh dry slowly, keep the moisture well, and allow the water to lodge, the blight is usually worst and appears earliest: while the red soil in the same pardock, whieh is loose and allows the watar to flow freely through it, mav bs eomparatively free.

But when the spores are formed on the leaves, and are washed down bv the rain into the soil, it is found that a greater downpour is required to eause the tubars in the stiff soils to decay than in the loose sandy soils, probably owing to the spores less easily filtering through.

\section{Celativatiox.}

There is a good deal of virgin land being brought under cultivation and planted with potatoes, and I have seen instances in the same paddoek where a portion of the land previously cultivated was only moderately attacked, while the portion nerer cultivated was absolutely the worst. 
It is generally reckoned good practice not to have the rows too close together, so that there may ba plenty of room left for "earthing up, "or "moulding," Jensen submitted this to the test of experiment, and found that the tubsrs covered with a good layer of earth did not suffer much, even although the foliage was badly affected. The spores camot readily reach the tubars when carried down to the soil by rain or otherwise, hence the lessened infection, but there are drawbacks to the practice in certain soils. In loamy soils the heaped-up earth bəcomes cracked by the sun's heat, so that the tubsrs are partly exposed, and if the spores are washed dom by the rain they infect them directly. Besides, the sloping sides of the rows readily bscome dried up by the heat, and this has an injurious effect on the young tubers, and prevents them obtaining their full size. On the other hand, if tubers are not earthed up, they are apt to appear above the ground and $b$, badly attacked by grub.

\section{Maxurixg.}

The whole question of manuring in relation to the disease has ret to be studied under our conditions, but there is always the danger of too much boing claimed from the treatment of the soil by scientific manuring. It is held by some that all that is necessary to banish the disease is to treat the soil in such a way that the spores present in the soil, and ready to attack the plant when conditions are favourable, should bs destroyed. But there is no evidence to show that the disease originates from spores in the soil, and in fact is contradicted by the numerous cases where tubsrs were blighted in land newly broken up.

Again, it is confidently asserted that the healthy plant, like the health animal, defies disease, and that it is only when the general health is lowered that danger arises. It is considered that the resistant quality which confers immunity is the direct result of a properly-nourished systcm. But while the condition of the plant itself is undoubtedly of great importance, the nature of the parasite has also to be taken into account. With the most scientifie manuring the disease is still liable to appear, and while a well-balanced ration in the matter of plant food is desirable, and a proper supply of potash and lime must be maintained to produce a crop, still it is going too far to say that instruction in the elementary principles of scientific manuring is the remedy for this disease.

The diseased tub rs possess, according to Lawes and Gilbart, in their dry substance, a higher percentage of nitrogenous matter than the sound tubars, especially the central portion of the diseased tubsis. The sap from the brown tissue traversed by the fungus was also much poorer in nitrogenous substances than that from the tissues not invaded by the fungus. so that it would appear that the fungus requircs large quantitis of nitrogenous substance for its proper growth. In keeping with this, it has bren found as the result of numerous experiments in different parts of the world, that the use of highly nitrogenous manures favours the discase. while. on the other hand, potash and phosphatic manures tend to make the rubermore resistant. The use of fresh stable manure is generally considered to favour the disease. In the course of experiments on the manuring of potatoes. Professor Wright made observations on the effect of manurial treatment on the disease. He found that potatoes planted on farmvard manure alone in the drills braird earlier than those planted on artificial manure, either with or without farmyard manure, but at the same time they we re liable to suffer from an earlier attack of the disease. On the other hand, potatoes planted on suitable artificial manures alone applied in the drills, brairded more stowly 
than those planted on farmyard manure, with or without artifieial manure added, but they were not liable to suffer so early from the attack of th? disease.

\section{THe of DigGixg.}

The question is often whed, "When should blighted potatoes bo dug in order to minimize the loss as much as possible?" and various answers have bsen given to it.

At the Iaine Agricultural Expariment Station (1905) experiments were carried out to test the effect of the time of digging upon the subsequent development of blight, and it was shown that the late dug potatoes were far less liable to blight in the cellar on storing than the early dug about a month bsfore. On the other hish, the evidenee at the Vermont Agrieultural Experiment Station (1892) pointed the other way. "We are eonvineed from our observations that the sooner the potatoes are dug after the tops are blighted, the less loss there will ba from rot. The eommon saying that it is batter to let the potatoes rot as much as the r are going to in the ground, since they will ror to the sime extent if dus and placed in the eellar, is wrong and misleading."

The conditions prevailing at the time of ripening have such an influence upon the development of blight. as well ins the eonditions under whieh the tribers are storcd, that the relation of the date of digging potatoes to the development of blight in storage would require to $b$ settled by experiments conducted here.

After the stalks have died down and growth has eeased, it is generally found that nothing is gained by leaving the potatoes much longer in the ground. As an illustration of this, one portion of the diseased plot at Kardella was dug on 3rd April, and another portion on 16th May, to test the relative amount of diseased tubars on the respective dates.

At the first digging the percentage of diseased. tubers was 81 , and at the seeond digging, or six weeks afterwards, it was 49 . In the interval the badlydiseased tubars had rotted away, and of course the proportion of healthy tubars had vastly increased. There is alwavs a risk of the discase extending to healthy potatoes, and it is advisibble to liave the potatoes dug and sorted. out as soon as possible.

\section{DRAIXAGE.}

There is no doubt of the value of chainage in cheeking the spread of the disease, sinee lumid conditions are necessary for the luxuriant development of the fungus. Low-lying and domp spots are perfeet breeding grounds, abl it often spreads from there as a centre, so that whatever encourages the proper cireulation of moisture in the soil and prevents the aeeumulation of stagnant water, will tend to reduce it.

\section{Destrection of Refuse.}

Diseased stalks and rotten tubars should bs colleeted and destroyed, either by borning or builing in the case of tubsts. It is known that healthy tubsrs may contraet the discase from b.ing mixed up wirh the refuse, and probably the mycelium remains dormant in the stalks, just as it does in the potatoes. Blighted hanlms should never he placed as a eovering to the potatoes loagged in the field, as the spores are liable to infect the healthy potatoes. 


\section{Disease-Resistixg Varieties.}

It is stated, and has ben proved in a general way, that the thick-skinned red varieties, rich in starch, are less liable to the disease than the thin-skinned white rarieties, poorer in stareh or less " mealy." It has also b en observed that there is a relation between colour and vitality, or robastness, not only in the tubers, but in the foliage as well. A pale green colour indicates a woaker constitution than a dark green, and such a plant is less resistant than the other.

In countries where the disease has existed for a considerable period, it has bren found that some of the varieties are much less liable than others, and it should always bs the aim of the grower in raising, testing, or introducing new varieties, to secure, if possible, a disease-proof strain. It is only by local experience and experiment that this can be determined, for under different conditions the same varieties may bshave differently.

In Victoria, there was considerable variation among the varieties grown as to liability to blight, but it must be remembered that a single season or two is no criterion. Even in one part of the State a variety snch as Snowflake was found to be badly affected, while in another it escaped, so much depending on the time of planting, the age of the seed, the soil, and the season. Among the varieties generally found to be badly affected, the following may bo mentioned:- New Zealand Pink-eye, Carman, Snowlake, and Brownell's Bcauty, and of these Carman and New Zealand Pink-eye were certainly the most susceptible. There was also a variety known as The Bruce, raised by Mr. Findlay, and introduced in 1886, which was apparently free when dug; bat affer being kept in the bag for about a month, the disease bicame virulent in the form of sunken patehes and browning of the tissue beneath. The raising and testing of new varieties in a scientific and systematic way should be encouraged, as disease-resisting varieties may the riby be securcd, retaining this quality at least for a period of years.

Through the courtesy of $\mathbf{F}$. de Castella, 1 am enabled to give a list of blight-resistant varieties of potatoes, as recorded by Professor Aumiot in Progris Agricole, for 5th February, 1911. His successive experiments especially those of 1910 , whicl was a very wet year, have fully proved the ralie of spraying in warding oft the attacks of Phytophthore. He adds that agriculturists should not hesitate to rencw their seed by the adoption of recommendable new rarieties.

Table 1 . - New Tarieties Recommexden.

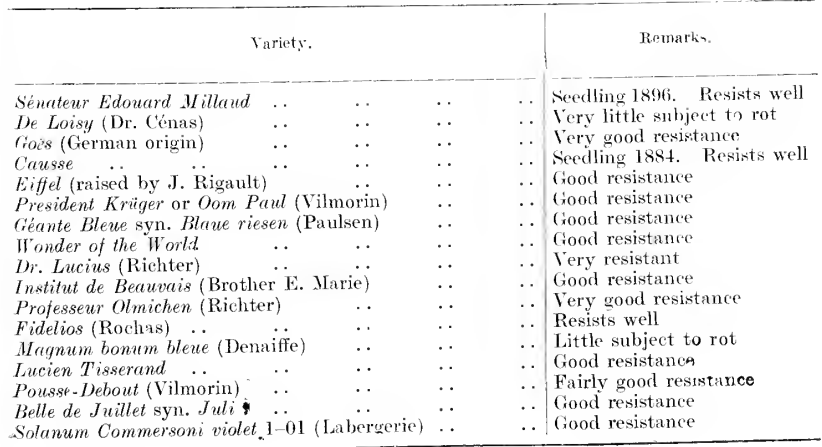




\section{SEeD Potatoes.}

of all the factors influencing the disease, that of the selection of the seed potatoes is the most important, and ought to b? given the first place; but it has already boen so much insisted on, that it is only mentioned here in commexion with the age of the seed and the use of sprouted seed.

\section{Alge of Seed-Early and Late Diug.}

This question of the time of ligging of potatoes has already been considered in connexion with tha development of discase in store, and it is in relation to the development of dise ase in the crop that tle subject is dealt with now, not even taking into arcount the matter of vickl. The age of the secd planted, i.e, the length of time between digging and plinting the produce, is supposed to have an effect upon the disease-resisting power, but carefully conducted experiments are necessaly to pore the point. It is not a question of mature and immature seed of serel that has bern lifted be fore it has had time to :ipese, and of tubers left in the ground till ripe-but of length of time that ther are out of the eromel. Thus potatoss wore planted by a grower in August, I909, and dug in Marell, 1910. They wo then thoroughly ripe and hard in the skin, and were pittad in nice clean straw. They were kept in pit for fully three montls, and planted in the beginning of July, and when dug in Novembsr they wre found to be batly diseased. Potatoes said to be of the same varicty were also planted in the beginning of November, 1909, and dog in June, 1910. The were pitted similaty to the previous lot, and some of this late dug soed was planted alongside the early dug seed at the same time. The result was that the late dug seed, about three months younger than the rearly dug seed when planted, was much less blighted (about 5 per (ent.) than the latter or early dug seed (about 20 per. cent.) There was satel to be no differenee of soil or season to aecount for this, and as it is said to have oceured in several pardecks, it was concluded that the age of the seed had something to do with the result. The early dug seed was observed to come np a little quicker than the late dug secd, bat the plants we re readily affected by sharp winds or lrosts, and it was nocireable that while the product of the carly dug seel completely suceumbed in some instances, that of the late dug serd survived and threw out fresin shoots.

Some of the growers are so convinced of tle dangers attendant upon the planting of early dug secel in this particular district where the soil is a rich volcanic, of its greater liability to suffer severely from frost and blight, that they have given up the use of it altogether. They consider that this older seed has at diminished vitality compared with the younger seet. It is plaved out, as tley say, and deficient in vigon, so that it lacks resisting power. I am not aware of any definite experim nees carricd ont with carly and late dug seed, but the smbject is well worthy of attention.

\section{Sprouted and Insprouted Seed Potatoes.}

The system of sprouting seed potatoes has bec n for a considerable time in use for the purpose of securing early crops, and thercby procuring the highest prices; but it is now found to ba so profitable in itself, that the practice is being extended to nain-cop varieties. The sprouting of the seed is also known as "greening," or "boxing," or "traying," and consists in phiche the tubers, after they are lifted and have become dry, in shallow boxes is that unetr.e the an airy, well-lighted, and well-ventilated shed. The result becomes active influence of fight and air, the dormant surface of the tub $x$ or growth, and sprouting occurs. 
The advantages of thrs boxing the tubars intended for "sets" are :-

1. The production of one or two stout dark-green shoots at the top end of the tuber, instead of a numbsr of weak sprouts.

2. There is no further necessity for handling, as the tub rs are placed straight away in boxes.

3. The yield is considerably increased, the average increase baing over two tons per acre.

t. The crop matures earlier, and, consequently, can bo dng earlier; or it can ba planted later, if the state of the weather requires it.

5. Not only is a heavier and an carlier crop prodnced, but only healthy "sets" need bo planted, since any signs of disease are likely to bo detected.

6. The tubars can be planted direct from the box.

There are two features of this method which are likely to ba of service in dealing with the potato blight. The one is the rapidity of growth, so that the tr:bars are a shorter time in the ground, and, as a consequence, are likely to $b$; well advanced b fore the danger from blight arises. The other is, the planting may bs delaved for several weeks, if necessary, owing to an unsuitable planting season, without diminishing the yield.

The further advanced the crop is, the less damage the blight is likely to do, and this well-known fact is strikingly illustrated by Professor Wright, in, his Report on Experiments on the Seeding of Potatoes :- "It would appear, therefore, that soft immature tubars succumb much more readily to the attack of the disease fungus than fully formed and more mature tubars, and it follows that at the period of the summer, when an outbreak of disease occurs. those crops of potatoes that have advanced furthest towards maturity should suffer less from the attack than those that are in a less advanced stage of growth. The promotion of the rapid growth of the crop during the early part of the summer is, therefore, one of the means indicated for mitigating the destructive effects of the potato disease."

It is because the sprouted seer may become an important means of lessening the loss due to blight that $I$ advocate it so strongly, and those farmers who are so anxious to be supplied with a disease-resisting variety, have here a method ready to their hand, whereby they can increase their profits, and at the same time minimize the risk from disease. The method is so simple that any one can carry it out, and the following description, from Wright's Standard Cyclopedia of Modern Agriculture (1910), will give the necessary information:- "To expedite the crop the seed sets shonld be sprouted before planting. For this purpose, boxes or trays are used. The most convenient pattern is the Jersey box, $24 \mathrm{im}$. long, 12 wide, and 3 deep. The comer pieces are $7 \mathrm{in}$. in height, and strong, so that the boxes can rest on the top of each other when piled for winter storage. There is a cross handle for carrying, which is tenoned into the side pieces, and the whole forms a light, handy, and durable utensil which, with ordinary care, will last for years. The price is about 30s. per 100 completed. Each box holds about $201 \mathrm{bs}$. The seed potatoes are filled into the boxes until they are level with the sides. No particular care is taken to have eyes set upwards; the potatoes are simply poured indiseriminately into the boxes, and left to bud as nature suggests. If large sets are used, they will bs one deep in the boxes, but if a smaller size they may ba two or three deep. That does not matter, as the sprouts find their way up through the interstices. When the boxes are filled they are piled up one on the other to any height which may be found convenient. The 
boxes should b. filled in oarly autumn, b. fore the tubs has commenced to sprout, so as to prescrve the first intention. Immature tubers make the best seed for spronting, and yield an earlicer crop than ripened tubers."

"light is nefestary in a sprouting house to make the sprouts tough and hardy, and no heat need be applied, except to proteet from frost."

In sprouting seed it will generally be observed that if any of the tubers are diseased, rhey sprout much earlior than healthy seed. While examining a fiek of potatoes badly affected with Irish Blight, at the time of digging (arly in , June (winter), I observed that not only had a number of diseased tubers lying on the ground begun to sprout, but that potatoes still in the ground, and attached to their parent ste-m, had produced leafy shoots above the ground, in some cases reaching a height of six inches. There was also occasional sprouting in the healthy tubsts, even while still attached, but it it was quite a common eccurrence anong those that were diseased. It is known that a potato attacked by the fungus respires more actively than the healthy tuber, and this may have something to do with forcing the growth and causing quicker ermination.

It woulf be at least worthy of trial to set aside a portion of ground for seed purposes, and use sprouted seed. Careful selection of seed is one of the foremost metheds of prevention, and lads aliso an important baring on the success of spraying.

In the Agricultural fommal of Tictoria for March, 1911, Mr. Seymour, the potato expert, has an article on this subject, in which drawings are given of the trays and sheds used, instructions as to the best time for "boxing "or "traying," and the best varietics to use, and it is pointed out that sprouted seed may be planted eight weeks later than unsprouted.

\section{Storage of Seed Potatoes.}

On account of the provalence of lrish Blight, increased attention is being given to the storage of seed potatoes, and while "traying" or "boxing" of the seed is recommended, there are simpler means of attaining the same end in oux genial elimate. The object to be aimed at is to lieep the seed dry and secure against frosts, while allowing a free eireulation of air and plenty of light. It is not an uncemmon praetice to lay out the secd under the shelter of pine trees, but this does not protect them altogether against rain, although some growers have provided a rough covering of galvanized iron for the purpose.

In some districts there is plenty of rough timber, and a storing shed may be simply and cheaply ereeted. Rough rounded timber may form the two sides of the shed, leaving the ends open, with a thatched roof overhear. Winc-netting can bo arranged in lavers inside, on which the seed potatoos are spread out. A calico tent could also be uscd for a covering, erected in a sheltered spot, and shelves of wire-netting formed inside for laying out as many potatoes as possible, cxposed to light and air. The potato lives and grows, feeds and multiplies, deears and dies, and when it is to be used for "seed," should have plenty of light and air. Even in "pitting "potatoes for domestie use, they should be kept dry and provided with air. This may be simply seeured by constructing what the farmer is familiar with as a chaff pit. Upright posts are driven into the ground on each side of the space to be used for a " pit," and palings nailed across so as to allow the air to enter freely. A flooring of dry straw may be provided, and the potatoes piled on this to the required height, with a good covering on top to keep ont
the rain.

Potatoes are sometimes stored in bags, but this cannot ba recommended when they are gathered from a diseased crop. 
A bag of badly blighted and rejected potatoes was reeeived on $15 \mathrm{th}$ May, 1910. One half was spread out on the floor of the storeroom, exposed to the light, while the other half was kept in the bag alongside. At the end of 15 days (30th May) they were examined. Those on the floor remained dry and firm, drier even than when laid down, and practically without smell. while those in the bag bacame absolutely rotten and slushy, emitting a vile stench.

There is no doubt that potatoes will keep batter and longer when exposed to light andair, than when placed in bags stacked one above the other, as they often are.

\section{How the Potato Blight is Spread.}

In order to cheek the spread of any disease, whether of plant or animal, it is necessary to know how the disease originates, and then to follow it course, so as to step in and either prevent it entirely, or at least to reduee its destruetive effeets to a minimum. In the ease of potato blight, we know that it is caused by a fungus, for we ean take healthy plants, as well as healthy tubers, and produce the disease in them by means of this fungus. The weather is a contributing factor, for just as we sometimes sow wheat grains and the absence of moisture prevents their germination, so the fungus will not develop if suitable weather conditions do not accompany it.

From what we already know of the life-history of this fungus, as to its nature, the particular symptoms it produces, and the conditions whieh favour. or hinder it, the various ways in which it is propagated may be more or less fully determined. The starting point is in the tubar itself, for this is the only possible way in whieh the disease can have reached Australia. As already shown, the mycelium retains its vitality, even in the dried up and mummified diseased tuber, so that the living and the dead may both carry the infeetion.

The myeelium in the tubers, and the spores are the two principal means whereby the disease is spread, and while recognising both, there is a danger of the one being unduly extolled at the expense of the other. There is no doubt of discased tubers spreading the blight, but it is equally true that the spores may be swiftly carried from plant to plant, and cause an apparently sudden decay of the tops. A striking illustration of this was shown at Kardella, where hundreds of kangaroo apple plants, which had sprung up in freshly-ploughed land, were badly infected from diseased potatoes growing in the same field.

How the healthy tuber brcomes diseased is the main question to be answered, and it is a question of such praetical importance, and about which there is so much difference of opinion, that even at the risk of repetition, I will briefly enumerate the possible sources of infection. The answer to this question is also usually so delightfully rague, that it is neeessary to be more explicit about it, and an illustration may be given from one of the latest pronouncements-" The disease reaches the tubers either by fungus filaments passing down the stem, or by spores shaken on the soil and washed down to the tubors by rain."

1. The mycelium in the seed potatoes may pass into the new shoots and infect them. The best proof of this is that the diseased potatoes have been planted, and the fungus has developed in the green and suceulent stems and leaves, under conditions where infection from outside was impossible. That the myeelium in the tuber grows in, and with, the young plant can be easily and exaetly observed.

2. The fructifieation of the fungus may derelop on stem and leaf, as well as on the "apples" or "plums," and the spores may ba carried by the wind or other agencies to neighbouring potato-plants and infect them. Spores 
have been taken, either direct from the potato, or after being placed in water and laid upon the leaves of healthy growing potato-plants. The inoculated leaves soon became infected, and ultimately the entire plant above ground suecumbed. The spores are easily detaehed, readily earried by the wind, and from their stieky mature, adhere to whatever they come in contact with. If this is a potato-plant, and there is sufficient moisture, the spores will germinate; but if not a member of this family, then they simply perish. Before it was so clearly recognised as it is now that the disease is spread through the mycelium inside the tuber, that the sporangia succumb so easily when dry, and that the swimming spores are so short-lived, there was a good teal of exaggeration indulged in about air-borne infection. Worthington $G$. Smith practically places no limit on the extent of its spread by means of windborne spores, for he writes:- "Now if we could imagine the whole of Britain free from the disease, and a single infected field somewhere in France or Germany, a single puff of wind would send the spores over to us, and we should at onee be as badly off as if we had suffered from the disease from the first."

Dr. Buller, in his "Researehes on Fungi," has pointed out that the spores of all the higher fungi, sueh as mushrooms, toadstools, and braeket fungi, are very adhesive, just as in the potato blight fungus, and he observed that when examined in the open the spores were seen to drift away sideways, and not to be caught up by vertieal currents. Now in the case of the potato blight fungus thert are some who imagine that the spores are carried upwards, and that they hover over potato fields, ready to be carried down by rain or dropped down in thunderstorms. But there is no warrant for this assumption in the general behaviour of spores, and it is highly probable that in the potato blight the spores may be blown to adjoining fields, but are not caught up in the air and transported for immense distanees.

3. 'The spores may also fall from the leaf to the soil and be washed down by the rain, so as to infect the new potatoes. Some of the potatoes, at least, are reached in this way, and the young tubers can be directly infected, as proved by experiment. The earthing-up, or " moulding," process of Jensen is based on the view that if there is a sufficient laver of earth covering the potatoes, the spores from above will not reach them. The usual course of the disease is that the foliage is first affected, and the leaves are generally almost all lilled by the blight before many of the tubers are found to be diseased. At Kardella, where badly blighted potatoes were planted, the fungus was found on every plant about flowering time, sometimes on stems as well as leaf, and not a single tuber was visibly affected. It does not neeessarily follow that because the tubers are affected generally after the leaves, it is threfore through the leaves and the stem that the mycelium reaehes then. The fungus usually develops first above ground, where the food materials are being manufactured, then it passes along to the tubers where food is being stored, when there is aerial infection.

4. The mycelinm may pass down the stem from the leaves, and then along the underground branches, so as to infect the tubers formed upon them.

When potato tops were infected, as already described, the mycelium passed down the stem even to the very tip, and although not a single tubar in this particular case was affected, they were probably moved too soon for the mycelium to roch them.

5 . 'The natural way for the myeelium to pass from the seed potato is along the stem of the young shoot to the leaves. Then as the plant grows, the mycelinm in the underground portion of the stem can readily pass along the tub r-baring branches, as is evident from Fig. 109. In this way the 
tubərs are directly infected from the ascending mreelium, and explains how the tubars mav either bs infected from the stem end when the mvceliun pirsses along the underground branches, or at any part of the tubir when infeetion arises from the falling spores. In the case of infection by windborne spores, it is the descending mveelinm which reaches the tubsrs. It is rather difficult to prove the direet passage of the mycelium to the tubrr. I have tried growing potatoes by means of "water culture," but the diseased potato invariably rots. However, one is now growing in straw, kept moist, as well as a numbrr planted in my garden, and it may by possiblo to trac. the earliest development of blight in the young tubrs.

6. The fungus may spread from tubar to tubsr in the soil. It was the wholesale rotting of the tubers, as in Fig, 110, and not only the few sufficiently near the surface to $\mathrm{b}_{3}$ reached $\mathrm{b}$ r the falling spores that led to the theory of the descending myeelinm infecting them. But the tubrrs may bo infected by the mycelium arising direetly from the seed, and also by spores produced by the diseascd tubsrs underground.

At digging time, the fungus is often found growing in tufts from the surface of diseased and decaying tubers, always accompantied by a profuse development of spores. The soil conditions too, when the land is wet and heary, are evidently favorable for the infection of the tubsrs, as some of the spores were found to ba producing swarm-spores, thus showing that they were in a full state of activity. These spores coming into contaet with young, moist tubors could undoubtedly infect them, and thus the disease mav b spread from tubs to tuber in the soil. Spores falling from the foliage might start the infeetion in some of the young tubars, and then it could spread to other tubsrs in the soil.

7. Even although licalthy "sets" are planted, the potatoes left in the soil from the preceding crop may grow and spread the disease by means of spores produced in the ground. This is simply a case of the disease spreading from tuber to tubar in the ground, ever when the seed planted is clean.

I have frequently dug diseased potatoes, particularly where the soil was moist, and found the sporangia freely formed on the skin, and eapable of infecting adjoining healthy tubars.

8. The rotting haulms and tubars allowed to lie on the ground may also canse infeetion. The potato shown in the coloured photograph (Fig. 1) was picked up on the field in a damp distriet, and little tufts baring spores were scattered all over it.

Professor Marshall Ward has used strong language in referring to the carelessness exhibited by growers, for he writes:- ") (If course only a madman would allow the diseased haulms of the potatoes to lie about the ground, or to ba plaeed on the store heaps, or in any way to endinger the crop, if he understood the foregoing facts. It is bacause agricalturists do not sufliciently appreciate the power of this invisible little enemy that so much apparent recklessmess is shown in this respeet."

9. "Wild" potatoes hare ben known to ba affected with blight when the main erop las naturally died down and was clean, so that such potatoes siould ba removed, since the stalks remain longer green and are tasily recognised.

10. If hoalthy tub.re are brought into contact with. diseased tops while - ill producing the ir spores. they may contract the disease. Sound potatoes k. pt in a bag with diseased haulms bacame diseased. while similar potatoes ke.pt by themst-lves nuder similar conditions remained sound. 
11. If the refuse from the potato fields is added to the manure heap and applied to the following erop, there is a danger of infection. The mycelium is not destroved under these eonditions, unless the fermentation of the manure prodvees a heat of 120 degrees Fahr., so that the only safe plan is to burn the rubbish.

12. If diseased tubers are placed in store, especially if wet or unripe, heat is produced, whieh canses "sweating," and such a eondition is favorable for the production of spores.

These spores will reach adjoining bealthy potatoes and multiply, so that the untire mass may beome more or less infeeted. The spores are found on stored potatoes under conditions which show that the y have been developed there, and as to infeeting the surrounding sound tubers, there is no doubt upon that point, for tubers have been inoculated sueessfully on eut surfaees, as well as on the unbroken skin, espeeially when young. It is quite a eommon oceurrenee to have boxes of diseased potatoes sent from a distanee, and in transit there is a luxuriant development of the fructifieation on some of the tubers. The tubers should therefore be dry when plaeed in storage, and kept dry and cool for some time afterwards.

13. Tomato plants are sometimes grown between the potato rows, and ther might infect the potatoes, as it has already been shown that they are mutually infcetive. The fungus has been found on tomato plants in June and July, and the spores might be carried to the early potato erops, just at a stage when they are very suseeptible.

14. Native weeds, such as the kangaroo apple, may spread the disease, and such growths should not be allowed to flowrish in the vicinity of potato erops.

\section{Seeming Contradictions Reconcileo.}

I know of no plant disease which is so eontradictory in its various phases as potato bight.

I have planted diseased potatoes showing "eyes," but they rotted away and eame to nothing. Another similar lot grew and produced only healthy tubers, while the diseased potatoes planted on a large seale at Kardella produced a crop in which every plant was blighted. Percival, in his Agricultural Botany (1910), says :-_ '- 'Neveral workers at the subjeet, nevertheless, maintain that from disease-spotted tubers either healthy plants arise or none at all." That is, however, only a part of the truth, as I invariably find that when a number of blighted potatoes are planted, the resulting erop is, more or less, diseased. Massee, on the other hand, overstates the ease when he says :- "The produce of a diseased tuber is ahways diseased."

The most convineing proof can be given that a diseased tuber produces a diseased plant; although it does not neeessarily follow that this is always the case. I have dug up the old "set" still attaehed to the plant which was badly blighted on the tops, and the tubers were also slightly affected, a number of them, however, being marketable. The "set" was found to be diseased and the fruetification of the fungus was produeed from it in a moist ehamber. Further, the mycelium was found in the underground stem aseending from it, and there is no doubt that the plant was infected from the tuber.

Here it is elearly shown that the fungus aseends the stem, reaches the leaves and produees its fructification, but that the myeelium should pass down again to infeet the tubers seems to me a most unnecessary procedure, as the mycelium is already in every portion of the stem.

In those cases where the tubers are infeeted, without any disease being visible in the leaves on account of the prevailing conditions, there is no question of the disease being produeed in the tubers from the aseending 
mycelium; and where, as is often the case. infection occurs from wind-borne spores, the tubers are undoubtedly affected from the descending mycelium. But to say that the mycelium ascending to the leaf returns again to infect the tubers, shows a complete misunderstanding of the position, since the ascending mycelium already permeates the underground portion of the stem, ready to pass along the underground branches as soon as tubers are formed. Diseased tubers examined while still at tached clearly showed that the infection arose from the stalk and spread from the stalk end.

Then, again, there may be no visible blight appearing on the leaves while the tubers are diseased, and the tops nay be diseased while the tubers are sill healthy. With reference to the former, I visited all the potato-growing farms in a district previously blighted, and could find no evidence of blight above ground, but on digging some varieties, such as New Zealand Pink Eye, the disease was evident in the tubers. In fact, the spores are not developed on the leaves or stems in bright, dry weather, nor when there is a dry heat
of 80 degs. Fahr.

It is a common occurrence in the field up to a certain stage of growth, that the tops may be diseased while the tubers are healthy, and the experiment of infecting the tops proved the same point. It is generally considered that the disease is first visible in the leaves before it appears in the tubers. but this is certainly not always the case under our conditions.

The disease may start from the stalk end of the potato, or it may begin at any part of it. In the former case, the mycelium has passed along the underground branch or rhizome to the tuber (see Fig. 109); in the latter, the potats has been infected through falling spores or by means of a.r adjoining diseased tuber. But there is one appearance I have always found constant, and that is, that the browning of the tissue, due to the fungus, invariably starts from immediately beneath the skin.

There is another contradictory appearance which nay be mentioned and which has created a good deal of misunderstanding. The disease may take the form of a dry, brown rot immediately beneath the skin, leaving the potato quite firm and without any perceptible smell, or it may render the potato soft and slushy, giving forth an offensive odour. In the former case, the disease is known as Brown Rust, and it has been stoutly maintained that it is not the blight; but the eonvincing evidence of its identity with that disease is the fact that it always gives rise, when kept moist, to the fructification of the potato-blight fungus. In the latter case, the bacteria have come in as scavengers after the dry rot had produced and hastened the decay, causing a putrefactive odour. The blight is sometimes associated with the "Wet Rot" and then the sinell is overpowering.

The date of its appearance on the foliage is also subject to great variation, according to the state of the weather. I have seen the mould on the leaves of the potato plant as soon as they were through the ground, but generally it appears at the flowering season or shortly after. The name of the Late Blight is, therefore, not always applicable, for although in Britain it rarely attacks the "tops" before July or August (autumn), with us it is often much earlier, and it sometimes appears along with the Early Blight.

The most contradictory results are often obtained from experiments with one or a few potato-plants.

At Glasnevin Hodel Farm, the ground beneath diseased potato-tops was covered with a layer of cotton-wool to prevent the spores reaching the tubers, and they remained sound. The conclusion naturally drawn was that the tubers were infected by falling spores, as when precautions were taken to exclude them, there was no infection. 
On the other hand, I infected potato-tops, and although spores were produced in abundance, the tubers remained perfertly sonnd. In this instanee, without the nse of cotton-wool. I arrived at the same result, showing that experiments with single on a few plants are apt to be misleading nules carefully checked.

Finally, the most variable results are obtained in those fases where the weather exprcises ac controlling influence. Thus: a grower harvests his potatoes and finds those affected to rot away, while the other potatoeremain to all appearance perfertly somd. He at once jumps to the conclusion, and says-" The theory that Irish Blight spreads to other potatoes is entirely exploded." But when these same potatues are hagged while still noist, and "sweating" orcurs, and they are picked over on arriving at their destination, he is astonished to find that so many of his seemingly sound potatoes have gone bad. The heat and the moisture have encouraged the development of the fungus, and there is no theory, but hard fact, as he know: to his cost, ahout the discase sprearling among the potatoes.

\section{DistrubTtoN OF PPORES BY THE WIND.}

The spotes of the frish Blight fungus are produced in inmense numbers and in perfectly still air; they may fall vertically downwards on to underlying leaves or the soil. But with air currents ther are easily blown abont. and may be earried to considerable distances from their place of origin. The wind may travel several miles an hour and carry the spores with it, but since they are slowly, but steadily falling, they must sooner or later descend to the earth.

The distance to which spores may be carried by the wind has attracted a good deal of attention in Australia, not so mueh for scientifie as for commercial reasons, because Western Australia has fixed a linit of 50 miles. and all potatoes sent to that State were required to be grown at least 50 miles from a diseased area. Now there are certain limitations in the very nature of the spore itself, which must be taken into account in practically considering the distanee to whieh spores mav be carried. They are not, to begin with, like particles of dust, unaffected by heat or moisture, but they are living things, and, if lept dry for 20 hours, perish. Then, again, they are vers adlesive when detached, and whatever they strike against in their aerial rambles, they are likely to stick to. Further, they not only require moisture to germinate, but they must reach some plant of the potato family-another potato, or tomato, or kangaroo apple-in order to survive. In a potatogrowing area there is no difficulty in accounting for their distribution and spread, but beyond that they may encounter so many natural barriers, that their chance of survival and reaching a suitable host-plant is very limited indeed.

But, apart from all this, the distance to which spores may be carried mar he approximately measured in the open, by means of glass slides smeared with glycerin and alcohol, the alcohol being added to make the glycerin run more freely and be more evenly distributed. These smeared glass slides are fastened to stakes driven into the ground at measured distances from the infected crop. and after exposure for some time (2t or 48 hours), the number of spores caught on the glass plates are counted. When slides facing an infected field in the direction of the prevaling wird, after several triais show no sporeit may be accepted that the limit of their transport has been reached. Arrangements were made for carrving out this test, but the rain interfered and prevented an accurate record being made. 


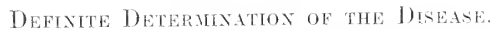

Amid the conflict of opinion between practical famers, it is excestingly fortunate that the disease generally known as Irish Blight ean be diagnosed without the shadow of a doubt, either from the leaves or the tubers, since in every sure case of it, the fungus causing it is found associated; and to emphasize this point, I may mention that having had hundreds of specinens submitted to me for my decision, I have never once determined the disease to be Irish Blight without finding the hoar-frost-like mildew on the leaves or tubers, or in the numerous instances where this was not available, by placing diseased portions in a noist chamber, to see if the particular fungudeveloped.

The fructification of this fungus is so characteristic, that there is no mistaking it, and under the microscope it is just as easy to settle it as to tell an apple, a pear, or an orange tree with the fruit upon it. Not only so, but when this same fungus is found on a tomato or a kangaroo apple (Solanum aviculare) the spores are used to infect a healthy potato in order to show whether the disease is communicable from one to the other. In contrast to this certaints based upon facts, we have the farmer offering his opinion on a matter which often does not come within his ken, unless he is accustomed to the use of the microscope, which usually he is not. To him the word hlight couveys no definite meaning. but it may be almost anything which causes the foliage of the potato to turn brown and die. This effect may be due to variouagencies, insect or fungus, drought or wet, and it is the business of the plant pathologist to assign it to its proper cause, after due investigation.

As an illustration of the different methods adopted by the practical farmer and the plant-doctor in arriving at a conclusion, I may take a supposed case of "water-rot," and the reasons actually advanced by growers themselves. The farmer observes that there is an absence of smell from the affected paddocks and, therefore, jumps to the conclusion that it camnot be Irish Blight. It is a very general impression both with the farmer and the man in the street, that you can invariably tell Irish Blight by the smell, and if that were so, why all this needless fuss about the matter. But it is a well-known fact that the fungus causing this disease produces a dry rot, and it is only when the bacteria of decomposition arrive on the scene as scavengers, provided with the necessary warmth and moisture, that the wet rot sets in, with the disagreeable smell. Potatoes affected with the disease may be firm and dry, and the leaves may become brown and dry up. On the other hand, the potatoes may become an evil-smelling mass, and I have known the plants themselves in the field to give forth an ummistakable odour. Again, it is observed that the majority of the potatoes on the higher-lying land are perfectly sound, but that is no evidence that the disease does not exist on low-lying land. The blight generally starts in low-lying damp spots, and this vear in Victoria it was found at the highest point where potatoes are cultivated. Another observation is made by the farmer, which is partly true and partly false. He notices that where the potatoes have rotted in the low and marshy ground, the rot invariably starts at one end and sprearls over the whole of the potato, whereas he considers that in the case of Irish Blight, the disease attacks the tuber around the complete circumference and works to the centre. Now, if he had followed Irish Blight in the tuber from its earliest stages, he would have found that it may begin from one end or from any part of the surface according to the point of infection (as shown in Fig. 1), although. ultimately it spreads around the circumference beneath the skin. It is a characteristic of this disease that it works from the outside inwards, and to that extent the farmer is justified in concluding that it does not show the symptoms 
of Irish Blight; but there is a want of fuality in the whole process of reasoning. some ultimate court of appeal is evidently required whose decision shall be final, because based upon the essential facts of the case.

The plant pathologist, in his investigations, visits the affected paddocks and sees for himself the conditions under which the potatoes are grown. His experienced eve may be able to tell from the nature of the decaying leaves or the state of the tubers, whether the disease is Iikely to be Irish Blight or not. But to plare the matter beyond the possibility of a doubt he secures potatoes at different stages of the disease, and by keeping them under suitable conditions for 15 to 24 homs, he can definitely decide if the Potato Blight fungus is present. (Of course, if the fungus appeared on the leaves or on the tubers, he would be able to recognise it with a magnifying glass at once.

\section{PraveNTHE MEASERES.}

since it is now well established that this disease is distributed chiefly by means of the seed potatoes which contain the mrcolium of the fungus, it is evident that if the tubers free from the disease are planted in a district where the disease does not already exist, there will be no blight. So that we have to distinguish at the ontset between districts which are clean and those which are affected, but since practically all the potato-growing districts are affected more or less, the clean areas will be simply those in which potatoes are being grown for the first time.

In the affected areas it would be necessary to get rid of every trace of the disease by the destruction of all diseased hauhns and tubers, as well as any potatoes still remaining in the gromud. To do this thoroughly, and for the rood of the industry as a whole, it would be advisable to put all land which has been under the crop the previous season, out of potato cultivation for, say, two seasons, so that all self-sown potatoes conld be rooted out and the land thoroughly cleaned.

The following recommendations, which may seem at first sight rather cumbersome, contain the principal points to be attended to in a condensed form, but for those who objert to detail, they are conveniently summed up in a single sentence at the end.

The practical measures for preventing the spread of the fungus may be summarized as follows:-

1. Seed potatoes should be saved from a clean crop, or obtained from a district free from the disease, and carried in new bags.

Potatoes for seed should be arefully selected, drying them thoronghly before storing, and keeping them separate from those intended for consimption.

2. Diseased hauhns should be collected and burnt as soon as the crop is dug, since it has been proved that sound potatoes may beconre infected by contact with such refuse. If the disease has appeared late in the season when the tubers are nearly full grown, it would be advantageous to remove the haulms at once.

When the haulms have been destroyed by blight and they are no longer green, no further growth in the size of tubers will take place, and the crop should be dug without delay.

3. "Wild" potato-plants should be promptly removed from the crop since the stalks remain longer green, as they have been known to be affected with blight when the main crop had naturally died down and was clean.

4. Diseased tubers should either be destroyed by burning or boiled before being used for pig-feeding. They boil hard with the skin unbroken. 
5. Do not plant early and late varieties alongside of eaclt other.

6. Tomatoes should not be planted with potatoes, since healthy tomatroes can be infected from diseased potatoes, and diseased tomatoes ran infect liealthy potatoes.

7. Avoid planting potatoes in immediate succession to crops affected with disease. In fact, a rotation should be adopted so that potatoes will not occupy the same ground oftener than once in three or four years.

8. Use sprouted seed for planting, since the tubers mature more quickly and are, therefore, a shorter time in the ground, and the time for planting can be better regulated.

9. Clean cultivation and keeping down of weeds is a safeguard, since there are some, such as the kangaroo apple, which produce spores in abundance and disseminate the disease.

10. It is a wise precaution to steep the seed potatoes for three hours in a solution of formalin, prepared at the rate of a 1-1b. bottle to 40 gallons of water. This will destroy the effect of any spores adhering to the surface of the potato, although it will not influence the mycelium or spawn inside.

11. When the rows of potatoes are " earthed " up, or " moulded," so that there is a greater thickness of soil covering the young tubers, there is leschance of the spores of the fungus reaching them.

12. Spray with copper-soda solution or Bordeaux mixture. The object of spraying is to prevent the development of the disease, and thus prolong growth until the tubers are fully grown. Incidentally, there is a longer period of growth and an increased rield.

Spraying of the potato-plants is such an important operation in the prevention of blight that it is specially dealt with in a succeeding chapter.

\section{Clean sead and clean cultivation, rotation of crops and spraying, and avoiding too close planting, are the best known means for combating Potato Blight.}

\section{"Steeps" for Seed Potatoes.}

There is a very general impression among potato-growers that if you steep, seed potatoes in a solution of copper sulphate or bluestone, just as seed wheat is pickled for the prevention of stinking smut, you will overcome the blight. This solution will destroy any spores on the surface of the tuber, but it does not penetrate beneath the shin and, therefore, does not reach the mycelium or spawn of the fungus inside. I carried out experiments with formalin to test its effect on both the mycelium and sporangia.

A diseased potato was cut in slices and placed in formalin (Cuming, Smith: solution) prepared at the rate of $1-\mathrm{Ib}$. in 40 gallons of water, for three hours. On the second day there was a Iuxuriant growth of $P$. infestans, thus showing that formalin of that strength does not destroy the mycelium inside the tuber.

Sporangia were placed on a microscopic slide in a solution of formalin of similar strength to the above. They were watched continuously for five days, but no germination occurred, while sporangia from the same potato, but placed in water, produced zoospores in great abundance. Sporangia placed on the microscopic slides produced their zoospores in water in less than an hour, and in every slide the zoospores were observed swimming about. These zoospores came to rest, and ultimately germinated freely. 
While formalin does not destroy the internal mycelium of the fungus, it prevents the sporangia developing further, and since they may happen to be in the surface of the tuber, I recommend dipping in formalin as an extra precaution against the Potato Blight.

Potatoes were steeped in a solution of bluestone at the rate of $1-1 \mathrm{~b}$. in five callons for one quarter of an hour, and this treatment did not interfere with their growth.

\section{Prevention of Potato Befght by spraying.}

In the leaflet issued by the Department of Agricnlture and Technical Instruction for Ireland on the Prevention of Potato Blight, the value of spraying is shown in the results of experiments, and the following statement regarding its utility is made:- "The experience of recent vears has conclusively proved that the loss caused by Potato Blight can be, to a great extent, prevented by spraying-an operation which has now conne to be regarded as an essential part of the work connected with the suceessful (ultivation of the potato crop. The reports received by the Department from a large number of districts show that those who take the trouble to carry out the work properly are abundantly rewarded, while those who neglect to spray suffer heavy loss, both in the quantity and quality of the (rop."

As the result of eighteen tests conducted by the above Department, there was an average increase of $2 \frac{1}{2}$ tons per acre from sprayed over unsprayed plants with eopper-soda mixture, and in fifteen tests with Bordeaux mixture the average increase was nearly $1_{4}^{3}$ tons per acre. The increase is due not. altogether to the suppression of fungus, but partly to the beneficial effect of the spray on the nutrition of the plant.

It is not, therefore, surprising to find that the practice is becoming more and more common as its advantages are realized, and the latest official report states:- "Some idea of the recent progress made in this matter of spraying may be gained from the fact that during the last three rears nearly $t, 000$ spraying machines have been sold through the efforts of the Department in the congested districts of the west of Ireland alone."

The efficacy of spraying is no longer called in question by any one who has given it a fair trial, but for those who have suffered severe loss in their potato crops during the past season, the following facts, gleaned from local experience, should convince them that it pays to spray. In the minds of many, the weather is the controlling factor, but during this season, which has been the worst on record for the encouragement of fungus diseases, the results obtained both with Black Spot of the apple and pear, and Irish Blight of the potato show conclusively that spraying done thoroughly at the proper time and with the proper mixture, saves the crop in spite of the weather. Since the leaves of the potato-plant are rough and hairv, the spray requires to be forcibly applied in order to reach every portion of the surface.

About the middle of February a local grower sprayed $t$ acres of potatoes with the copper-soda solution by means of a motor pump, when the tops were luxuriant, using 70 gallons to the acre, and reckoning the cost of labour and all materials at $7 \mathrm{~s}$. $6 \mathrm{~d}$. per acre. They were again spraved in about a fortnight, and the result is given in the following communication.-

"Although I have blight on my farm, the sprayed potatoes are remerhably free from it. I have just dug a hundred bags, and there was not on: per cent. infected, and a strip not five chains away-a few rows that I did not spray-are completely rotten. The disease in this district is in a most 
virulent form, the hot, misty, muggy weather made a heart-breaking mess. of things, the disease appearing simultaneously over a very large area, hardly missing a farm, and leaving ruin everywhere."

Kirchner, in Germany, has carried out spraying experiments with very variable results. In 1897 , potato plants were sprayed four times with a 2 per cent. Bordeaux mixture, and if the yield of the unsprayed plots is represented by 100 , the average of the sprayed plots was only $69 \cdot 4$ per cent. of tubers, and $68 \cdot 4$ per cent. of starch. It is assumed that the Bordeaux mixture acted unfavourably on the production of starch; but here again the weather factor has to be taken into account, for the summer of 1907 was very cold and cloudy, and the investigator doubted whether the same results would be obtained during a bright, warm season. In all these cases the nature of the seed planted has not been taken into account. It is too often assumed by the farmer that he does not need to be too particular about the selection of his seed, especially when he sprays to prevent the disease. But it has been already shown, and it is here emphasized that if diseased "sets " are used, the spraying will not be so successful, apart altogether from the quality and the extent of the yield.

The good effects of spraying, even when done rather late in the season, were shown in the experimental plots at Kardella, planted with badly-blighted seed potatoes. It was originally intended to spray a few rows with the copper-soda solution; but it rained so heavily on the date of our visit for this purpose, that it had to be abandoned. However, on 6th March, two rows were sprayed, whell the tops were badly blighted, but still partially green, mainly to see the effect of the spray on the foliage. It rained heavily just before the spray was applied. About a month afterwards (3rd and 4 th April) the potatoes were ready for digging, and the sprayed rows were conspicuous from the greenness of the foliage, while the others were brown and withered. The spray was still visible on the leaves of many of the plants, although a considerable amount of rain had fallen since the time of application.

Two sprayed and two unsprayed ruws were selected alongside each other, in order to test the proportion of diseased tubers in each, and after digging and weighing, the results were as follows:- Sprayed 55 per cent. diseased, unsprayed 81 per cent., thus showing 26 per cent. healthy tubers in farour of the sprayed portion.

Eight unsprayed rows were next dug and weighed, and 81 per cent. were found to be diseased.

The proportion of diseased tubers in a number of rows was so consistent that the above figures may be taken to represent the gain due to spraying even so late in the season, viz., 26 per cent.

There was a considerable amount of "wet rot" present, but this was so frequently associated with the blight that no distinction was made.

It is the intention of the Department to conduct spraying experiments in different districts, so as to show the effects produced when properly done. A number of growers have sprayed this season without obtaining any definite result, but this could usually be traced to some important omission. There was either a want of thoroughness in not spraying the under as well as the upper portion of the foliage, or the force applied was insufficient. Besides, it was a very rainy season, and the mixture was sometimes applied but afterwards washed off. The copper-soda solution has great adhesive power, and at Kardella it was found still adhering to the foliage a month after the application, even although there had been frequent rains, but spraying should not 
be done when it is raning. The now-born zeal for spraving was not alwars areording to knowledge, and as Newton has said, "zeal without knowledge is like expedition to a man in the dark." Some growers confessed to having sprayed ten to twelve times, moder the mistaken notion that if plenty of the solution was used frequently, it was immateral as to the method of application. The type of spraying marhe ased is very important, and this, together with the best time and unthod of application of the spray, will be clearly demonstrated next potato spisons.

The puestion is often asked, "Should the spray be applied to both the upper and under surlaces of the foliage ?" and the answer depends on the view taken of the action of the spray. If it actsimply as a protective coating, then the more thoromghly the surfaces are covered the better. But if, as some think, the spraying material is partially absorbed, then sprayines on one side, and particularly the upper side, would serve the purpose. It will be necessiary to conduret experiments to settle the point, spraying the upper, the under, and both surfaces by means of a knapsack sprayer and noting tlen results.

\section{Sulphate of Copper and IItashing Somda lierommernded as a Spray.}

The spraying mixtures recommended are either of the two following :-

1. Sulphate of copper or bharstone, and washing soda.

2. Sulphate of cofperer and lime.

The former is recommonded ly preference for the following reasons :-

1. It adtieres fongere to the lobliage of the plants, and is not so readily washed off by rabin.

2. It is more aibily prepared.

3. It is not so liable to clog the nozzles of the marhine, because if the mixture is carefully prepared there should be no sediment.

\section{Proparation of the Mixture.}

The mixture is made in the following proportions:-

$$
\begin{aligned}
& 8 \text { lls. sulphate of copper. } \\
& \text { lo Jhs. wishing soda. } \\
& \text { fo gallons water. }
\end{aligned}
$$

The sulphate of copper is dissolind in a barrel or wooden tub, because the solution has a corcosive action on metal. Pour into the barre] 35 gallons of clean water. If there is any grit or foreign naterial in the water it should be strained through in piece of hessian, so that it does not clog the nozzles of the sprayer.

The 8 Hos. o[ sulphate of copper' should be tied up in a piece of hessian and moved about in the water in the barrel until the crystals are all dissolved. 'The operation is hastened if the crystals are previously ground.

Next dissolve the 10 lbs, of washing soda in five gallons of water in a separate vessel. Then pour the washing soda solution slowly into the copper sulphate solntion in the barrel, stirling continuously, and the mixture is ready for use. Il comvenient to have hot water, both the sulphate of copper and the washing soda can be more puickly dissolved, and the required quantity of cold water can afterwards be alded. A quarter of a pound of Paris green may be added to the 40 gallons il it is desired to destroy grnbs as well. There is no harm in dissolving the sulphate of rofper and washing soda in separate ressels 


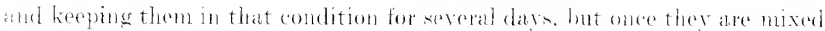
together, the mixture should he applied immediately. The mixturedeteriorates. rapilly exen when held ovel for one day. and is then mexh more rearlib
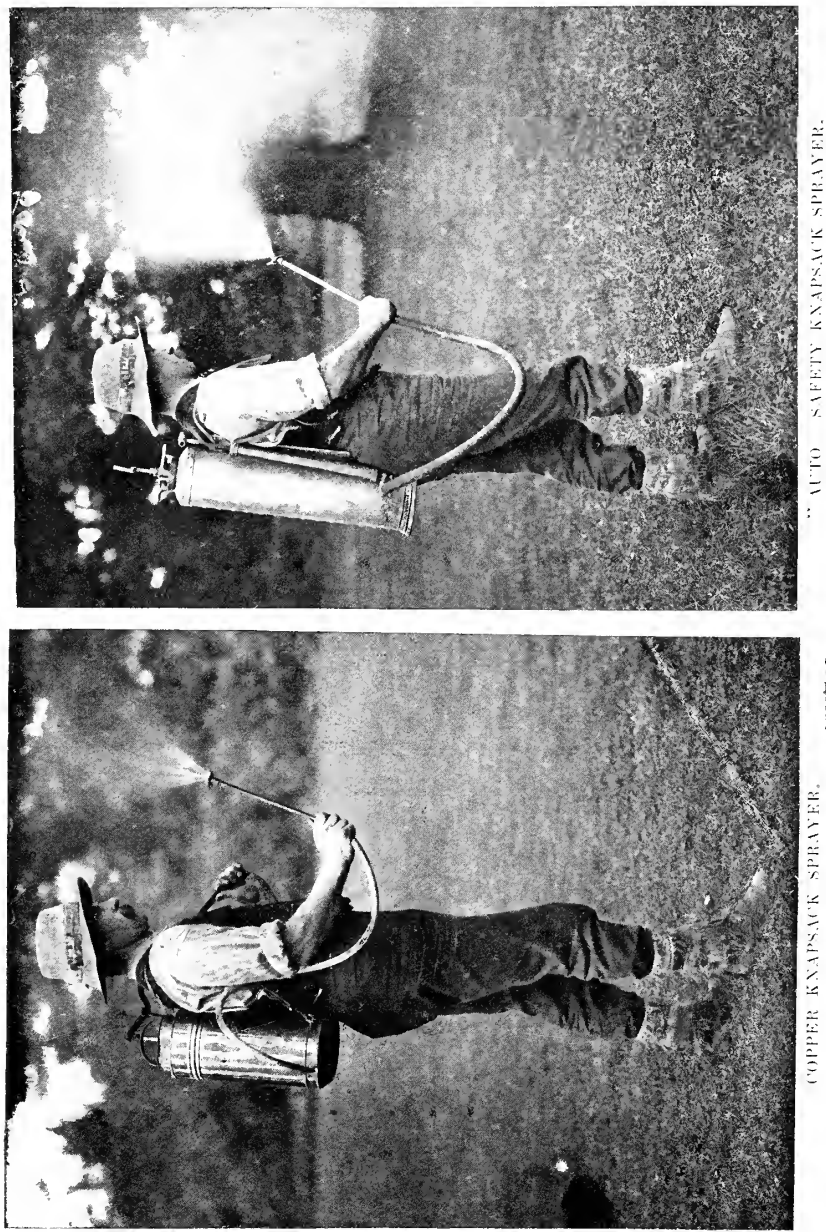

washed off the plants by rain. The freshly-made mixture should alwars be used. Sulphate of copper is poisonous, therefore the vessels in which the mixture has been prepared should not be used for holding food or water for consumption. 


\section{Ipplication of the Nintuie.}

Spraying should he done hefore any signs of the disease have appeared. It is desirable to apply the fir dresing when the plants are about six inches high, although leaves are sometimes blighted as soon as ther appear above ground. A second spraving whould be grven when the foliage is well developed, and if the season is a wot one: a third dressing may be adrisable. It is the experience of potato-growers generally that there are two periods in the life of the potato-plant, when it is most easily infected by the Irish Blight fungus. The first is while it is stiil roung and tender and growing rapidly. and the second is when the tissues are fully formed and the flowering stage has been reached. It in a well-known fact that the tissnes are much more susceptible when growing than when full formed: but to counterbalance that, although the tiswuen have rearhed maturity in the second stage, the plant is particularly rich in food substances on their way to the tubers. If dull, wet, muggy weather sets in at this period, the fungus revels in the rich supply of food and spreal throughout the plast with amazing rapidity, which is reduced to a black, decaring, foul-smelling condition within twentyfour hours. The foliage should be completelr covered by the spray in the form of a fine mist, and this in best done when a sufficiently high pressure is maintained in the spraver. spraying should be done during dro weather and suspended whon it in raining. If heary ran has washed the mixture largely off soon after spraying, then it should be repeated.

It is essential to success that the spraving material is kept intimately .mixed by constant agitation during the operation.

\section{Quantity per Acre and Cost of Materials.}

It is found in Ireland that an areage crop with fully-dereloped foliage requires about 100 gallons per acre, and with a small amount of foliage the quantity would be less. The quantity will vary, but the main point to be attended to is to use sufficient to completely cover the foliage without drenching the ground.

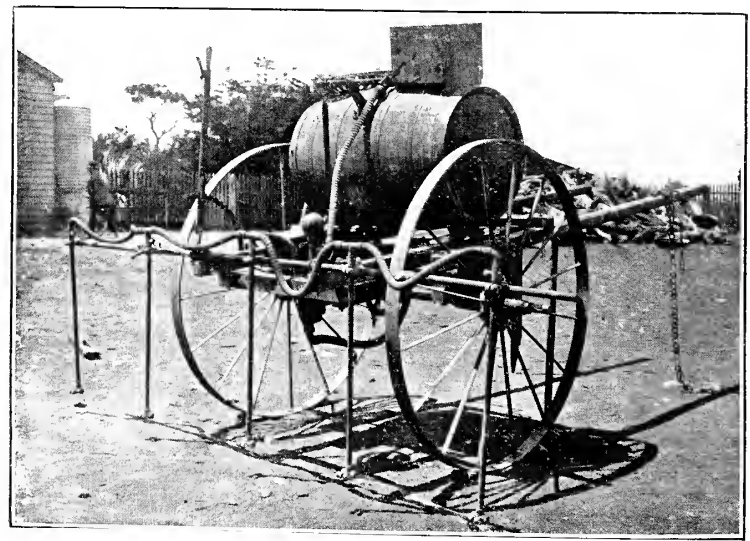

FLEWIAG' HORSE-POWER SPRAYER. 
At the present market price of the articles when bought in quantity, the cost of the raw materials of spraying an acre would be as follows:-

sulphate of Copper, $20 \mathrm{lbs}$. at 21.031 . 1rer $1 \mathrm{~b} .=4 \times .7 \mathrm{~d}$.

Washing soda, 2511 s. at $0 \frac{2}{3} d$. per $1 \mathrm{~h} . \quad \ldots=1 \times . .5 \mathrm{~d}$.

Totrl 6s. 01 .

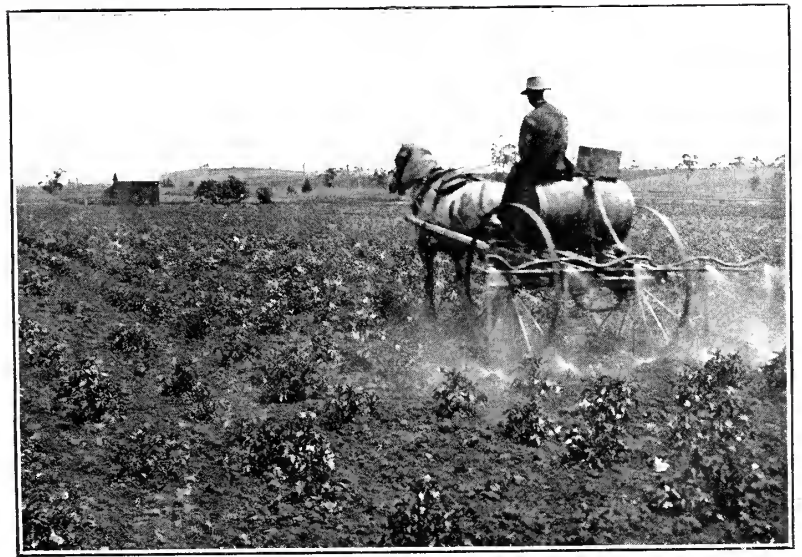

SPRAYING WITH THE FLEMING MAGHINE.

\section{Hoburn Bordeaute Paste.}

In the Journat of the Inpartment of Agriculture and Technical Instruction for Ireland. April 1911, results of spraving experiments are given, and since, during 1910 , the Potato Blight was very virulent, it was regarded as " almost ideal for the testing of spraying materials." All the plots were sprayed at the rate of 120 galloms per statute acre at each spraying, and the materials used were lime Bordeaux, limewater Bordeaux, in the form of Wobum paste and copper-sodasolution. The Wobum paste was used as recommended, at the rate of $15 \mathrm{lbs}$. per 100 gallons of water. There were four centres, and at three of them two spravings were given, and only one spraying at the fourth. In every case the hanlms died down sooner in the plots sprayed with Woburn paste than those sprayed with copper-soda solution, and, on the average of the four centres," the plots sprayed with the copper-soda gave 23 cwt. of saleable potatoes more, and 3 cwt. of diseased potatoes per statute acre less, than the plots sprayed with Wobum paste." Famers were therefore recommended to prepare their own mixtures, owing to the increased yields, and the greater protection against the blight thereby secured.

\section{Field Trial of Spraying Wachines.}

In order to show the sprayers at work, several of the best machines were tested at Bungaree. They were of various pattems and prices to suit the small as well as the large growers. There is a knapsack spraver adapted for areas of only a few acres; and a powerful machine, such as the motor spray pump, which can be used for spraying the most extensive plantations as guickly as possible. 
The larger machines were charged with th gallons of the ropper-sodat mixture and the application of the spray, together with its regular distribution over the crop, was closely followed by over 200 famers. Ear.h machine sprayed five rows at a time and 100 gallons would cover from 1 to $1 \frac{1}{t}$ acres. Of course, more extended trials would be necessary to test the capabilities of each machine for spraying cheaply, quickly, and effectively, and no attempt was made to place them in order of merit, although the performances of each were keenly discussed.

The following machines were exhibited in action, and the accompanying photographs will give a good idea of their general structure and mode of working.

1. Knapsach Sprayers. - I copper Knapsack sprayer is shown, capable of holding 5 gallons and is to be preferred to one made of gatranized iron, because the iron extracts the copper from the mixture and thereby render: it less efficacious. The cost is from $£ 3$ upwards.

The other represented is known as the "Auto" safety" spraver, and is made of galvanized steel, with asphaltum paint inside. The cost is $£: 3$ for 2-gallon size and $£ 6$ for : -gallon size.

2. Fleming's IIorse-pouer Spraypr.-Tis is a comparatively light machine, as the weight is about 10 cwt. when the barrel is full. The wheels can be moved in or out to snit the width between the rows. The spray never comein contact with iron, as it passes through brass, armoured hose and a copper tube. The armoured hose is warranted not to collapse. By means of a couple of levers easily controlled. the sprays are lifted at the end of the row and the mixture is, at the same time, cut off at the tank. As soon as the

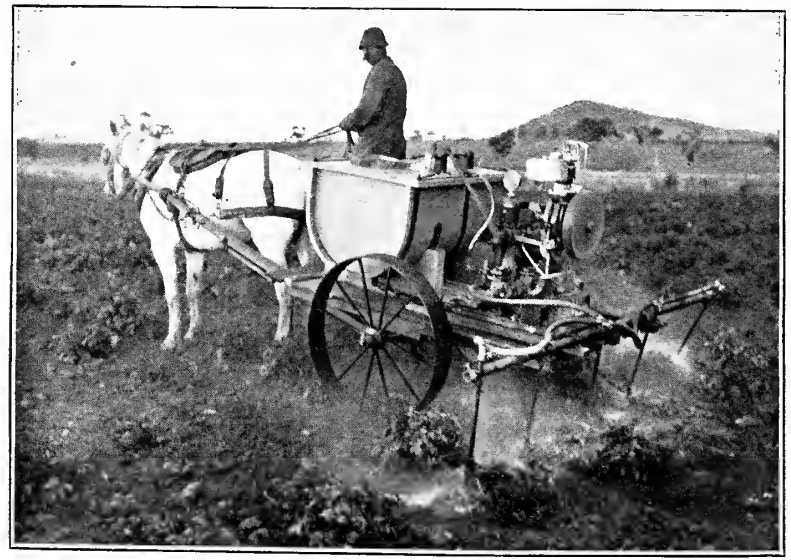

L. B. \& D. MOTOR SPRAYER.

machine is in position for spraying the next set of rows, the levers are reversed and a tresh start is made. Duplicates of the different parts are kept in stock; so that they are easily replaced when necessary. The complete cost is $£ 30$.

3. L. B. and D. Motor Sprayer.-This consists of an engine, pump and vat. The engine runs at jon revolutions per minute, and has a pressure 
from 1.50 to $300 \mathrm{lhs}$. It is fitted with a governor, which enables it to run at any desired speed, and has a magneto instead of a battery. The engine can be completely disconnected in five minutes, and mav be used for other work, such as chaff-cutting, pumping water, \&c. Cost of the engine, $₫ 36$.

It is attached to two 21 -in. plungers, and the pump has a triple agitator. The droppers of the spraver are on the stump-jump principle and have also gnards to protect the spraver. The vat is $\mathrm{I}^{\mathrm{T}}$-shaped to allow of thorough mixing of the ingredients. It holds 80 gallons, and when fully charged the entire weight is abont one ton.

Cost of engine, pump and sprayer, $£ 67$ 104.; and if monnted on a cart as in photograph, £77 10s.

4. The Forbes Sprayer.-This machine is made at Bungaree, and when harrel is full, containing 100 gallons, weighs 17 cwt. It is built on steel

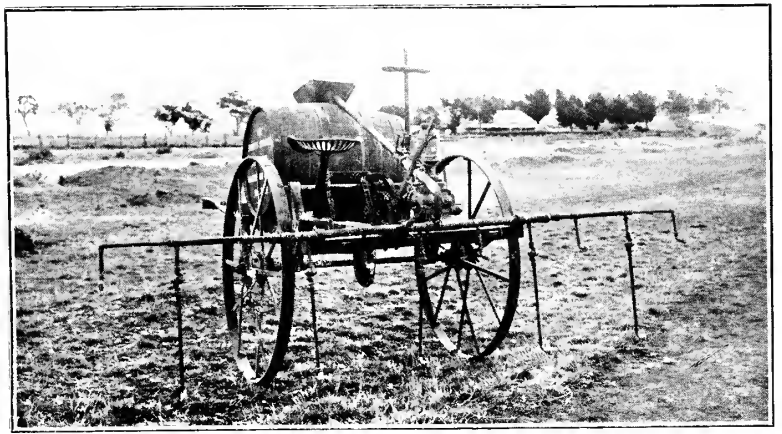

FORBES MORSE-PUWLR SPRAYER,

wheels with steel axle adjustable, a!so fitted with ratchet gear for turaing, and driven with chain from centre of axle off sprocket wheel. The pump is

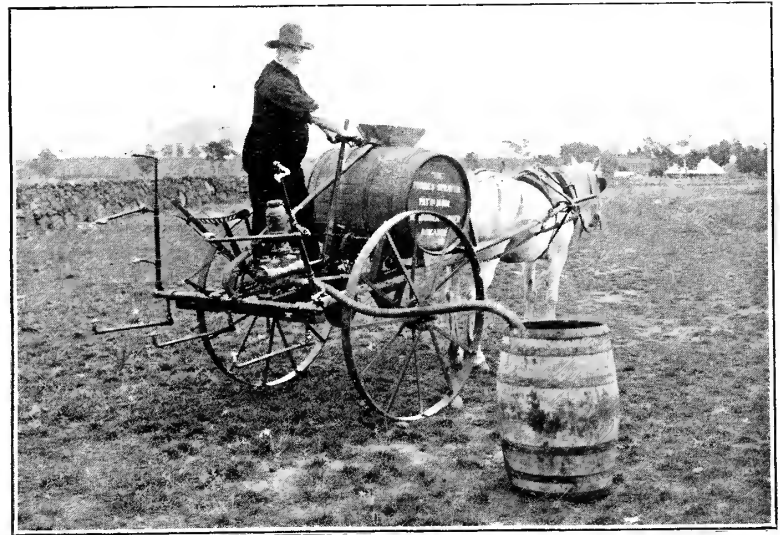

FHITNG DARREL OF SPRIYER HS FORCE PTIP. 
driven with eccentric and can be used to fill the barrel instead of bucketing, thus saving time and extra help. The pump is brass lined, double action and fitted with air-chamber, a continual stream of water being forced back into the barrel; the solution is thus kept well agitated. The machine is

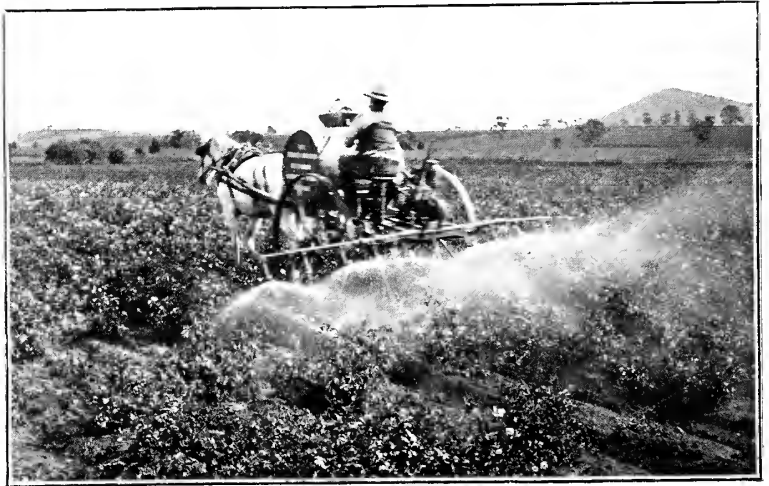

THE FORTES SPLIYYR AT \#ORK

adapted to do 5 or 7 drills at a time, and the nozzles are adjustable. The spray is circular and can be regulated to any angle. The droppers of the sprayer are fitted with swivel joints and are not injured by striking any obstacle.

Every machine is thoroughly tested before being sent from the factory and the complete rost is $£ 30$.

The machines are manufartured or sold by Messrs. Langwill Bros. and Davies, Melbourne; Messis. Edwards and Mefrimness, Melbonrne; and Mr. W. H. Chisholm, Bungaree.

\section{Disinfectiox of the Seen Potatoes by Meaxs or Dry Heat.}

While it is generally recognised that the Potato Blight is largely dependent on the weather for its derelopment and spread, yet there is something which has to pull the trigger before the gun will go off, something which affects the plant in the particular way characteristic of this disease, and that is the Tungus Phytophthora infestans. Whenever the fungus origin of the disease is clearly understood, and that the weather alone cannot produce the symptoms, then we have something definite to deal with in seeking a remedy or some means of prevention.

After a thorough study of the life-history of the fungus, and the conditions under which each of its stages passes its existence, pathologists have cone to the conclusion that the two main lines of attack are (atways presuming that clean "seed" in clean ground at a proper distance from affected areas is the first line of defence) either to prevent the formation of spores in the aerial portions of the plant by spraying, or to destroy the spawn, or mycelium, in the seed potatoes by dry heat.

These are the two alternatives at present, and while spraying at the right time is an undoubted means of saving the crop to a large extent, yet it does not get rid of the disease. Heat, on the other hand, is used to stamp out the disease, because it destrors the cause of it in the seed potato itself. 
Of course, if a guarantee could be given that only clean "seed" was planted in infected districts in fresh ground at a sufficient distance from a blighted area, and that no potatoes were grown, say for a eouple of seasons at least, in the fields in which Potato Blight had been found, there would be no necessity for using heated seed. But there is always the risk that reputed clean "seed" may be shightly affected, so that not even an expert could detect it on a cursory examination, and dry heat is therefore being tried for stamping out the disease under the conditions which prevail in Fictoria.

There are various liquid disinfectants used as "steeps," but these can only affect the outside of the potato. The corky skin of the potato is impervious to moisture, and even where the skin is broken by the eel-worm, there is a corky skin formed beneath the wound (as shown in Fig. 56).

Both sound and "scabby "potatoes were steeped in formalin and corrosive sublimate respectively, and even after being in the liquid for four hour there was no penetration beneath the skin. Steeped in a solution of iodine for some time, which gives a blue coloration to starch, there was no rhange of colour produced when the skin was broken.

But it has been proved that the mycelim inside the tuber is sterilized when subjeeted to a dry heat of not less than 120 degrees Fahr. for four hour: without interfering with the growth of the potato. Not only have diseased potatoes been repeatedly subjected to a certain temperature for the necessary time with the consequent loss of power of the mycelium to produce a fructification, but the virility and vitality of the fungus have also been destroyed, as shown by its inability to produce infection in a sound potato, as it usually does when inserted beneath the skin and kept moist.

\section{The Application of Dry Heat.}

The discovery that dry heat prevented the development of blight was made quite aecidentally about 1855 , although it was only published as a remedy for the potato disease in 1861. A certain Professor Bollman received some seed potatoes for trial, and they happened to be stowed away on the back of the stove used for heating his study, and forgotten. They were afterward: found shrivelled up, and as a matter of curiosity were planted in 1855 to see if they would grow. They produeed a crop with all the good qualities elaimed for them, and next season were heated and again planted. It was observed that while surrounding potato-plants were affected with blight, those from heated seed were free from it. In 1857 , a larger plot was planted, with the same result, and the professor had then a drying-floor ereeted on his estate for the heating of potatoes on a large scale before planting.

The exact temperature to which the potatoes were subjeeted was not stated, and there is no eonelusive proof that the dry heat destroyed the disease, yet the ereetion of drying-kilns showed that the heat was believed to produce that effect.

The next reeord of the application of heat is by J. L. Jensen, of Copenhager. as given in the Gardeners' Chronicle for 188t. "It is shown there that it is possible to kill the fungus in tubers, without injury to the germinating power of the potato, by means of dry heat.

The experiments were carried out in 1883, as well as subsequently, and the conclusion given in Jensen's own words is " that to kill the mycelium the tubers themselves must have acquired and maintained the temperature of at least 40 degrees C. (104 degrees Fahr.) during four hours." He also found that sporangia were not formed at a temperature of 77 degrees Fahr. It may be asked why, if the process of disinfection of seed potatoes by means of is dry heat raised to 104 degrees Fahr. inside the tuber has been definitely 
known for over half a century, it has not been adopted in practice. This is probably owing to the difficulty of treating potatoes on a large seale, for while Jensen gives a drawing of a convenient apparatus for treatment on a small scale, consisting practically of a water-hath, he adis-" On a large scale this may be done in a properly constructed oven where the temperature is careEully watrhed during the whole time."

As the resnlt of numerous experiments during 1909-10, it has been found that a dry heat, not less than 120 degrees Frinc, and not more than 130 degrees Fahr., destroys the vitality of the spawn in the tuber without injuring the growing power of the potato.

This has been tested practically, not only on a small scale in a water oren, but on a large scale in a fruit-drring plant. Healthy potatoes so treated have been grown at Bumley I Iorticultural Gardens, and diseased potatoes in a quarantined area.

In the heating tests it was observed that seed potatoes dug late stood the heat much better than those dug early in the season.

\section{Experinexts with Heaten axp Lxheated semp Potatoes at Beraley.}

Although I have demonstrated conclusively on a small scale that potatoes affected with the Irish Blight fan be heated. and the spawn of the fungus destroyed without interfering with the glowing power of the potato, it is necessary to show that the process can be caried out on a commercial scale, if it is to be generally adopted by the grower. The grower has to be convinced, first of all, that heating the potato to a certain temperature will not "cook" it, as he expresses it. Accordingly, at the Burnley Horticulturat Gardens, with the co-operation of the Principal, I was able to grow heated and unheated potatoes side by side.

Five varieties of potatoes, viz., Coronation, Cp-to-date, Clarke's seedling, Fox's seedling, and Caman No. 1, were heated on 25th July, 1910, in the disinfecting apparatus. They were heated for four hours, and the temperatures recorded were as follows:-

$\begin{array}{llll}\text { Start } \ldots & \ldots & \ldots & 120 \text { degrees Fahr. } \\ \text { End of 1st hour } & \ldots & \ldots & 126 \text { degrees Fahr. } \\ \text { End of 2nd hour } & \ldots & \ldots & 126 \text { degrees Fahr. } \\ \text { End of 3rd hour } & . & \ldots & 126 \text { degrees Fahr. } \\ \text { End of th hour . . } & \text {. } & 126 \text { degrees Fahr. }\end{array}$

The internal heat of the potato reached 117 degrees Fahr.

The heated potatoes were planted alongside unheated potatoes of the same variety on 28 th July. The result was that the heated potatoes germinated equally well with the unheated. Ther were all dug on 30 th December, and the potatoes from heated and unheated plots were equally good.

Having shown that potatoes can be heated to a certain temperatura and grow freely, the next step was to carry out experiments on a small scale with blighted potatocs that had been heated.

In a bird-proof enclosure at Bumley Gardens, used for wheat exper:ments, blighted potatoes that had been heated and derived from different sources were planted. Irish Blight had not appeared in the Gardens, so that there was no danger of infection from wind-borne spores. They were all planted on 19th September, 1910, in ground where wheat had been grown the preceding year, with the following results:-

1. Two potatoes were planted, but only one came up and grew luxuriantly, quite normal and healthy. On 24th. January, 1911, the potatoes were dus, and the yield was 20 maketable and 26 small. They were perfectly healthy, and no sign of blight appeared in the tops or tubers. 
2. Five potatoes were planted similarly, and four of them grew up quite healthy and produced potatoes which were quite sound. The odd one did not grow.

3. Seren potatoes of the Factor variety were also planted, and every one of them grew up healthy, producing sound tubers.

4. Two potatoes planted only produced one healthy plant, the other "set" having rotted. Six sound potatoes were produced by the one healthy plant.

Here were four distinct tests of planting blighted potatoes that had been heated, and no blight appeared in the plants or their produce. In every case similar potatoes to those planted, but unheated, were kept in a moist chamber and developed the fructification of the fungus.

It may be contended that the spawn of the fungus, even although alive, did not reach the growing part of the seed potato, but why in every one of the four rases tested.

It is also held bv some that blighted potatoes when planted either produce healthy plants or none at all, but experiments now to be considered will show the fallary of that statement.

\section{Experimexts With Heated and Unheated Blighted Seed Potatoes at Kardella.}

It only remained now to arra'ge for heating blighted potatoes on a large scale, and for planting both heated and mnheated diseased seed in a quarantined area. A fruit-drying factory at Harcourt seemed the most convenient for the purpose of heating.

There was some delay in securing the necessary land at Kardella, and there was no time to prepare it thoroughly if the planting was not to be carried out too late in the season. The grass paddock obtained for the purpose was cleared about fifteen years ago, but had never been eultivated. This was the first time it had been broken up, and the potatoes were simply planted in the furrow made by the plough and then covered over with the soil. It was the usual gray soil, common in the district, and the nearest planted potatoes were fully ha!f-a-mile distant.

The blighted potatoes used for the experiment were very bad indeed, and had been sent to the destructor. Over one acre was planted altogether on 7th November, 1910, with blighted potatoes heated and unheated, and the "seed" was of such a nature that no one would ever dream of planting it, except for experimenta] purposes. There was only a strip of land six feet wide separating the two plots, and this was planted with rye which, however, grew very thin. It was intended to have a dense, close growth to prevent the spores from the untreated plot reaching the other, but as it turned out it was no protection at all. The plots were examined on 27 th January, when the plants were in flower and the tubers forming. Both the heated and unheated seed potatoes produced luxuriant tops, the plants all appeared quite healthy, and at this stage there was not the slightest external sign of blight.

The blight was first visible on the leaves on 21 st February, and a thorough examination of the rows on 27 th February showed that every plant was affected more or less on both the plots grown from heated and unheated seed. The plants were still green, but the leaves in every ease were producing abundance of spores, and sometimes the stems as well. The tubers were also examined, but no trace of blight was found. Hundreds of kangaroo apple plants (Solanum aviculare) had grown up among the potatoes, and they had evidently been infected with wind-borne spores, for almost every one was blighted, and the leares, stems, and young tops bore abundant fructification. (Fig. 119.) 
Lufortunately this expcriment on a commercial scale, as far as the effect of heating blighted tubers is concerned, is inconclusive, since the plot grown from heated seed could easily be infected by spores from the adjoining crop grown from diseased seed, and the farmerinforms me that the prevailing wind is from the unheated towards the plot grown from heated seed.

It will be necessary therefore to repeat the experiment at next planting scason, growing the heated sced in some isolated spot where there is no possibility of infection from outside sources, just as it would be in a district where all the "sced" potatoes were either clean, or all were treated to destroy the spawn of the fungus inside the tuber.

I am indebted to Mr. Comall for the rainfall at Kardella. He has recorded the arerage for 23 years, which varies from the lowest, $35 \cdot 70$ inches in 1908 , to the highest, $59 \cdot 56$ inches in 1889 . The rainfall for the six months covering the period of planting and growtl of the potatoes up to the end of April in:-

\begin{tabular}{|c|c|c|c|}
\hline Torember & . & $\cdots$ & $3 \cdot 8.5$ inches \\
\hline December & . . & . & t.39 inches \\
\hline Jantuary & . & . & \rfloor$\cdot 02$ inches \\
\hline February & . & $\ldots$ & $3 \cdot 86$ inches \\
\hline March & $\ldots$ & . & $\tau \cdot 21$ inches \\
\hline April & . & . & $3 \cdot 22$ inches \\
\hline
\end{tabular}

The nature of the season during this period was beau-ideal for the blight, bing thundery, showery, and steany. The official remarks are:- "Much more thunder than the past few years, with nuggy atmosphere, coo. periods, and very little dry and clear hot weather."

It lias been suggested that secd potatoes might be exposed to the natura? theat of the sum instead of being subjected to artificial heat, but it will be evident that the temperature cannot be regulated under these circumstances, so as to prcvent it rising too high and thereby possibly interfering with their srowth.

As already pointed out, the only known means of stamping out or exterminating the Potato Blight in a district is by means of dry-heating the seed potatoes to a temperature of not less than 120 degrees Fahr. for four hours. This heat does not destroy the growing power of the potato, while it kills the spawn inside, as has been proved by experiments several times repeated. If the system is to be a success, it would be necessary to heat all the seed potatoes for a potato-growing area, because the wind-borne spores might infect an otherwise healthy crop, as at Kardella, and of course they should bo planted in fresh ground so that self-sown potatoes would not appear.

As regards the arrangements for heating, I am informed by Mr. W. French, Engineer-in-charge at the Doncaster Cool Stores, that the mechanical difficulties could be overcome by placing electric radiators in a special room, so that they would distribute the heat evenly, and the uniformity of the temperature could be controlled. With two adjoining rooms thus fitted up and provided with movable trays all round, the potatoes could be heated and cooled down in the one, while the other was being heated up.

\section{Constitutexts of the Porato.}

The most important constituent of the potato is starch, which may reach hercentage of 18 to 20 in the best varieties, and the water content on a 1. wrerage is about 75 per cent. In order that the potato may sprout or germinate, this insoluble starch must be converted into soluble sugar, and the ferment or enzyme which produces this change is known as diastase. 
It is interesting to observe that while the healthy tissue of the potato is acid, the brown tissue permeated by the mycelium of $P$. infestans is alkaline, as well as the scab on the surface. In the internal or brown fleck, however, the brown tissue is acid, like the normal.

Before any practical steps can be taken in the treatment of seed potatoes by means of dry heat for tlie preventing of blight, it is necessary not only to know the heat required and the time it must act to destroy the spawn of the fungus in the potato, but also the effect of different temperatures on diastase, for if that is destroyed the potato will not grow. In Jost's Plant Physiology (1907) the latest results are given as follows :- "At 0 degrees C. the dissolving action of diastase on starch is scarcely noticeable; an increase in temperature is followed by a rapid incresse in its activity, until at 50 degrees C. (122 degrees Fahr.) it reaches a maximum maintained till 63 degrees C. (145 degrees Fahr.) is reached; if it be heated still further, the astivity of diastase again deereases, until finally, at about 85 degrees C. (185 degrees Falır.) its power becomes destroyed."

It is found by experiment in the field that the potato still grows freely after being subjected to a dry heat of 120-130 degrees Fahr., and this is the temperature which stinulates the diastase to its greatest activity.

The loss of moisture in potatoes so heated was carefully tested by $\mathrm{Mr}$. Seott, Chemist to the Agricultural Department.

Six potatoes were selected and weighed before heating, and the same were then lieated to 120 degrees Fahr. for four hours, with the following results :-

\begin{tabular}{|c|c|c|c|c|c|c|c|c|c|}
\hline & — & & & Before $\mathrm{H}$ & ting. & $\begin{array}{l}\text { Heated to } \\
\text { for } 4 \text { lo }\end{array}$ & r. & Toss due to & Heating. \\
\hline 1 & .. & .. & . & $52 \cdot 2.500$ & rams & $51 \cdot 7745$ & rams & $\cdot 4755$ & rams \\
\hline & . & . & .. & $48 \cdot 3.00$ &, & $47 \cdot 7.530$ & , & .5970 &, \\
\hline & .. & . & .. & $51 \cdot 1300$ & ", & $50 \cdot 6425$ & ," & $\cdot 487.5$ & ", \\
\hline 4 & . & . & . & $51 \cdot 815.50$ & , & $51 \cdot 3360$ & ,. & $\cdot 5290$ & , \\
\hline 5 & . & . & $\ldots$ & $41 \cdot 2310$ &, & $40 \cdot 8275$ & , & -4035 & ," \\
\hline 6 & . & . & . & $53 \cdot 4915$ & ," & $52 \cdot 95.50$ & & .53625 & ", \\
\hline & Total & .. & .. & $298 \cdot 3175$ & rams & $295 \cdot 2885$ & rams & $3 \cdot 0290$ & grams \\
\hline
\end{tabular}

The average loss of moisture from the heating process was about half a gram for each potato, and when six potatoes were pulped they yielded $77 \cdot 7$ per eent of moisture. (Plates I., II., III., IV., V., VI., XXXII., XXXIII., XXXIV., XXXV.,
XXXVI., XXXVII., XXXVIII.) 


\section{EARLY BLIGHT, OR LEAF SPOT.}

\section{(Alternaria solani (E. and M.) Jones and Grout = Macrosporium tomato Cooke.)}

This is a disease which affects the leaves and stems of the potato, and is generatly known as Karly Blight, because it appears just when the tubers are beginning to form, or even earlier if the conditions are unfavorable to healthy growth, in contrast to the late or Irish Blight, which does not usually appear until comparatively late in the season. The names, however, do not hold good under our conditions, for the so-called early and late blights may attack the potato at the same time. Leaf-spot is a more expressive name, as it indicates the appearance presented by the leaves when the disease is present, and since the affected leaves often curl inwardly, the term leaf-curl is also applied to it.

The disease first came under my notice in South Gippsland in April, 1896 , and now it is very common and the cause of serious loss. It is widely distributed in the United States, where the cause was first definitely determined in 1891, and is also well-known in Enrope and New Zealand. It is also known in India where, however, it does not seem to do mueh damage, according to 1)r. Butler, Cryptogamic Botanist to the Government of India, who writes:- "In India there is no indication at present of its becoming a dangerous pest, though I have on many occasions found it hastening the destruction wrought by Phylophthorn."

\section{SYYPTOMS ON THE MISEASE.}

There is no mistaking this disease when fully developed, although it might possibly be confounded with early maturity a'd thus escape notice. The stems are hard and woody and of an unhealthy hute, and the leaves are brown and withered, somewhat of the colour of tobacco. Owing to this the entire plant finally withers and dies before its proper season, thus causing the tabers to be small, only one-half or one-third their usual size.

The plants may be attacked very early in the season when quite young, or they may be nearly full-grown before showing the effects of the disease. The premature decay and death of the leaves prevent the tubers reaching their full size, although their number and size will naturally depend on the time and extent of the attack. As they are unripe and imperfectly developed, they are rather solt and leathery in the skin, and will not keep, and for cooking purposes they are deficient in starch.

When the disease is followed from its earliest stages it is fonnd that the leaves lave dark-brown, well-defined, rather irregular spots, which increase in number and size mintil they overrm the entire leaf and destroy it (Figs. 20,21 ). If the irregular spots are closely examined they are found to be usially marked by concentrie rings, which indicate the stages of growth in the spreading of the spot. Ultimately the leaves become wholly brown on their upper surface, although the under surface may retain more or less of a green tinge, and the brittle, irregularly circular spots often fall out, leaving holes (as in f'ig. 20). The stallis are also of a sickly yellow, instead of a bright, healthy green, and latterly lose their succulenee, beeoming dry.

Although the disease is most noticeable in the leaves which it causes to "curl," it usually attacks the stem close to the ground and gradually reaehes the leaves. 'The stem, as well as the leaves, may thus beeome involved, and the whole plant die down. 


\section{Conditions Favouring the Disease.}

While closely investigating the disease at Leongatha I found that every kind of potato was affected, whether grown in virgin land or not, and irrespective of being grown in any of the three classes of soil found in the districtchocolate, gray loam, or black loam, the latter being situated near the creeks. The average rainfall is about 40 inches, so that there is abundance of moisture, and it was noticeable that the diseased plants produced no fruit, or plums, as they are called. But the humid conditions necessary for the rapid development of the Irish potato blight are not required here, as this disease can thrive in comparatively dry weather, and in what are considered dry districts. It is also very much in evidence upon light, sandy soils. Whatever tends to weaken the growing plant, whether poor "seed" to begin with, or faulty cultivation or lack of sufficient nourishment in the soil, makes it an easier prey to the fungus which sets up the disease.

\section{Fungus Cacsing the Disease.}

If one of the spots is examined under the microseope it is found to be permeated by fungus filaments, which cause the decay of the tissue, and from. these, dark-brown filaments with transverse partitions project and bear the reproductive bodies. The spots are prodnced by the fungus filaments, which spread from a centre and absorb the substance of the leaf, until sooner or later a!l the leaves are affected and finally wither away. When the fungus has used up all the nutritive material available, then it prepares for propagating itself. The filaments which spring from the surface are called conidiophores or conidia-bearers, because they give rise at their free ends to conidia, as the reproductive bodies are termed. Each brown conidium consists of a number of compartments divided lengthwise and rrosswise, and terminates in an elongated, slender, colorless, tapering beak, with cross partitions, the beak being single, double, or treble. (Figs. 23, 24, 25.) The conidium may directly produce on its beak a short conidiophore (Fig. 26), which in turn bears a conidium, and in this way chains of conidia are produced. Or the single terminal bea $\mathrm{k}$ itself may become a conidiophore bearing a conidium (Fig. 27). In addition to this, each of the numerous segments of the conidium may germinate and very soon produce fresh conidia (Figs. 29, 30), so that in a very short period of time innumerable conidia are produced, and there is no danger of the supply falling short. When ripe these conidia readily fall away, and are carried by the slightest breath of wind to fresh leaves, where under the influence of moisture they soon begin to germinate. When a conidium reares a noist spot on a leaf, the various cells composing it put forth delicate filaments which enter the stomata, or breathing pores, and safe inside produce the mass of filaments from which fresh conidiophores soon arise (as shown in Fig. 22). It can easily be understood how the fungus spreads, and on the dewy leaf reproduces itself with amazing rapidity.

Altrnaria is regarded as a "weak parasite," that is to say, it cannot gain a footing and produce much injury unless the vitality of the plant is lowered from some other cause. Then, when once the mycelium has reached the tuber, it will "hibernate," as in the case of Ir ish Blight. Hence ever thing which tends to produce a healthy and vigorous crop, such as well-selected "seed" from a clean district, deep ploughing, nanure where necessary, and thorough tillage, will iicrease the resistant power of the plant and lessen its liability to this disease. 


\section{Hiberiating Mycelium.}

It has been experimentally proved by Massee that the mycelium of the fungus winters in the tubers, although there is no discoloration of the tissues, as in the case of potato blight. The consequence is that the disease may be transmitted from one generation to another by means of this latent mycelium, and the tubers used as "seed" from a diseased plant may show no evident indications of beng affected. This shows how important it is to select the "seed" when the tubers are being dug, so that only the progeny from healthy plants may be used. How often is the best of the crop sent to market and the culls used for "seed."

\section{Host-Plants.}

This fungus not only attarks the potato, but also the tomato, when it is generally known as "Blak Rot." Tris na'ne was given to the disease from the fart that it was first observed on the fruit, where it forms dark-coloured patches, either at the blossom end or stalk end, or even on any part of it where there is a puncture of the skin sufficient to admit the germ-tube of the conidium. But it also occurs on the leaves, where the spots usually begin as minute dots, and as they enlarge form large blotehes with concentric markings, as in the potato. In this stage it is known as "rust," and when later in the season it attacks the stems it is called by tomato growers, "black spot." They are different stages of the same disease, lowever, and in earh case the conidia are poduced in immense numbers a id readily disseminated. That it is the same fungus, although under different nanes, which produces the disease in the potato and the tomato has been shown by Massee, who has repeatedly produced the disease on tomatoes by inoculation with spores produced on a potato-plant, and rime verst. It would be a' additional check on the identity of the fungus to find out if it produced its conidia in chains, as in the potato, and was therefore an Altemaria. On carefully microscopically examining specimens from the tomato, I found conidia attached in chains of two or three (as shown on the potato in Plate VIII.), so that the Macrosporium tomuto of Cooke is really the same fungus as that on the potato. It has also been found here on the Blark Nightshade (Solanum nigrum) As in the potato, the spots on the leaves have concentric rings, and on the stem there are large blotches forming black strips and causing its decay,

\section{TREATMENT.}

It is satisfactory to note that growcrs themselves, as the result of dearbought experience, have arrived at a means of coping with this disease. In seeking to account for it, the only explazation they could offer was that the "seed" had run out, and the evident remedy to get new "seed" from another district. It is not considered safe to plant the same potato "seed" for more than two sessons, and even in the second season there may be a considerable loss, even as much as 20 per cent. I personally examined a number of fields under similar conditions, and found considerable variation. In one field, which produced six tons of good sound tubers the previous season, in the following year the growth was very unsatisfactory, as from their first appearance above ground the tops were weak and sickly, and a number never came up at all. In an adjoining paddock, where the soil was sinilar, and the new seed potatoes planted the same week, and for the first time, the produce was at the rate of 11 tons per acre without misses, and the plants all strong and hea! thy. It is not only necessary to have fresh "seed," but to adopt a rotation as well, and although the growers had no idea as to why these measures were useful in checking the disease, it becomes apparent when the cause of it is considered. 
From the nature and mode of life of the fungus causing the disease, and from the experience of growers, the following recommendations may be made :-

1. Select clean "seed" from a healthy crop grown in a district free from the disease.

2. Do not plant potatoes in succession in the same paddock, as the disease is thereby encouraged and perpetuated. It has been observed that where the disease already existed, it is much worse in the year following if potatoes are planted there.

3. High eultivation and all that it includes will lessen the liability to attack.

4. All tops should be burned that have shown the least traces of infection as the conidia and spawn live through the winter on such refuse.

5. Tomatoes should not follow a diseased crop of potatoes, or the reverse.

6. Spray with Bordeaux mixture or copper-soda solution, as recommended for Irish potato blight. This must be done early, as the grower must anticipate the attack and not wait until he sees the plants succumbing to the disease. In the United States of America, where the disease seems to be worse than in other countries, spraying has been successfully and extensively adopted, and it has been found there that spraying at the rate of 100 gallons per acre gave better results than 50 gallons per acre.

7. Since the mycelium of the fungus winters in the tubers, it will probably be found that heat destroys it, as in the case of Irish Blight.

$$
\text { (Plates VII., VIII.) }
$$




\section{III.-RHIZOCTONIA ROT, OR POTATO COLLAR FUNGUS,}

\section{Iypochnus solani Prill. and Del. = Rhizoctonia solani $($ Kuehn $)=$ Corticium vagum var. solani Burt.)}

On very young potatoes it is quite a common occurrence to see them more or less covered with what looks like little specks of adhering dirt (Fig. 58), and delicate brownish threads spreading between them like a cobweb. On full-grown potatoes, and very often on those sold for "seed," there is the same appearance, but only more pronounced, the specks being a little larger, something like small shot, and the grower tells you, when his attention is called to them, that they are only little particles of manure sticking to the potato. (Plate IX.) When you try to rub them off, however, they still remain, and if you wet such a potato the spots stand out quite black. Tery often they can be scraped off with the finger-nail, as they scarcely penetrate into the skin, and they are generally considered of no particular importance, But, as we shall see immediately, these little specks develop, under suitable conditions, into a fungus, which mav either cause the tubers themselves to rot, or the young potato plants to decay at the "collar" and die right off. (Plate XI.) This fungus is just another illustration of what is so commonly met with in fungus diseases, of the small beginnings which are entirely overlooked and neglected by the so-called practical man, and show "what grest events from little causes spring."

Rhizoctonia, which literally means root-destroyer, is the name given to one stage of this fungus, which is usually confined to the underground parts of plonts. It is found on quite a variety of roots and tubers, and was first discovered by De Candolle in 1815 attacking the roots of lucerne and clover and the corms, or underground stems, of the crocus. As early as 1858 , it was observed by Kuehn on potatoes in Germany, producing what he called the "pock discase" on the tuber, because it appears on the skin of the potato in the form of minute dark-brown pustules. It is now known to be very widely distributed, being found in America, Europe and New Zealand, and for some years past it has been noted by myself in Australia. It is now becoming very prevalent, as it has hitherto been allowed to spread and multiply without any effort being made to check it. In fact it is not regarded as of any consequence by the majority of growers, and seed potatoes with the pustules are freely planted.

In order to warn growers against the dangers of using such seed potatoes, and to enable them to understand the nature and cause of the disease, a full and illustrated account is here given.

\section{Host-Plants and Parts Affected.}

Just as the Irish Blight does not confine itself to the potato, but is found on quite a number of plants, so this disease has been met with on the most varied economic plants, as well as on such ornamental plants as the carnation and violet. It has been recorded on the sugar beet as well as the potato, lucerne and clovers, carrot and celery, cabbage, cauliflower, and radish, lettuce and rhubarb. It may not be the same species of the fungus in every instance, capable of passing from one plant to the other and infecting it, for experiments in cross-inoculation would be necessary to settle that point.

The parts visibly affected vary in different plants. In the potato it may cause rotting of the tubers, so as to give rise to an appearance resembling brown rust, (Plate X.) It may also cause a stem rot just at or below the surface of the soil, also involving the slender roots (Fig. 120), and a disease 
known as "Rosette" (Plate XL.), in which the leaves are all clustered together, owing to the normal growth being checked. In the beet, carrot, radish, and turnip it causes a root-rot; in the cabbage, cauliflower, and celery a decay of the young seedlings; in the lettuce and rhubarb a leaf-rot, and in the lucerne and clovers the roots are attacked, causing the deatl of the parts above ground.

In Australia, so far I have only found rhizoctonia on the potato-plant, and it was first described in Victoria in March, 1903, and on the turnip in May, 1911.

\section{CaUse of THE Disease.}

The fungus causing this disease requires to be studied before the symptoms produced by it can be understood, and the life-history of it, as it occurs on the potato, will be dealt with here. There arc at least three well-marked stages in its history--the resting, the vegetative, and the reproductive-and because the first is the only one which has hitherto forced itself upon the notice of the grower, the importance of the fungus as a whole has been very much underrated.

\section{Sclerotium, or Resting Stage.}

The resting or dormant stage appears usually on the tuber itself, also on the stems and rootlets in the form of numerous brown, rust-coloured patches, which, on account of their minute size, may easily be overlooked or mistaken for something else. On wetting such a potato these patches become quite black, and are then quite conspicuous from the way in which they stand out in contrast to the skin of the potato. (Plate IX.)

They vary in size from that of a pin-head to nearly half-an-inch in diameter, and may be almost round, but are usually irregular in outline, sometimes forming streaks up to one-fifth of an inch in length. The external appearance is thus quite distinct, and when one of these patehes is examined under the microscope it is equally so.

Each patch consists of a dense mass of interwoven fungus filaments or hyphae, and the whole constitutes the mycelium. (Figs. 36, 37.) These fungus threads, which at first are white, but ultimately bccome a deep chestnut brown, are composed of numerous branching joints or segments, each of which is usua!ly different from its neighbour, and the filaments consist of characteristic enlargements, which render them readily distinguishable from the filaments of other fungi. (Fig. 36.) They are short and stout, and excedingly variable in shape. They may be compected together in lines, or form elbow-like projections at the sides, from which other joints arise, and so on, until a dense tangled mass arises, constituting the compact darkcoloured growth seen with the naked eve. If an affected potato is kept moist under a bell jar, this dormant mycelium starts into active growth and produces long, white, straight, regularly-jointed filaments, which ultimately become brown and enable the fungus to spread in the moist earth and thus infect other tubers.

These densely compacted, dark-coloured masses of hyphae, in a resting state on the surface of the potato, are known as sclerotia, or hard bodies, and they serve to carry over the fungus from one season to another, being able from their frrm texture and compactness, to withstand adverse conditions, which might prove fatal to the individual strands composing them. These bodies are not uncommon in various groups of fungi, and they vary in size from grains of powder to that of a cricket ball, or even a child's head, as in the case of native bread, or they may be elongated and cylindrical, as in the well-known instance of ergot of rye. 
In the case of the potato-plant, they may either be returned to the soil when the stem deays, or they may remain firmly attached to the tuber. Wheu such tubers are used for seed, the young sprouts are sometimes attacked by the fungus, and the young and tender plants may become rotten just at or below the surfibe of the ground. (Plate XY.) Experiments with diseased and healthy potatoes show that inferted tubers produce a diseased crop, while clean "soed" in clean soil will produce a clesu crop.

The scherotia are produced on the skiu of the pertato by the brown filaments sprealing over the surface like a fine cobweb. These concentrate at a point and wap theneselves tightly round each of her, so as to form a hard compact body, of scolertium. They are thus formed ou the surface and the tuber is absolutrly sound beneath. In some cases, however, the selerotia are formed in the tissues, and they have been found at least half-an-inch beneath the surface of the skin.

Athough generally formed at the surfare of the tuber, so that they can be seratched off with the finger nail, and leave the skin beneath uninjured, yet they may develop filaments and penetrate inside. If sections of such specimens are made, the fungus filaments are seen beneath the skiu, causing the tissur to become brown and decayed in irregular patches to a greater (or lesis depth.

When the pustules are numerous and generally producing filaments inside the potato. the deray of the flesh of the potato is very general and extends inwards. The result is that there is a zone of decayed tissue beneath the skin which may nltimatsly involve the whole of the potato. I have shown two sections of discasod potatoes, the one being dne to rhizoctonia (Plate X.), and the other to plyytoplithora, or lrish Blight (Plate II.) These sections are of special interest, because both represent the disease known in 'tasmania as " brown rust," and it is seen that similar appearanees may be due to different lungi. Fu fart, Plate $\mathrm{X}$. represents a section of the potato sent to me from. Tastumia at the beginumg of the potato trouble as a typical speeimen of "brown rust," and although, generally speaking, this disease is caused by phytoplithora, yet in this particular instance it was dne to rhizoctonia, and no Irish Blight fungus appeared on the speeimen kept under a bell jar, even although it was critically examined daily up to the thitty-third day. I had an opportunity of examining numerous speeimens of diseased potatoes brought by myself from 'Tasmania, and found rhizoctonia very common, giving rise in many instances to the browning of the tissue beneath the skin, known as " brown rust." This example also proves my eontention that from a naked eye examination of the tuber alone, unless the Irish Bhght fungus is developed on the surface, it is impossible to tell without a microscopic examination whether the internal browning of the tissue is due to rhizoctonia or phytophthora.

I have fomd rhizoctonia assoeiated with phytophthora in some eases, but in others rhizoctonia alone has produced a similar effect on the potato.

In comnexion with selerotia on the stem, not only were there numerous fungus filaments creeping on the surface, but the tissue inside the stem and outside the vessels was permeated by them. Young tubers about a quarter of an inch in diameter attached to diseased stems, even at that early stage showed the selerotia beginning to form. On the shender roots the selerotia were also plentiful. A clear case of the fungus filaments passing from the sclecotia on the tuber nsed as seed to the plant produced, was observed at the Experinent Farm at Cheltenham. The old "set" was found with the selerotia upon it. These germinated and the filaments produeed entered the young shoot, so that when the tubers were forming the filaments passed out to them. The young tubers were found eovered with the brown net-work, 
and the filaments were most plentiful at first towards the stalk end, whence they spread all over.

The course of the fungus is easily traced. The filaments extend along the underground branches, or rhizomes, and when the tubers are being formed latcrally or terminally, they pass on to them, covering them at a very ea:ly age with the spider-web-like brown filaments. Sclerotia may be formed very rapidly by the converging brown filaments, as they have bcen found on young tubers when about the size of peas.

\section{Vegtative Stage.}

When a potato with sclerotia and the brown cobweb-like filaments is kept moist under a boll-jai', in the course of a day or two luxuriant colorless hyphas are developed from all the sclerotia, and also from the spider-web hyphas. The colocless livphae may either penetrate the skin of the potato and produce an internal mycelium, or they may attack the young sprouts when they begin to grow.

When the mycelium attacks the young shoots it produces two kinds of hyphae. One kind reaches the inner tissues, is colorless, and, if luxuriant, produees a wet rot, which results in the death of the young plant. Another kind is dark-colored, and grows on the outside of the young stems and roots, and sometimes forms a felt-like covering which girdles the stem and causes the bark to peel off. When this felted mycelium, which may be detached in sheets from the stem, reaches the surface of the ground, it prepares for the formation of spores. A luxuriant, fragile, mealy, white growth surrounds the stem, but does not penetrate it, and as soon as the spores are matured, it dwindles away and disappears. This is the reproductive stage. It is very evanescent, generally appearing after rain and soon drying up.

\section{IIypochnus, or Reproductive Stage.}

Up till 1903 no form of fructification had been discovered in eonnexion with rhizoctonia, and it was previously considered to be one of the sterile fungi. The sclerotia on the tubers, stems, and roots cnabled the fungus to be perpetuated from one season to another, but no spores were produced. In that year, however, F. M. Rolfs, of the Colorado Experiment Station, found the spores, and from the nature and mode of formation of these reproductive bodies, was able to assign a systematie position to the fungus.

Before this, in 1891, Prillieux and Delacroix, described a fungus found at the eollar of the stem of a growing potato as IIypochnus solani, which was evidently the same. Then a similar fungus was brought under my notice in January, 1910, by Mr. Seymour, potato expert. Specimeus of potato-plants were forwarded to me which had rotted at the "collar," and a profuse development of a white mould appeared just above the surface of the ground. This was found to consist of a net-work of filaments connected by cross branches, and producing short branehes at the extremity, the end cells of which became enlarged and swollen. From these swollen cells slender projeetions arose, varying in number from two to six, and at the end of each the hyaline ovoid spores were formed. (Fig. 43.) This was the spore-bearing form of the fungus, and this layer is very delieate and soon dries up. The spores readily fall away, and probably serve for the rapid multiplication of the fungus in its vegetative eondition. The name of Corticium vagum var. solani Burt. has also been given to this fungus, but the spore-bearing layer is not compact, as in that genus. By whatever name it is known, there is no doubt of its connexion with the filaments of the rhizoctonia stage. It is convenient to speak of the three stages of the fungus as if they were distinct, although 
they all belong to one and the same species. As the reproductive stage is considerert to be the highest form of the fungus, it is recognised as the one which affords the most reliable character for naming, so it is classified as IIypochnes solani.

\section{Eafects of the Fungus.}

The most noticeable effect is the mmerous minute dark-colored patehes on the surfuce of the tuber, but this is not regartert as of any serious consequence. It is seen to be of smpreme importance, however, when it is found that it is through the tubers the fungus is introduced into the young plant, as well as into the soil. The stems of the young potato-plants are often rotted either at the eollar or beneath the soil, and they soon die by what appears to be a solt of wet rot. In som? cases the fungus simply causes the bark to peel of right roand the stem, and this girdling or cincturing of the stem makes the tops more lixuriant, while the tubers are either not formed at all or they are small, owing to the sap from above not returning to nowish them. As a result of this, small green potatoes are sometimes formed on the stem above the point of injury.

Potato-tops are often conspicuous in the field with wilted leaves, which sometimes assume a purplish colonr, and the stems may be swollen at the nodes, or where the leaves arise. I have found this appearance associated with rhizortonia, and in some instances the leaves had likewise the characteristio blotches due to potato blight.

There is also a "rosette" "levelopment of the tops, in which there is excessive branching, and these branches with their terminal leaves are clustered togrether to form a bunch. It is not at all uneommon in some potato crops to find a plant here and there with luxmiant foliage, but the top portion wilted and shrivelled and curled up, so that it stands out quite conspicuous among the normal plants. 'The specimen photographed (Plate XL.) was taken from a field of potatoes in March, 1911, and the peculiar appearance was attributed to the Rutherglen bug and other causes. On examining such a plant below the foliage, the stem is seen to be densaly coated with a white nould, rising from the collar upwards, completely surromding the stem, extending to the branches, and even to the under surface of the leaves. There are usmaliy small potatoes developed in the axils of the leaves above ground accompanying this alonormal development. The white mould was als , found coating these acrial potatoes, ancl in some instances they were affected with the blight, which had probably been produced by the spores falling upon them from the diseased foliage. (Plate Xl.) The tubers underground may be larger or smaller, according to the stage of attack, and the extent of injuly by the fungus.

If the attack is early the young shoots droop and die, and sometimes theie is a loss of one-fourth to one-third of the crop from this cause. But if the sttack is late, the plant profuces the aerial tubers in greater or less abundance, and the underground tubers are few, generally small and wimarketable.

\section{Condthons Favouring the Dismase.}

We have no exact knowledge of the eonditions which favour the devel ppment of the fungus. An excess of moisture in the soil, and the presence of freshly-decaying matter will tend to render it more luxuriant. It is found that the fungus thrives well in a sour soil, and therefore liming will be beneficial, but it does not entirely prevent it. It is suspected that the selerotia may develop on the roots of weeds, so that clean eultivation and everything which promotes good sanitary conditions will render the potatoplants more resistant. 


\section{Distribution.}

This disease of the potato is known in Eurspe and the United States of America as doing considerable damage. It was observed in Germany as early as 1858, and it existed in Iowa in 1890. It has also been known in New Zealand for some years, and Kirk reports it in 1908 as the cause of extensive potato failures in the early part of the season. In Australia it was first discovered in March, 1903, when I found it on some potatoes sant from Castlemaine, Victoria. It is now known in Victoria, New South Wales, Queensland, South Australia, and Tasmania. I have just received (19th June, 1911) specimens of young potato-plants affected with the fungus, from West Australia, so that it occurs in all the States.

\section{Treatment.}

Various experiments were carricd out with the sclerotia, or "black speck scab" as it is called, in order to discover some means of destroying the vitality of the fungus. Heating to 120 degrees Fahr., as for Irish Blight, did not destroy it, nor the ordinary steeping in formalin, but corrosive sublimate was effective.

A potato with numerous sclerotia was steeped in a solution of corrosive

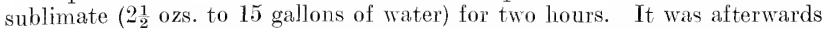
dried, and two sclerotia were removed with a portion of skin, and placed on a glass slide over water. The potato was placed on damp earth in a jar and covered. No sign of germination or growth from the sclerotia or the spiderweb hyphae on the potato appeared after several days.

Formalin was used at the rate of $1 \mathrm{lb}$. to 40 gallons of water in an exactly similar manner, and next day there was luxuriant growth both from the sclerotia on the slide and the hyphae on the potato.

A potato with sclerotia was used as a check and placed on damp eartlı in a jar. In two days there was luxuriant growth from all the sclerotia and from the hyphas on the surface of the skin.

A field test was also conducted at Burnley Horticultural Gardens, where 28 rows of potatoes were planted badly affected with sclerotia, and they were treated in various ways as shown in table V. Corrosive sublimate was again the most successful, only one per cent. being affected in some instances.

But the simplest and most effective method is to use clean "seed," and this is not a difficult matter since the sclerotia are so conspicuous on the skin of the potato. Clean "seed" in clean soil will produce a clean crop.

Not only is it necessary to use clean "seed," but the fungus may be in the soil from a previous crop, and so potatoes must not be planted in the same ground year after year. This rotation of crops is absolntely necessary for healthy growth, and it is the constant planting of diseased "seed" in the same soil that has made rhizoctonia so common that it is difficult to get "seed" of some varieties free from it.

Whenever a parasitic fungus occurs in the soil, particularly in the form of sclerotia, it is no easy matter to deal with on a large scale. Salmon, however, has found that by applying phenol, or carbolic acid, the sclerotia present in the soil are rendered harmless. He used $1 \mathrm{oz}$. to 1 gallon of water, and the plants grown in the treated soil were not only free from disease, but apparently stimulated in their growth.

All seed potatoes showing the slightest trace of rhizoctonia should be rigorously rejected and rotation of crops practised.

(Plates IX., X., XI., XII., XIII., XVIII., XIX., XXXIX., XL., XLI., XLII., XLIII.) 


\section{IV.-POTATO SCAB.}

The term "scab" is applied to quite a number of different kinds of skin trouble, which are due to as many different causes, and since these cannot be determined at a glance, there is a certain convenience in the use of a general term. But when experiments are being conducted for the prevention of scab, it is absolutely necessary to determine the agents at work, and it is want of attention to this which has caused so much confusion as to the effect of different treatments.

Since the study of the diseases of the potato is undertaken with a view to their ultimate treatment, it is necessary to understend clearly the canse and nature of the disease investigated, a ad also not to be misled by a common name applied erroneonsly to the disease. In the whole range of plant diseases, there is none to which this remark is more applicable than to scab, and to illustrate this point, the various forms so-called will be briefly dealt with, in addition to a detailed consideration of those commonly met with here.

The mere mention of the names of the varieties of "scab" will show what a difficult and thorny subject it is, and the so-called forms of it will indicate how superficial appearances are often deceptive. The causes assigned are equally variable.

A mechanical irritation of the skin may result in an excessive formation of cork and thus produce what is known as "scab." Bacteria and fungi are likewise concerned in it, and "wire-worms" and "cut-worms" may gnaw away the skin in patches. Even the blisters or galls produced by the "eelworm." may assume a scabby appearance, and from the point of view of the grower, it is one of the commonest forms of this disease. Amid all this confusion and uncertainty the grower wishes to know how to produce a crop "free from scab," and that is the question which we will now attempt to answer, as far as our present knowledge goes.

\section{The Healthy Skin of the Potato.}

The skin of the potato is really of the nature of cork, and although it is only a thin layer, it is just as distinct as in the cork oak. When a cross-section is made of a small portion of the skin and magnified under the microscope, it is seen to consist of cork cells. These cells are flattened and arranged in rows one above the other, tier upon tier (as shown in Fig. 44k). Immediately beneath these are the cells containing starch grains (st.).

If the skin of the potato formed an enclosed layer all round, there would be no means provided for the admission of air; but just as in the leaves there are little openings or mouths for the admission of air and other gases, so in the skin of the potato there are little raised openings, or breathing pores. These openings are known as lonticels, and at $a$ one is just baginning to be former. The calls at this spot take in moisture, swell, and cause the skin to burst as at $f$, and the lenticels thus formed are filled with loose, whitish, mealy cells. After a long spell of wet weather these white, mealy cells may grow out and appear at the surface, where they might be mistaken for a mould. (Fig. 150.) Under these conditions the cells at f multiply excessively, being pushed up from below, and the outermost cells are thrown off in the form of loose, fluffy material.

The filaments of fungi can enter through the lenticels, and the irritation thus set up may give rise to further growth and the ultimate formation of a "scab." So that even the natural and necessary openings in the skin of the potato may be used for a very different purpose to that originally intended. 
As the result of experiments it has been found that the thickness of the skin varies with the amount of moisture, a dry season producing a thinner skin than a season with adequate rainfall, as well as with the kind of manure used.

\section{True "Scab."}

A true "scab" approaches most nearly to what takes place in animals when a wound is left open and healing takes place under a scab. So in the potato, when a crack is formed or irritation is set up by something corrosive in the soil, or even the pressure of the hard soil against the growing potato, the plant seeks to repair the injury by pioducing a scab composed of corky cells, just like theskin, only the walls are thickened. Even the tissue of the lenticels, under the influence of excessive moisture, may grow luxuriantly, and the outermost cells are cut off by a corky layer aid die. Then the living cells beneath may burst through these dead cells, and cork is again formed with a like result. Rough corky warts or excrescences may thus arise and constitute a scab. In a scab of this nature it is evident we have little power of control; but if the "scaby" apperrance is due to some organism which can be destroyed by chemical or other means, then treatment of the seed potatoes is to be recommended. In the gieat majority of cases known in Australia, the so-called "scab" is the result of an eel-worm, and in a less degree to the fungus known as rhizoctonia.

\section{Experiments to Test the Conditions Favorable to the Production of "Scab."}

It is commonly stated, without any reservation, that if potatoes are planted where there is plenty of wood ashes or abundance of lime, you are sure to get "scab." Then this statement is sometimes qualified to the effect that this is most likely to occur in stiff soils.

So to answer the question, as far as one season could do it, I planted potatoes at Burnley in loose sandy soil, as well as in stiff clay soil. The seed was obtained from one of our most reputable seedsmen, and selected by Mr. Soymour, potato expert. Beauty of Hebron and Coronation were the varieties chosen. At the Burnley Gardens, through the courtesy of the principal, Mr. E. E. Pescott, I was fortunate in securing the right kind of soil. In the lower orchard there was a patch between the fruit trees of loose sandy soil, and in the upper orchard the soil was stiff and clayey. The loose soil in the lower orchard had been used the previous season for an experimental plot of field peas and various clovers, so that it was an excellent rotation for the potato. The plants were cut level with the ground and removed for weighing, and only the roots were ploughed in. In the clay soil strawberries were planted last year and regularly cultivated, but owing to the lack of moisture they were a failure.

The seed potatoes were planted without manure so as not to interfere with the result, and it was observed that although carefully selected, many of the tubers had the little black bodies on the skin, which show up so clearly when wetted, and are the resting stage of a fungus, known as rhizoctonia, or root-destroyer.

Esch plot consisted of a single row, in which 50 potatoes were planted, and the corresponding plots of the two varieties were in the same line. The rows were $3 \mathrm{ft}$. apart, and the potatoes in each row were planted $1 \mathrm{ft}$. apart. The planting wes rather late, taking place on 18th and 20th December, 1909 , and the potatoes were all dug on 19th May, 1910. 
The accompanying photograph (Plate XX.) of the plots in the loose soil was taken on 6th April, showing the luxuriant growth, and the following table gives all the necessary details :-

TABLE V.-Test of Conmtions Favorable or Unfavorable to the Production of "SCAB."

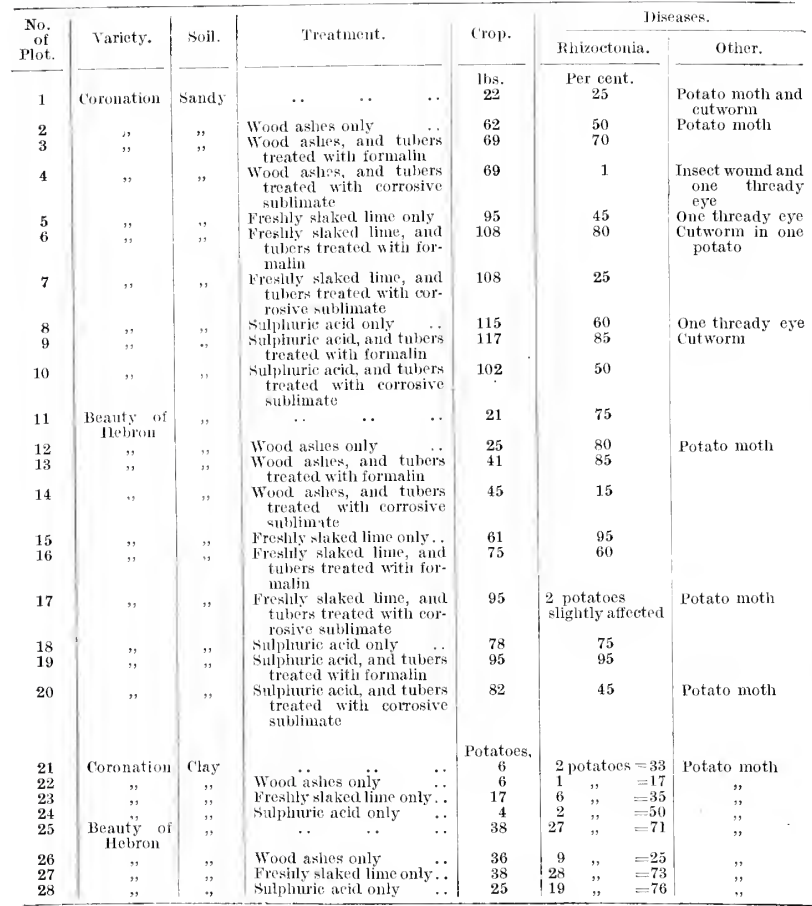

The yield of potatoes, it will be observed, was very uneven, and in the clayey soil the crop was a comparative failure. In the loose soil plots 1 and 11 gave the smallest yields, beeause they were planted elose to the fruit trees, and not only was their nourishment affeeted by the roots of the trees, but being in the shade the plants eould not manufaeture the necessary stareh to store away in the tubers.

In the clayey soil the season was so dry that little growth took place, and the result shows elearly how the same varieties planted at the same time, and undersimilar weather eonditions, may yield so differently owing to the eharaeter of the soil and its eapacity for absorbing moisture. The yields were so small that the number of potatoes in eaeh plot is given. In the upper portion, where Beauty of Hebron was planted, the soil was looser and the yields eorrespondingly larger. 
But the object of the experiment was not to test the yield of varieties, only to find out the conditions favourable to the production of "scab," and it may be stated at once that $n 0$ true " scab" was found in a single potato. Various wounds and scars due to insects were found, such as the eut-worm and grub of the potato moth, and in isolated cases the rhizoctonia produced scars which might be called "scab" ; but there was none of that superficial, rough, patchy, or continuous elevation of the skin which is generally regarded as such.

Lime freshly slaked and wood ashes were freely used in the rows, as well as acid, applied by watering the ground just before planting with a solution of one teaspoonful of commercial sulphuric acid in a gallon of water. The saed potatoes were likewise steeped in formalin and corrosive sublimate solution, as recommended for the prevention of "scab," and then planted with acid, lime and wood ashes, but without the production of "scab."

The results of this season's experiments show that "scab" is not always produced even in alkaline or acid soil, and that there are other factors controlling its development, such as variety, date of planting, and nature of soil, \&c.

The season was practically dry, as the rainfall from the time of planting to that of digging shows:-

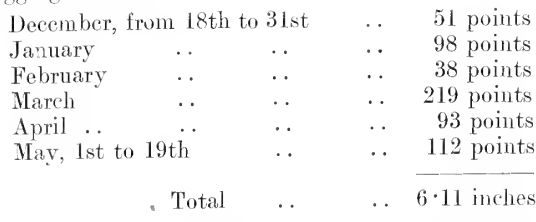

The sclerotial form of rhizoctonia occurred in every plot, more or less, as might have been anticipated from its general occurrence on the seed potatoes used.

\section{SO-CALlED "SCAB."}

During the last two seasons every form of skin disease affecting the potato in this and some of the neighbouring States has been brought under my notice, with the result that more definite knowledge has been gained as to the causes producing them. I have also personally visited a number of potato-growing districts, and in some of them have inspected every potatofield, so that the disease was observed at different stages. It is not possible in every case to account for the appearances presented, and they are not necessarily due to organisms of any kind; but, speaking generally, they were found to group themselves under the following heads:-

1. Mechanical causes.-There were certain blemishes on the skin which were not associated with any evident organism, and may have been due to unsuitable conditions of soil and climate. Thus, when the season is dry and the soil comparatively stiff, the pressure of the growing tuber against the unyielding soil may cause injury. The injured tubers contimue to grow, and as the original blemishes expand and become larger and larger, they arc surrounded or covered by a thickened layer of wound cork, constituting a "scab." The injury may be slight when it produces merely a corrosion of the skin, or it may extend deeper, according as the adverse conditions affected the tuber early or late in its growth (Fig. 63). 
2. Wire-worms.- The wire-worm, which is the grub of the click beetle (Lacon sp. and others), is very prevalent in light soils and land newly broken up. It gnaws away a'd perforates the skin of the potato. causing scars or blemishes, which have a "scabby" appearance, In mary insta res they were antuslly found on these scars, and on exanining the soil in which such potatoes were grown, they occured in great abundance. This pest does considerable damage to the crop, as it is very voracious and may attack every poteto.

3. False Hire-worms or Millipedes.-These are often eonfounded with the true wire-worm, although they are quite distinct, and from the large number of feet they possess, they are popularly called "thousand feet." They are closely allied to insects, and different sprcies of Julus disfigure the potato (as shown in Fig. 65). They were not met with so frequently as the former.

4. Cut-xorms.-In somo instances there were abrasions of the skin found associated with the cut-worm, and the soil in which the tubers grew rontained them in abundance. T'hey a!so eat into the potato and produce unsightly scars. I am indebted to Mr. C. Frenc?, jun., for the names of the following genera of cut-worms which attack the potato:-Agrotis, Leucania, IIeliothis, and Mamostra (climbing cut-worm).

5. Potato Moth.-This moth (Lita solanella) is very common in some seasons, and the grub produces the well-known tunnel"ing of the potato; but in some eases there were black, warty excrescences at the "eyes," which were traced to this moth (Fig. 57).

6. Potato Eel-uorm.-In its typical form it produces blisters or galls, which can only form when the potato is growing, and is readily recognised; but the blisters may be broken and form rough patches, or the eel-worm may affect the tuber at different stages of its growth, so that all sorts of abrasions and excrescences result. In all the leading districts where potatoes are grown the eel-worm has been found, and I have no hesitation in saying that it is the main cause of the so-called "scab." Hence, from the point of view of the practieal grower, as well as that of the plant pathologist, it is that form of skin disease which eauses the greatest amual foss, and the discovery of measures of prevention will be of inmense benefit to the potato industry. While the eel-worm is so generally distributed, there is one notable exception as to the kind of soil in which it oceurs. In the dried-up swamps consisting of peaty soils, such as are found in the Portland, Tynong, and other districts, and which will readily buri when a hight is applied to them, I have never come across a "blistered" potato. But in the dark sandy soils surrounding and adjoining these dried-up swamps a little higher up, sueh potatoes are quite common. There is something in a peaty soil whieh is uncongenial to the eel-worm, and it suggested to me that it would be a very useful experiment to test the effect on the eel-worm of applying a dressing of sueh soils to the onion-growing land of Portarlington and elsewhere. At any rate, the potato eel-worm does not thrive in soils of a peaty nature. 
7. Scab and Oospora scabies.-On the surface of "scabby" potatoes, when freshly dug, I have often found a delicate grevish mould which is very evanescent. It soon dries up and disappears on exposure to the air, and in order to get specimens for microscopic examination, it is necessary to convey the diseased tubers embedded in the soil. When a small portion of this delicate grey mould is examined under the microscope, it is found to consist of very slender lyaline filaments, generally curved in various ways, branching slightly, and sometimes apparently septate. The aerial hyphae quite agree with the description of "breaking up into bacteria-like segments, after producing spirillum-like 'spores" by the coiling of their free extremities " (Fig. 127).

The description fits exactly that of Oospora scabies, but I cannot accept this fungus as being the main cause of the scabby appearance, since these tubers were found swarming with "eel-worm," which were invariably present, even in the early stages of the scab. Thaxter has shown that a form of scab may be produced by the fungus (Fig. 64), but in Victoria, at least, the symptoms are so pronounced, and the breaking of the "blister" is so evident, that we cannot dismiss the eel-worm as a mere secondary cause. It is not unusual in "scabby" potatoes to find the "blister" merging into the "scab," and when potatoes with blister were planted and produced only scabby tubers, the comnexion between the two is all but proved. This fungus was also found associated with rhizoctonia seab (Plate XLIII.), so that it has never been found here as an independent fungus causing "scab."

It may also be noted that I have found "blister" and "blight " together in the same potato, so that the presence of the one does not exclude the other.

I have found Oospora scabies common enough on potatoes, but not under conditions to suggest that it was always the primary cause of the "scab." It occurs on a roughened skin as well as on broken blisters produced by eelworm, and since these also occur without Oospora being present, it camnot be considered the cause under these circumstances.

There are several very destructive fungi in other countries associated with "scab," but fortunately they have not yet been introduced here. Bacteria have also been found, but their connexion with the "scab" has not been definitely settled. In the United States, in 1890, Bolley found bacteria associated with the "scabby" tissue on the skin of the potato, and he successfully carried out infection experiments with a specific bacterium which was isolated. The diseases caused by insects or millipedes are dealt with by my colleague, Mr. French, so that no further reference is made to them here.

\section{"SCAB" in AUstralia.}

For a number of years growers have recognised a skin disease which disfigured the potatoes, and was generally known as "scab." Inspectors under the Vegetation Diseases Act likewise condemned them as such, and naturally there was a desire for information as to the nature of this disease in order to prevent it if possible. It was generally attributed to a fungus, which is 
a common cause of "scab" in America, and known as Oospora scabies; but the fungus has only been found here on bioken blisters, and cannot be regarded as a primary cause. In the great majority of eases such potatoes showed the presence of the eal-worm, and the "scaby" appes:ance was mainly due to this cause.

\section{Potato Blister and "Scab."}

The disease caused by the eel-worm on the surface of the potato is generally known as "blister," because the eel-worms cause little galls or swellings to be formed on the surface (as in Fig. 45). But the appearanee presented by these gal's vary considerably, according to the stage of growth at which the potato has beeil attacked. These swellings may sometimes oceur just as the potatoes are forming, and when growth has advanced, the blisters or galls have husit and form rough patches, which may run together and over considerable portions of the potato. Or the tubers may have reached nearly their full size, and then these broken b]ister's are so numerous and so confluent that the greater portion of the surface is one eontinuous irregular mass of scab-like excrescences. The appearance of "scab" is even more pronounced when the patches are more or less isolated, and roughened, raised, rounded, or irregular.

There are stages, too, in the potato when no eel-worms are to be seen, and although the surface may give no indications, when the tubers are eut across or lengthwise, there are innumerable little poekets of eggs beneath the skin, just waiting for favourable eonditions when the tubers are planted to develop. Such sections are shown in Fig. 55, and some idea may be gained of their numbers when a full-sized potato is seen to have these egg-poekets erowded together beneath the entire surface of the skin.

An expert has been appointed by the Department of Agriculture to investigate the diseases caused by eel-worms, and no doubt he will throw light upon the different effects produced on the potato at different stages of its growth, from a study of the habits of the eel-worm itself. It is, therefore, no part of the duty of this branch to deal with that phase of the subjeet; but as "scab" was known to be caused by fungi, and sinee it was supposed that the prevailing forms were due to them, I was indueed to investigate the matter from the point of view of finding a remedy before this appointment was made.

\section{TREATMENT FOR "SCAB,"}

Experiments were carried out at Bunyip in season 1907-8, with the whiteskimned variety Carman No. 1. "Scabby" potatoes, the same as shown in Fig. 5l were used for "seed" and planted in clean land, in plots eonsisting of $1 / 100$ ths of an acre. The "seabby seed "was treated respretively with a solution of corrosive sublimate or mereuric chloride, and formalin, and it was also sown with dry bluestone powder. Corrosive sublimate was used at the rate of $1 \mathrm{oz}$. in 6 gallons of water, and Sehering's or CumingSimith's formalin at the rate of $1 \mathrm{lb}$. in 30 gallons of water. The corrosive sublimate was first dissolved in a few quarts of hot water and then made up to the proper strength, using a eask or wooden vessel, as the solution corrodes metal. 
The seed potatoes placed in a loose bag were steeped in the solution for two hours, then cut and planted after being allowed to dry. In addition to the "scabby ssed," clean "seed" was taken and artifically infected with scab by shaking up and rubbing the two sorts together.

The following were the results:-

Table VI.--Results of Treatuent of Scabby "Seed."

\begin{tabular}{|c|c|c|c|c|c|c|c|}
\hline \multirow[b]{2}{*}{ Plot. } & \multirow[b]{2}{*}{ Ireatment. } & \multicolumn{2}{|c|}{ Clean Potatoes. } & \multirow{2}{*}{$\begin{array}{c}\text { Scabbed. } \\
\text { Lbs. }\end{array}$} & \multicolumn{2}{|c|}{ Total Yisld. } & \multirow{2}{*}{$\begin{array}{l}\text { Percentage } \\
\text { scabbed. }\end{array}$} \\
\hline & & Lbs. & $\begin{array}{c}\text { Rate } \\
\text { per } \\
\text { Acre. }\end{array}$ & & Lbs. & $\begin{array}{l}\text { Rate } \\
\text { per } \\
\text { Acre. }\end{array}$ & \\
\hline 1 & Scabby seed, untreated $\quad \ldots$ & 58 & $\begin{array}{l}\text { Tons. } \\
2 \cdot 11\end{array}$ & 77 & 135 & $\begin{array}{l}\text { Tons. } \\
6 \cdot 0\end{array}$ & 57 \\
\hline 2 & $\begin{array}{l}\text { Scabby seed dipped in corrosive } \\
\text { sublimate solution }\end{array}$ & 195 & $8 \cdot 14$ & 2 & 197 & $8 \cdot 16$ & 1 \\
\hline 3 & $\begin{array}{l}\text { Clean smooth seed artificially } \\
\text { infected with seab }\end{array}$ & 89 & $3 \cdot 19$ & 84 & 173 & $7 \cdot 1 \frac{1}{4}$ & 48 \\
\hline 4 & $\begin{array}{l}\text { Scabby seed dipped in formalin } \\
\text { solution }\end{array}$ & 194 & $8 \cdot 13$ & 30 & 224 & $10 \cdot 0$ & 13 \\
\hline 5 & $\begin{array}{l}\text { Scabby seed sown with dry } \\
\text { bluestone powder }\end{array}$ & $8 I$ & $3 \cdot 12$ & 70 & $15 \mathrm{l}$ & $6 \cdot 1.5$ & 46 \\
\hline
\end{tabular}

The "scabby seed" planted without treatment yielded 75 per cent. diseased, and even when smooth, clean "seed" was artifically infected there was 48 per cent. of scab, while the "scabby seed" treated with corrosive sublimate was practically elean, only 1 per cent. being affected very slightly. The results were not quite so good with formalin, as 13 per cent. were diseased.

"Scabby seed" planted in a clean soil produced the same, and there is no doubt about the efficacy of the treatment for "scab" when the treated potatoes are planted in land free from "scab." But the question naturally arose what would happen if the treated "scabby seed" were planted in ground subject to eel-worm, and it was to answer this question that the following experimental plots were planted. It was my intention to duplicate the experiments in clean and "scabby" ground, but no clean ground was available. The plot chosen was fully a quarter of an acre, in a long strip, so that each experimental row shared equally the variations in the character of the soil. It consisted of grass land in 1907 when it was broken up, and when planted with potatoes in 1908 , the crop was very bad with blister and "scab." In 1909 , it was again planted with potatoes, and was practically free from blister and "scab," having only odd potatoes affected.

After the crop was harvested in 1910, a crop of oats was sown and ploughed in when about three feet high. The ground was in excellent condition at the planting season, and about a month before had been manured at the rate of 3 cwt. per acre of bone dust and superphosphate sown broadeast and harrowed in.

For the purposes of the experiment Carman No. 1 was selected, and "scabby seed" of the same variety grown on the farm was used. The same variety was planted and experimented with in 1907, so that the results were quite comparable, the one being planted in clean ground, and the other in ground that had produced scab.

The planting was carried out, and the "seed" cut exactly the same as in the general crop, on 23rd September, 1910. 
The crop was inspected on 19th Dacember, and the various rows were all well forward and looking very healthy, as shown in the photograph. (Plate XLIV.)

There were ten separate rows, and the digging took plase on 13th February, with the following results :-

Table VII.-Comparative Rlasults of Treatuent of Clean and "Scabiby" Seed Planted ox "ScabbY" holl.

\begin{tabular}{|c|c|c|c|c|c|c|}
\hline plot. & $\begin{array}{l}\text { Natur: of } \\
\text { Seefi. }\end{array}$ & Treatment. & $\begin{array}{l}\text { Total } \\
\text { Yicld. }\end{array}$ & Smalls. & scabby. & $\begin{array}{l}\text { Per Cent. } \\
\text { Scab. }\end{array}$ \\
\hline 1 & ('lenn & $\begin{array}{l}\text { Steeped in lime-water Borleaux for } \\
\text { thour }\end{array}$ & $\begin{array}{l}1 \mathrm{bs} \\
307\end{array}$ & $\begin{array}{l}\text { ltis. } \\
41\end{array}$ & $\begin{array}{l}\text { lbs. } \\
23\end{array}$ & $7 \cdot 5$ \\
\hline 2 & Seobby .. & "t $\quad, \quad, \quad, \quad, \quad, \quad$, & 332 & 36 & 91 & $27 \cdot 4$ \\
\hline 3 & cheon. & $\begin{array}{l}\text { Steeped in formalin }(1 \text { in } 40 \text { ) for } 2 \\
\text { ho: } 2 \text { rs }\end{array}$ & 263 & 47 & 10 & $3 \cdot 8$ \\
\hline 4 & Seabby & , $\quad, \quad, \quad, \quad$, & 372 & 40 & 45 & $12 \cdot 1$ \\
\hline 5 & $(1,2 m \quad \cdots$ & (heck-no treatment $\quad$.. & 315 & 36 & 13 & $4 \cdot 1$ \\
\hline 6 & Sctbby ... & 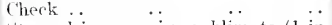 & $26+$ & 21 & 140 & $53 \cdot 0$ \\
\hline 7 & Scabby . & $\begin{array}{l}\text { teeped in corrosive sublim ite ( } 1 \text { in } \\
1,000 \text { ) for } 2 \text { hours }\end{array}$ & 363 & 31 & 22 & $6 \cdot 1$ \\
\hline Q & ('lean .. & & 324 & 45 & 11 & $3 \cdot 4$ \\
\hline & siabby. & $\begin{array}{l}\text { Steeped in bluestone solution (2 per } \\
\text { cent.) for 1-hour }\end{array}$ & 297 & 36 & 38 & $12 \cdot 8$ \\
\hline 10 & ('lean $\cdots$ & $\begin{array}{llll}, & , & , & ,\end{array}$ & 244 & 32 & 17 & $7 \cdot 0$ \\
\hline
\end{tabular}

These experiments with "scabby" potatoes, in which the scab was due to eel-worm, and the "seed" planted in soil subject to the disease, show-

1. Thet "scabby seed" invariably produces scab in the crop, in some cases amounting to 53 per cent. when the "seed" is untreated.

2. That clean "seed" is always liable to become infected.

3. That treatment of clean "seed" does not protect it from infection.

4. That treatment of "scabby seed" reduces the amount of scab considerably. While the mntreated scabby seed produced 53 per cent. of scab, when treated with corrosive sublimate or formalin, it never rose above 12 per cent.

5. That corrosive sublimate is the most effective protection against scab. (Plate XIV.)

6. That the yield from "scabby seed" was invariably increased when treated.

Experiments were also carried out at Buraley Horticultural Gardens with clean and "scabby" Carmons, the same as that used in the experiments at Bunyip. There ware twelve short rows altogether with twenty sets planted in each, and a distinction was made between the "seed" in which the blisters were unbroken and that in which they were broken, forming the so-called scab. The ground had been under wheat the previous year, and the planting took place on 4th October, or eleven days after that of Bunyip. 
The potatoes were dug on 24th January, when the tops had naturally withered, with the following result:-

Table VIII.-Comparative Results of 'Treatuent of Clean and "Scabby Seed" planted in Clean Ground.

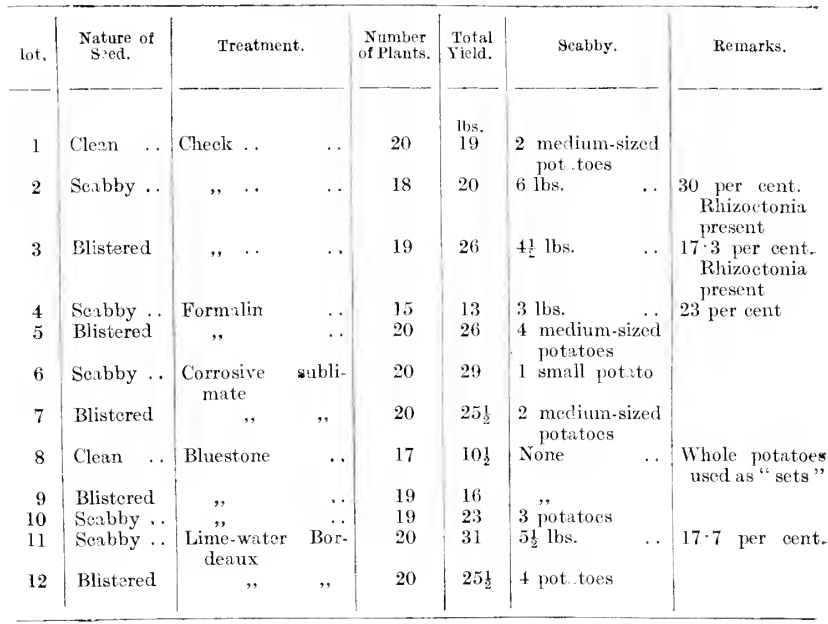

The yields were variable, and some portions of the ground were very wet during the growing season, so that in such a small area it would be misleading to draw conclusions as to the effect of the different treatments on the relative yield. But as regards the scab, while bluestone was effective, the corrosive sublimate treatment was most satisfactory on the whole. None of the bluestone "seed" produced a blistered crop, but where diseased it was of the nature of scab or broken blister.

If the results are compared when "scabby" potatoes are planted in clean ground, as at Burnley, and on land subject to scab, as at Bunyip, it is found, in a general way, that the clean ground yjelds practically a clean crop, when the "seed" is free from scab to begin with, and when "scabby seed " is used, under the same conditions, there may be from 30 per cent. or more of "scab" produced. But if the ground is subject to scab, then even clean "seed" will yield a scabby crop, although it may not be very bad, and the "scabby seed" may produce a crop intensely "scabby." When steeps are used, such as corrosive sublimate or formalin, then in clean ground there does not seem to be any advantage when clean "seed" is used, but when "scabby" the corrosive sublimate renders the produce practically free.

\section{Black Speck, or Sclerotial Scab.}

This "Black Speck Scab," as it is sometimes called by growers, is very common on potatoes, although it is generally regarded as of little or no importance, because in one stage of its existence it can easily be scraped off, and the skin beneath it is found to be intact. This is only the resting stage of a fungus, however, which is the cause of a potato-rot, and has already been 
treated at length under that heading, but it is mentioned here because it may also give rise to one of the numerous forms to which the term "scab" is epplied.

It is well known in other potato-growing countries, particularly Ireland, where it seems to be very prevalent, judging by the following statement:"Perhaps the commonest form of potato-scab in Ireland, and the cause of a potato-rot, too, is that due to the fungus Rhizoctonia solani, characterized by the presence of sclerotia / the black specks] on the tuber, and sometimes on the haulnu."

In Germany, it would appear that this disease is not considered to be very injurious, since it is not supposed to affect the underlying skin, but that view is founded on a misconception.

The resting-stage, or sclerotium, is confined to the surface of the potato, since it is formed by the converging strands of fungus filaments overspreading the surface like a delicate spider's web. These come together at various points, and roll themselves up into hard masses, which become black. They are in this condition able to withstand the variations of the weather and other injurious influences, and remain attached to the potato until it is again planted and sends out frosh shoots. But there is another stage of the fungus, in which black masses arise at the surface, not from superficial strands, but from deep-seated fungus filaments, or spawn (as shown in Fig. 37). These black "scabs" not only disfigure the surface, but their roots, embedded in the "flesh" of the potato, may, under suitable conditions, produce a brown rot (Fig. 37)

The black scab-like patches stand out clearly when wetted, and the most superficial observer cannot fail to notice them as danger-signals.

The most evident means of escaping this disease is to rigidly reject any tubers showing the slightest black speck before planting, and the further precaution of steeping in corrosive sublimate may also be taken.

\section{Rhizoctonia Scab.}

In treating of Rhizoctonia rot, it was pointed out that the fungus causing it passed through three different stages in its life, each of which is so unlike the other, that at first sight they seem to be quite distinct organisms. One stage-the sclerotium, or resting-stage-forms what is known as "Black Speck Scab" on the surface of the potato, and, because it looks so harmless, geowers have hitherto been in the liabit of treating it with something like contempt. But under suitable conditions of soil and climate, of heat and moisture, these insignificant-looking black specks can produce immumerable fungus-filaments, which may either penetrate the potato, and produce a " rot," or spread all over the surface, and give rise to an unsightly brown scabby mass (Plate XLII.). If such a potato as that shown in the Figure is examined, very little of the normal smooth skin is left, and it is seen to be covered by very delicate, brown, spider-web-like threads. Alongside of these clean patches the surface is raised and broken up, and thrown into folds and puckers, so that you can rub your fingers over it, and a scurf comes off like cork dust. If you examine the base of these "scabs" with a microscope, you will find that the delicate filaments have irritated the skin, and, in conconsequence of this irritation, have produced the corky layers or "scabs" which, although superficial, reduce the marketable value of the potatoes. Not only does this fungus occur on the surface of the tuber, but the small portion of the stalk, or rhizome, adhering to it is practically one mass of the 
filaments, and this shows how the fungus may have reached the tubers from the parent-plant. But the "seed" potatoes may even have been clean, and yet the plant may have become infected, for in the scil, which happened to be a peaty loam, there was abundance of the fungus-filaments disseminated through it. No eel-worm nor insects of any kind were found associated with the disease after a thorough examination of the tubers, and the soil as well. There can be no reasonable doubt that the fungus is the cause of the inischief, and clean potatoes, in thoroughly infected soil, have been planted as a test.

Treatment will be the same as that recommended for Rhizoctonia rot, but steeping the "seed" potatoes in corrosive sublimate might be tried to test how far it would be effective in reducing the "scab."

\section{II. "SCAB" in OTHER COUntries.}

There are numerous varieties of so-called "scab" found in other countries, which, fortunately, have not yet raached Australia, because the organisms causing them have not been introduced, but there are others common whereever potatoes are grown.

A short account of the principal forms due to fungi is here given, with illustrations, to show how varied is their origin, and at the same time to point out their characteristies.

\section{American or Oospora Scab (Osspra scabies, Thaxt.).}

This is the form commonly met with in Amsrica, and is due to a minute parasitic fungus. It may appear on the young tuber, or sometimes, when it has reached a considerable size, in the form of minute raddish or brownish spots. The discolouration usually begins at the lenticels, whence it may spread quite rapidly to adjoining parts. The colour deepens, and an abnormal development of cork occurs in the affected parts, often covering a considerable area. If forms an irregular scab-like crust on the surface, or more frequently the surface is deeply cracked and fuirowed. The appearance, as in most skin-diseases, depends largely ou the period of attack. If the tubers are infected when very young, then the injury is most severe, as the young scabs soon split and expand with increasing growth, while, if attacked later, when the skin is tougher, there is more resistance offered to the parasite. The delicate mould on the young scabs was first discovered and named as above by Thaxter, in 1890. This disease is controlled by steeping the seed potatoes either in formalin or corrosive sublimate, but this should be combined with a judicious rotation of crops (Fig. 64). The above description of American "scab" is essentially that given by Thaxter, but the fungus alone is never found producing these effects in Australia. It is singular, to say the least of it, that in the most recent American works on Plant Diseases there is only one potato "scab" montioned, and it is taken for granted that it is the same "scab" which occurs all over the world. It is beginning to be suspected, however, that the fungus Oospora scabies, determined by Thaxter in 1890, is not the universal cause of "scab" it was Iong supposed to be. Thus Duggan, in his "Fungus Diseases of Plants," says - "It is not positively" demonstrated, however, that all of the surface injuries known as "scab" are properly referable to this fungus;" and Stevens and Hall, in their "Diseases of Econonic Plants," state- "There is some evidence that there is more than one form of disease which passes under this name in Europe." With us this fungus is not of much economic importance. 
2. "Corky," Powdery, or Spongospora Seab (Spangospora subterran"a (Wallr.) Jolnson = Sorosporium scabies (Ber's.) F. v. W.)

The "scabby" spots are very conspicuous from the damage they caise to the potato. They are at first raised above the general surface of the tuber, and form patches one-eighth to one-quarter inch in diameter. The raised surface becomes ruptured, and the spore-balls of the fungus are seen inside like so many loose grains. The elevation becomes a depression, as the sporeballs fall away, and sometimes these excavations are an inch deep. The parasitic fungus literelly gavis away the surface of the tuber, which, in some cases, resists the parasite by forming a protecting layer of cork, but usually the powdery sunf-coloured spore-balls ara the most prominent feature, hence the name of "Powdery Potato-scab)" sometimes given to the disease (Fig. 66). The disease was observed in Norway in 1886, and is now finown in Germany and Britain, particularly in the west of Ireland. Planting "scabby" tubers propagates the disease, as well as planting healthy tubers in "scabby" soil.

Since the fungus producing this disoase is of the same class as that causing the club root or botch in cabbages, turaips, \&c., it has been suggested that lime, which is so beneficial in the latter case, might also serve to prevent the other. But, on experiments being tried, it was found that lime, instead of being injurious to the fungus, was actually favorable to it. Steeping the seed potatoes in formalin, and planting in clean ground, had a beneficial effect.

This fungus has only been found on the potato, and may, therefore, be starved out by an alteriation of crops.

\section{3. "Black Scab" or " Wart Disease" (Synchytrium endobioticum (Schilb.) Percival $=$ (hrysophlyctis cndobiotica, Schilb.)}

This disease was first noted in 1896 in Hungary, and since then it has been fonnd widely distribnted in Europe (including Great Britain and Ireland), and quite recently in Newfoundland. Although comparatively new it is a most destructive disease, and was referred to in the House of Commons by the Vice-President of the Irish Department of Agriculture as " that terible disease known as Black Scab." It is more of the nature of a "wart " then a "scab," and, from the lixuriant growth on the surface of the tuber, it has sometines been called the Cauliflower Disease. It is regarded as one of the most serious diseases with which the potato-grower has to contend, since it is stated that no sound tubers have been saved from a crop which has been attarked. Unfortunately, it is not noticed until the crop is being harvested, and it is, therefore, liable to contaminate the ground without being observed. When fully developed the disease is easily detected, but in the early stages the tubers may appear sound although the "eyes" are affected.

The disease is spread by means of diseased tubers introduced from infected areas, and, therefore, only sound potatoes should be planted. Also by animals, such as pigs and poultry, and a common means is by the use of manures from animals, especially pigs, fed on raw "warty" potatoes. Even the implements used in cultivating infected soil may carry it to clean ground. The warts may continue to develop even when the tubers are stored. 
As regards treatment, various fungicides have been tried without effect. "Variety tests" have also been made, but it is found that the more genera!ly grown varieties are very susceptible. In the Journal of the Board of Agriculture for 1910, it is stated that the disease is checked by "greening." "Of six diseased potatoes, allowed to germinate in the light for a few weeks, and then planted, only one was affected, while, of six not previously germinesed, five were diseased.

Dr. J. H. Wilson, of St. Andrews University, records this disease for Scotland as early as 1901, when it was also first reported in England. A Federal proclamation has been issued, prohibiting its importation into Australia, and the common names applied to it are potato canker, black scab, warty disease, and cauliflower disease (Figs. 67, 68).

\section{Scurf or "Dry Scab" (Spondylocladium atro-virens, Harz = Phellomyces sclerotiophorus, Frank).}

This "scab," or seurf, appears in the form of larger or smaller patehes of various colours, either whitish or light-brown. When these patehes are numerous or confluent, the scabbing becomes very prominent. On these discoloured patches dot-like sclerotia occur, forming minute black specks, just visible to the naked eye. The sclerotium may appear on the same potato with that of Rhizoctonia, but the one is easily distinguished from the other. In Rhizoctonia the sclerotia are much larger, more conspicuous and projecting, and the cells are at least twice the diameter.

The fungus insinuates itself between the different layers of the skin of the potato, causing them to peel off like tissue-paper, and this exposes the tissue beneath. Under these conditions, dry rot may follow the "seab."

The disease may either be introduced by means of infested tubers, or the fungus filaments may pass from the soil on to healthy tubers (Fig. 69).

The foregoing account of the varied forms of skin disease emphasizes the necessity for determining the nature and mode of working of the agent responsible for the effects, before any measures for prevention can be devised with a reasonable hope of success.

$$
\begin{aligned}
& \text { (Plates XIV., XV., XVI., XVII., XVIII., XX., XXI., XXII., XLIII., } \\
& \text { XLIV., XLV.). }
\end{aligned}
$$




\section{V.-DRY ROT AND "BROWN RING."}

(Fusarium oxysporum, Schlecht. = Fusarium solani, Sace.).

The disease to which this name is applied varies in its symptoms at different stages, so that it has been variously named by growers. There was a serious disease of the potato brought under my notice some years ago, called the "Brown Ring," and it caused considerable loss in seasons when it was prevalent. The smooth-skinned variety Beauty of Hebron was particularly subject to it. The brown ring was so called because on cutting across stored potatoes particularly, the area occupied by the vessels was found to be discoloured, being brownish or blackish (Fig. 89). When the tissue from this brown ring is examined under the microscope, the walls of the vessels are seen to be the portions discoloured, and when a slice from such a diseased potato is placed under a bell-jar, and kept moist, abundance of white fungus filaments are developed, which in cultures produce a Fusarium (Fig. 148). The surface of some of the potatoes that had been stored was also covered with a white mould belonging to the same fungus, and bearing abundance of conidia (Fig. 72).

Hence the disease is sometimes also called the "White Rot," and the generally-used torm of "1)ry Rot" indicates that the tubers become shrivelled and transformed into a dry, somewhat hard, crumbling mass of a greyish colour, if bacterial decay does not set in.

\section{Fungus causing 1)isease.}

The fungus cansing this disease has been variously named. It is commonly known as Fusarium solani, Sace, but some consider that the fungus earlier named by schlechtendal Fusarium oxysporum is the same. I have adopted this name because the reproductive bodies or conidia produced in some cases are very acnte at both ends, as in this species.

The disease has also been attributed to Nectria solani, Reinke and Berthold, considered to be the complete stage of the above fungus, but no such fungus has been found associated with it in Australia, even although diseased specimens have been kept for some time under observation.

\section{Nature of Fungus.}

The fungus usually enters the plant through the roots, thence into the underground stems bearing the tubers, and through them into the tubers themselves. The mycelium or spawn is colorless, and composed of comparatively slender filaments, with numerous partitions, and much branched, as it ramifies anong the cells. When it appears at the surface, in the form of tufts, it may either be snow-white or of a pinkish tint, and bears immumerable conidia. These conidia are borne at the end of the numerous branches, and are usually slightly curved, with three to five septa or partitions, the average number being three. (Fig. 74.) The conidia are pinched off at the ends of short branches, and as they fall away when ripe, others are formed in their place (Fig. 73). It is difficult to say how many may be formed in this way, but as many as five have been counted produced by the same branch, so that the supply of conidia must be practically unlimited during the growing season. But this is only one of several modes of reproduction, as shown when the germination of one of these conidia is ollowed. 


\section{Germination of Conidia.}

The eonidia germinate very readily in moisture, but they only retain their germinating power for a limited period, how long has not been actually determined. Conidia taken from potatoes placed in store in July, 1909, failed to germinate when tested on 30th March, 1910, even after being kept under favorable conditions for seven days, so that eight months after they
had lost their vitality.

A number of germinating tests were made with fresh conidia, to see the time required for successful germination. When placed on a slide in tap water, germination took place in three hours, and filaments were produced from one, two, or three cells of the conidia. In some instances there was luxuriant germination in sixteen and twenty-four hours, and sometimes, with conidia from the same potato, there was only slight germination at the end of eighteen hours, the result probably depending on the different temperature of the laboratory on the date at which the test was mode, as well as the age of the spore. All the experiments were carried out between 1st and 14th April. As a final test, six slides with conidia were plased, under similar conditions of moisture at the same time, and in twenty-four hours there was luxuriant germination in all of them, only about 1 per cent. failing to germinate. Germination takes place either at one end of the eonidia, or at both ends, or laterally. About 80 per cent, germinated only at one end, 10 per cent. at both ends, and the remainder laterally as well, but none germinated from the median cells alone. (Plate XXIV.).

The effect of formalin on germination was also tried. Conidia were placed in a solution of formalin ( $1 \mathrm{in} 40$ ) for five minutes, and then rinsed with clean water. Thousands of conidia were thus treated, but, after several trials, no gemrination took place, even at the end of seven days.

The ordinary mode of germination consists in the production of Iong, slender, septate filaments, which usually give rise to longer or shorter branches, without any further development outside of the potato-plant, but in some cases a short secondary conidim was produced at the end of a branch at a short distance from the primary one. (Fig. 79.)

\section{Conidia in Chusters.}

The arrial conidia are formed in the manner described, under normal eonditions, but when the conidia are placed under relatively dry conditions, with just sufficient moisture to enable them to germinate, then they behave
differently.

On a potato which had been inoculated and kept dry under a jar for seven weeks, there was a dense, white Fusarium mould. Conidia taken from the surface of the mould were found to be germinating and producing filaments bearing conidia in turn. The conidis, however, were not produced sslitary or in chains at the ends of branches, as in the ordinary form, but in clusters, and the filament continued its growth and produced another cluster, and so on. When seen in dry air, these filaments looked like knotted cords, and whenever water touched the conidia they fell away. These knots were oval in shape, and consisted of numerous conidia (sometimes as many as thirty were observed) arranged longitudinally around a central conidium produced at the end of the filament. The conidis in the same cluster were at different stages of growth, some being without and others with septa, the youngest being invariably in the centre. They were straight or slightly eurved, septate or non-septate, just as in the ordinary form, only they were not so fully matured (Fig. 81). 
Sometimes the tufts of conidia, instead of being borne in suceession along the length of the filaments, were produced at the tips of short lateral branches, which were given off in regular order along one side.

The same kind of germination was produced artificially when eonidia were placed on damp blotting-paper, sufficient moisture being present to keep them from drying up. The conidia were taken from the same potato, not from the surface where there was a white efflorescence, eonsisting of conidia germinating as above, but from a pale yellowish mojst substratum beneath that and next the skin, in which the conidia were still germinable. The amonnt of conidia produced in this way at the surface of the mould must be ellormous.

\section{Resthy: SPOREs, or ChlaMydospores.}

The fungus is thus able to adapt itself either to moist or dry air, and reproduce itself lixuriatly under these conditions. But even when submerged, or kept very moist, the conilia are still capable of germination, and produce reprodactivo bodies, which are able to persist, until more favorable conditions arise. These bodies are commonly called resting spores, or chlamydospores, because they are thick-walled, and are more resistant to unfavorable comditions than the ordinary conidia. (Plate XXV.)

() a d potato infested with the fungus, and which had been kept under moist conditions for fully two months, the resting-spores were found in great abundarce. It had become quite soft and stushy, and large patches of a dirty-white or wastateather colour appeared. These indicated the resting-speras. as shown in Fig. 86 . They are seen in all the different stages of developmont, as solitary at the end of a filament, or several in succession forming a chain, or even as a swelling in the course of a filament.

When the ordisary conidia were placedunder water, they began to geiminate in the course of three hours. They either put forth a slender germtube as usuai, or this might be entirely suppressed; but the peculiarity consisted in the formation of reproductive bodies different from the conidia producing them within six to seven days. Resting-spores usually arise as swellings of the hyphae, either on long, generally straight, filaments, or on short lateral branches. There may be several together like a string of beads, or they may arise at the end, when they are terminal, and may either be solitary of form a chain. They may even arise direct from the eonidium without the intervention of a germ-tube, either laterally or terminally. (Figs 82, 83, 84.)

The Figures show the wonderful variety in the mode of formation of these resting-spores. They may be produced direct at one end of a eonidium, and a germ-tube at the other, or a germ-tube may be formed at either end, and the resting-sporie laterally, or even the germ-tube may sometimes produce a lateral as well as a terminal spore.

The mature resting-spore is a splerical or ellipsoid body of a yellowishbrown colour, with a wall sometimes three micro-millimetres $(\mu)$ in thickness, warty, irregular, or smooth. It varies in size from 8-13 $\mu$ when attached, and when fully mature and detached, 16-22 $\mu$. (Fig. 85.)

\section{IneECTION OF Potato BY Potato.}

There has been some doubt expressed as to whether this fungus aetually causes the disease, and Massee, even in his "Text-book of Plant Diseases" (1909), dismisses thesubject with the remark, "Fusarium solani Sace. is said to cause the rotting of potato tubers, but the matter requires further investigation." lixperiments have been carried out by various investigators showing that healthy potatoes may be infected from diseased ones, and the matter has also been investigated by myself. 
The healthy potatoes used in this experiment belonged to the variety known as Carman No. 1. That they were absolutely free from this disease was clearly shown in the first experiment, in which one of the potatoes was deeply cut with a sterilized knife in various places, and the end cut off, so as to expose a large cut surface. The specimen was kept moist under a belljar, and at the end of 24 days it was found to be perfectly clean. (Exp. 1.) In the next experiment one of these healthy potatoes was infected from a diseased one. Pure conidia were placed on the unbroken skin at the base of the "eyes," and in seven days Fusarium appeared on the young shoots, causing their tips to become brown and withered. So that a young potato shoot could be infected in this way, causing it to die off, but the tuber itself was not then appare itly affected. (Exp. 2.) When, however, a healthy potato was infected where the skin wes broken, an abundant growth of the Fusarium was obtained in seven days, together with symptoms of "dry rot" in the tuber. (Exp. 3.) Even when the skin was unbroken infection night occur. Very young healthy potatoes, about the size of peas, were inoculated on the unbroken skin, and in four days the Fusarium appeared. The fungus not only caused a browning of the skin at the spot where infected, but had penetrated beneath the skin and caused a slight browning of the tissue. (Exp. 4.)

It is evident, therefore, that healthy potatoes can be infected from diseased ones, especially when the healthy potato is wounded either in digging or otherwise, and very young potatoes with a tender skin can be infected even although the skin is unbroken.

\section{Irfection of Potato By Tomato.}

A clean potato, with unbroken skin, was infected with conidia from the tomato on a portion of the surface away from the "eyes," but it was still clean after 24 days. (Exp. 5.) When a clean potato, however, with broken skin was infected fron the tomato, infection took place in six days, and the conidia of the fungus appeared. (Exp. 6.)

The potato can, therefore, be infected by the conidia of Fusarium, whether they arise from the potato or tomato, and the next step is to see if the tomato car be similary infected.

\section{INFECTION OF ToMato BY Tomato.}

A clean tomato, with broken skin, was kept as a check, and at the end of 24 days it was still clean. (Exp. 7.)

A clean tomato, with unbroken skin, was infected, and in fourteen days the conidia of the fungus appeared on the surface. A small sunken circular spot appeared at the end of ten days, and in 24 days one end of the tomato was covered with a pure white crop of Fusarium, and a softening took place all around it. (Exp. 8.)

Infection took place much more quickly when the tomato was wounded. When the tomato was inoculated on a wound the Fusanium appeared in six days, and at the end of 24 days the tomato was soft and decayed with a erop of mould covering the top. (Exp. 9.)

\section{Infection of Tomato By Potato.}

A healthy tomato was infected on the unbroken skin, and the fungus was produced within 24 hours. Up to five days the Fusarium alone appeared on the surface, but after that other fungi appeared as scavengers and completed the decay of the tomato. (Exp. 10.)

Finally, a healthy tomato with the skin broken was infected at the wound, and within 24 hours the Fusarium appeared, as shown in Fig. 90. (Exp. 11.) 
Table IX. - Mutual Infection of Conidia from Potato and Tomato.

The preceding experiments show that the conidia of Fusarium on potatoes and tomatoes are mutually infective, just as the Phytophthora infestans can also pass from one to the other.

The following table summarizes the results obtained when specimens were kept moist under a bell-jar :--

\begin{tabular}{|c|c|c|c|}
\hline No. & Experiment, & $\begin{array}{l}\text { Source of } \\
\text { Infection. }\end{array}$ & Result. \\
\hline 1 & He:lthy pot to, with broken skin .. & & Still clean after 24 days \\
\hline 2 & $\begin{array}{l}\text { Healtliy potito, infected on unbroken skin at } \\
\text { eyes }\end{array}$ & Potato & $\begin{array}{l}\text { Young shoots only } \\
\text { affected and produe- } \\
\text { ing mould in } 7 \text { days }\end{array}$ \\
\hline 3 & $\begin{array}{l}\text { Healthy potato, with broken skin, infected at } \\
\text { wound }\end{array}$ & ", & $\begin{array}{l}\text { Fungus produced at } \\
\text { wound in } 7 \text { days }\end{array}$ \\
\hline 4 & Very young potnto, with unbroken skin, infeeted & ", & $\begin{array}{l}\text { Fungus appeared in } 4 \\
\text { days }\end{array}$ \\
\hline 5 & $\begin{array}{l}\text { Healthy pot to, with unbroken skin, infected } \\
\text { away from "eyes" }\end{array}$ & Tomato & Still clean after $24 \mathrm{~d} s \mathrm{y} s$ \\
\hline 6 & $\begin{array}{l}\text { Healthy potato, with broken skin, infected at } \\
\text { wound }\end{array}$ & ", & $\begin{array}{l}\text { Fungus appeared in } 6 \\
\text { days }\end{array}$ \\
\hline 7 & He.tely tom to, with broken skin . . . . & & Still clean after 24 days \\
\hline 8 & Henlthy tomato, with unbroken skin, infected & Tomato & $\begin{array}{l}\text { Fungus appeared in } 14 \\
\text { days }\end{array}$ \\
\hline 9 & $\begin{array}{l}\text { He Ithy tom to, with broken skin, infected at } \\
\text { woind }\end{array}$ & ", & $\begin{array}{l}\text { Fungus appeared in } 6 \\
\text { days }\end{array}$ \\
\hline 10 & Halthy tomits, with unbroken skin, infected & Potato & $\begin{array}{l}\text { Fungus a ppeared in } 24 \\
\text { hours and tomato } \\
\text { ultimately destroyed }\end{array}$ \\
\hline 11 & $\begin{array}{l}\text { Healthy tomito, with broken skin, infected at } \\
\text { wound }\end{array}$ & ," & $\begin{array}{l}\text { Fungus appeared with- } \\
\text { in } 24 \text { hours }\end{array}$ \\
\hline
\end{tabular}

It will be observed that the tomato, whether with broken or umbroken skin, was readily infected with conidia from the potato; but when conidia from the tomato itself were used, infection was much slower. The potato, on the other hand, with broken skin was not infected for six or seven days, whether conidia from potato or tomato were employed, and with unbroken skin infection did not occur, unless in the case of very young potatoes with tender skin, or when applied to the "eyes" of mature tubers. Massee has noted the appearance of this fungus on the tomato plant, causing the nondevelopnient of the flowers and the withering of the inflorescence.

Recent experiments were also carried out by Pethybridge and Bowers, which proved conclusively that healthy tubers may contract the disease by contact with the diseased ones, and, to establish the parasitic nature of this fungus beyond dispute, pure cultures were used. The results may be given in their own words:- "The certainty and ease with which these wound-inoculations with pure cultures succeeded, made it unnecessary to cary the matter further, and it is quite clear that Fusarium solani is a true parasite capable of directly producing the disease known as 'dry rot' in absolutely healthy potato tubers. The tuber's developed the disease in a perfectly typical manner, and eventua!ly became totally shrivelled up to a dry hard mass."

From the study of the diseased potato plant itself, as well as of the tuber, there are seen to be various modes of infection. The fungus enters the plant beneath the surface of the soil, through the roots to begin with, whence it can easily spread to the base of the stem, then to the underground branches, and finally to the tubers at the end of them. The fungus must therefore be in the soil in some form, probably as resting-spores, and the germ-tubes from them will penetrate the delicate rootlets, and utimately reach the tubers. 
This roundabout way of reaching the tuber is not always necessarily followed, for the shoots of the seed potato may be directly infected from the germ tubes of the conidia planted with it, and the filaments of the fungus would directly pass through the underground portions of the stem into the tubers. But there is even a more direct way of infecting the tubers, for the fungus may enter through wounds, or even through the unbroken skin when young and tender.

Dry rot is generally regarded as a disease of the tubers only, but it may also attack the "collar" of the stem and cause rotting there.

\section{Life History of the Fungus.}

The life history of this fungus, as occurring in Australia, may be briefly summed up as follows :-

1. Fusarium stage.-Under normal conditions of heat and moisture the mycelium or spawn of the fungus inside the tuber produces its fructification on the surface of the skin in the form of snow-white tufts, bearing innumerable curved and jointed conidia. When these are placed on a healthy potato, where the skin is broken, or even on the unbroken skin of young potatoes, they germinate and enter the tuber, again producing the Fusarium stage at the surface in the course of four days. (Figs. 72, 73.)

2. Cephalosporium, or Cluster stage.-On a potato, which had been inoculated with the Fusarium conidia and kept for seven weeks, the dense white mould which appeared on the surface produced conidia somewhat differently from the preceding. Instead of being solitary or in chains, they were in round or oval clusters, either at the tips of short lateral branches or in succession along the same filament. The individual conidia were curved and jointed as in the Fusarium stage. Conidia were taken from the same potato and germinated artifically on damp blotting-paper, just sufficient moisture being present to prevent them drying up. They produced the chustered conidia as above, and thus the mycelium is capable of forming either solitary or clustered conidia, according as the air is moist or relatively dry. (Fig. 81.)

3. Chlamydospore, or Resting-spore stage.-But even when completely submerged or kept very moist, this fungus is still capable of reproducing itself. Under these conditions it forms rough, brown, thick-walled spores, known as Resting-spores, because they are able to tide the fungus over unfavorable conditions. They are either produced in succession along a filament like a string of beads, or they may be formed at the end of a branch either solitary or in chains. They have been produced directly at the end of a conidium, so that there is no doubt as to their origin, but I have not yet followed out their germination. (Figs. 85, 86.)

\section{Preventive Measures.}

Although we do not know the complete life-history of this fungus, there is sufficient information to guide us in making recommendations. How long the fungus keeps alive in the soil has not been determined, and how long the spores retain their vitality is not known, but it has been proved that healthy tubers can contract the disease from the soil.

1. There is a counsel of perfection which can be given with safety in this as well as other potato diseases, and that is to plant only sound tubers obtained from localities where the disease does not occur, and plant in soil free from the fungus. 
2. It would be difficult to carry out the above in practice, but in order to avoid the infection of healthy land by diseased tubers the stem end of every tuber intended for seed should be cut and inspected before planting, and any showing "brown ring " should be rejected and destroyed. Cut seed would thus have the advantage over whole seed, as it would show any discoloration inside the potato.

3. Infected land should not be planted with potatoes for a series of rears.

4. Iniseased tubers should not be thrown on the manure heap.

5. T'ubers should be stored in a dry, cool, well-ventilated place, since heat, moisture, and the exclusion of air are conditions favorable for the development of this disease.

6. It is well known that this disease often develops in store; therefore any suspicious-looking tubers should be rejected when digging, and not stored.

7. Stored potatoes should be frequently turned over, so as to detect any appearance of the disease, and remove such affected tubers at once. Massee recommends the sprinkling of powered sulphur over the potatoes at the rate of abont $2 \mathrm{lbs}$. to the ton in order to check the development of the fungus.

8. As wounded surfaces are very liable to infection, care should be taken when digging, and afterwards handling, to avoid wounding the tubers.

9. From the risk attendant on wounded tubers, they should not be used as seed.

10. Nince steeping the conidia for five minutes in formalin solution ( $\mathrm{I}$ in 40) prevents their germination, treatment of the seed potatoes in a similar way would destroy the germinating power of any adhering to the surface of the tuber.

11. Some varieties, such as S.rowdîp, are very susceptible to the disease, and a selection from resistant plants of other varieties might be made.

(Plates XXIII., XXIV., XXV., XXVI., L.). 


\section{VI.-WET ROT, BROWN ROT, SORE EYES, OR BACTERIOSIS.}

\section{(Bacillus solanacearum E. F. Smith.)}

This is a type of a class of diseases which are very destructive in their effects, and which are only beginning to be studied, so that the number is being added to year by year. They are caused by microbes or bacteria, and numerous instances are known where these organisms simply act as scavengers, and only appear after disease has been set up by some other means. The great majority are of this nature, and it has even been called in question whether they ever originate disease: but there are several well-known cases in which they are proved by infection experiments to produce the disease, and this is one of them. The great secret of their success as plant-destroyers lies in their immense powers of multiplication, and it has been reckoned that a single tobacco plant affected with the same disease as the potato may contain ten thousand million of these bacteria. 'The disease has been known for a number of years in Australia, and is familiar to growers from the offensive odour associated with it, as well as the shushy "rot" which sometime. entirely fills the skin of the potato, so that on bursting nothing but a putrid mass oozes out. It spers out like rotten, clotted cream.

It also occurs in Britain, and is well-known in America, where it has been thoroughly investigated from the bacteriological point of view by Dr. Erwin F. Smith.

Although this disease first became generally known through the comprehensive description of it by $\omega_{r}$. Smith, published by the United States Department of Agriculture in December, 1896, in a bulletin entitled "A Bacterial Disease of the Tomato, Egg Plant, and Irish Potato," yet it had previously been discovered and investigated by Mr. Tryon, Government Entomologist and Vegetable Pathologist of Queensland, who made known the true nature and cause of it as early as May, 1894, in a "Preliminary Report on a new Potato Disease prevalent in Southern Queensland." In a further paper in the Queenstand Agricultural Joumal, July, 1899, he showed conclusively that the American and Australian diseases were identical, and that the same bacterium occurred in connexion with both, viz., Bacillus solanacearum, the new species determined and named by smitl.

\section{SYNPTOMS.}

The first indication of the disease is the sudden wilting of the foliage, and the shrivelling of the leaves is soon followed by a discoloration of the stem. (Fig. 97.) Dark-brown streaks are seen, and these gradually pass downwards into the underground branches, and so ultimately reach the tubers themselves. It is only when it has reached and affected the tuber that the disease is usually taken notice of by the grower, but it may just as readily be detected in the discolored stems.

When the stem is cut across in the early stages of the disease, the woody cylinder is seen to be brown and discolored, with the slimy, dirty-white bacteria oozing out all round. (Fig. 97.) The tuber may at first appear perfectly sound, but, on making a section of it towards the stem end, there is seen a more or less complete pale-brown ring, situated a little inward from the skin, as in Fig. 97z. Then this broadens and darkens in colour, until the ring may even extend to the skin as well as inward. (Fig. 94.) There is no risk of confounding this with the "brown ring" due to Fusarium, for there is the grayish-white bacterial slime oozing out. When some of the potatoes. 
from which the photrographs were taken, were plased in spirit, the extraction of the water and the consequent shrinking forced the bacteria out throngh the eyes in large (moling musses. (Fig. 9.).) The solid masses of bateriasupplied visiblevidenceof theirimmonse numbers. Liven while still unclereronnd there is an exudation from the eyes, which on account of its stirky nuture ranses the earth to whluere at these points, so that when

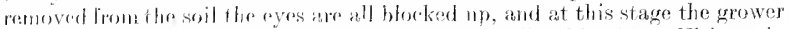
gives the discase the explessive hame of "sole eyes." (Fig. H1.) Dltimately The pestateres becomin as secthing mass of cormption, and, when dug, you can see then with the mulnokm or lorken skin, and the dirty-white slimy fluid stresming out, pollutiug the air with an offensive odour.

The indieations which may be relied on, are the following:-

(a) A wiltine ol tlur platst.

(b) $A$ watring ef the oyes, associnted with a frothy exudation.

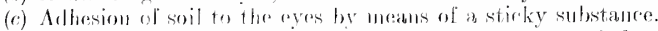

(d) A bown of back lot remmencing at the stem end of the tuber in f.he vascolat ring and extending in all directions.

\section{CAISL.}

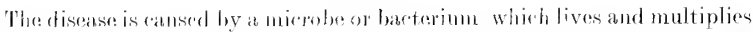

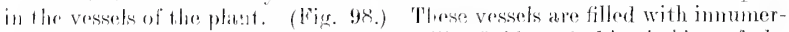

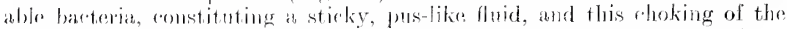
vesscels prevents air and antriment being distributed thomghent the plant, so that the tops wilt and dire whild the tubers berome disensed. It does not

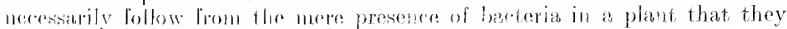

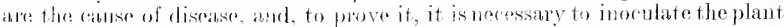

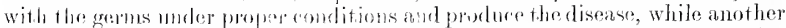
plant. grown moler similar enditions, but without being infected, remation healthy. Pure cultures of this oreatism were used to infect the potato plant, and in filteen days fle wilting orenred as shown, white the bealthy uninfected

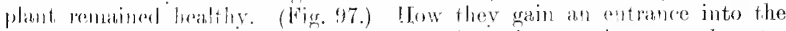

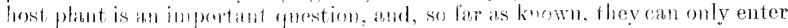
thomeng wommds.

\section{NATTRE OF THE ORGANISH.}

T'ine imume powers of multiplication possensed by these organisms, combined with theip ability to dissolve the cell-walls of plants and set up putrofactive chameres, muler then very destructive. Another factor of considerable importanes is their power of contimuing to live and grow outside of the potato or other host-plants. The soil in this way may become infereterl, and loaldily plants glown in such soil may contract the disease. When iscolated lom their lasti-plants, lowever, these organisms become less vimlent, and their power of cassing disease may die out altogether; but they are known th retain their vitalify in the soil for a peried of years, and several rases ate racorded where five to eight years' rest of the soil did not prevent a refmor of the disease. They are also sensitive to heat, and Smith states that if the whole body of the soil could be warmed up to 125 degrees Fin? lor filteen mimufes they would be destroyed.

\section{ILOST Plaxt's ANI DISTRIBUTION OF DISEASE.}

This discase ocents on varions members of the Potato family. It has been leternined by 1)r. Wrwin F. Smifl, in the United States of America, on potatoos, fomafores, and egg plants (Solemem melongene), as well as on toluares phats, and a wilting ol the loaves is a charanteristie sign of it. In 
the State of North Carolina, in 1908, it is estimated to have cansed a loss of upwards of $£ 20.000 \mathrm{in}$ the tohacco crop, and it is stated that if it continues at its present rate of progress it will threaten the existence of the tobaccogrowing industry. It has also been recently observed in Britain on potatoes, and it has been found in New Zealand, Queensland, and Victoria on the same crop. In all probability it exists in the other States of the Commonwea!tl. In Victoria it is the cause of considerable loss, and is particularly bad in swampy ground which has been reclaimed.

\section{Preventive Measures.}

As in the case of potato blight, measures have to be directed towards preventing its introduction into a district, as well as dealing with it when it has already appeared. Since bacteria are so ubiquitons, and possess such immense powers of multiplication, the only safe course is to prevent its access to the soil through the seed potatoes.

The following measures are, therefore, recommended:

1. In planting fresh ground, seed potatoes should be obtained from a district where the disease is not known to exist.

2. Seed potatoes may be heated as recommended for potato blight, since that heat is iatal to the organism causing the disease.

3. Potatoes should not be planted on infected land, and even after several years it is not safe to do so.

4. No plants belonging to the Potato family should be used as a rotation on infected land, as even weeds of this family are subject to it.

5. Affected plants should be removed and burned as soon as detected. The longer they are left in a field, the greater the danger of increasing the soil infection.

6. All refuse, such as potato tops and decaying tubers, should be removed and destroyed. I have usually seen the "slushy" potatoes left on the field, as the growers do not realize the risks they run.

7. To prevent the infection of clean fields, care should be taken not to carry the earth from an infected field by means of implements, feet of horses and cattle, on one's boots, \&e. In fact, one should always cultivate a clean field first, and implements should be disinfected, which may be done by a short exposure to live steam, or by means of corrosive sublimate, obtainable in the form of tabloids.

8. The disease may also be transmitted from plant to plant by leafeating or leaf-puncturing insects, and therefore spraying with an insecticide would indirectly check the disease.

9. The wettish spots in a field are generally the worst affected, showing that drainage, while not an absolute remedy, has a beneficial effect. 


\section{VII.-"BLACK LEG" OR "BLACK STALK-ROT." \\ (Bracillus sp.)}

"Black leg" is the popular name given to this disease, but since it is also applied to a well-known disease in cattle in this country, and to a eommon disease in rabbage and caulifiower, the suggestion has been made to call it "Black stalk-rot." Although we talk of "scab" in sheep, it does not cause any confusion to apply it to potatoes, and so "Black leg" is such an expressive name for the disease that it is adopted here. This disease affects all parts of the plant, causing the stem and leaves to assume a yellowish-green colour, then to turn brown, and fimally the leaves collapse and dry up. The entire plant dies down, and the underground portion of the stem shows the seat of the trouble. This is quite black and decaying, so that it is readily understood how the leaves gradually die from below upwards, and the stalks collapse. The result is that no tubers, or only very small ones, are developed. When affected plants are dig up, the "set" or seed potato is found to be completely rotten.

Signs of the disease may appear as soon as the plants are above ground, or at any intermediate stage up to flowering time. It may be confined to only one stalk of a plant, or all the stalks of the same plant are frequently attarked. especially when the disease has rearhed its full development. In later staces of the disease the rellowish or pale-green colour of the leaves is, as a rule, very conspicuous. It is usually only plants here and there that are affected, but it may be so commonly distributed that the yield is serionsly reduced, sometimes even to the extent of 75 per cent.

\section{Calse of the Disease.}

If the blackened portion of the stem underground, in the early stage of the disease, is examined, the tissues are found to be decayed, and more or less soft and rotten. But if the firm portion above the level of the ground is cut across, the section shews three dark-brown spots. These spots indicate the vascular bundles of the stem, which lave become disorganized through the action of organisms. In fact, one finds various organisms associated with the decay; but if this is followed up to the boundary of the sound tissue, there the presence of bacteria is decidedly in evidence. The young tubers may also have black patches, and the vasenlar ring often shows a black discoloration. The damp, muggy weather, which favours potato blight, eauses this disease to spread rapidly, and numerous speeimens were sent to me during the past season along with the other.

10r. Appel has named the speeific organism causing this disease in Germany Bacillus phytophthorus, and what is probably the same disease in Canada is said by Harrison to be caused by $B$. solanisaprus. Dr. Pethybridge has found a similar disease in Ireland caused by $B$. melanogenes, and the distinct species causing it in Australia will require to be settled by the Plant Bacteriologist, whenever such an officer is appointed.

\section{Distribution.}

Althongh this disease has only been specially noticed this season (1910), occasional specimens have been sent to me in previous years. It is known in Britain, as well as in France and Germany, where it is popularly known as Schwarzbeinigkeit, or Black Leg. Also in the United States and Canada, and probably in other States of the Commonwealth besides Vietoria. 


\section{EFFECTS.}

Although the disease was only observed in the growing crop in isolated plants here and there, and the loss from that source was therefore not serious, yet it may also occur in stored potatoes, where the loss might be considerable. Pethybridge and Murphy have proved experimentally that perfectly sound tubers may become infected by contact with diseased ones; so that, under suitable conditions of heat and moisture, very serious rotting might occur.

In some cases the disease in the tubers may be so slight that they may be planted as "seed" potatoes, but the parasitic bacteria will become active and produce the rotting of the stalks sooner or later.

\section{Preventive Measures.}

Bacterial diseases are, as a rule, difficult to cope with, on account of the immense powers of multiplication possessed by the microbes, and the rapidity with which they are spread. Hence, whatever measures tend to limit their numbers or prevent their spread, should be adopted. The use of formalin or bluestone solution has not been found to be beneficial, since they do not penetrate the skin of the potato and reach the bacteria in the interior.

1. The decaying and rotting parts of the plants are swarming with bacteria, and in order to prevent the soil becoming contaminated with them, they should be removed as soon as they show symptoms of the disease and burned.

2. Healthy seed should be selected by picking the tubers from healthy plants when the crop is being lifted, and placing them in boxes for sprouting at once. Or, better still, the seed potatoes should be obtained from districts free from the disease.

3. The potatoes should be planted in well-drained land, or in land not likely to become water-logged. The diseased specimens photographed were obtained from reclaimed swampy land, and the water could be pressed out from the soil by squeezing it in the hand.

4. There should be a rotation of crops. If potatoes are planted in the same soil year after year, they are liable to increase the chances of infection, and to eneourage the multiplication of the bacteria. Cereals are not subject to the discase, but, according to Dr. Appel, who has made a special study of the subject, beans, beet, carrot, cucumbers, mangolds, turnips, and vegetable marrows are all susceptible to it, and should not, therefore, follow potatoes on land where the disease has occurred.

5. Lime and strong nitrogenous manures should be avoided, as they encourage the disease.

Pethybridge, as the result of his studies, has stated that "preventive measures should, therefore, aim at the destruction of diseased plants, the exclusion of affected tubers from the pits, and the procuring of tubers for "seed 'purposes from crops in which the disease has not appeared." He is also testing experimentally if the organism ean be killed by heat without injury to the tubers themselves, and since the thermal death-point is not above 50 degrees C. (122 degrees Fahr.), this can be safely done. 


\section{VIIL-BLAOK IOT DINEASE. \\ (Vermiculerie varians Duc.)}

Towards the end of January potato plants were brought under my notice which had grown luxuriantly, but afterwards the stems became dry and the green leaves shoivelfed up. Pltimately the stem became continuously and densely rovered with minute black bodies, either separate or confluent, and these black points ronstitute the essential charateristics of the disease. The black dots exfruded to the tips of the underground portions, but they were not conspicuons on the tubers or leaves.

In May a potato plant belonging to the White Elephant variety was brought under my notice, which had been grown in aspecially prepared soil, reaching a lreight of 11 feet, and bealing several large tubers. This discase was fombl upon the stems, and since the seed potatoes were brought out from Einglanel a fow years ago, it was probably in this way that the disease eached Australia. The sume plant was also affected with Trish Blight. both in tops and tubers, and probmbly both diseases were introduced together. $A$ disease of potatoes and tomatoes wasdescribed in France in 1909 caused by the sane fungus, but it law nof been recorded on the tomatoes here. It was not olserved at fisst on the tuhers; in fiact, the potatoes were well-grown and atpparently sonded, and it was this disecepancy between the healthy tubers abld discased tops which attrasted the attention of one of our inspectors.

\section{sympous.}

This discaluse appeans on the stens while still quite green (Fig. 141), and it is the lower portions of the plant which are first attacked. It descends to the roots and (orepss up the stem, until finally they blacken and become quite inittle. Iltimately the stalks are quite black and dead, and the leaves are all brown and shrivelled up. (Figs. 137, 138, 139.)

The b]atk dots not only occur on the root and stem, but, when the withered leares are carrefully examined, they are also fomd on the leat-stalks as well as on the leaflets.

There is usmally a fair crop of potatoes, which are fully formed and apparently healthy. Hhen carefully examined, especially towards the stem end, the skin is dotted all over with minute black dots (Fig. 140), which, on microscoppic examination, show the characteristic features. These dots occur on the tubers at all stages of growth, on the young as well as on the fully formed, and they can be seen passing from the stalk to the skin of the potato. Hence they are most mumerous at the stalk end, and towards the crown end they may be absent or only a few scattered ones.

The course of the fungus can be readily followed. It covers the stems even to the extreme tips, then passes along the underground branches to the tubers, and extends from the stalk over the potato. The selerotia are also developed inside the hollow stem, but they never reach above ground, and extend along the inside of the underground branches to the tubers.

\section{Fungus Causixg Disfase.}

The fungus causing this disease assumes various phases, and the black, dot-like form is only one stage of its life history. It first appears as minute white tults on the surface of the stem, eonsisting of short, colourless filaments, bearing colourless conidia or reproductive bodies at the top. From the base of these tuits a number of black rigid hairs grow out, which are slightly swollen at the base, and tapering towards the apex. Then underneath the skin, and often below the preceding stage, black solerotia-like bodies are produred, which ultimately burst through and form the black dots studding the surface. 
When sections of these black bodies are examined, they are seen, as in Fig. 142, to be solid sclerotia, with numerous black rigid hairs on top, among which innumerable colourless conidia are being produced, similar to the first forms.

This is the most advanced stage as yet met with in Victoria, but in France the sclerotia have been found developing into mouthless pycnidia, or spore cases, with spores in their interior.

While the selerotia are generally superficial, they become embedded in the tissue of the stalks producing the tubers. The sclerotia produce the colourless conidia under ground as well as above ground, but, as far as I observed, they were not produced there in such profusion. On the dead stems whitish patches often occur, studded with numerous black, superficial flattened pycnidia, without bristles and opening by one or two pores. The contained spores are continuous and colourless, and the fungus is a Phoma, which is probably saprophytic. (Fig. 139.) The tubers were also sometimes affected with "wet rot," even although the black sclerotia were evident upon the surface of the skin.

\section{Effects Producen.}

The blackening of the stems and the browning and shrivelling of the leaves are very evident, and if this takes place before the tubers are matured, it is bound to reduce the yield. But the tubers themselves appear quite firm and healthy, even although there may be numerous black dots upon the skin. If infected tubers, however, are used as seed, the mycelium or spawn may pass into the young tubers and destroy them. The young tubers may also become infected, through sclerotia being in the soil from a previous crop.

\section{Preventrve Meastress.}

From the nature of the disease, all the haulms should be collected and destroyed by burning, since the sclerotia in the soil would perpetuate the disease.

Tubers grown from such plants should not be used as " seed," even although apparently healthy, for the sclerotia are so minute that they could easily be overlooked, especially if few and scattered. A rotation of crops should be practised, since we do not know how long the sclerotia may remain in the soil and retain their vitality.

(Plates XLVIII., XLIX.): 


\section{IX.-SCLEROTYUM DISEASE.}

This disease has been observed occasionally in potatoes, but not to any great extent. In tomatoes, however, it has been very common in some seasons, and caused quite a number of the plants to die right off. When the plants were about full grown, and coming into bearing, they would suddenly wilt and collapse. About the beginning of December, 1909, some potato plants were observed to have prematurely decayed, their leaves becoming wilted and shrivelled up. On slitting up the brittle stem, it was found to have rows of black bodies inside, varying in size and shape from that of a pea to a grain of wheat. The one photographed was about three-eights of an inch in length, and covered in parts with a whitish mould. (Fig. 100.) This is known as the sclerotium stage of the fungus, and consists of fungus filaments, tightly twisted around each other into a compact, dark-coloured mass, which, however, is white in the interior. (Fig. 101.) This is the restingstage of the fungus to carry the disease over the winter, and when ripe the black bodies fall to the ground, where they are able to withstand adverse conditions until the time for their further development arrives. At present these bodies are being kept on moist earth under a bell-jar, but, so far, no change has taken place. 


\section{X.-STRINGY ROT. \\ (Armillaria mellea Vahl.)}

Occasionally the potato is found to be more or less covered with brownishl strands, like so many cords, and they may even grow beyond it to a length of six or seven inches, as shown in the ascompanying photograph. (Fig. 102.) These coarse, brown strands belong to a fungus which grows on the roots of numerous plants, and eventually causes their death, so that it is popularly known as the "tree-killing fungus." It not only attacks forest and fruit trees, but also bushes such as the gooseberry and raspberry, and even herbaceous plants such as the potato.

\section{Nature of Fuxgus.}

By means of these strands it is able to spread in the soil, and pass from one plant to another. In one place, where this fungus was found on the potato, it likewise occurred on the roots of apple trees and vines, and on inspecting some of the "bush drains" made from twigs of the wattle, I found them to be just a perfect breeding ground for the fungus.

When these fungus strands reach the root of a living tree, they are able to bore through the outer bark into the soft bark, and there to spread out like a fau into a mass of soft white filaments. which invade the living layer and destroy it by feeding upon it. These filaments may spread betweell the bark and the wood, either up the sten or along the healthy roots, and in course of time the tree dies, becanse the roots no longer serve their proper function and nourish it. In the case of the potato these white filaments are formed beneath the skin, and the flesh becomes brown, because the cells are killed by the fungus.

Towards the end of the growing season, and when the available nourishment has been largely appropriated by the fungus, it may develop fruiting bodies in the form of a well-known toadstool, recognised as the Honey Agaric, and scientifically named Armillario mellen.

\section{How it afeects the Potato.}

Just as this fungus may pass from the roots of native trees to cultivated trees, so in newly cleared ground the potato may be attacked by it, and once having gained a footing it is difficult to eradicate. The cord-like strands at first tightly envelop the potato (Fig. 106), and gradually the white mycelium is formed, which peaetrates the skin. (Fig. 107.) There it ramifies annong the starch-cells and brings about their decay and death, so that the flesh of the potato has a brown appearance, internixed with the white filaments of the fungus. Finally the potato may become completely destroyed, and shrivel up into a dry, decayed mass. (Fig. 108.) T'inis disease has been recorded from Tasmania and New south Wales, as well as from Victoria; but it is so conspicuous from the brown cord-like strands that it is readily detected, and the disfigured tubers should at once be rejected and destroyed.

One tuber, quite firm and affected with stringy rot, was found among a number of healthy ones growing on the same plant. The decayed roots of a eucalypt were observed in the soil in contact with it, and not only were the black strands of the Armillaria on the skin of the potato, but the white fungus had penetrated inside, mottling it all through, as shown in Fig. 108.

Preventive Measures.

This is a difficult disease to deal with, because it lives in the soil in decaying roots, \&c., and readily passes to any fresh succulent growth. Well-drained soil is inimical to it, and the ground should be thoroughly cultivated, so that all decaying roots are brought to the surface and burned before planting. 


\section{XI.-BROWN FLECK, OR INTERNAL BROWN SPOT'.}

This disease is generally called brown fleck with us, becanse the affected potatoes when cut ar ross show brown specks in the otherwise sound flesh (Figs. 103, 104, 105), being to all outward appearance quite sound, though the skin is generally somewhat rougher. It is not a brown rot, for such potatoes keep all right, only when boiled the brown specks become quite hard and impair the rdible qualities of the potato.

"There is a discase mentioned in the Journat of the Board of Agriculture lor April, 1910, known as "Sprain" in potatoes, which seems to be increasing. The brown spots are found when the potato is cut across, and on cooking the potiato these spots can be picked out like pellets. It is usually found on a gravelly, but sometines on a sandy soil, and quite absent an a stiff soil. The discase is not conveyed by the seed, and altogether it coreess with the ulse we are now considering.

It was first recorded in Britain as an "internal disease" in 1898, and in Anerica atud Anstralia in 1895; but, like the Irish Blight, it probably exists wherever the potato is cultivated. Why the disease is called "sprain" is sot quite cleat. It is unfortunate, at any rate, as it conveys the impression that it is due to smone mechanical cause, such as a twist or an overstrain.

It is not a parasitic discase, for no organism of any kind has been found mssociated with it, and it camot be transforred to a healhy tuber. Diseased pieces have been inserted into sound potatoes without prodncing any effect, whd diseased tubers have been planted from which healthy ones were modured.

\section{Microscopie: Appearance.}

If ib microsopic examination is mate of the brown tissue, the majority of the welis are found to have collapsed, and there is a marked deficiency of starch graniss, as compared with the surrounding healthy tissue. Although in very bat cases, where the spots lave run together and have even extended to the skin, abel might be mistaken on at superficial view for Irish Blight, yet there are no fungus filaments present. Even with the anked cye the differenee may bedetected, for, when a "flecked" potato is sliced and placed in a moist whimber, the slices herome dry, whereas a "blighted" potate not only producess the fructification of the fungus, but the slices remain moist.

In the brown cliseased tissue the middle lamelle of the rell-wall is stained ly phloroglucin, while the healthy coll-walls are unaffected. This indicates that the walls of diseitsed cells have herome lignified or woody.

Whon maladifo-green is used instead of phloroglucin, the middle lamella of the discased colls is deeply stained, and the brown granular contents also assume a green tint.

\section{Calses Assigned.}

Farious atuses have been assigned for its appearance, but none of them are sufficient to account for it. The soil and the weather, and even the manure, have all been lought forward as probable causes, but noue of them have been found to hold good in every case. It is certainly most prevalent in light loam or sandy soils, but it is observed here that it usually occurs in that portion of the field where water lodges. Rapid growth is said to favont the disease, since the small potatoes or seconds are seldom affeeted, such pofatoes being produced late in the season when growth is slow.

It is atso at ributed to a want of lime or potash in the soil, but here again it las occured where these ingredients were not lacking. Dry weather, asseriated with poor grmwth, has also been mentioned; but in Germany damp weather is said to favour it, although under such conditions it does not 
always appear. It has been observed that if stable manure is applied immediately before planting, it does not occur, but if applied earlier in the autumn, then it is liable to appear.

Some varieties are more susceptible than others, but, on the whole, it must be regarded as a physiological trouble.

\section{SPRAIN OR STREAK DISEASE.}

In the Joumal of Agricultural Scirnce for September, 1910, there is an article by A. S. Horne on "The Symptoms of Tnternal bisease and Sprain (Streak Disease) in Potato," and he distinguishes between the blotch-like and streak-like markings in the flesh. The former, with rusty-brown spots, constitutes the disease known here as "Brown Fleck," and the latter is called "Sprain" in Britain, on account of the streaky appearance. The internal disease varies in appearance from mere brown specks to dark blotches, which may or may not form a comected system. It is interesting to notice that the skin was discoloured in places, with small areas of brownish tissue immediately beneath. The affected cells still retain their starch, but the protoplasm is of a brownish colour, owing to the formation of a gummy substance within the cell. Very young tubers may be affected with this disease well developed, and even at this early stage no organism of any kind was detected in the brown areas.

In the case of Sprain, or Streak-disease the streaks are quite distinct from the blotches, and frequently form a series of curves one within the other. The streaks in tubers badly affected often extend to the margin, and the diseased cells may sometimes be followed right up to the cork, or a lenticel, or a slight wound. Several experiments were carried ont to test if the disease can be transmitted through the seed, and in every experiment it was found that a certain proportion of tubers were affected. But when potatoes were kept in store, neither of these diseases spread, the markings ramaining stationary in the affected, and not appearing in sound tubers.

I had the privilege of discussing the subject of "sprain "with Ir. I. H. Wilson, of St. Andrew's University, when visiting Australia recently as a member of the Scottish Agricultural Commission. He found as the result of his investigations that sprain did not occur in heavy soil overlying volcaicic rock, but generally in light soils over sandstoue. There was also a rertain class of potato less liable to sprain than others, such as the coarser kinds of poorer quality. On the whole, he considered the disease to be due to a check in growth, since it only occurs in certain seasons, and that check in growth is associated with a lightness of the soil. The application of kainit had a marked effect in Iessening the amount of sprain.

\section{Preventive Measures.}

Where a disease, as in this instance, is due to physiological causes, there is no single factor which will account for it, but there is probably a combination of circumstances producing it. In the absence of a definite cause, no definite recommendations can be given for avoiding it, but suggestions may be made which will tend to lessen it.

1. It is certainly not advisable to use affected potatoes for seed, since, whether the disease is transmitted by the seed or not, the presence of it indicates that at least it is a susceptible variety.

2. The use of a potash manure, such as kainit, has been found in Scotland and elsewhere to have a marked effect in decreasing the disease, and may therefore be recommended.

(Plates XXX., XXXI.) 


\section{"MISSES" IN THE POTATO CROP.}

It is not an uncommon occurrence to find in a potato field that, although the rows have been regularly planted with "sets" which to all appearance seemed sound and healthy, yet, when the shoots appear above the ground, there are many noticeable gaps among them. It is not always easy to account for this, for the soil may be generally equal throughout, and the conditions equally favourable, so that the only reasonable explanation is that the "seed" must have been faulty in some way. The reduction in the total yield is sometimes so great that it becomes a matter of importance to determine how far the losses from this cause may be prevented.

I have had occasion to investigate a good many cases where the "misses" were very conspicuous, and, while it has not been possible to determine the actual cause in every instance, ret sufficient evidence has sometimes been cbtained to justify putting it on record here. Of course, when the "set" is found to have rotted away, there is no difficulty in accounting for the deficiency, but, when it is seemingly alike in every respect to those which have sprouted properly, the case is different.

\section{Threaby Eye, Neede Gye, or Siptinde Disease.}

A commonly occurring cause of missing is that of "thready eye, where the "eyes," instead of developing robust and healthy shoots, produce numerous slender threads, as shown in Fig. 96. This tendency to produce the stringy growths of a pale colonr receives in France the appropriate name of Filosité. This is a disease the exact cause of which is unknown. It has been attributed to a parasitic fungus, but no definite organism has been found causing it. There seem to be various causes at work, and bad or defective nutrition is the chief, leading to marked poverty of starch in the tubers.

Mr. Seymour, our potato expert, has been investigating this disease, and he has been in communication with $\mathrm{r}$. La Bergerie, of France, and I am able to present their views.

When ordinary potatoes were planted in very dry soil, so that only small and unripe tubers were produced, and the plants died prematurely, the entire crop suffered from this disease.

Then, again, planting in a cool, moist soil, with exuberant vegetation at the start, followed by a sudden stoppage owing to drought, yielded a crop suffering considerably from this disease, even up to 80 per cent.

The action of manures has not been found to have any appreciable influence on the disease, but the presence of lime has diminished it considerably, sometimes as much as 50 per cent. Lime affects the flavour of the potato very unfavorably, and Bergerie has suggested that, in order to avoid the disease, seed potatoes could be grown in calcareous soils and potatoes for human consumption on sandy soils.

This disease is generally considered to be due to reduced vitality in the "seed," or degeneration, and accompanying this a want of capacity to elaborate the diastase or ferment necessary to render the starch available for the growing plant, while the influence of drought would only be a secondary factor.

Where this disease is very common, a change of seed potatoes from a different kind of soil should be tried, and, of course, affected potatoes should not be planted. 
The grower recognises the presence of "thready eye" in a potato in various ways-

1. If a potato has sprouted, the slender, thread-like, pale-coloured shoots indicate the disease. (Fig. 96.)

2. Or by the production of minute tubers close to the "eye" without any shoots at all. (Fig. 149.) These are called "mules" by the French.

3. But even in cutting the potato for seed there is internal evidence of it. There is not only the usual vascular ring to be seen, but a regular network of dark streaks throughout the entire flesh of the potato, generally radiating from a dark central core, as in Fig. 8s.

\section{RHIzOcToxia.}

Numerous instances have come under my notice where this disease is responsible for " misses." The black specks are so common on potatoes supplied for seed, that it is difficult to get any quantity free from them, and they have been so long regarded by growers as of no importance that tubers so affected are regularly planted. The Carmans are particularly liable to this disease, and, as already shown, it may attack quite young plants at the collar, and canse them to rot away without forming any tubers. To get a regular and even crop without numerous gaps here and there, it will be necessary in the future to avoid planting potatoes with the blackspecks upon the skin, which stand out so conspicuously, particularly when the potatoes are wetted.

\section{Practical Measures.}

There are at least two ways in which a potato planted may fail to grow, quite independent of any organism rendering it diseased. It may either remain dormant, and send out no shoots, or the shoots may be so feeble in their growth that they soon die down. This failure to grow is usually attributed to degeneracy of the potato, but an interesting experiment by the Curator of the Royal Gardens, Kew, showed that this is not necessarily the case. He placed some tubers, which refused to sprout when exposed to the ordinary conditions, in one of the forcing pits, where the average temperature was about 70 degrees Fahr., and in due course all the "eyes " at the erown or apical end of the potatoes sprouted. They were then planted in the usual way, and produced a normal crop. The sluggish tuber required the stimulus of heat to render the diastase active and convert the stareh into sugar for the use of the growing plant.

When the "sets" are too mature they frequently do not dacay, and thus there may be numerous gaps in the crop owing to this canse. To insure the produetion of strong shoots, and thus prevent the possibility of misses, and at the same time insure an early crop, with the likelihood of freedom from disease, the process of "greening" or "boxing" should be adopted. Any weakness in the seed potatoes, such as "thready eye," can then be detected, and only sound healthy tubers need be planted. 


\section{LENTICELS.}

Minute warts may often be seen with the naked eye on the surface of the potato, and these are the breathing pores or lenticels, al ready shown in Fig. 44. When the tubers are kept very moist, as in a wet summer, these openings may assume a white, mealy appearance. (Fig. 150.) The exfessive moisture causes the corky tissue of the skin to swell up at these openings, and the ontermost corky cells to separate. On digging, the tubers are often seen to be covered with white spots. which are puzzling to the grower. These are the loose eells which are pushed out of the pores in great abundance, and form the white, fluffy material at the surfa e.

The protective covering of cork foming the skin of the potato has to be interrupted at various points to admit air, and this at the same time gives access to various fuagi, which ramify among the tissues and destroy them. But the white fuffysporssattered over the surfare of the potato are not in themselves of any sprious import, athough they have been mistaken for fungi, and the apperare is specially noted here to dilay the fears of the allxious grower.

(Piare L.)

NoTE.

O. 16. - In the report of the hotanist, 1)r. G. P. Clintor, of the Conneeticut Agricultural Expecimen station for 1909-10, and issued in June, 1911, there is an article on the Oöspores of Potato Blight, Phytophthora injestans.

He has sucreeded in produring the oöspores in artificial cultures by securing favorable strains of the fungus, and employing suitable media. "The one medium that lias stood alone, so far as production of oöspores is concerned; is our oat juice agar. Without this, apparently, we would never have produced perfert oöspores in cultures."

The production of oöspores is very variable, and on account of their comparative scarcity, the different steps in their development have not been closely followed. The female reproductive organs, or oögonia, are much more common than the male reproductive organs, or antheridia, which are frequently missing, but they are both shown quite distinct in the photographs, and are just as perfeet, although not so abundant, as any produced in allied forms, such as Phytophthora phascoli.

Although the resting-spores or oöspores of this fungus have been produced in artificial cultures, it must not be inferred that they are also freely produced in nature, for it o.ly shows that the ancastors of this fungus possessed the power of sexual reproduction. In fact, Clinton recognises that the discovery is more of scientific than of practical interest, for he conchudes as follows:- "As the potato blight, so far as is known in nature, carries over from one season to another only through the vegetative mycelium in the tubers, it may be that continued asexual propagation of the fungus in this manner has also resulted in its loss of sexual vigour, especially of the antheridia." 


\section{AUATRALIAN LITERATURE.}

A.

1. Alrex, W. J.-Spraying Experiments at West Maitland for the Presention of Potato Blight. Agr. Gaz.. X.S.W., XX1., p. 571.1910.

2. —— Irish Blight and the Weathe:. Ibid. XXII., p. 31t. 1911.

B.

1. Bichexo, J. E.- On the Potato as an Article of National Dhiet, and the Potato Disease in eomnexion with Distress in Ireland. Proc. Roy. Soc., Van Diemen's Land. I.. p. 187.1851.

l. The Potato. Ibicl. XX., p. 696. I!ng.

2. Burler, E. D),-Potato Blight. Agr. Gaz., X.S. Y., XXII, p. 409. 1911.

(

1. Chmerox, S. S.-Discases of Farm Animals - Potato Poisoning. Journ. Agr., Vic.. VII., p. 109. 1909.

1. Chenry, T. - Tiz Victorian Potato Industry. Ibid. VII, 1, 593.1909.

1. Совв, Dr,-Diseased Potrtoes. Agr. Gaz., N.S.W., I., p. 119.1890.

2. - - The Potato Blight-Murrain or Rot. Ibit. II., p. 619. 1891.

3. - Remely for Potato beab. Tbid. XIY., P. 7:9. 1895.

4. -... Diseases of the Potato-Wet Roi-Scab. Ibicl. VIII., p. 222. 1697.

5. —— Gall Worm. Ibitl. VIII., 1) 235. 1897.

6. - Potato Diseases. Ibid. WII., 1. 276. T897.

7. - Wet Rot in Potatoes. Ibill. XII., p. 878. igin.

8. —— Root Gall. Ibicl. XII., p. 1041.1991.

9. - - Leaf Curl of Potatoes. Ibicl. XIV., p. 978. 1903.

10. - Disease in Seed Potatoes. Hid. XIV. p. Ss. 1903.

1. Cosxon, J. M. B.-Dodeter Infested Potato Plants. Journ. Agr., Yie. Mil. 1. 312. 1909 .

E.

1. Eowards, J. R.-Potato Seab - Cormesive Sublimaic for Potato Sicab. Arr. Ciaz. N.S.W. X., 1. 8+1. 1899 .

F.

1. Frexch, C.-Potato Hoth. Destructive Insocts of Victoria, p. 147. Part II. 1893.

2. T_L The Potato Moth (Lita solanella Boisd.). Jouru. Agr., Vie., IV., p. 577. 1906.

1. Froggat, W. W.-Catorpillar Plagnes, with an secomnt of the Potato Pests at Windsor. Agr. Gaz., N.S.W., XII., p. 237. 1901.

2. _- - The Farmer's Garden and its Enemies. Ibicl. XVI., p. 1034. J90.5.

G.

1. Gatlard, L. Spraying for Irish Blight. Agr. Gaz., N.S.W., XXII., p. 84. 1911.

1. Gexvys, R. H.-Potato Diseases. Itid. XIX., p. 196. 1908.

1. Grasbr, W. C. Summer Temperatures of the Soil. Natural History and Seienee Society of West Australia. Published in "West Anstralian," 17th Fobruary. 1911.

1. Grecorr, J. G.-Potato Scab. Journ. Agr., Yic.. III., p. 671. I909. 
II.

1. Haywool, A. 11.-Potato Spraying at the Grafton Experiment Farm. Agr. Gaz., N.S.W., XXI.. p. (63. 1910.

I. Hedvis, R.-Report on an Invistigation into the Potato Discases prevalent in the (Clarone Rivor District. 1bid. VI, p. 316. 1895̃.

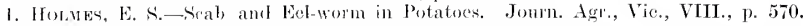
$1911 \%$.

1. Huxter, A. T.- Notes on Irish or Lato Blight of the Potato. Agr. Gaz., N.S.W., XXI., p. 579. 1910.

J.

1. Jollvon, T. IT.-Potato Dineases. Ann. Ropt. Govt. Bureau Microbiology, p. 57. 1909.

2. —— Notes on Some PIant Diseases. Agr. Gaz, N.S.W., XXI., p. 563.1910.

3. ___ Notes on a Fungus foumd Destroying Potatoes. Ibit. XXI., p. 699. 1910.

K.

1. Kusblewrers, (4. F. Sinulight as a Possible Remedy for Irish Blight. Agr. Gaz, N.S.W., XXT., p. 9.1. 1910.

L.

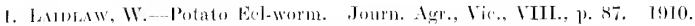

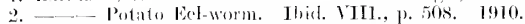

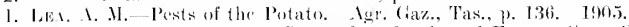

2. - Insente and Fungus Pests of Oreharde and Farm. Council Agr., Tas. 1908.

3. - Potato Diseases. Igr. (i:tz... Thas., XVII., p. 155. 1909.

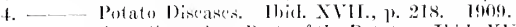

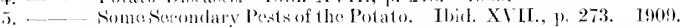

(i) —— Brown Rust, Brown Rot, Brown Spot, or Dry Rot of the Potato. Agr. and

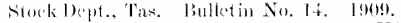

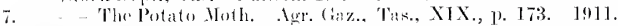

s. - Irish Blight. Igr. liaz., T:s., N1X.. p. 357 . 1911.

I. Lexiox, W.-Formalin for Potato Neab. Agr. Caz., N.s.W., XXII, p. 262.1911.

.I.

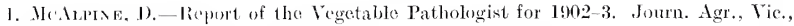
II., p. 2.5. 1903.

2. - - Warly Blight of the Potato. Itid. p. 46 . 190.t.

3. - Potato Expriments at Bunyip. Ibid. III., p. 440.1905.

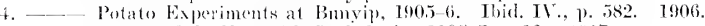

5. _- Report of the Vengetable Pathologist, 190.7 7, p. 32. 1907.

(i. - L Lish Potato Blight Leaflet, No. 3. 1909.

7. —— Potato Btight and its Treatment. Bulletin No. 27. 1909.

s. - Lrish Potato Blight and its Treatment. Journ. Agr., Vie., VII., p. 698. 1909.

9. - - I'ish Potato Blight. Wall sheet. 1910.

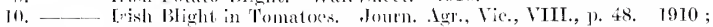

11. —- Lrish Blight in Tomatos. Journ. Agr.. S.A., XIII, p. 5056. 1910.

12. —— Some points of practical impontance in commexion with the Life History

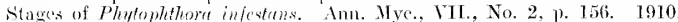

13. - Tosting Potato Varieties for Irish Blight. Journ. Agr', Vic, VIII., p. 358. $1: 10$.

14. _ - Report of the Vegetable Pathologist for 1909-10, p. 51. 1910.

15. - - Potatoes and Tontates on the same Plant. Journ. Agr., Vie, VIII., p. 205. 1910.

16. - - Prevention of Potate Blight by Spraying. Ibid. IX., p. I26. 1911.

17. - - Spraying for Irish Blight. Ilrid. IX., ]. 378. 1911.

18. —— T'omatoes and Irish Blight. Ibid. IX., p. 379. 1911.

I. Mustidye, S. R.-Experience with the Irish Blight-Now Seed and Now Ground alvorated. Agr. Caz. N.S.W., XXII., p. 519.1911.

1. Mrssos, ('. T.-A Warning to Potato Growers. Ibid. XVI., p. 423.1905.

2. - Pota1o D)iseances. Ibid., XVI., p. 591. 1905.

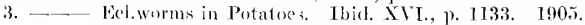

1. — and Marks, (1. - Wot Rot of Potato sin the Hawkesbury District. Ibid. XVI., p. $186 \% .190 \%$. 
0.

1. Otriff, A.-Entomological Notes. Agr. Gaz., N.S.W., II., p. 158.1901.

2. ——— Entomological Notes. Tbid. III., p. 701. 1902.

P.

1. Pratt, E. C.-The Control of Irish BIight in Potatoes. Agr. Gaz. Tas., XIX., p. 211.1911.

Q.

I. Quins, G.-Potato Ring or Brown Rot. Jourm. Agr., S.A., XI., p. 1043.1908.

2. - - The Irish Potato Blight. Ibid. XIII., p. 97. 1909.

3. —— Potato Blight. Ibid. XIII., j. 189.1909.

4. ——- Irish Blight. Ibid. XIII., p. 315. 1909.

S.

1. Sexmovr, G.-A Few Points on the Care and Preparation of Seed Potatoes. Journ. Agr., Vic., III., p. 640. 1905.

2. —— Selestion of Seed Potatoes. Ibid. IV., p. 236. 1906.

3. —- Potato Experimental Fields, J305-6. Ibid. IV., ]. 469. 1906.

4. - - Seod Potato House. Ibid. V., p. 228. 1907.

5. —— Potato Expe simental Fields. Ibid. V., pp. 547 and 649. 1907.

6. - _ Results attainol from Imported Varieties of Potatoes. Ibid. VI., 1. 292. 1908.

7. -_- Potato Exposimental Fields, 1908-9. Ibid. VII., p. 728. 1909.

8. —- Expe iments with Potato Diseases, 1909-10. Ibid. VIII., p. 360. 1910.

9. —— Potato Experimental Fields, 1909-10. Ibid. VIII., p. 711. 1910.

10. —— Potato Exporimeats at Cheltenham, 1910-11. Ibid. IX., p. 171. 1911.

1. Sumarers, W. L.-Spraying Potatoo,s for Ir ish Blight. Jonrn. Agr., S.A., XIII., p. 10is, 1909.

\section{T.}

1. Troswerl, F., and Jomsson, T. H.-The Potato Bliglit. Agr. Gaz. N.S.W., XX., p. 809.1309.

2. - - On certain Fungoid Diseases of Potatoes (including Irish Blight). Ibid. XX., p. 998.1909

1. Tryox, H.-Report on Inseet and Fungus Pests. No. 1. Dept. Agr., Queentanel. 1889.

2. —— Potato Discases. Journ. Agr., Qnsld., V., p. 57. 1899.

3. - - Potatoes-Ins, yestion and Treatment. Ibid. XXIV., p. 145. 1910.

4. ——— Potato Diseases. Ann. Rept. Dept. Agr. Qnsld., p. 88. 1909-10.

5. —_. The Potato Disoase. Journ Agr., Qnsid., XXIII, p. 118. 1909.

\section{U.}

1. Ulbrick, F. W.-Potato Culturo-Scab. Agr. Gaz. Tas., XVIII., ). 160.1910.

V.

1. Vhlder, G.-Potato Scab-Trials of Specifies. Agr. Gaz., N.S.W., XII., p. 969. 1901. 
PLATE I.

Fig.

POTATO BLIGHT.

1. Snowflake viriety of potato with Irish Blight fungus on the surfare in the form of numecous white delinate patehes towards stalk end. 
Phate 1.

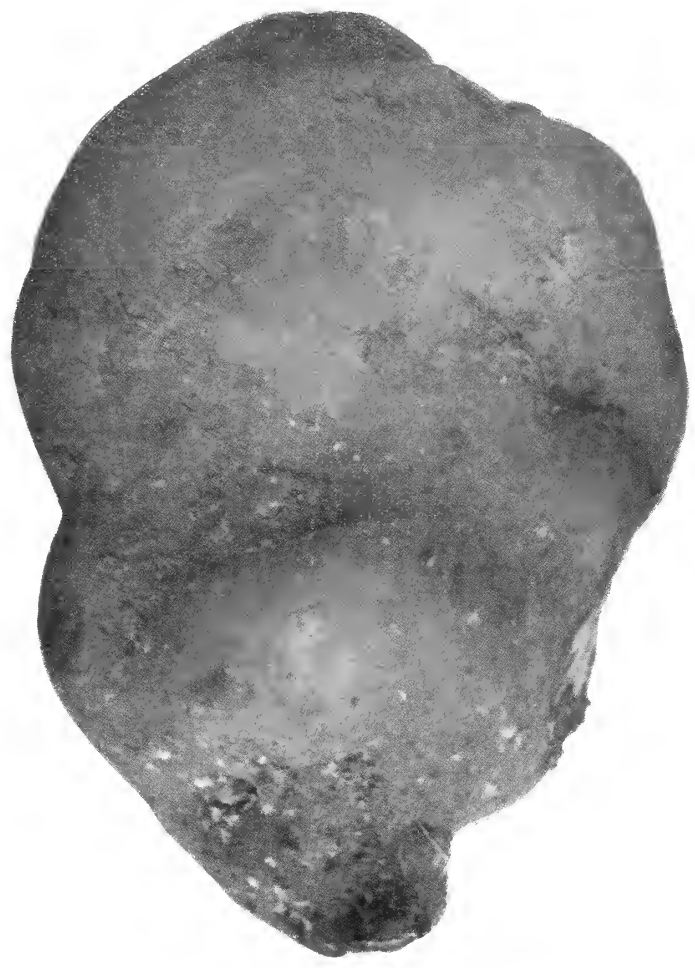

SNOWFLAKE WITH IRISH BLIGHT 



\section{PIAT' II.}

live.

\section{POTATO BIAL:HT:}

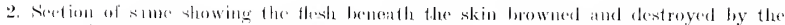

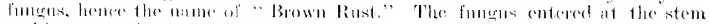
ancl is progerescing towatrio the crown. 


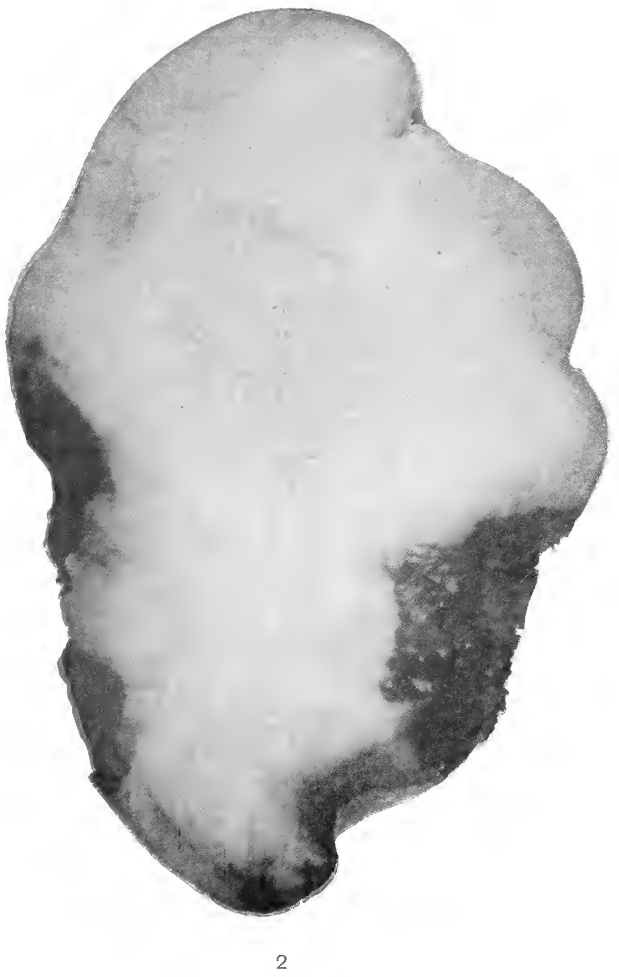

INTERNAL VIEW OF SNOWFLAKE WITH IRISH BLIGHT 


PLITE III.

POTATO BLIGHT.

Fig.

3. Upjer surface of leaf showing effects of Blight.

4. Potite with dense white monld of lrish Blight fungus. Shortly afterwards it was overrum with a luxuriant white mould of Fusarium. 


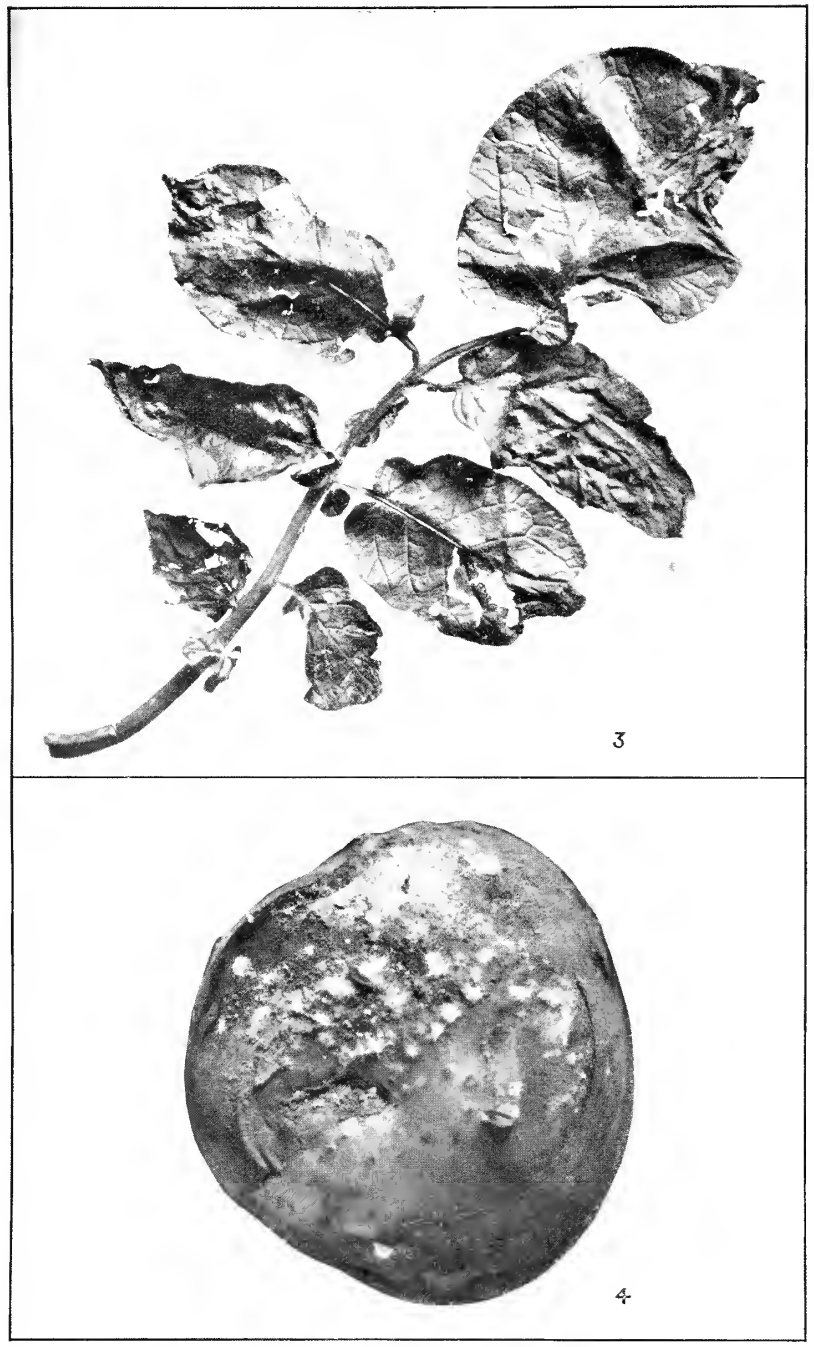

C. C. Brittlebank, Phot.

DISEASED LEAF-UPPER SURFACE POTATO WITH DENSE MOULD OF BLIGHT 



\section{PLATE IV.}

\section{POTATO BLIGHT.}

Fig.

5. Sxation throwg a disnsad leaf, showing myeelium in the tissues, and fructification on lower surfice, with two fertile hyphæ projecting through a stoma at
st. . .
..
.
.
.
.. $\times 150$

6. Spuwn or mycelium of fungus from the cut surface of a diseased potato . $\times 300$

7. Hyphæ among the cells of the potito spread out by pressure $\ldots \quad \ldots \times 150$

8. Simall piece of disansel pot ito showing the spawn of the fungus, surrounding and discolouring the cells cont ining starch $\quad \ldots \quad \ldots \quad \ldots \quad \ldots \quad \times 150$

9. Fientification with sporangia or spore-cases at different st iges of growth.. $\times 300$ 
Plate: IV.

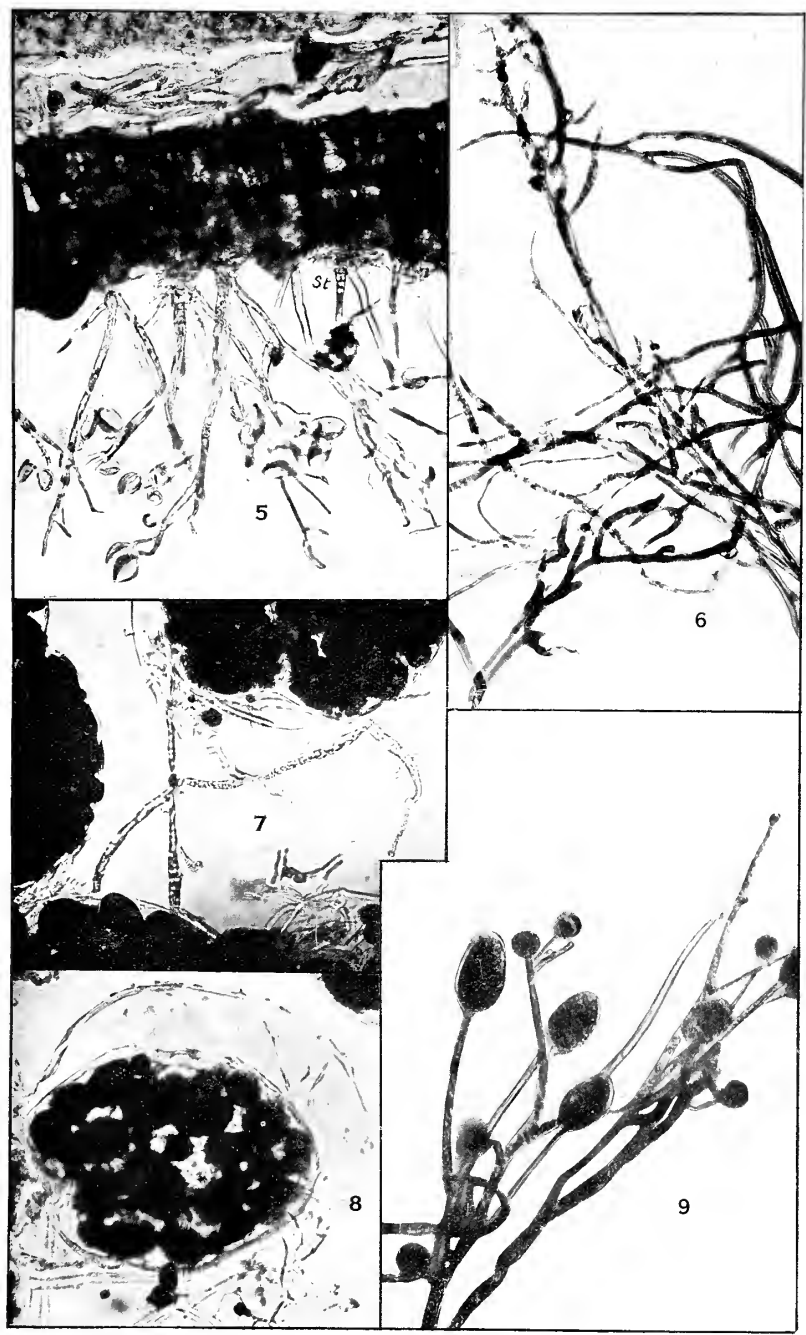

C. C. Brittlebank, Phot.

SECTION OF DISEASED LEAF, MYCELIUM AND FRUCTIFICATION 


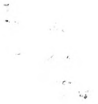





\section{PLA'TE Y.}

Fig.

\section{POTATO BLGGH'.}

10. Fructitication with sporangia at tuched, showiug four branches from maiu stem $\times 150$

11. Fructification shown arising from mycelium at base .. .. . $\times 300$

12. Frnctifiction, showing mode of brunching, with brenches irregularly swollen at intertals where sporangia were detached. As many as eight swellings have

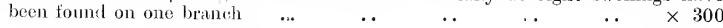

13. Spormaium with contents dividing, and nnother from which the swarm-spores have escaped, showing one at opening .. $\quad . .6 \quad \ldots \quad \ldots \times 30$

14. Cironp of sprorangia with the contents breaking up $\ldots \quad \ldots \quad \ldots \quad \ldots \quad \times 30$ 
Puate $Y$.

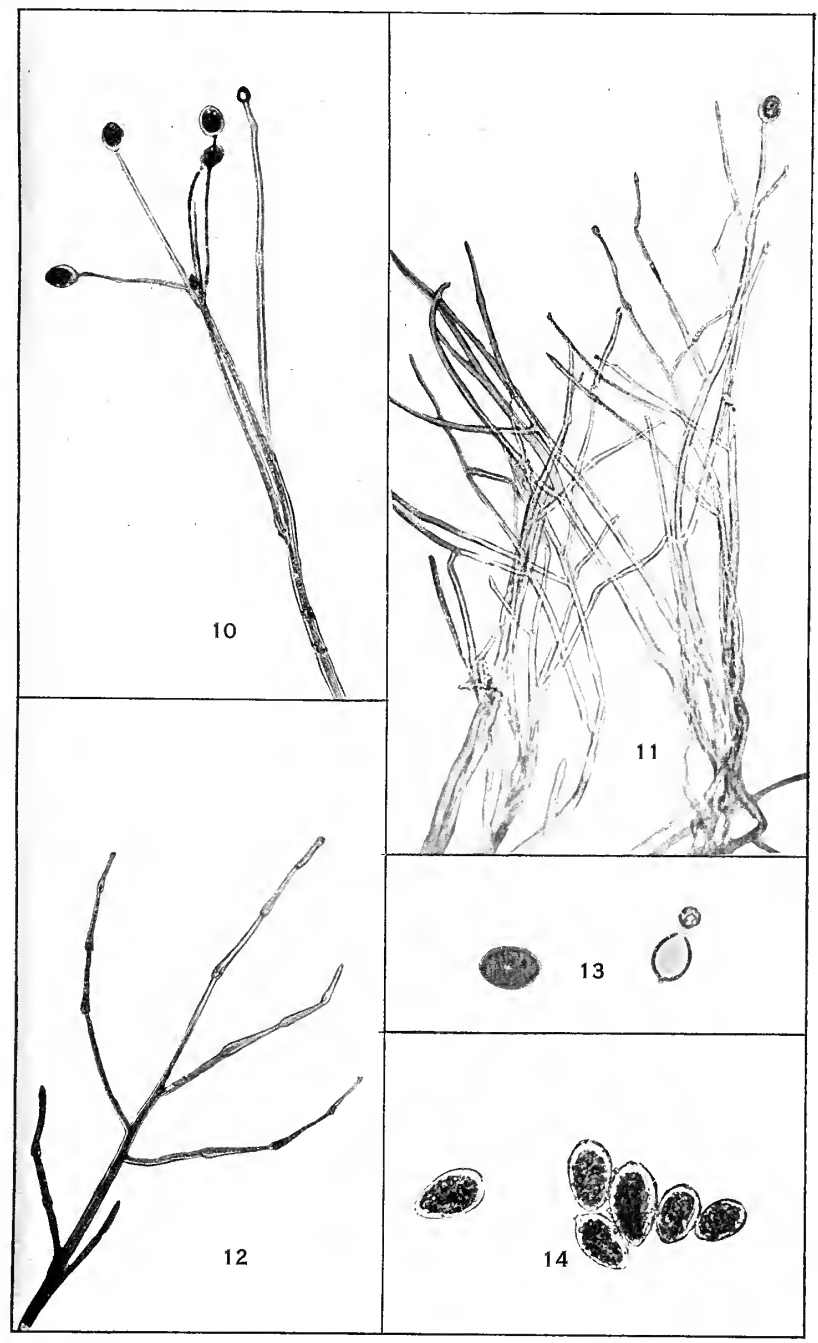

C. C. Brittlebank, Phot.

FRUCTIFICATION AND SPORANGIA

$\times 150$ and 300 WITH ESCAPING ZOOSPORE 


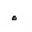




\section{PLATE VT.}

Fig.

\section{POTATO BLIGHT.}

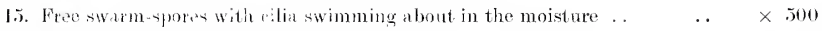

16. Swrm-spores com: to rest, with rilia dropped and spore putting forth germ-

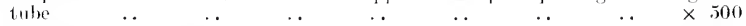

17. ('ondia directly germinating $-A$, with two germ-tubes unbranched; $B$. with

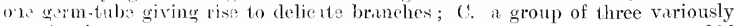

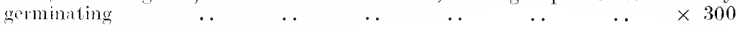

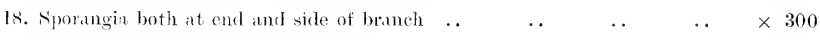

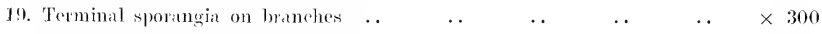

Gondium sprouting and forming a soondary conidium at its free end $\ldots \quad \times 500$ 
Plate VI.

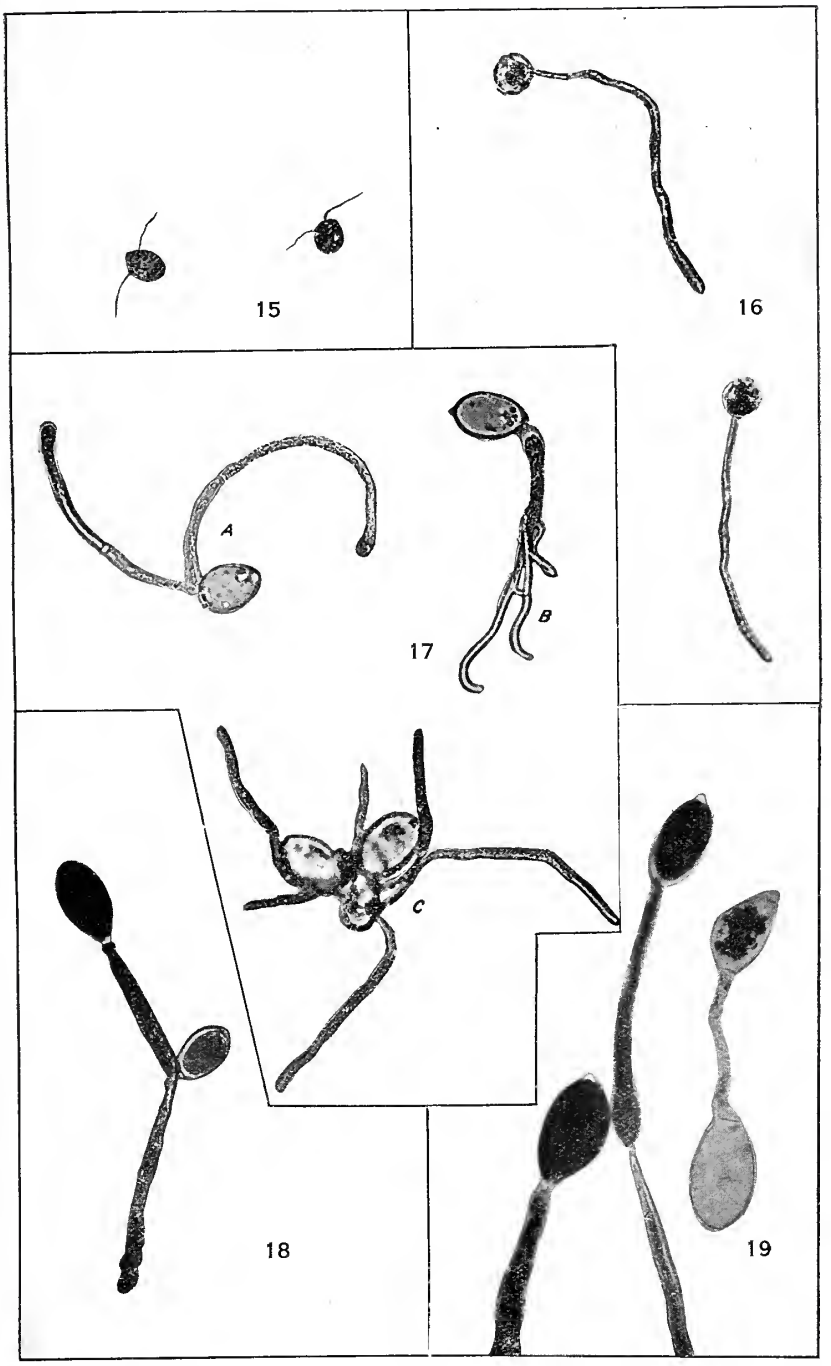

C. C. Brittlebank, Phot.

$\times 300$ and 500

ZOOSPORES AND CONIDIA GERMINATING, TOGETHER WITH LATERAL AND TERMINAL SPORANGIA 
. 
PLATE VII.

Figs.

\section{BARLY BLIEHT}

20. Young leaflets of potato affected by the Early Blight, showing the tormation of small discoloured spots. which sometimes fall ont and leave at hole.

21. Wature leaf of potato, showing large dry sprots due to the growth of the fungus. 


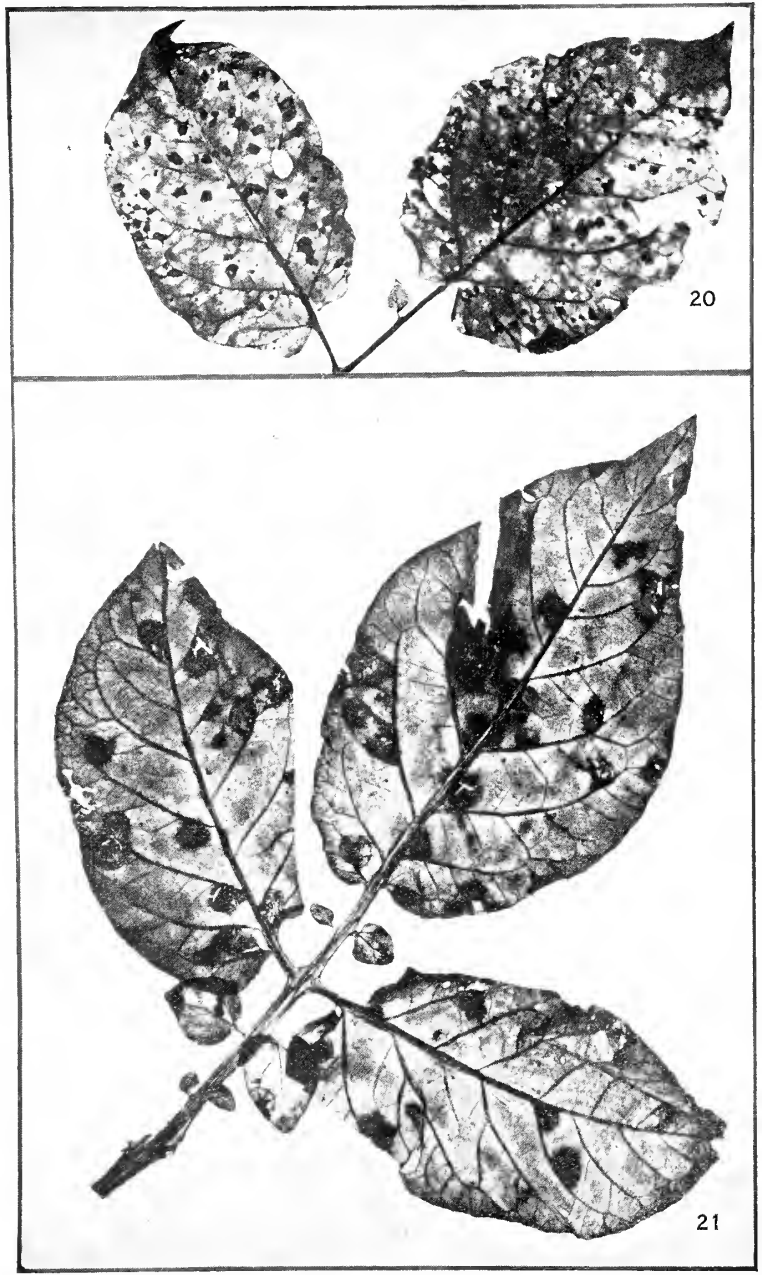

G. II. Robinson, Phot.

EARLY BLIGHT OF POTATO

Nat. Size YOUNG AND MATURE LEAVES AFFECTED 



\section{PLATE VIII.}

Fig.

\section{EARLY BLIGHT.}

22. Conidia-bearers and conidin of the fungus growing on the leaf $\ldots \quad \ldots \quad \times 100$

$23,24,25$. ('onidia with one, two, and three beaks $\quad . . \quad \ldots \quad \ldots \quad \ldots \quad \times 250$

26. Conidium with one beak, npon which a cup-shaped conidia-bearer has been formed, the conidium shown in Fig. 23 having fallen from it $\ldots \quad \ldots \times 250$

27. Chain of two condia. In the larger the single terminal beak has become modified so as to serve as a conidia-bearer, being terminated by the characteristic cup$\begin{array}{llllllll}\text { shaped apex } & \ldots & \ldots & \ldots & \ldots & \ldots & \ldots & \times 250\end{array}$

23. Conidium showing the mo lific ttion of the single terminal beak into a conidia-bearer

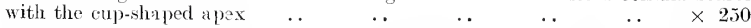

29. Conidium germinnting in a decoction of potato-leaf, showing the formation of myedium, in turn giving rise to a conidia-bearer and eonidium $\ldots \times \mathbf{2 5 0}$

30. Conidia grminating in a decoction of potato-leaf, one of them producing two conidiabearers, exch bearing a conidium with two beaks..$\quad \ldots$ 人 $\mathbf{2 5 0}$

31. Conidium germinating in potato-leaf deeoction, a secondary conidium being formed at the apex of the conidia-bearer arising from the terminal benk .. $\times 25$ 


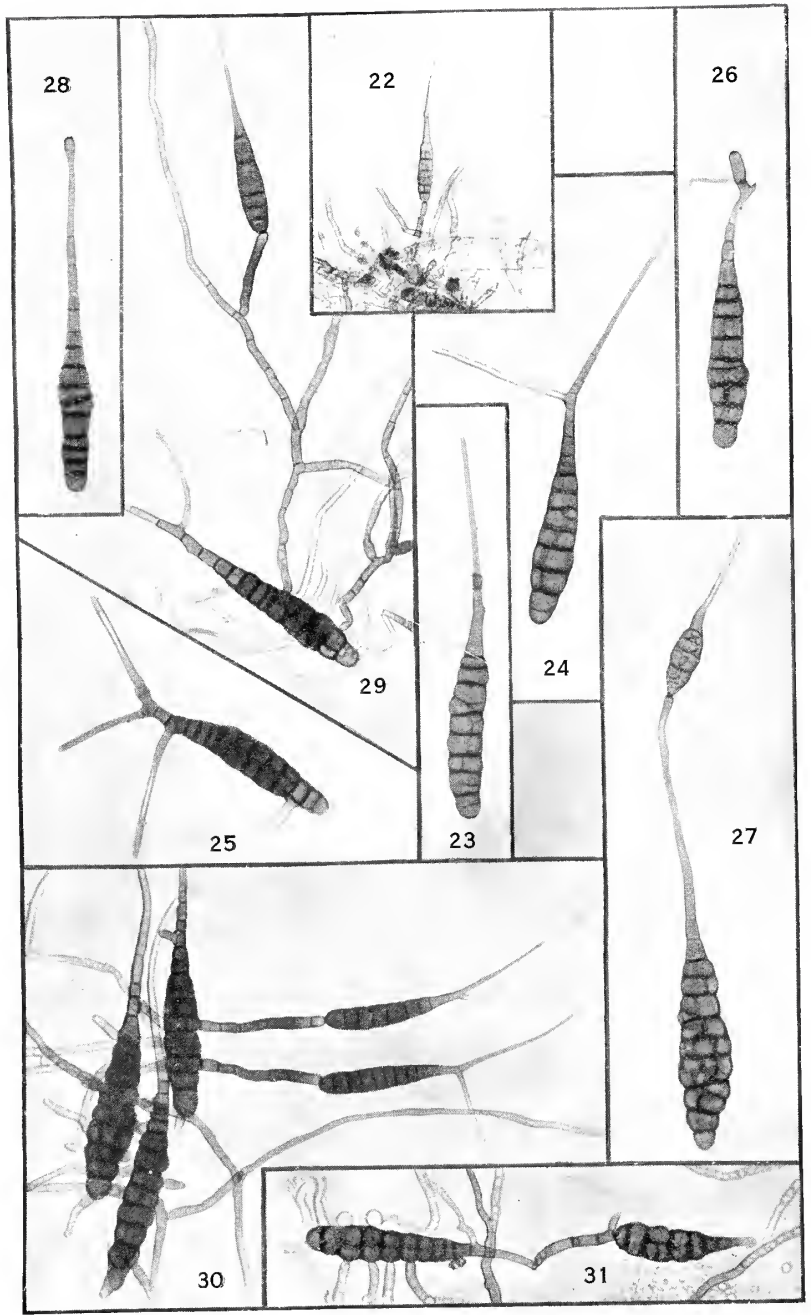

G. H. Robinson, Phot, 



\section{PLATE IX.}

Fig.

\section{RHIZOCTONIA ROT.}

32. Sterotit on two potatoes from Tasm mia, generally distributed over the surface, and of various sizes.

33. Sclerotia on potato from South Australia, sometimes confluent. 
PJ.ATf IX,

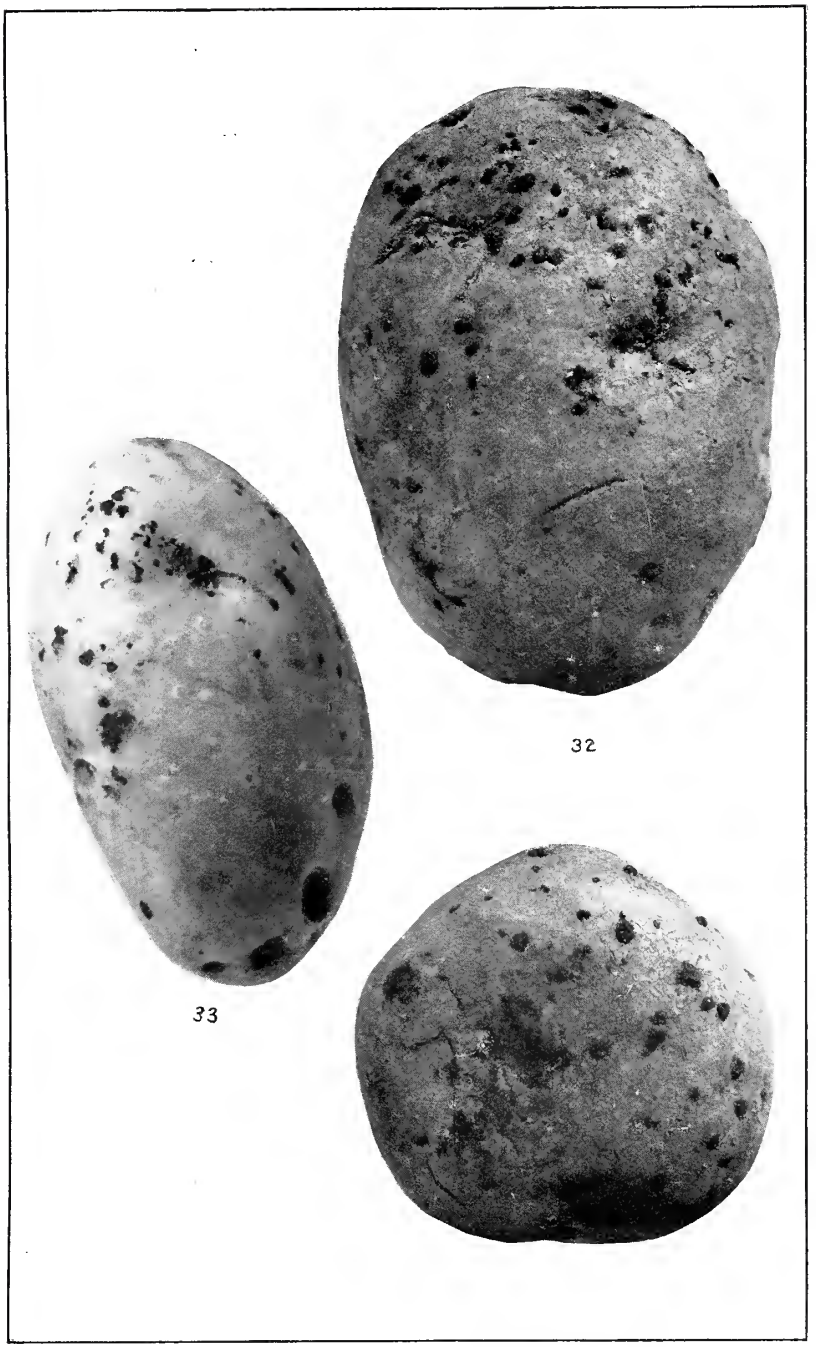

Nat. Size

RHIZOCTONIA, SHOWING SCLEROTIA 



\section{PLATE X.}

Fig.

\section{RHIZOCTONIA ROT.}

34. Section of Tasmanian potato, showing what looks like "Brown Rust," due to Rhizoctonia. The filaments of the fungus were jointed and no potato blight developed after keeping moist for a considerable time. 


$$
0
$$






\section{PLATE XI.}

\section{RHIZOCTONIA ROT.}

Fig.

35. Three young potato plants, dying from effects of Rhizoctonia. 
Piate XI.

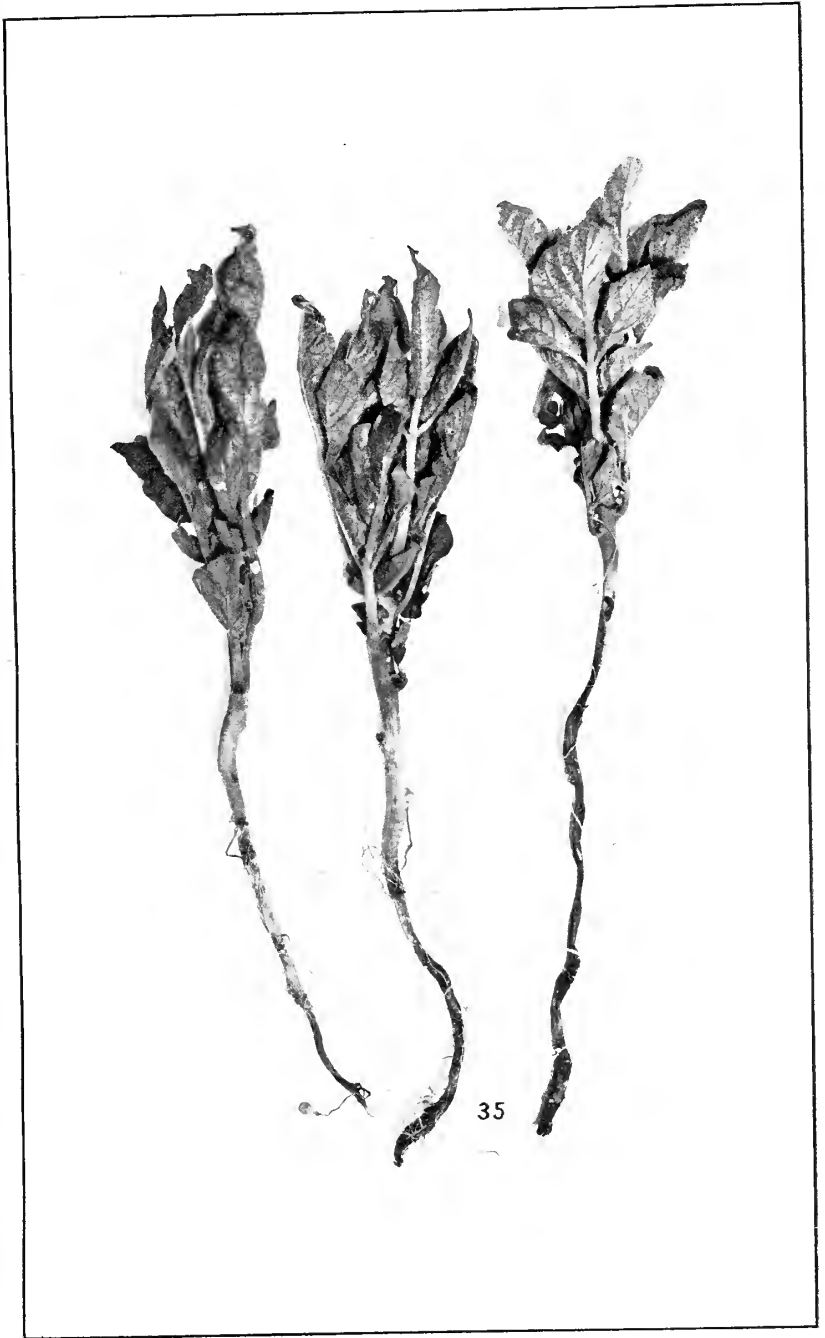

c. C. Rrittlebank, Phot. YOUNG POTATO PLANTS DYING FROM EFFECTS OF RHIZOCTONIA 


36. Section through sclerotium on surface of potato, showing the tangled mass of jointed hyphæ composing it .. $\quad$. $\quad \ldots \quad \times 170$

37. Section of sclerotium in flesh of potato, extending $\frac{1}{2}$ inch benenth surface. It is sometimes stated that the sclerotium is always superficial $\quad . \quad \times 170$

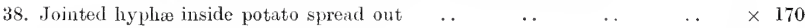

39. Hyphe immediately beneath corky cells of skin of potato, as seen from the sur$\begin{array}{lllllllll}\text { fare } & . & \ldots & \ldots & \ldots & \ldots & \ldots & \ldots & \times 170\end{array}$

40. Hyphre ramifying among starch-cells of potikto $\quad \ldots \quad \ldots \quad \ldots \quad \ldots \quad \ldots \quad \times 500$ 


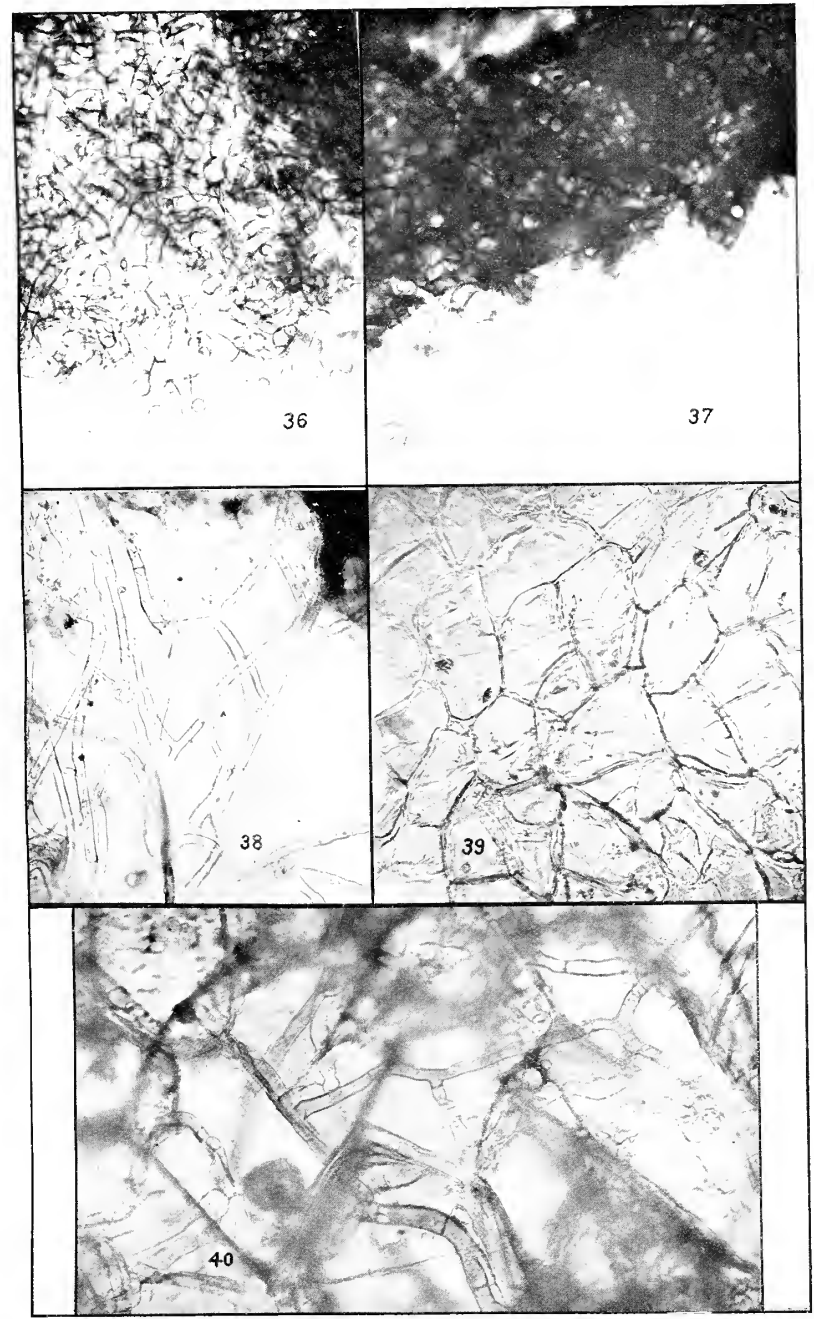

C. C. Britulebank, Phot. 


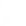





\section{PLATE XIII.}

\section{RHIZOCTONIA ROT.}

Fig.

41. Hyphæ on $\begin{array}{llllllllll}\operatorname{root} & \ldots & \ldots & \ldots & \ldots & \ldots & \ldots & \ldots & \times 170\end{array}$

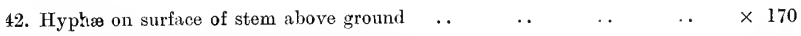

43. Conilial stage, showing oval terminal cells, one of which bears two young

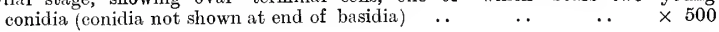




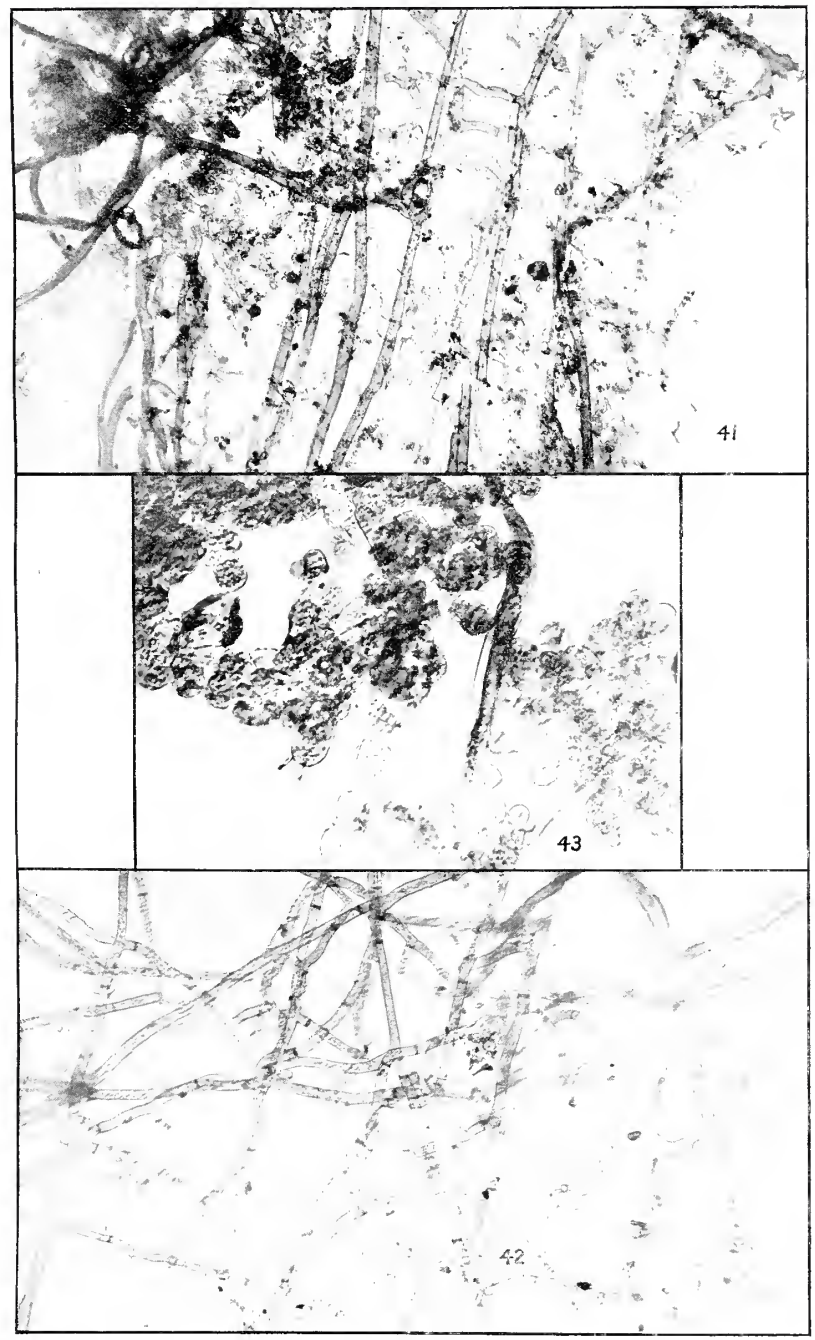

C. C. Brittlebank, Phot.

HYPHAE ON STEM AND ROOTS CONIDIAL STAGE 




\section{PLATE XIV.}

\section{POTATO SCAB.}

Fig.

14. Cross-section of healthy skin of potato showing lenticels or breathing pores (after $\begin{array}{llllllll}\text { Soraner) } & \ldots & \ldots & \ldots & \ldots & \ldots & \ldots & \ldots\end{array}$

$k$. corky cells of skin; st. starch-containing cells beneath skin; $a$. lenticel just beginning to form; $f$. lenticel formed and filled with loose mealy cells.

45. Potato with "blister" due to Eel-worm, some of them broken and forming scab-like depressions on the surface. 


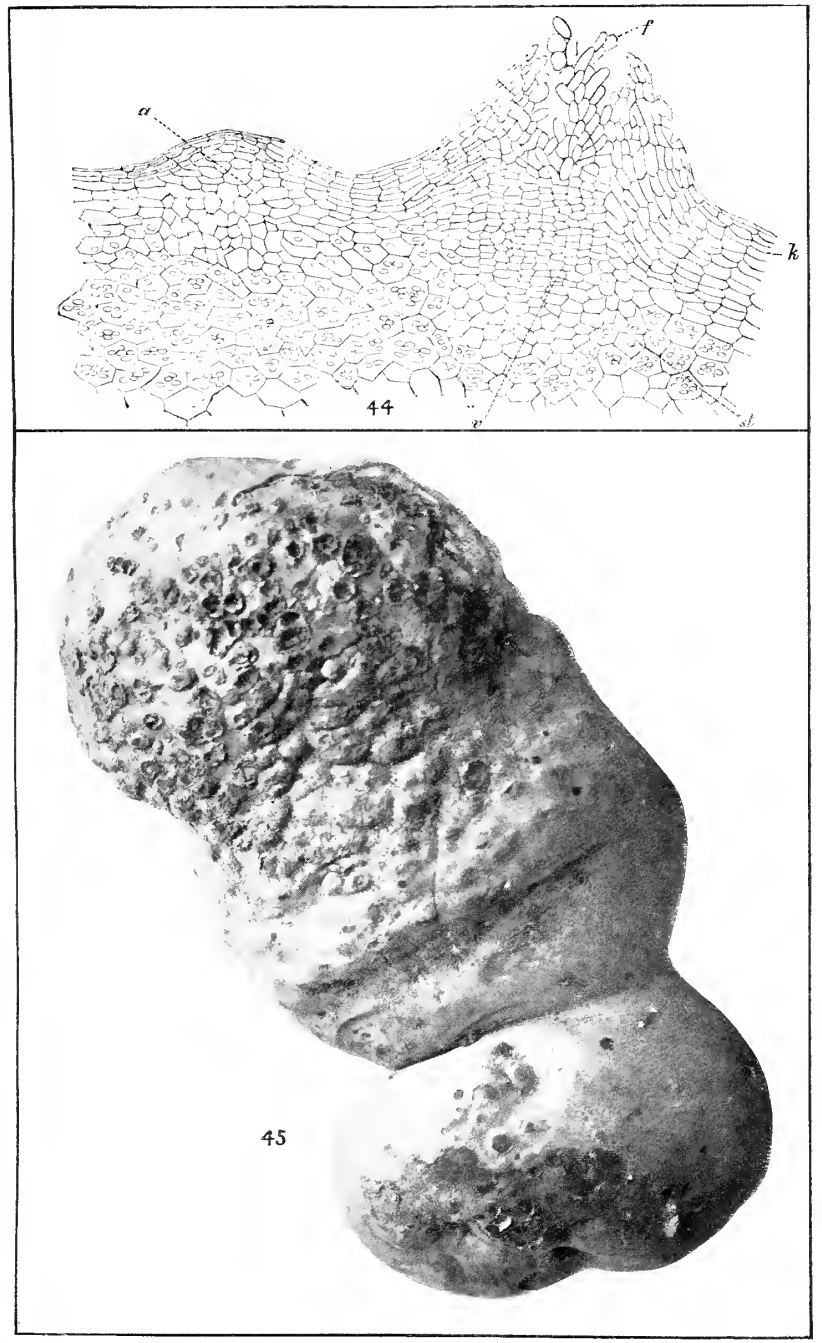






\section{PLATE XV.}

Fig.

\section{POTATO SCAB.}

46. New Zealand Pink Eye, showing blisters broken and the tubers variously affected

. $\quad$. $\quad$.. $\quad$.. $\quad$ Reduced

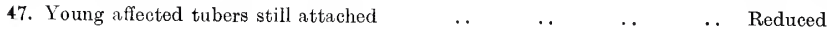




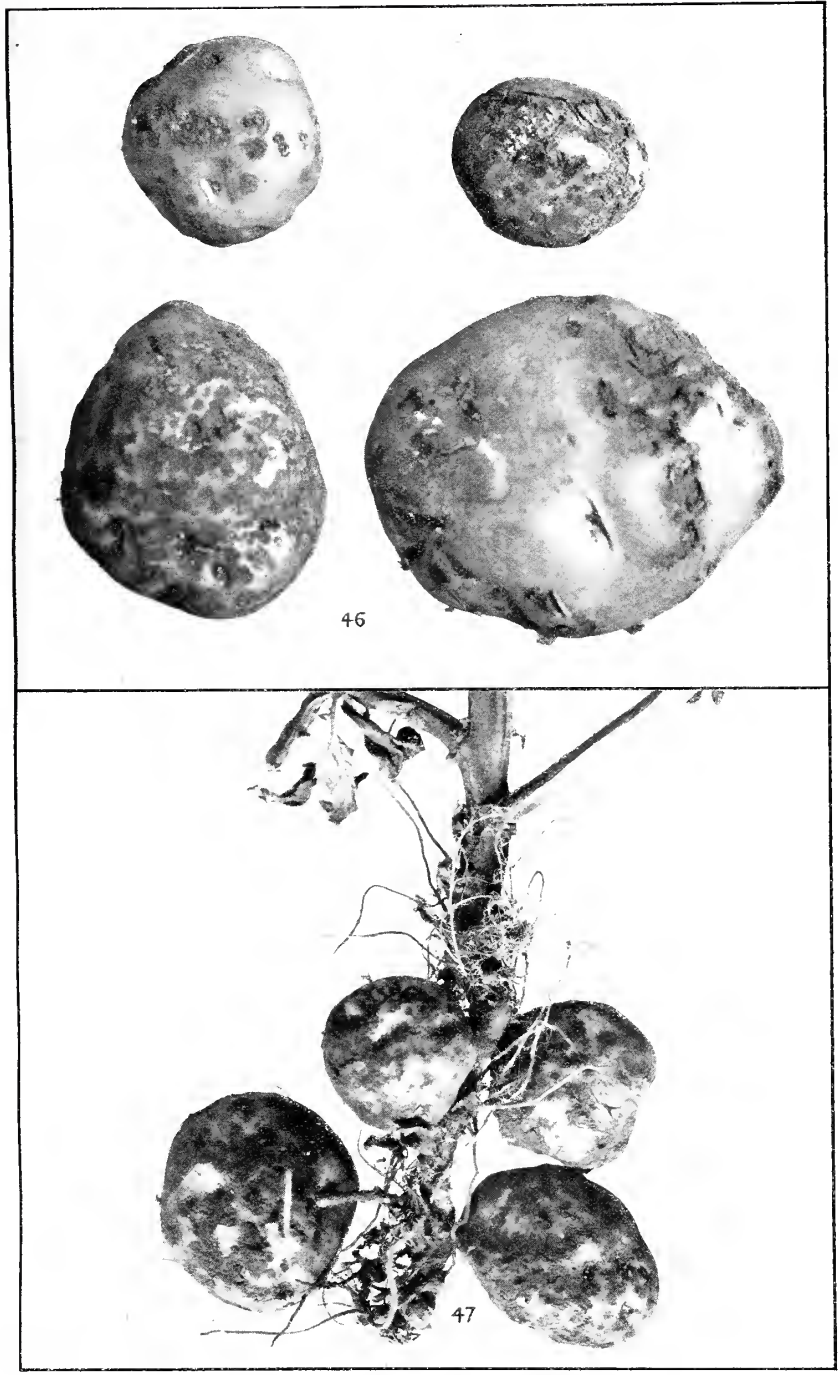

C. C. Brittlebank, Thot. 




\section{PLATE XVT.}

\section{PO'TATO SCAB.}

Fig.

18. Potato with blisters-broken and unbroken.

49. Potato with most of the surface covered by broken blisters.

.0. Potito with broken blisters in isolated patches and presenting a "seabby "appearance.

.31. Carman No. 1 potato with broken blisters run together, taken from sample which was treated at Bunyip in 1905 and produced practically a clean crop, while the untreated were largely "scabby." as shown in Plate XVII. 


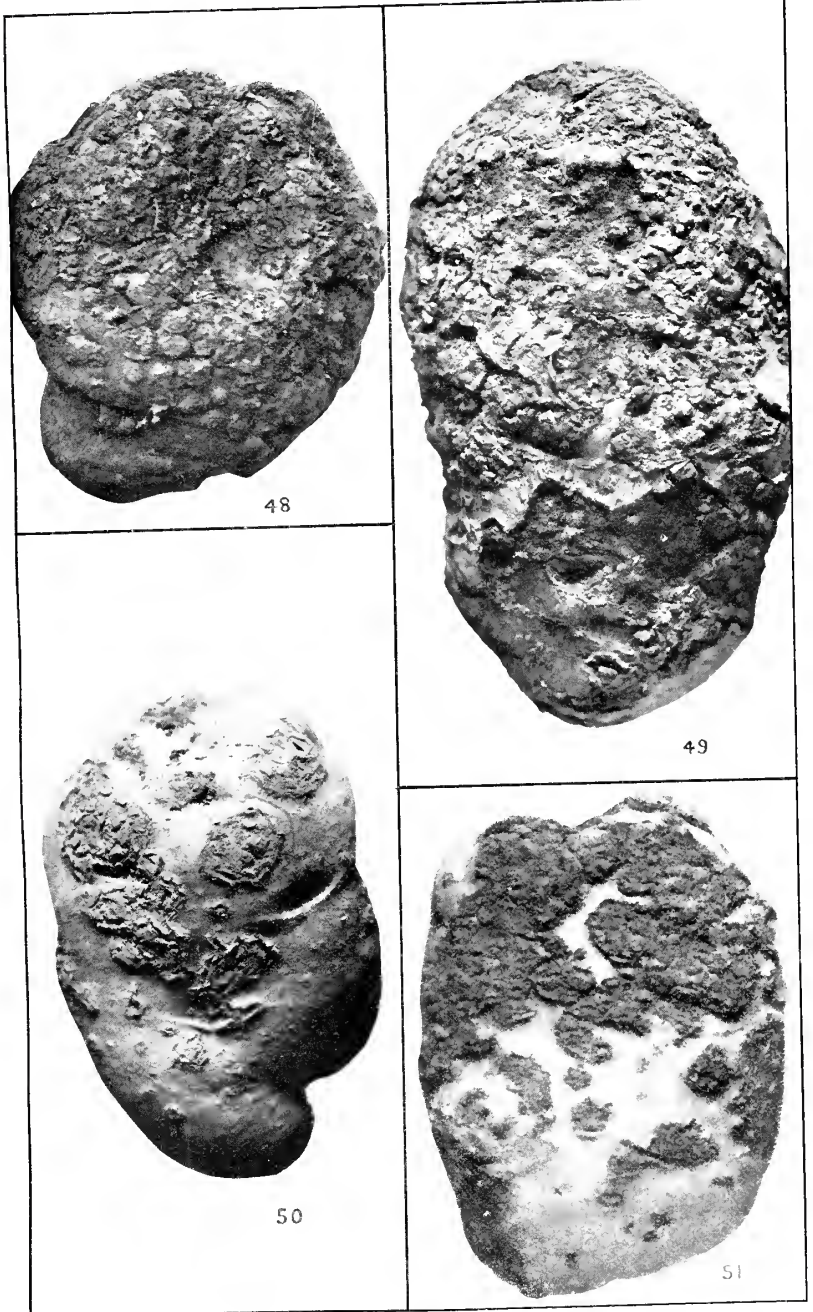

C. C. Brittlebank, Phot.

BLISTERS-BROKEN, UNBROKEN, AND RUN TOGETHER 
. 

PLATE XVII.

\section{POTATO SCAB.}

Fig.

52. Produce of "scabby" seed untreated -a larger proportion scabbed than clean.

53. Produce of "scabby" seed treated with corrosive sublimate-all practically clean.

54. Produce of clean seed infected by contact with "scabby" seed and untreatedabout as many scabbed as clean. 


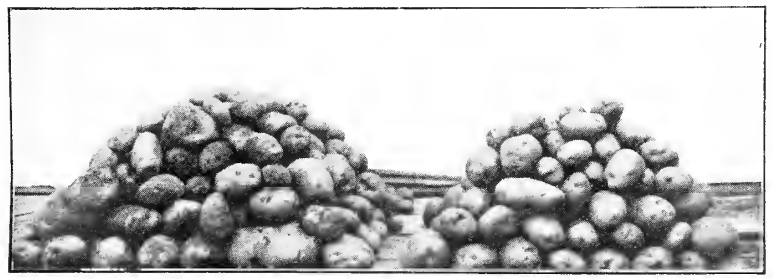

52

SCABBY SEED UNTREATED.

77 lbs. scabbed.

58 lbs clean.

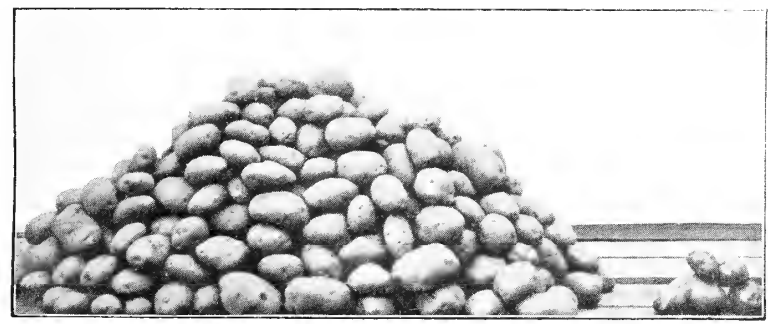

53

SCABBY SEED TREATED WITH CORROSIVE SUELIMATE. 195 Ibs. clean.

2 Ibs. scabbed.

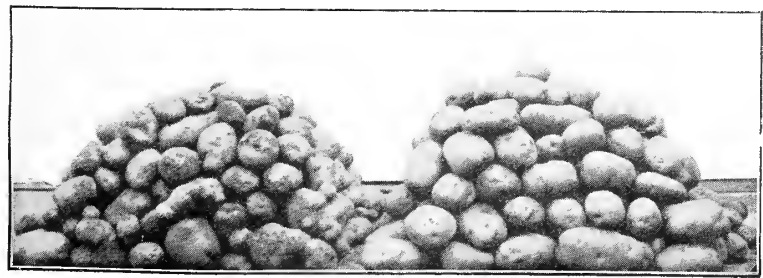

54

Reduced

CLEAN SEED INFECTED BY CONTACT-UNTREATED.

84 lbs. scabbed.

89 Ibs. clean. 



\section{PLATE XVIII.}

Fig.

\section{POTATO SCAB.}

55. Longitudinal sections of potatoes showing little round cysts beneath the skin and extending completely round-these are the female eel-worms distended with cggs.

56. Section of "scab" caused by eel-worm, showing layer of flat corky cells between the top or outside diseased and the immer healthy portion. The irritation caused by the eel-worm has brought about a development of cork beneath the broken

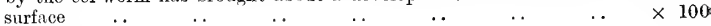

5.7. Potato with black warty excrescences at "eyes," associated with potato moth, and no fungus or eel-worm present

58. Black "scabs" run together due to Rhizoctonia. 


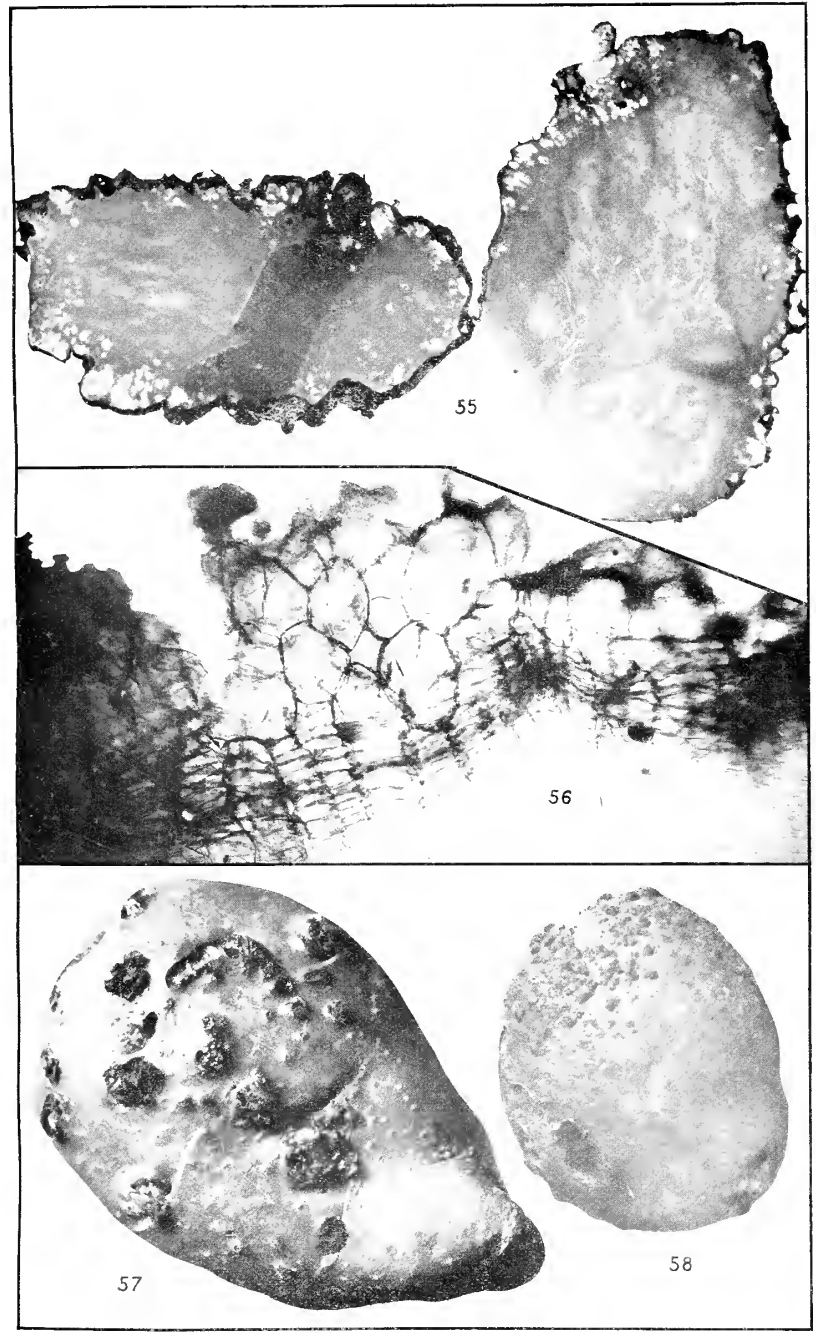

C. C. Brittlebank, Phot.

POTATOES WITH MOTH, EELWORM, 

. 


\section{PLATE XIX.}

Fig.

\section{POTATO SCAB.}

59. Portion of pot ito, showing small warty exerescences at the lenticels due to Rhizoctonia. 60. Saction of skin of sıms, showing filuments of Rhizoctonia penetrating the "flesh" of the potito

.

61. Another saction showing the same more clearly to the right $\times 100$ 


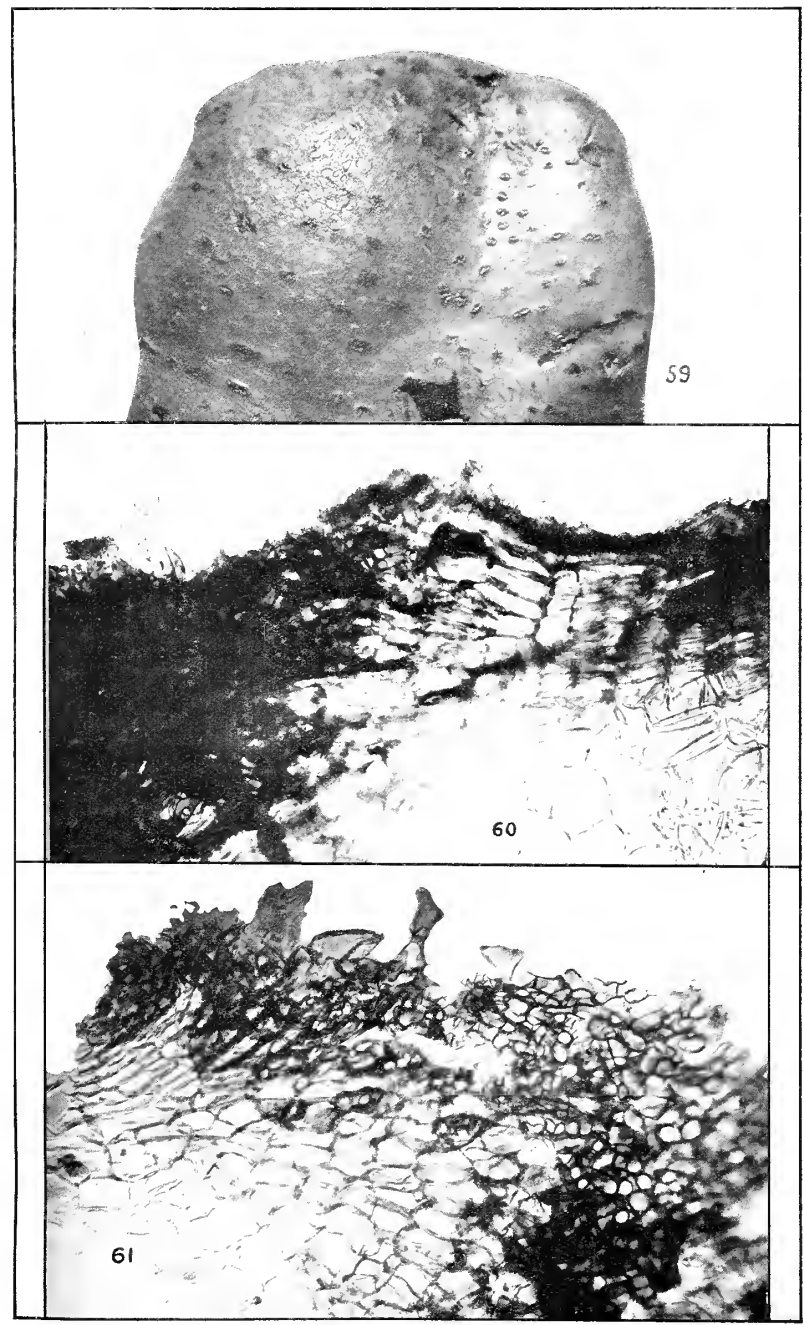

C. C. Brittlebank, Phot.

Nat. Size $\times 100$

MINUTE WARTS CAUSED BY RHIZOCTONIA AND SECTIONS OF SAME 


\section{.}




\section{PLATE XX.}

Fig.

$$
\text { POTATO SCAB. }
$$

62. View of potato plots at Burnley in connexion with Scab Experiments on 6th April, 1910 , showing the luxuriant growth of the erop planted 18th December, 1909, and the bird-proof enclosure in the back ground used for experimental purposes. 
PHTE XX.

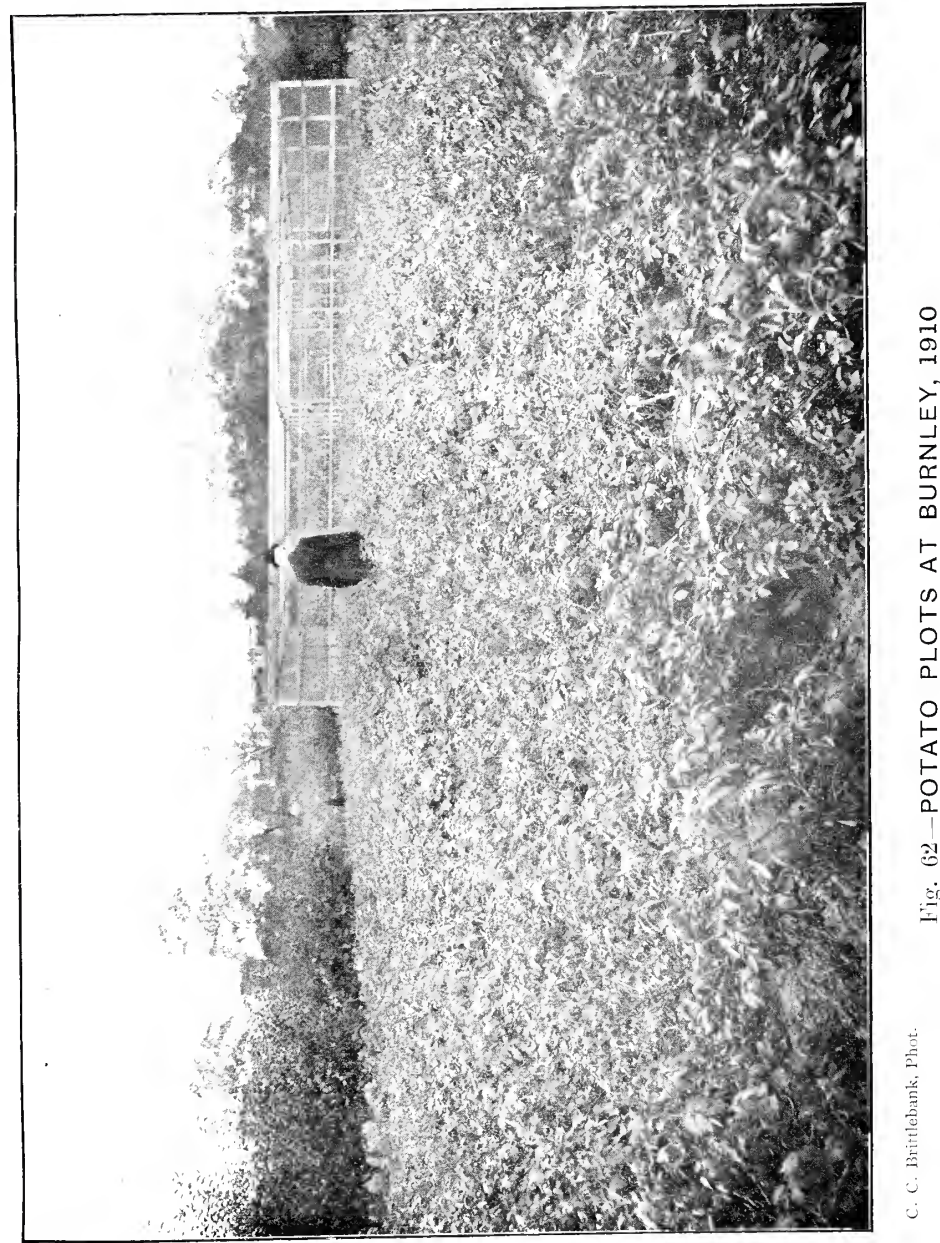






\section{PLATE XXI.}

(From Journal of the Board of Agriculture, January, 1909.)

Fig.

POTATO $\mathrm{SCAB}$.
63. Scab due to mechanieal injury.
64. Scab due to Oospora seabies, Thax.
6.5. Scab due to False Wireworm (Julus pulchellus, L.).
66. Scab due to Spongospora subterranea (Wallr.) Johnson. 


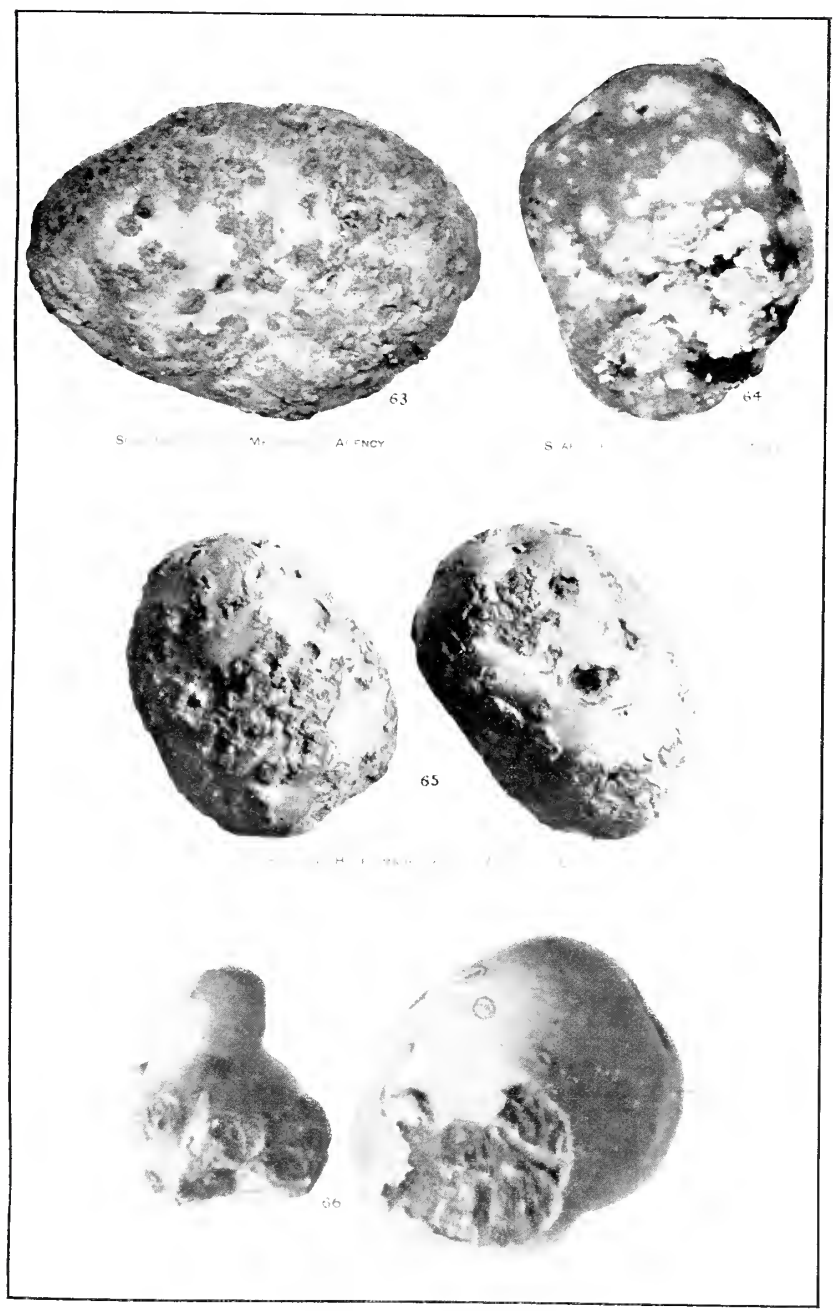






\section{PLATE XXII.}

(Fig. 67, 68, after Salmon; Fig. 69, after Clinton.)

Fig.

POTATO SCAB.

67. Potato still attached to underground stem, showing warty excrescences of "Black Scab."

68. Growing potato plant attacked above and below ground. At $\times$ is a diseased shoot above ground, showing the same disease.

69. Potatoes with Dry Scab or Seurf, forming slightly sunken areas of a dark-brown colour, with dot-like sclerotia or minute black specks. 


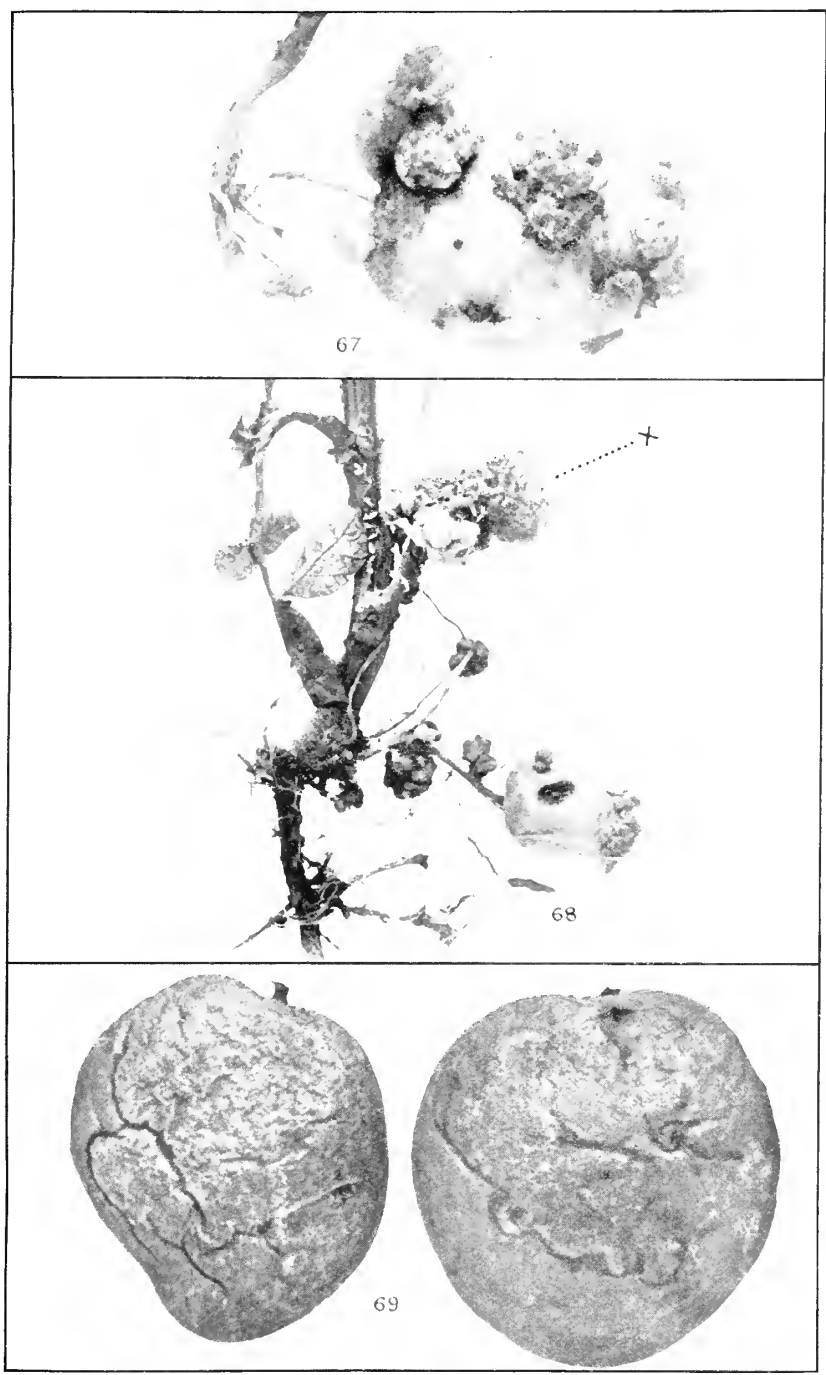

SCAB ON POTATOES-BELOW AND ABOVE GROUND 




\section{PLATE XXIII.}

Fig.

DRY RO'T, WHITE ROT, OR "BROWN RING."

70. Potato showing White Rot Fungus or Fusarium.

71. Healthy potato which was artificially infected at wound and fungus appeared as shown in sixteen days.

72. Advaneed stage of same two montlis after infection.

73. Filaments of fungus with conidia attached and still immature .. $\quad \ldots \quad \times 500$

74. Conidia detached and showing generally three cross-partitions $\quad \ldots \quad \times 500$

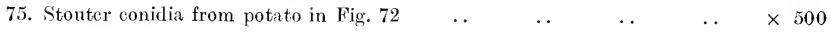


Piate XXIII.

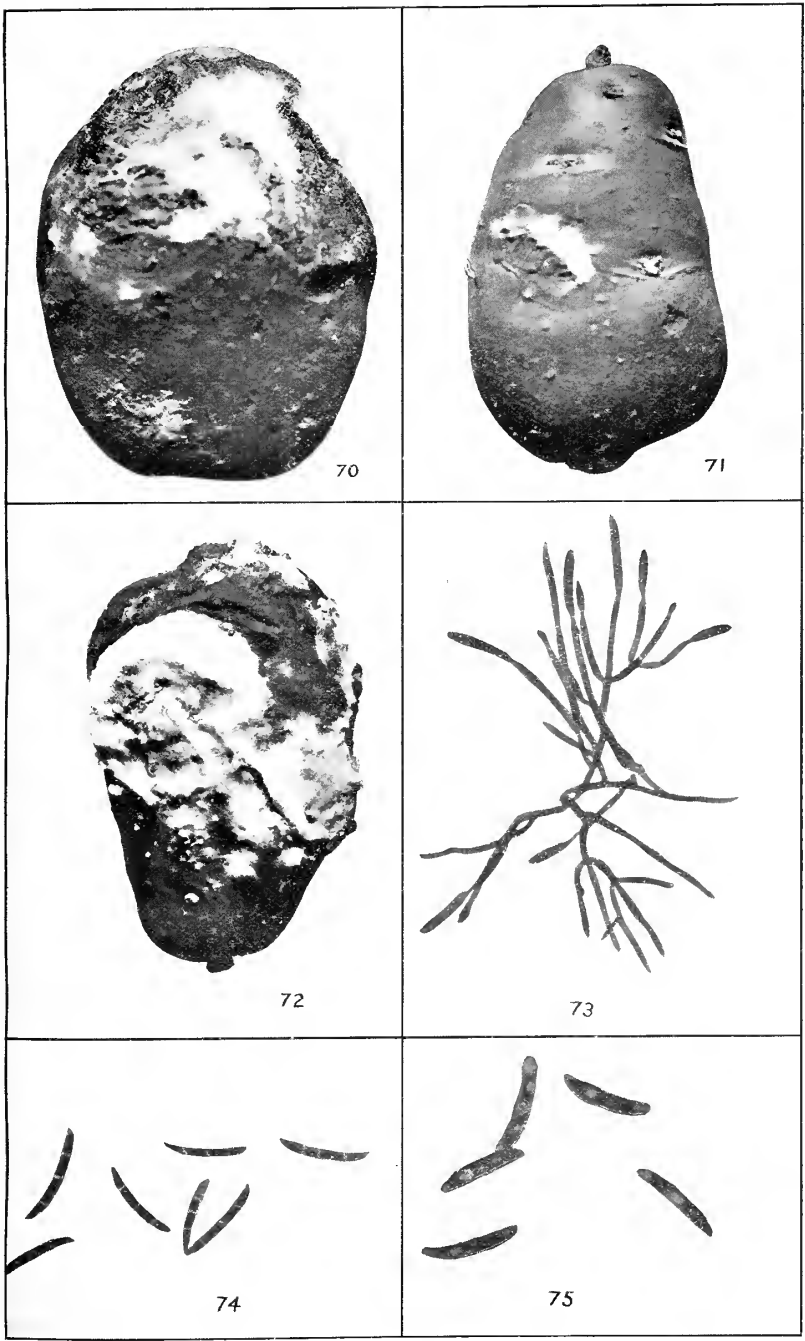

C. C. Brittlebank, Phot. 
, 


\section{PLATE XXIV.}

Fig.
76. Conidia germinating at one end and producing slender filament, $\quad . \quad \times 170$

\section{DRY ROT, WHITE ROT, OR "BROWN RING."}

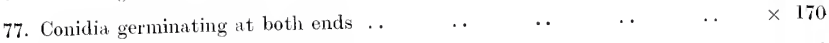

78. Single stout conidium germinating at both ends $\quad \ldots \quad \ldots \quad \ldots \quad \ldots \quad \times 500$

79. Single conidium germinating at both ends, and bearing secondary conidium at end

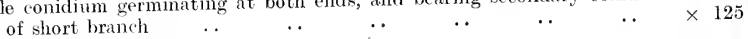

80. Conidia germinating after being kept moist for 28 hours, the germ-tubes adjoining becoming connected by cross-tubes

81. Conidia germinating and producing clusters of conidia at end of short branches-

A. Conidium germinating and producing on short branch a tuft of secondary

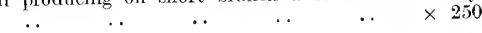

B. Showing larger tufts of secondary conidia $\quad \ldots \quad \ldots \quad \ldots \quad \ldots \quad \times 250$

(C. Tufts of secondary conidia highly magnified and showing septate or jointed conidia 
Plate XXIV.

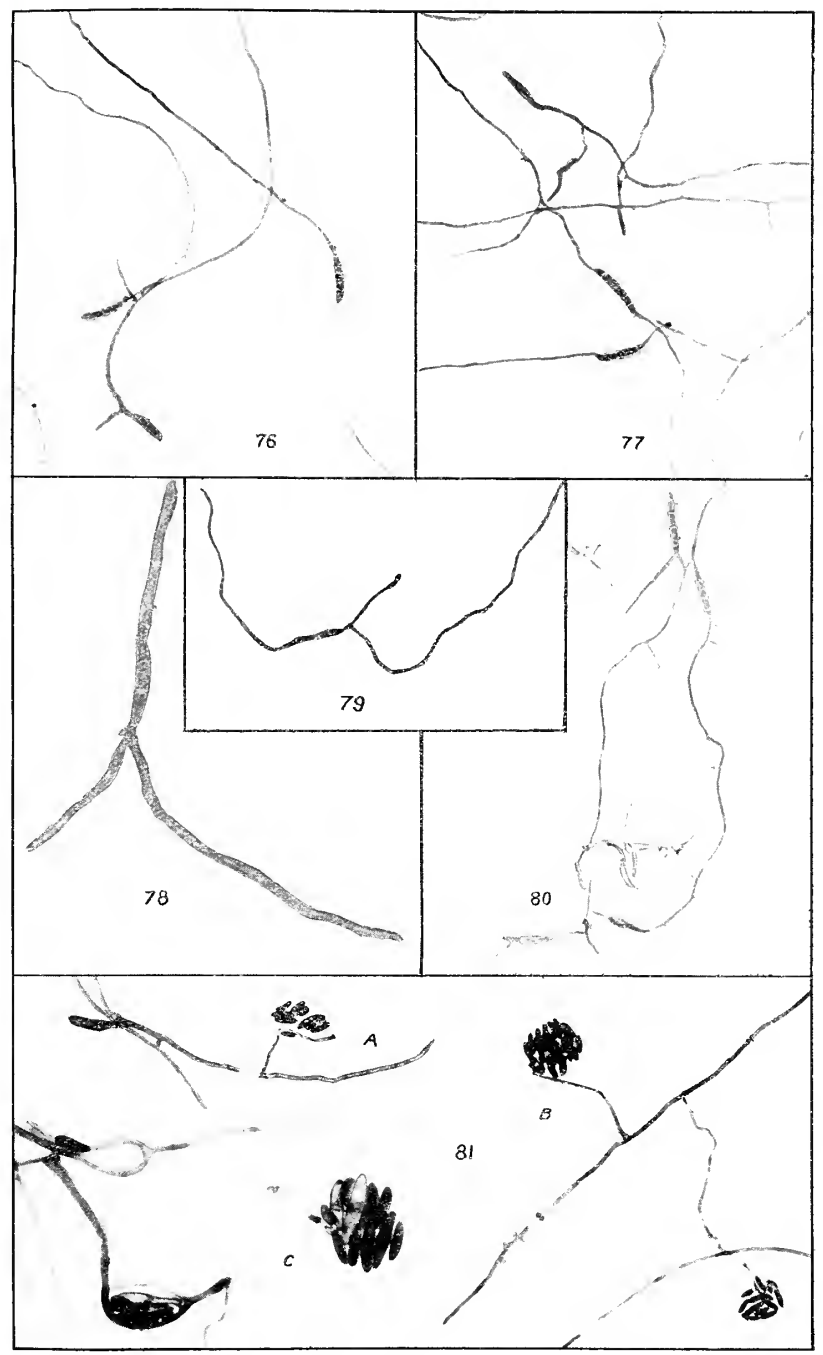

C. C. Brittlebank, Phot.

CONIDIA GERMINATING

$\times 125,170,250$, and 500 

9276. 


\section{PATE XXV.}

\section{DRY RoT, WHTER ROT', OR "BROWN BING."}

Fig.

82. Constia producing Resting-squres. cither at the apes of at short projection from the ent, or by converting one of its suguents into a rest ing-spore which grives rise to . $\times 500$

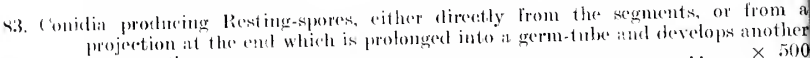
sipore at the alpex ..

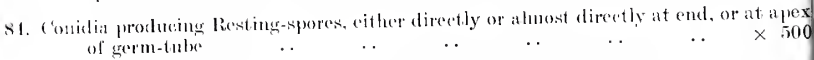

s.5. (iromp of five Rest ing-spores, thick-walled and irregralar on the surfate . . $\times$,500

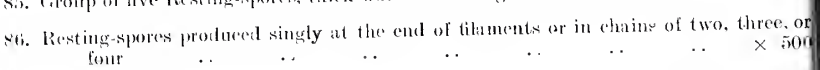


Plate XXY.

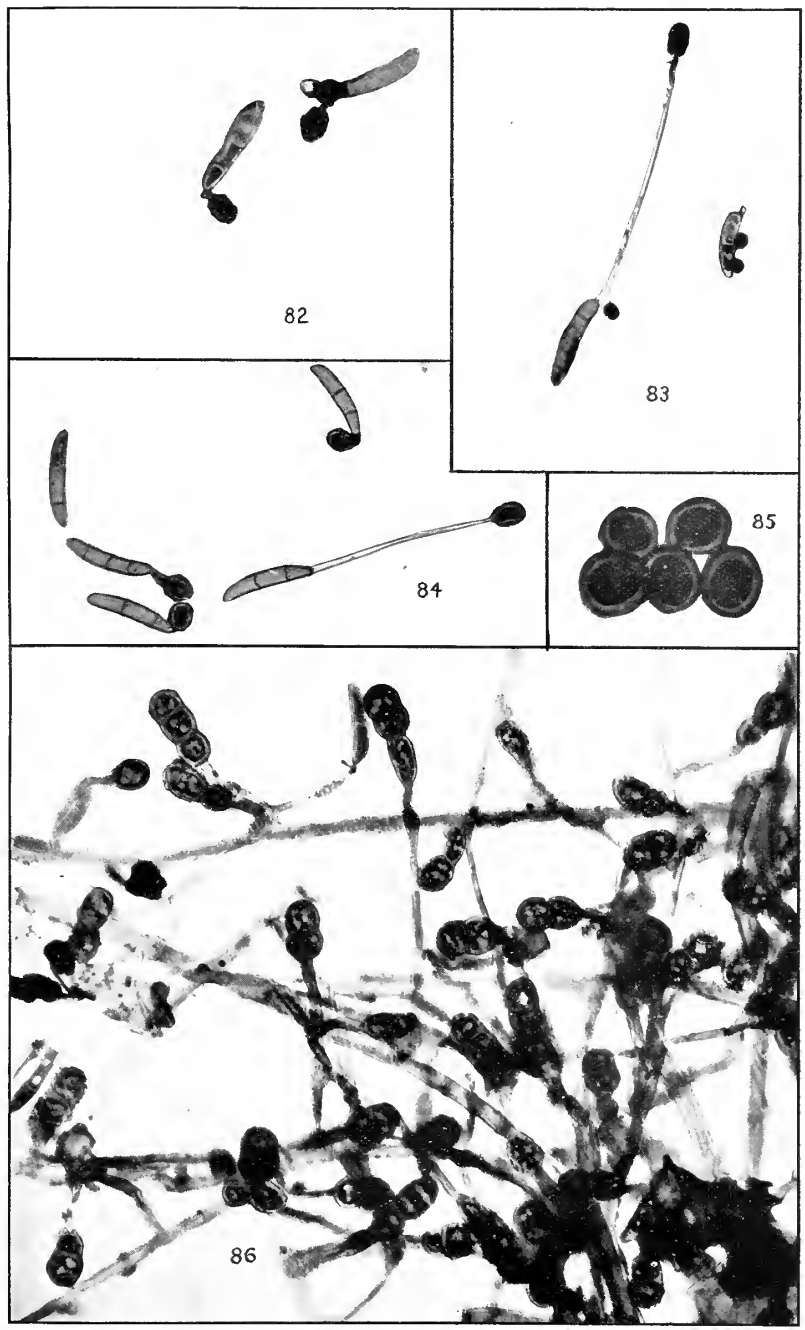

C. C. Brittlebank, Phot.

CONIDIA PRODUCING RESTING SPORES 




\section{PLATE XXVI.}

\section{DRY ROT, WHITE RO'T, OR "BROWN RING."}

Fig.

87. (onidium at top producing clongated germ-tube, with normal Resting-spore at ajex and knols at intervals along the tube. These swellings are probably immature $\begin{array}{llllllll}\text { liesting-sprores } & \ldots & \ldots & \ldots & \ldots & \ldots & \ldots & \times 170\end{array}$

88. Longitudital stiee of potato, showing vascular bundle ring (strined by malachite green).

89. Different slices of the one potato, showing "brown ring."

90. Healthy Tom:to infected with conidia from potato and producing White Rot. 
Plate XXVI.

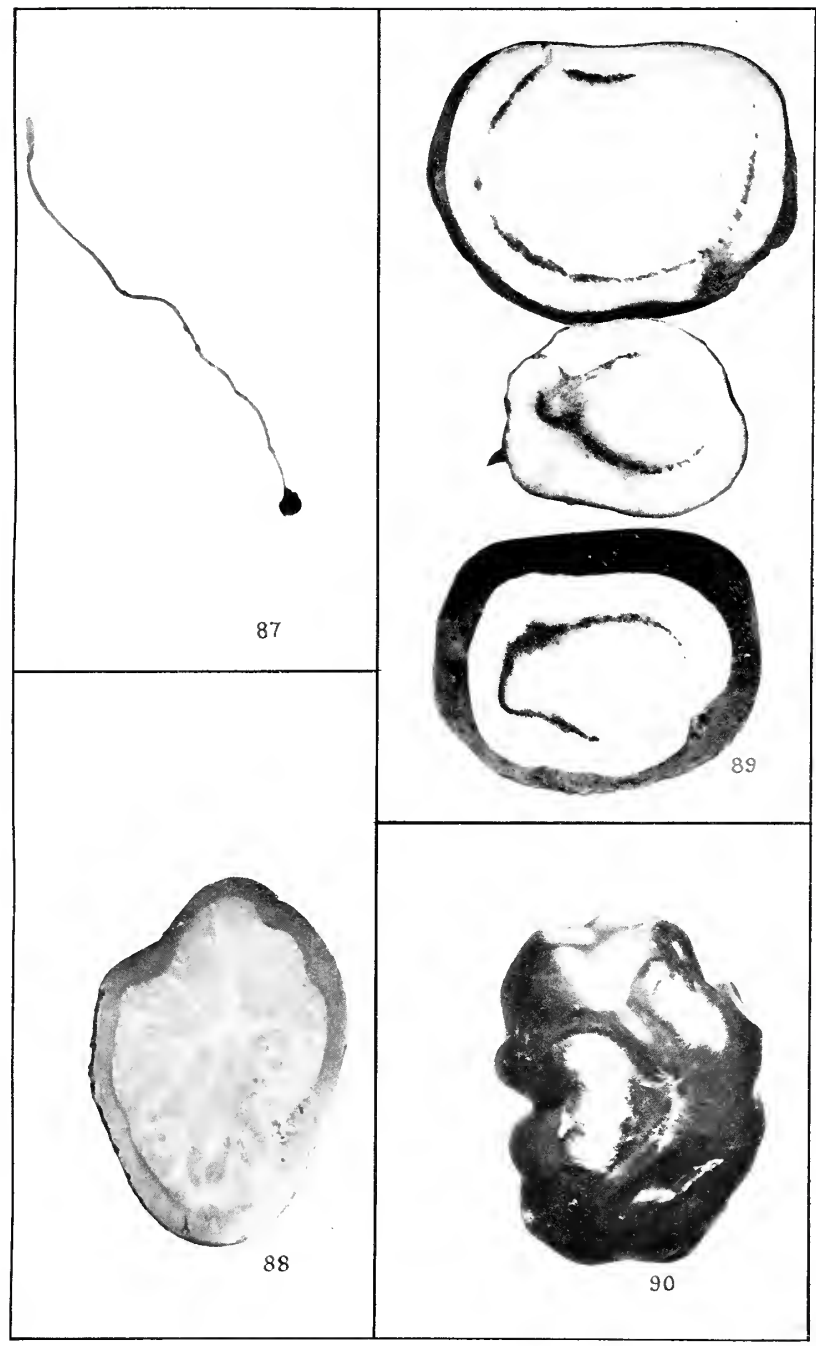

C. C. Brittlebank, Phot. 




\section{PIATH XXIII}

\section{Fig.}

\section{WET RO'T OR BROINN RO'T.}

91. Potitu with "Siore "res" or "J' Jumy eyes" the early stage of the disense when

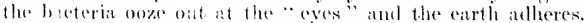

92. Siction of putnto, sluwing discoloured ring. owing to vasenlat bundles being filled with bateteria which oo\% out. in slimy dirty-white masses.

93. Potato with Brown Rot and White Rot rombined. 
Prate XXVII.

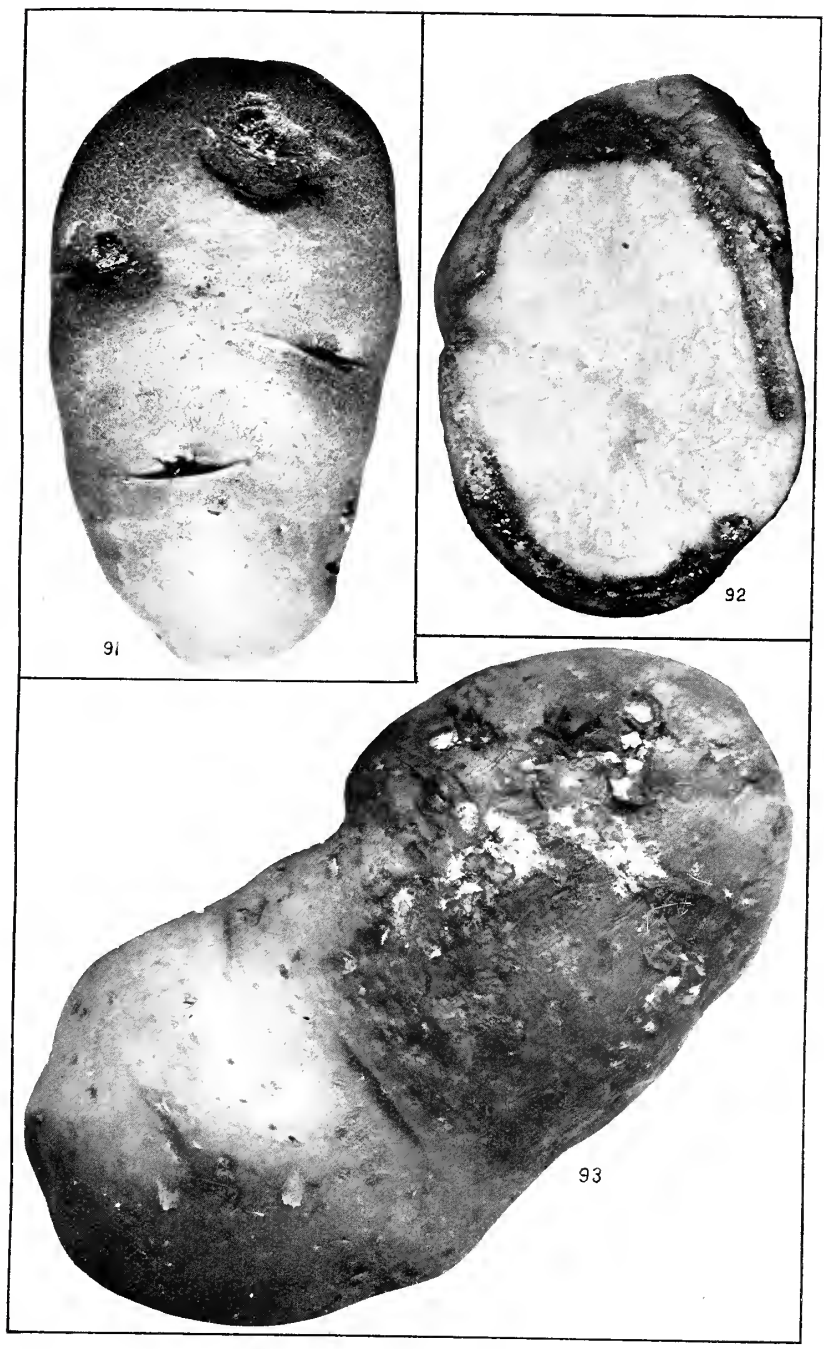

SORE EYES AND BROWN ROT 




\section{PIATE XXVIII.}

Fig.

\section{WET POT OR BROWN ROT.}

94. Section from one potato, showing Brown Rot extending from ring of vaseular bundles inwards and outwards.

95. Potrito preserved in sirit. showing the bacteria oozing out in dense, long, eurling. worm-like whitish masses. The water being withdrawn by the spirit, the ressels contracted and forcel out the bacteria in solid masses.

"THREADY EYE."

96. Potato sprouted and producing slender thread-like shoots. (This Figure is placed here for convenience and has no connexion with Wet Rot.) 
PJITE XXYIII.

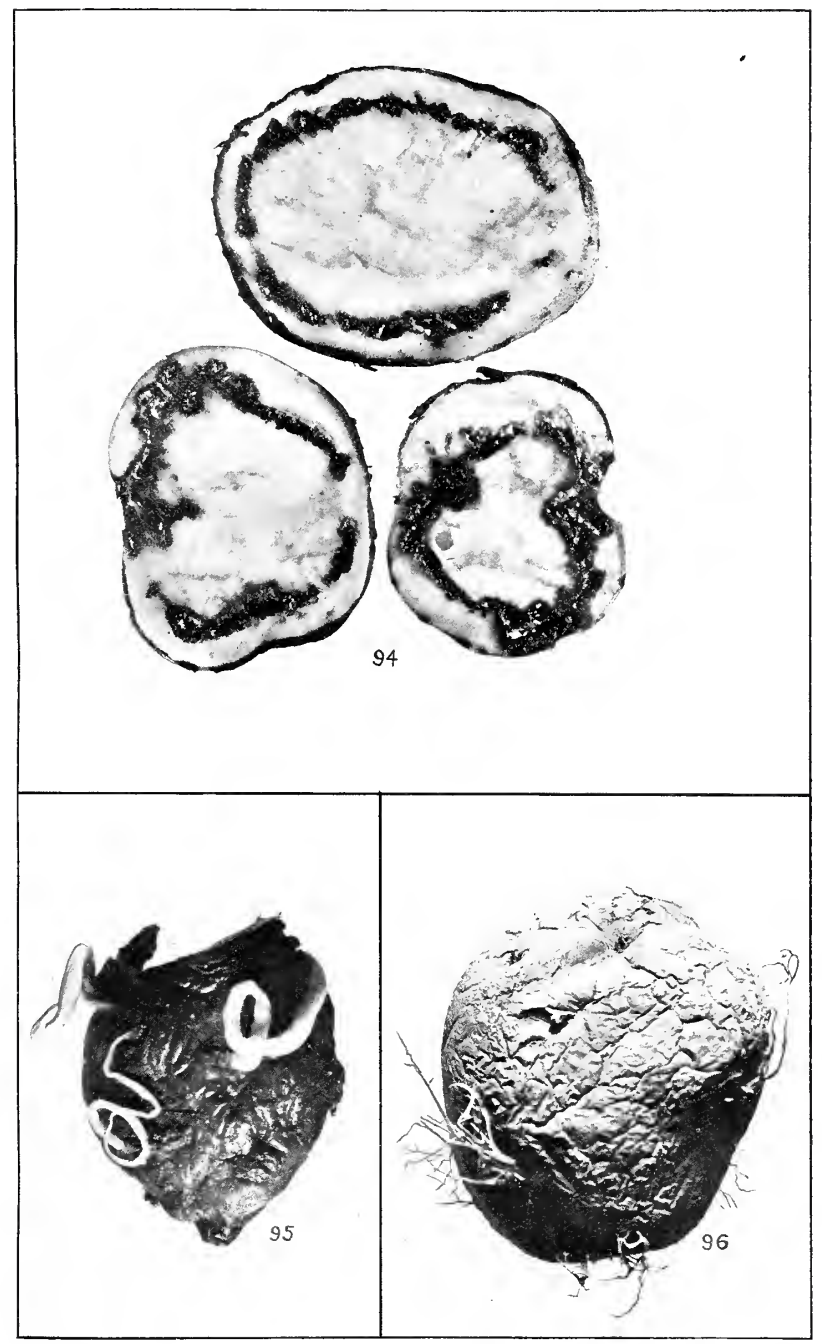

C. C. Brittlebank, Phot, 




\section{PİATE XXIX.}

(Afler I). Erwin F. Smith.)

Fig.

\section{WET ROT OR BROWN ROT.}

97. Symptoms produred by infection of Bacillus solanacearum on stem, leaf, and tuber of potato plant-

1. Shrivelled up stem fifteen days after infection at $x$.

2. C'ontrol plant healthy.

$3,4,5,6,7$. Thubers in various stiges of infection.

8. Section through the basal portion of an infected stem.

98. Section through the lowest portion of infected stem at point $y$. The bacteria are

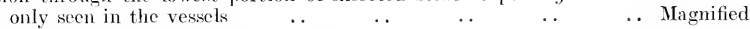

99. Simall portion of preceding Figure magnificd, to show how some of the vessels are (rowded with bacteria 


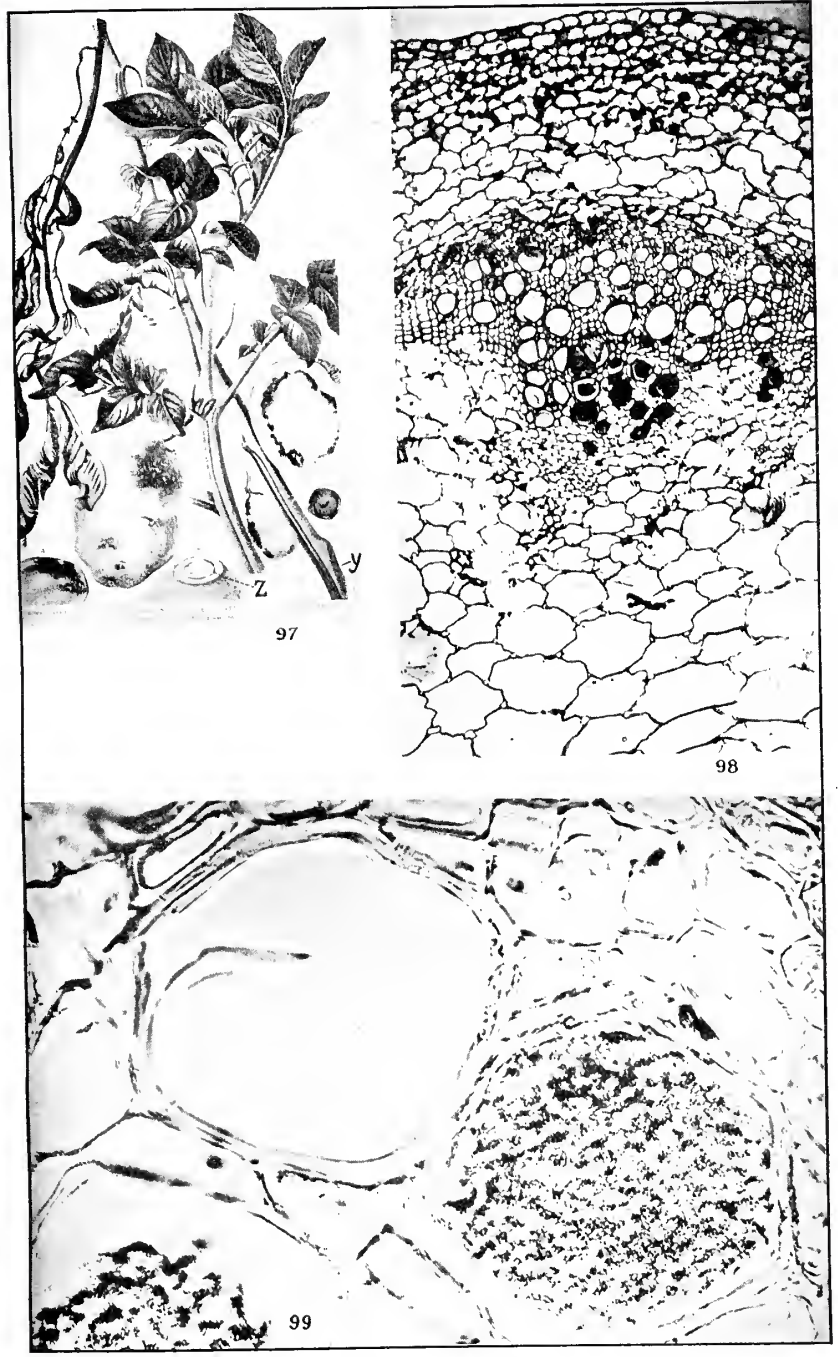

Reduced and Hishly Mas. 
. 


\section{PLATE XXX.}

Fig.

\section{SCLEROTILM, STRIXGY ROT, AND BROWN FLECK.}

100. Portion of potato stem, showing one sclerotium in eavity and the same isolated at side.

101. Section of sclerotium showing interlacing network of filaments, darker, denser, and

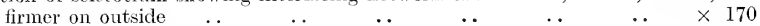

102. Potato with strands of Root Rot fungus (Armillaria mellea) growing over tuber and hanging down in long threads.

103. Section of potato, showing brown spots, or "Fleck," in the flesh. 


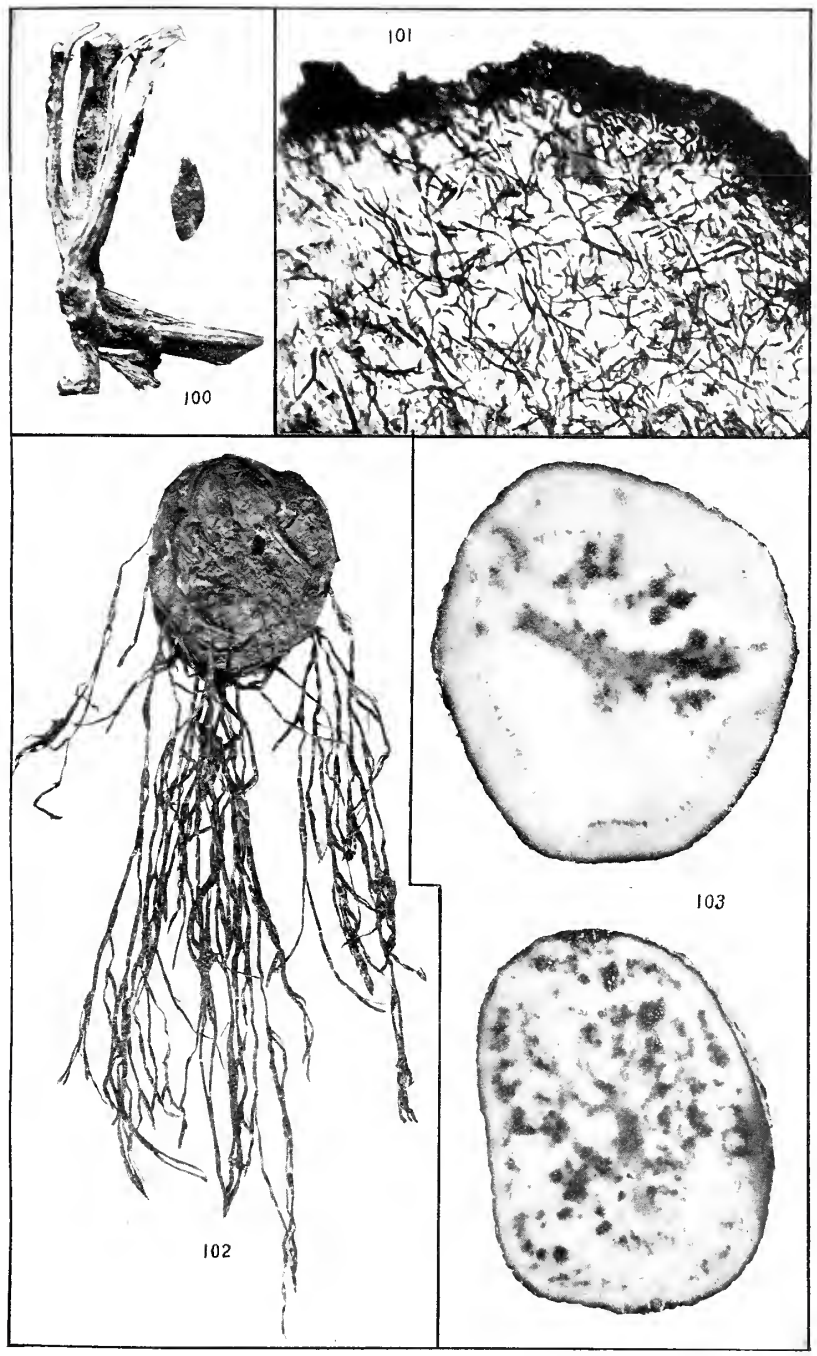




$$
\text { . }
$$




\section{PLATE XXXI.}

\section{BROWN FLECK AND STRINGY ROT.}

Fig.

104. Cross-section of potato, showing internal brown spots.

105. Section lengthwise of young tuber with "Brown Fleck."

106. Surface view of tuber with network of stringy fibres of Armillaria mellea.

107. Section of same, showing rot extending inwardly.

108. Section of potato, showing discoloured tissue mottled with white fungus arising from black strands on outside. 


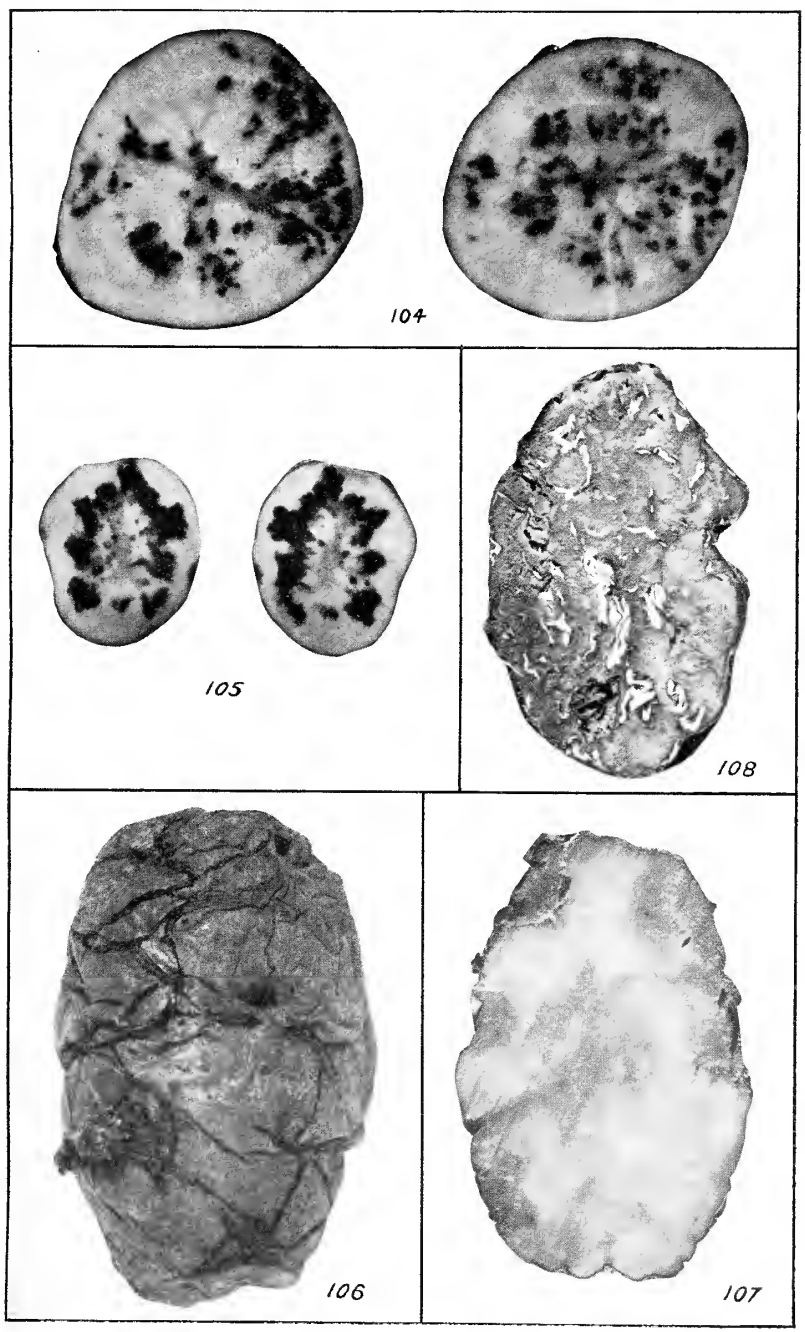

C. C. Brittlebank, Phot. 



\section{PLATE XXXII.}

\section{POTATO BLIGHT.}

Fig.

(Continued.)

109. Self-sown healthy potito plant, showing the formation of tubers. The old "set" is at the base, and the underground branehes are produeing tubers of various sizes.

The Stem end of the potato is variously ealled "Navel" or "Heel."

The Crown is also ealled the "Rose" or terminal end. 
Plate XXXII.

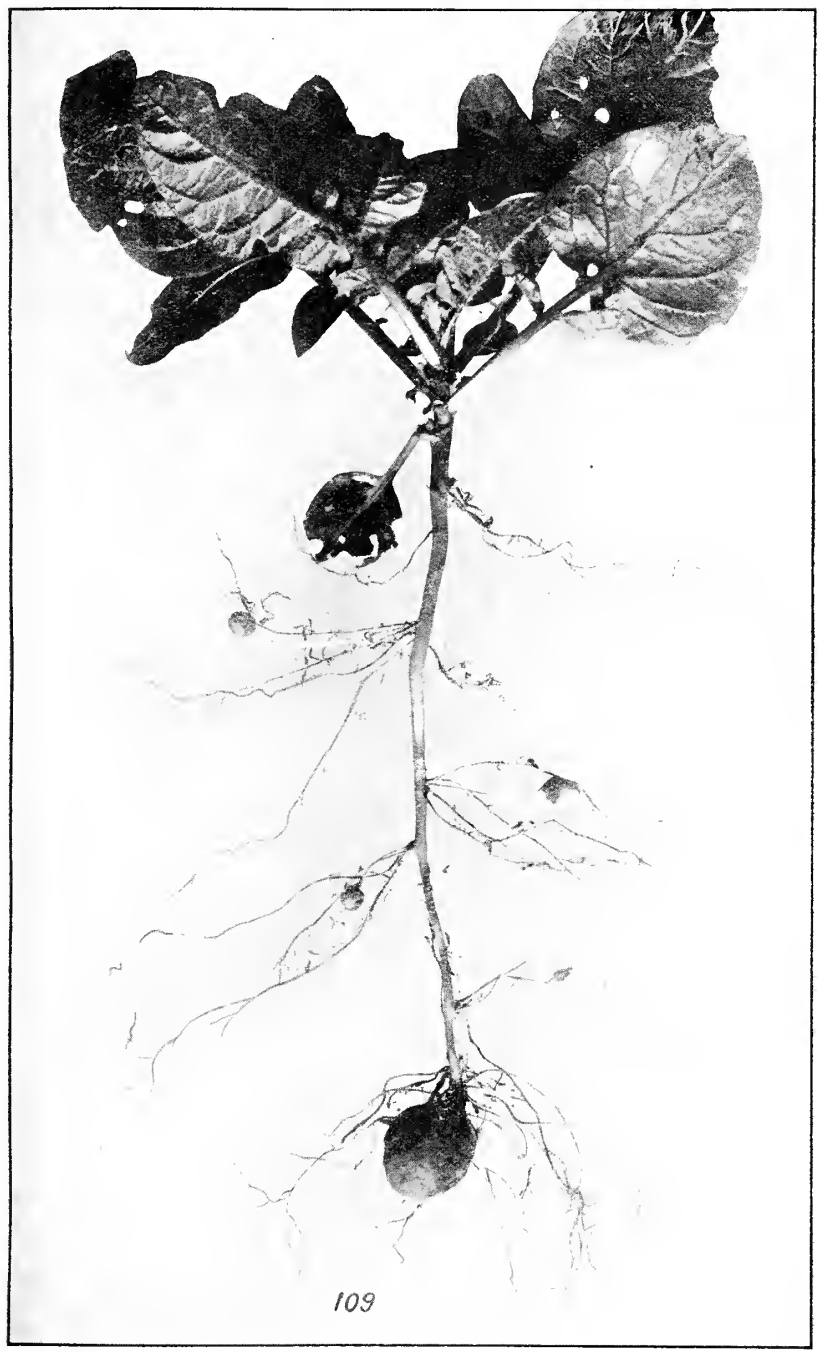

C. C. Brittlebank, Phot. 




\section{PLATE XXXIII.}

\section{POTATO BLIGHT.}

Fig.

110. Young potato-plant from Killarney with diseased tops and tubers. The leaves are all withered, the stems blackened, and the tubers all affected.

111. The " berry," "apple," or " plum " of the potato, covered with the fructification of the Blight fungus while still growing on the plant. 


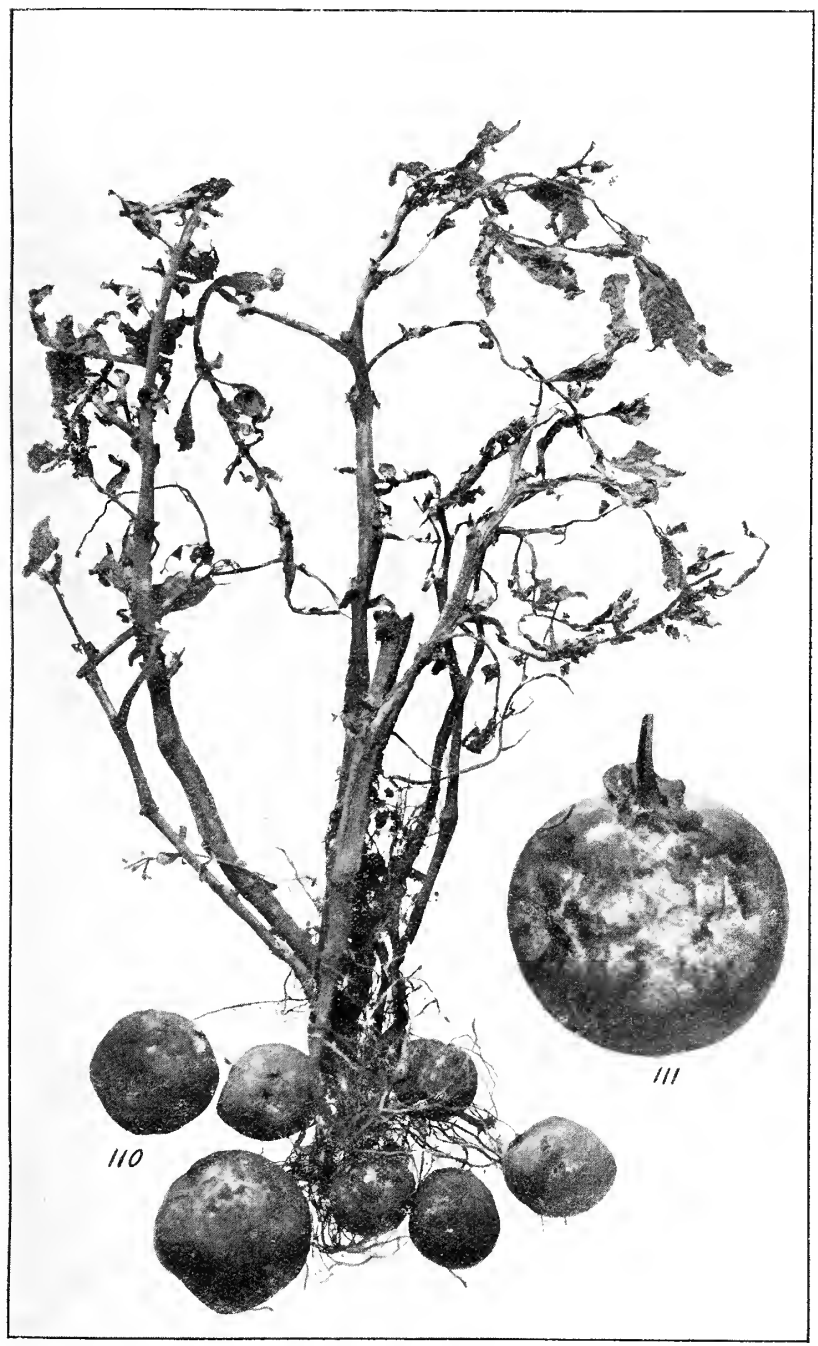

C. C. Brittlebank, Phot.

Reduced and Enlarged YOUNG POTATO PLANT WITH IRISH BLIGHT 
, 



\section{PLATE XXXIV.}

\section{POTATO BLIQH'T.}

Fig.

112. Under surface of tliseased leaflets, showing the white mould.

113. Upper surface of leaflet, with white moule.

Although usunlly developed on the under surface, it is not uncommon on the upper.

114. small diseased potato borne above ground in the axil of a leat. 
Plate XXXIV.

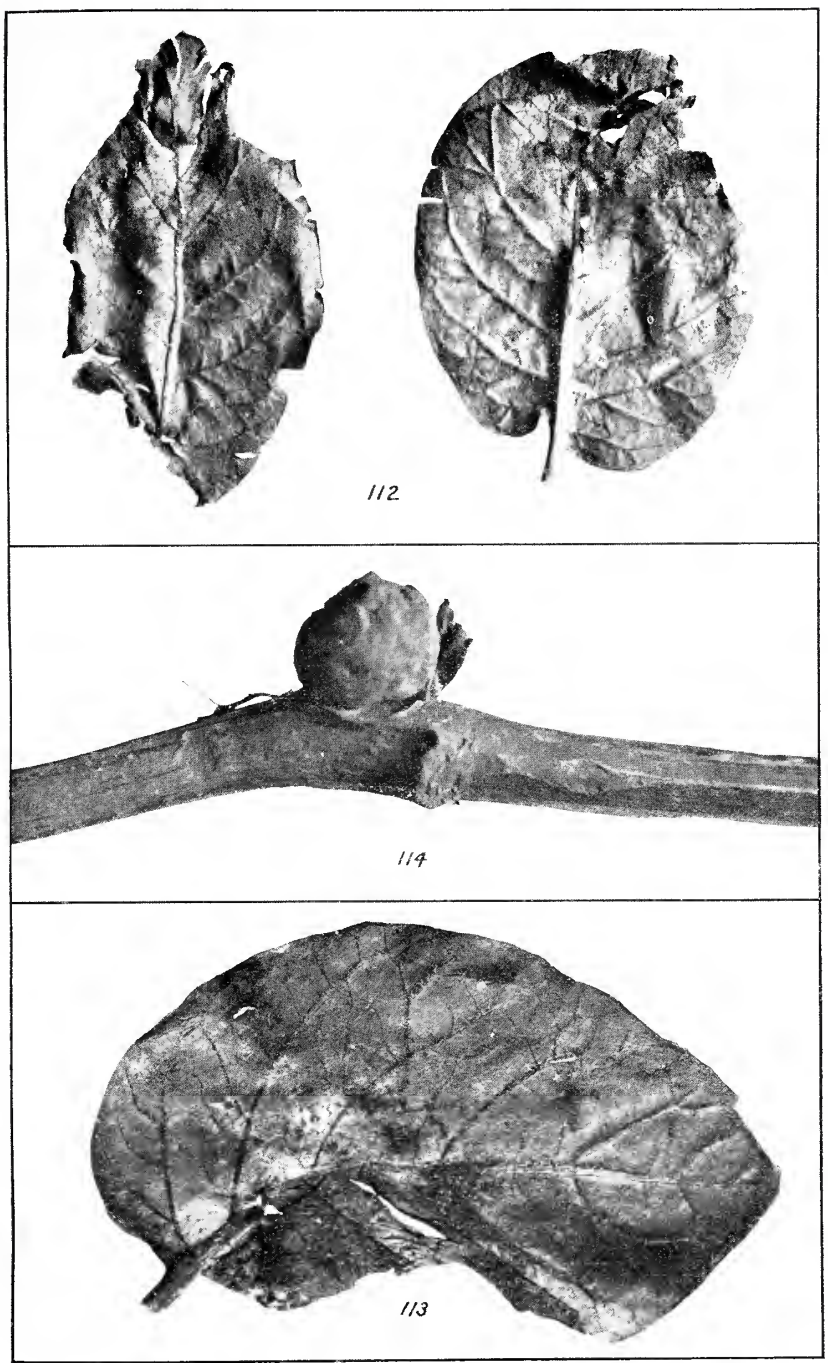

C. C. Brittlebank, Phot.

Nat, Size

LEAFLETS, AND POTATO WITH IRISH BLIGHT 


\section{PLATE XXXV.}

Fig.

\section{POTATO BLIGHT.}

115. Clein pot tto infected with sporangia beneath skin (8.7.10), showing the effect pro-
duced in 22 days-surface view and section. 116. Section of potato with disease arising from stemn

from mycelium passing along underground branch. 
Plate XXXV.

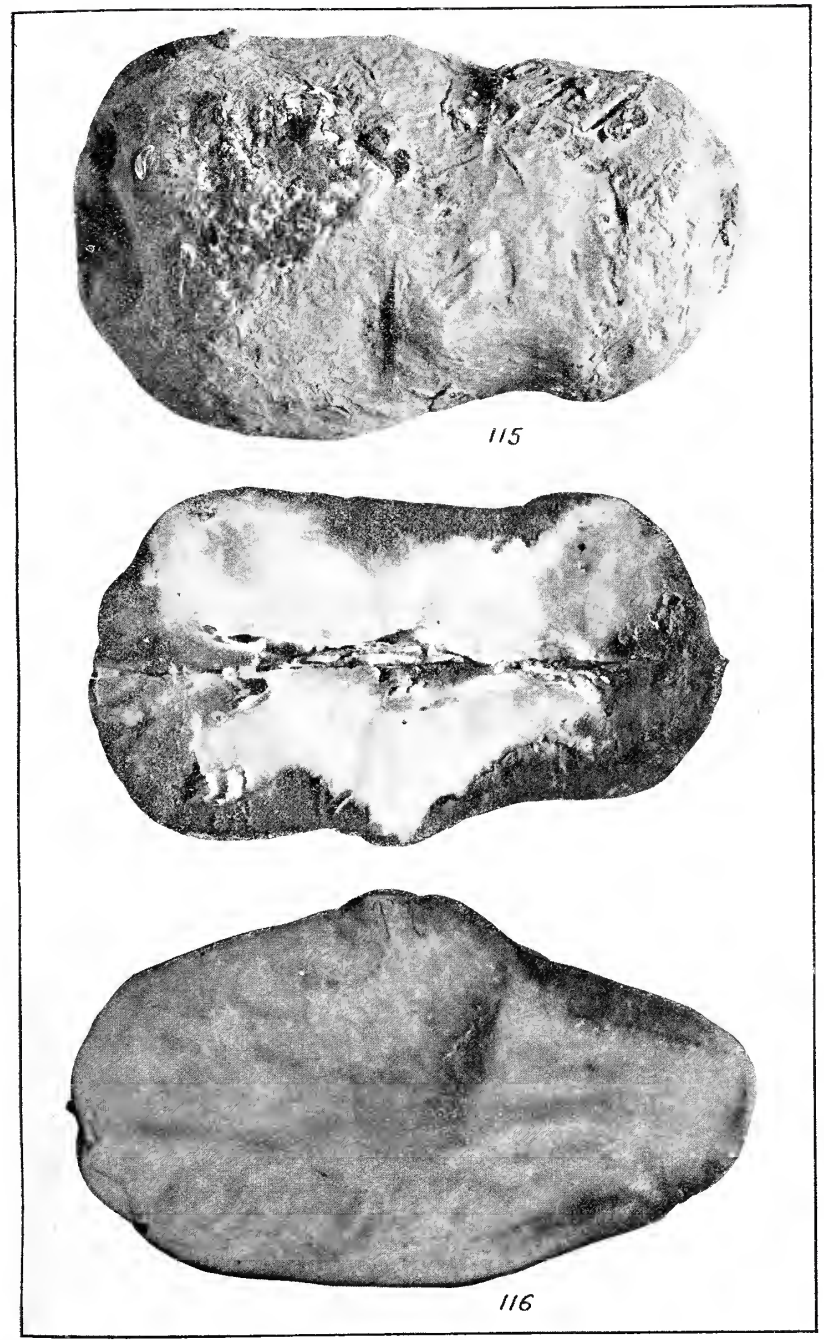

C. C. Brittlebank, Phot.

Nat. Size.

CLEAN POTATO INFECTED, AND INFECTION FROM STEM END 



\section{.}




\section{PLATE XXXVI. \\ POTATO BLIGHT.}

Fig.

117. Experimental plot planted with badly blighted potatoes, 7 th November, and shown after about twelve weeks' growth. 
Prate XXXVI.

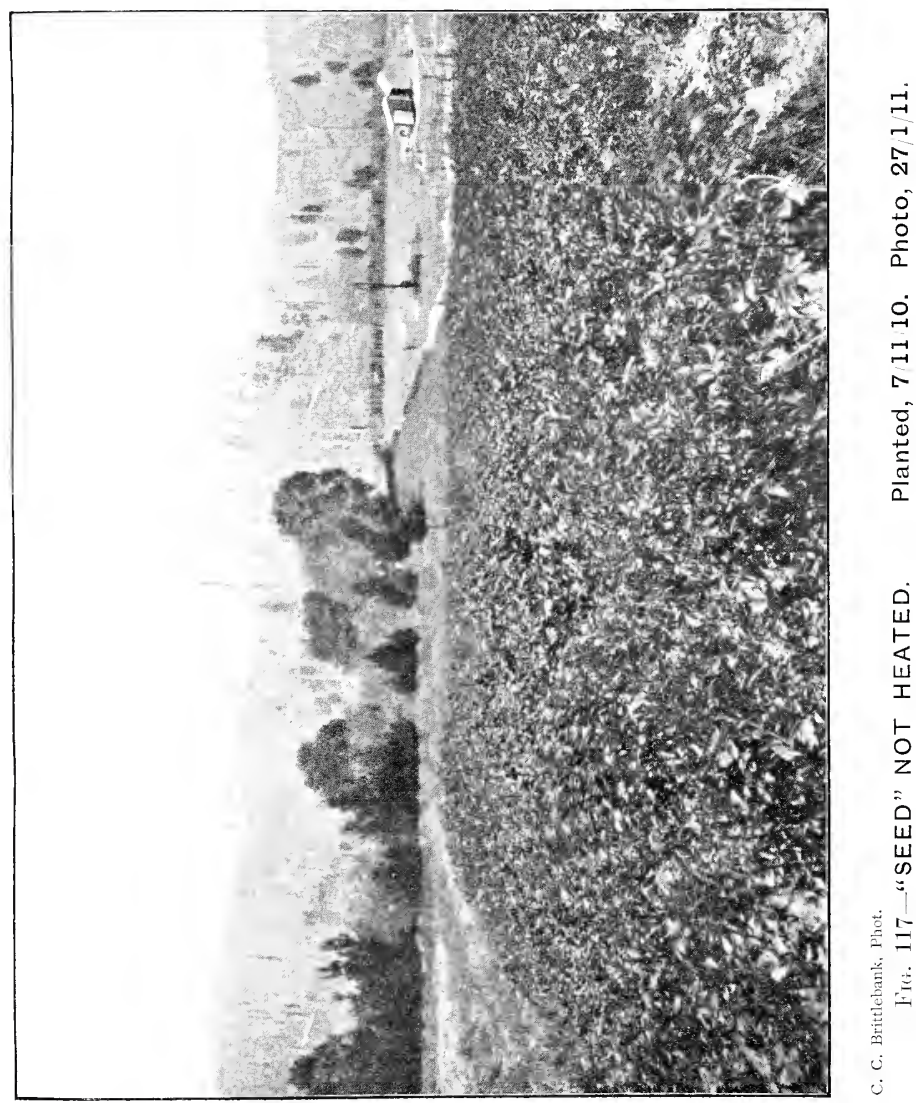





\section{PLATE XXXVII.}

Fig.

\section{PO'TATO BLIGHT.}

118. Portion of sume field with dise.used "sets" heated before planting. 
Piate AXXYII.

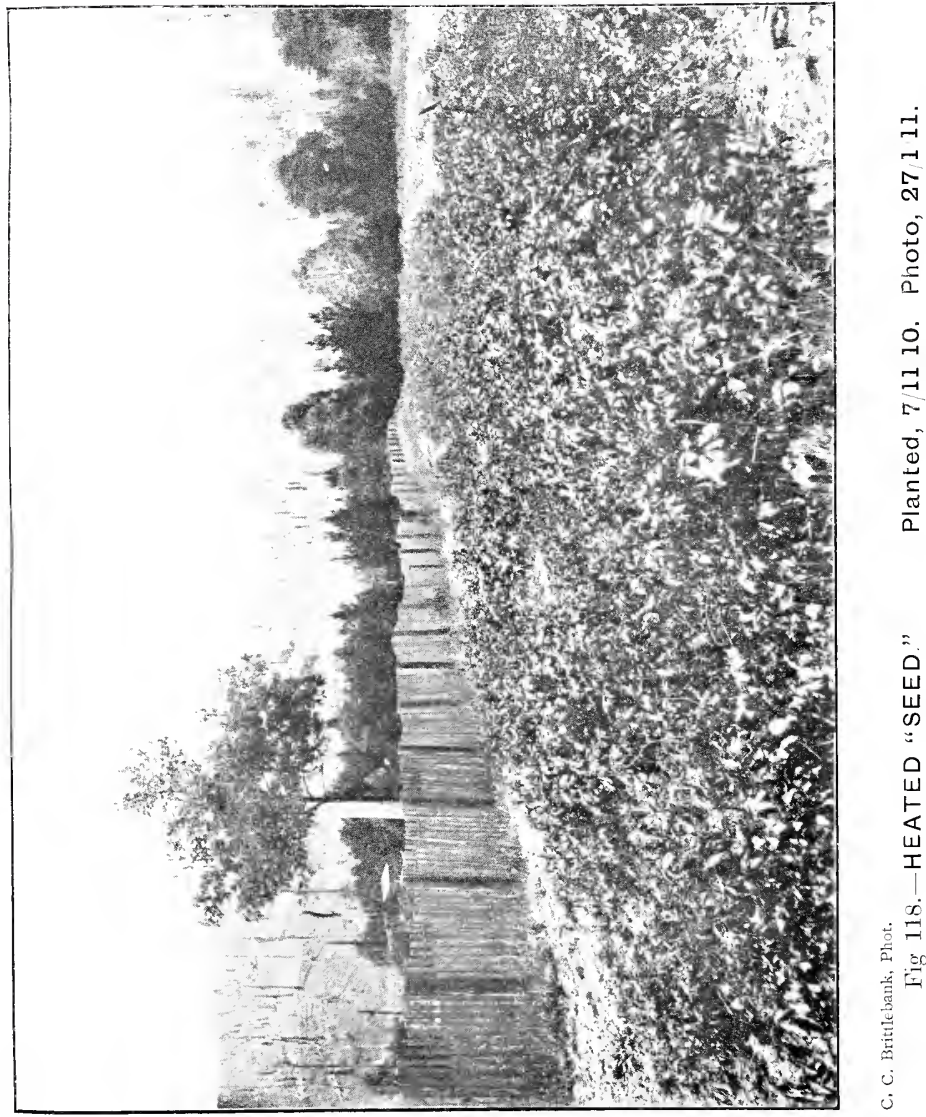





\section{PLATE XXXVIII.}

Fig.

\section{POTATO BLIGHT.}

119. Young plant of Kungaroo Apple (Solanum aviculare) with stem and leaves showing a luxuriant growth of Irish Blight fungus. 
Piate XXYili.

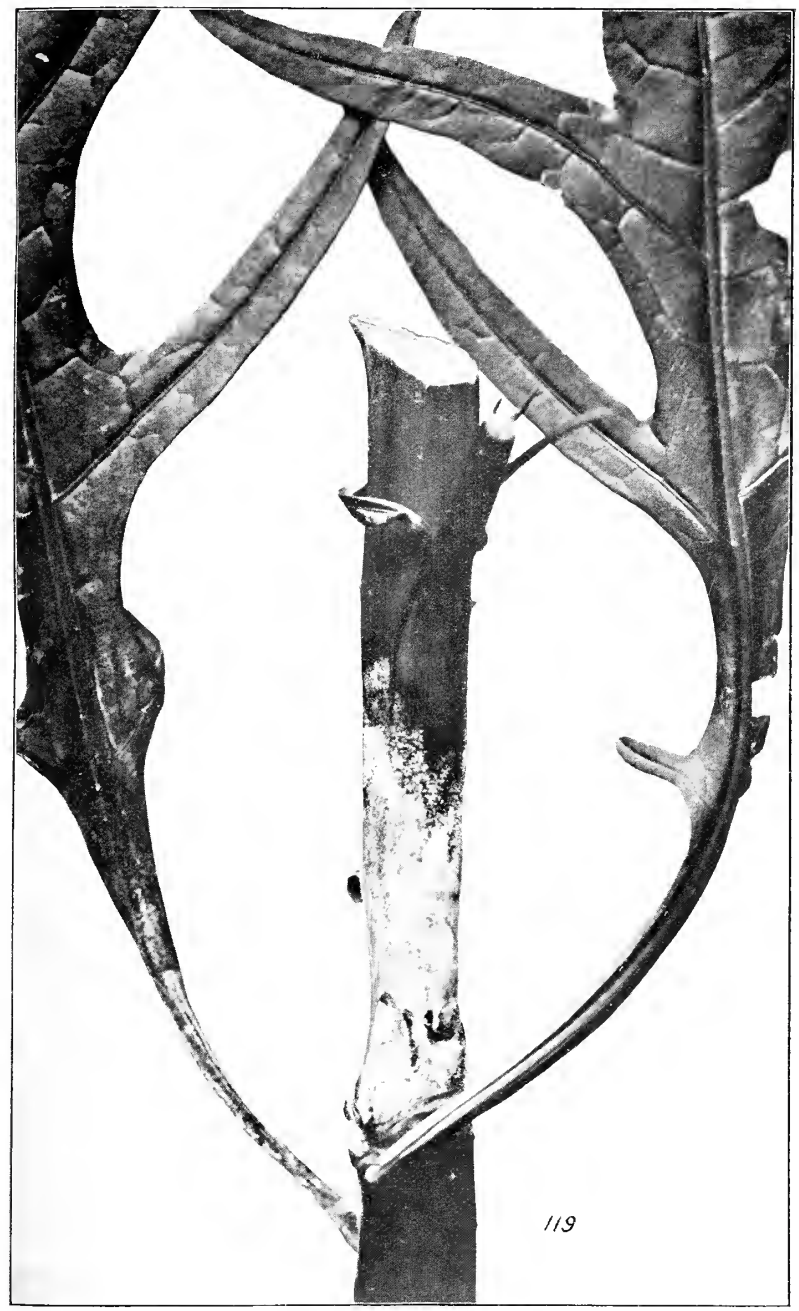

C. C. Brittlebank, Phot.

KANGAROO APPLE

Nat. Size

STEM AND LEAVES WITH IRISH BLIGHT 



\section{PLATE XXXIX.}

\section{RHIZOCTONIA ROT.}

Fig.

(Continued.)

120. Rhizoctonia as a white fungus at "collar" cxtending above and below ground.

I2I. Rhizoctonia causing cracking and fissuring of potatoes. 
Plate XXXIX.

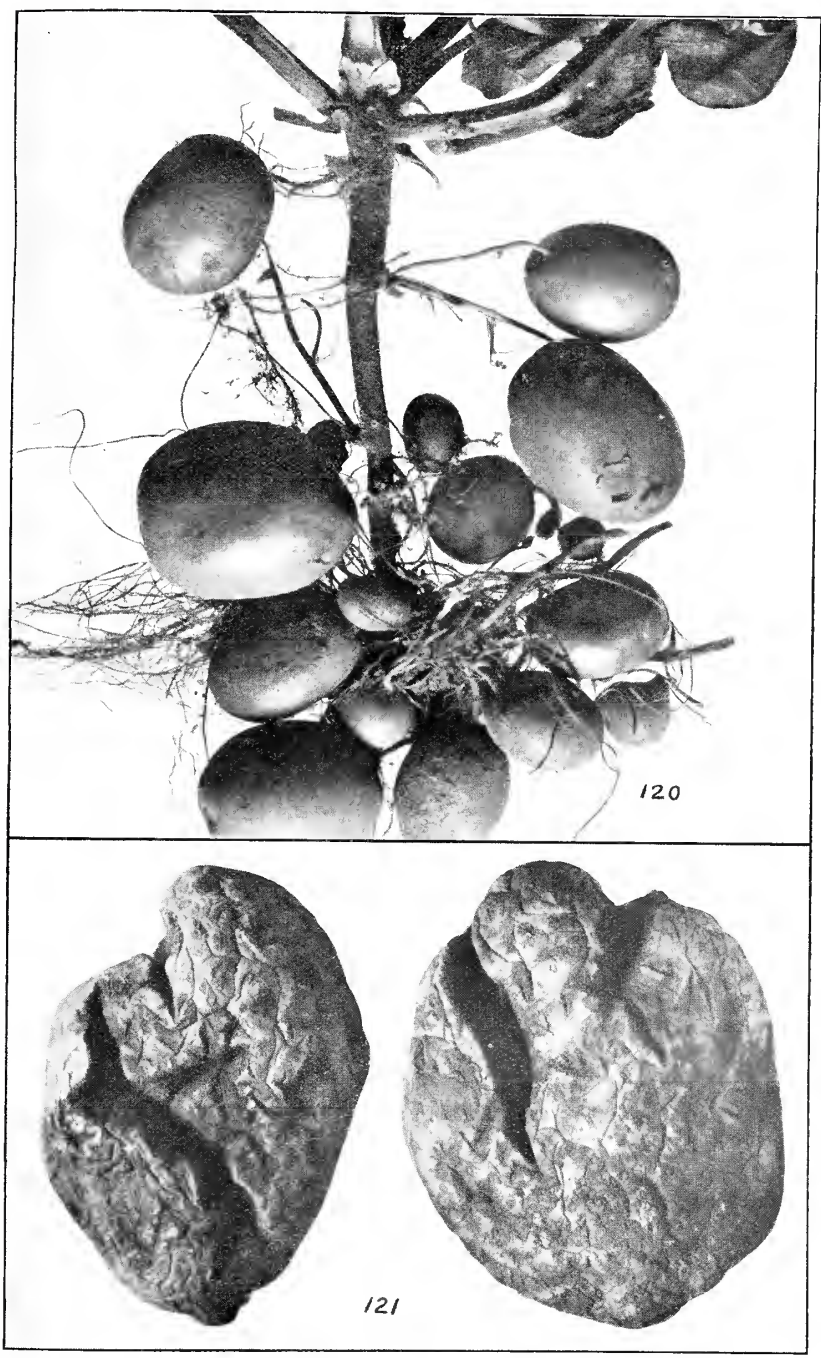

C. C Brittlebank, Phot.

Reduced and Nat, Size

RHIZOCTONIA AT "COLLAR" AND ON TUBERS 


PLATE XL.

Fig. RHIZOCTONLA RO'E.

l2:2. "Rosette" of Potato Plunt due to Rhizoctonia, showing the clovely-crowded leaves and aerial tubers. 


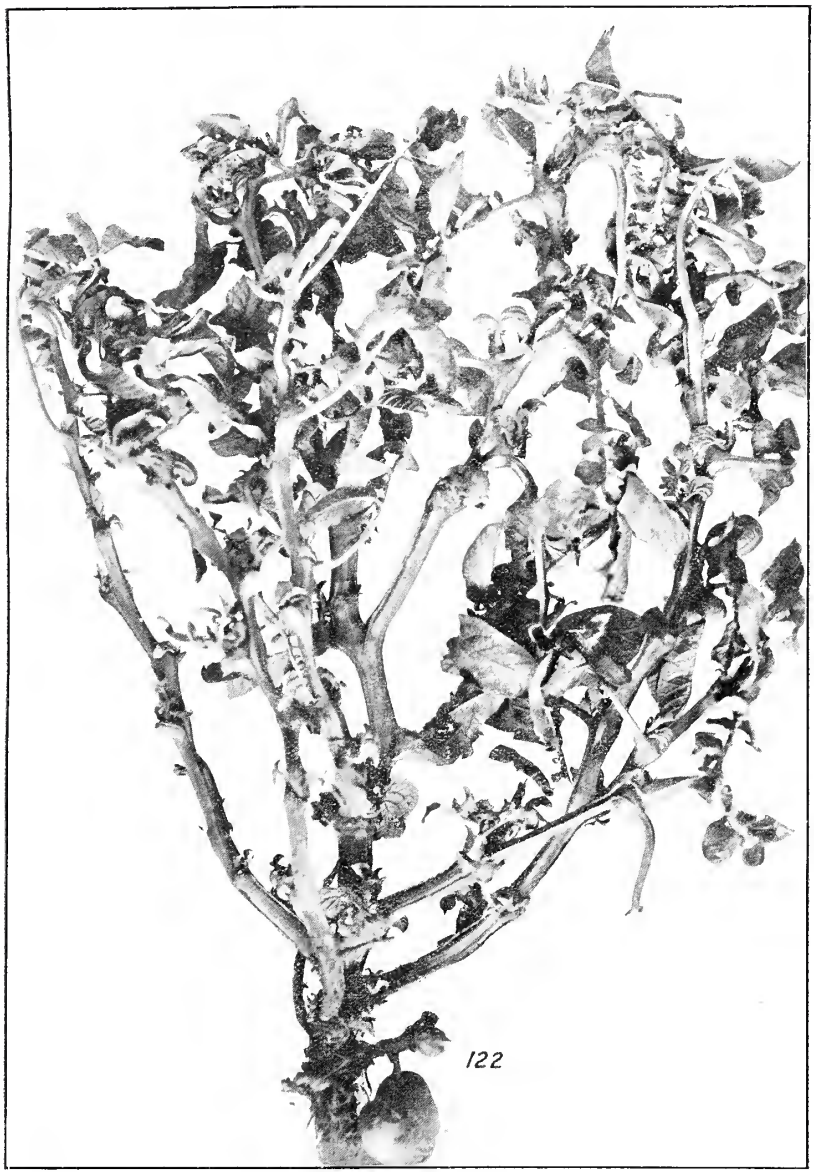

C. C. Brittlebank, Phot.

Reduced

ROSETTE OF POTATO PLANT DUE TO RHIZOCTONIA 

* 


\section{PLATE XLI.}

\section{RHIZOCTONLA ROT.}

Fig.

123. Aerial tubers associated with " rosette."

124. Rhizoctonia mould at base of stem, passing on to branches and aerial tubees 
Plate Xli.
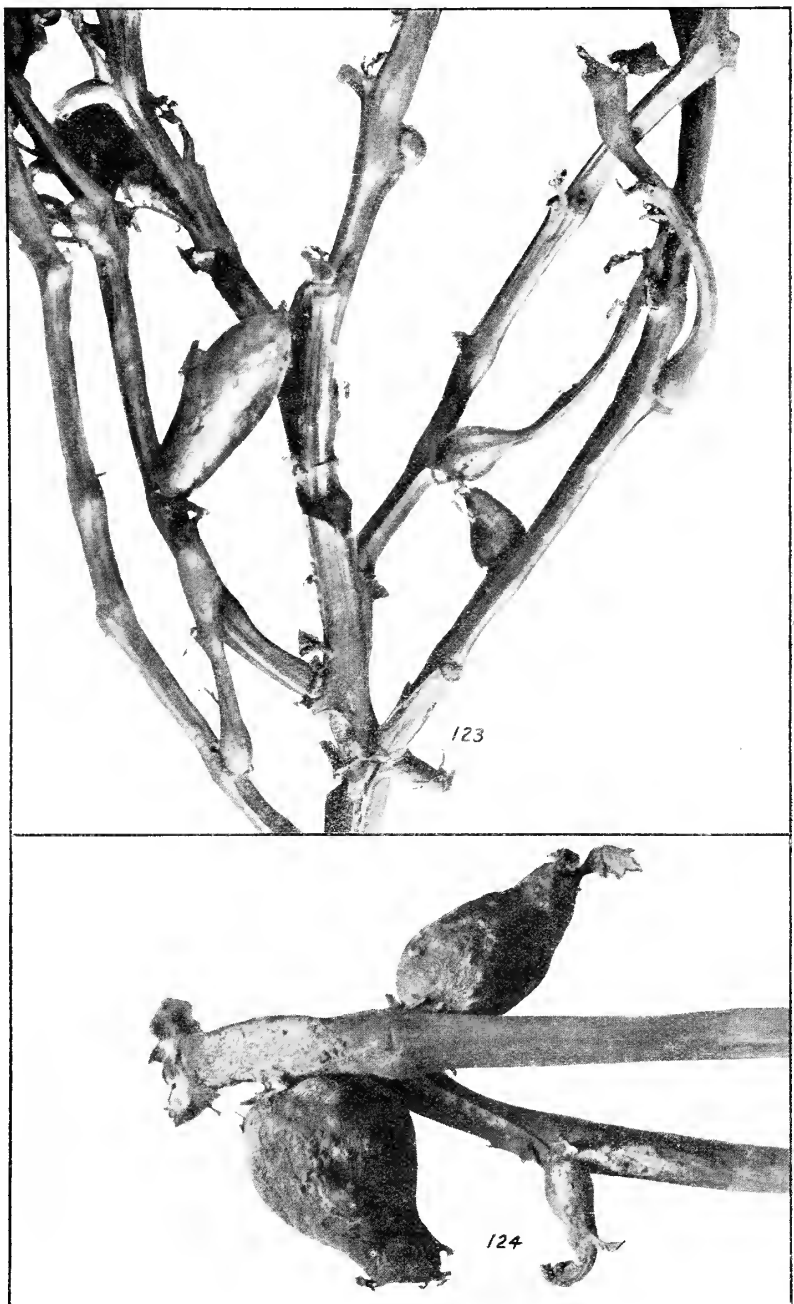

C. C. Brittlebank, Phot.

Reduced

RHIZOCTONIA MOULD ON STEM, AND AERIAL TUBERS 
- 
PI.I'li XIII.

S'SB

('omplantell.)

Fis.

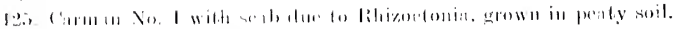


Piate XliI.

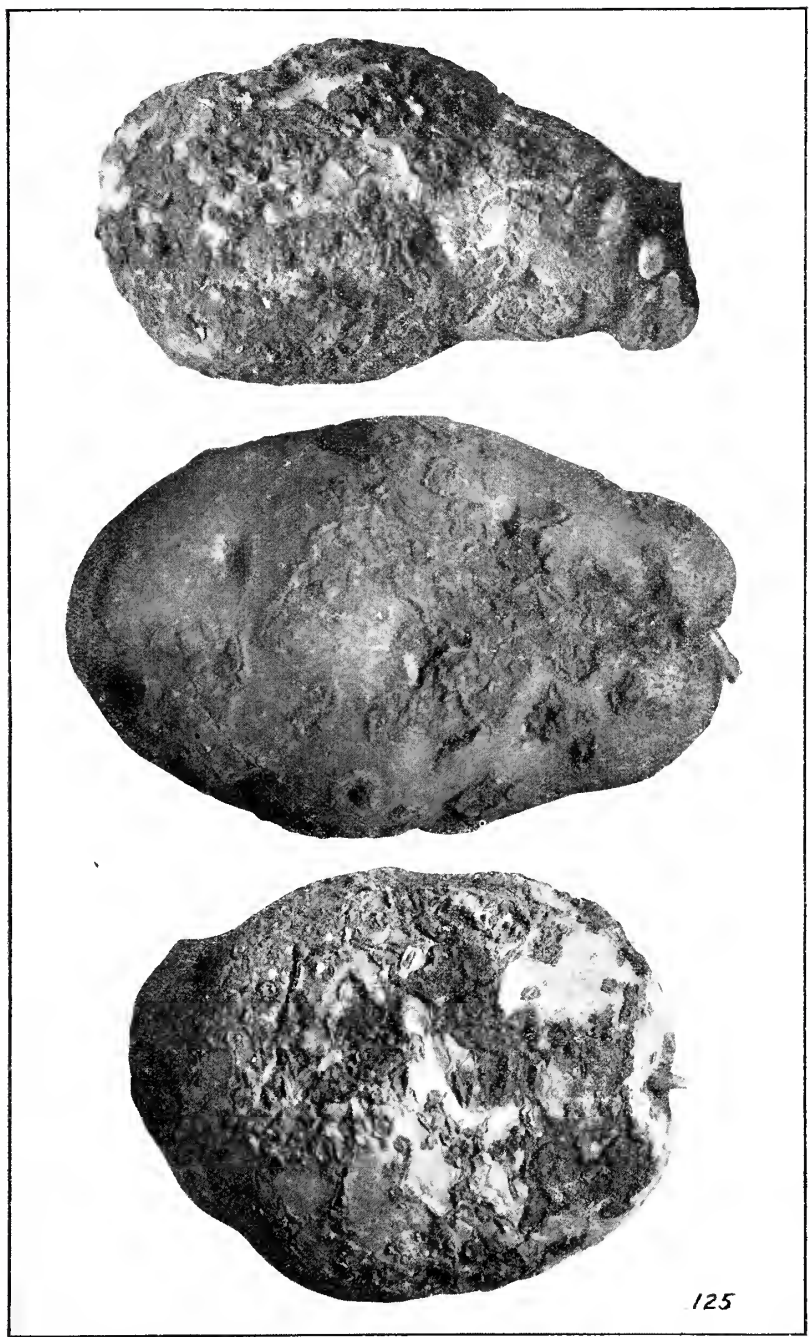

C. C. Brittlebank, Phot. 
H 2 


\section{P'A'TE XILII.}

Fis.

$N C A B$.

126. Garman No. I with Rhizoctonia scabl.

127. Hesporr seathes which apjears as a delicate whitish mould on surfite of serab. 


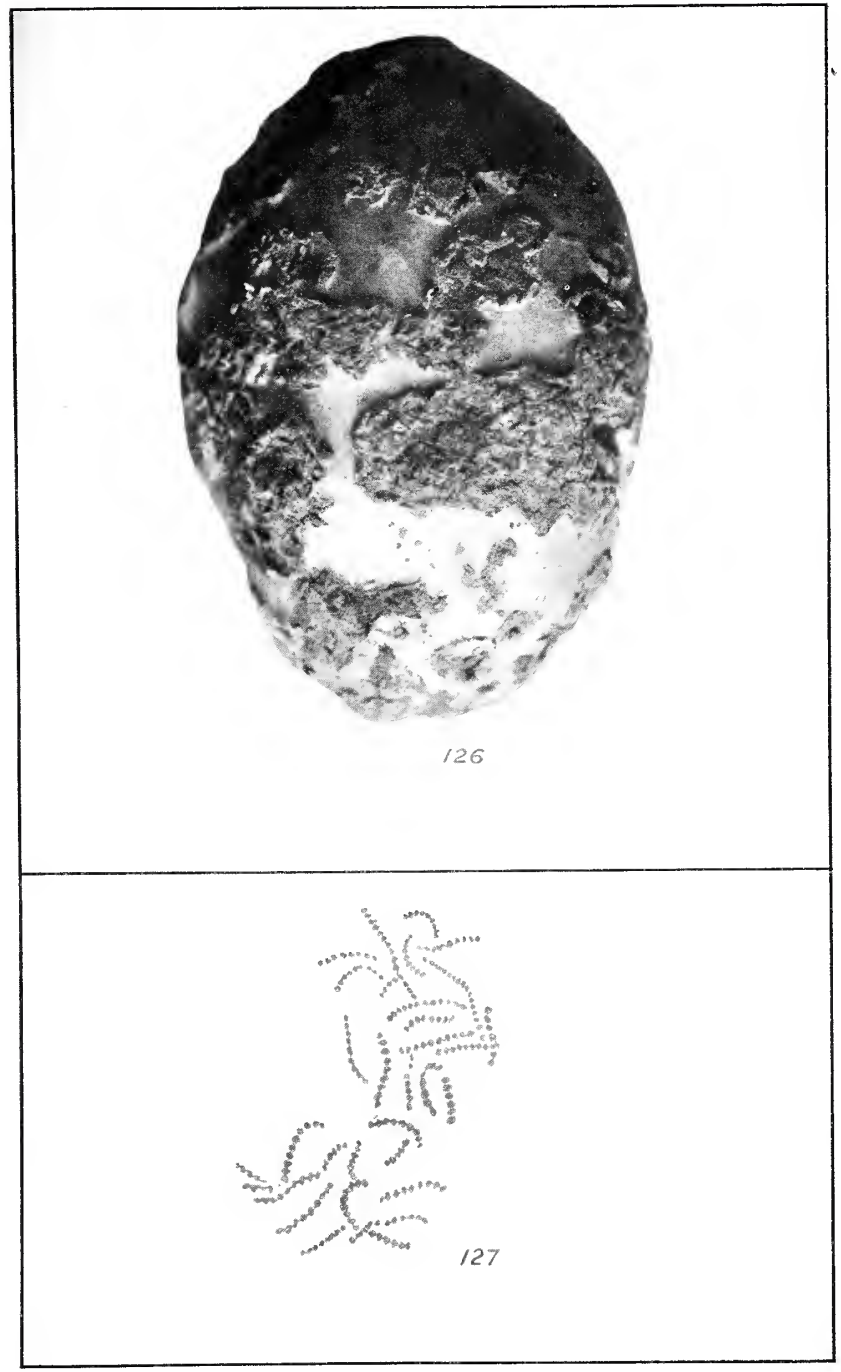




\section{PLLTE XLIV.}

$\triangle C A B$.

Fig.

128. "Scab" experimental plots at Bunyip seen from South, with min crop on either side.

129. Same plots seen from North side. 
Peate Xlit.

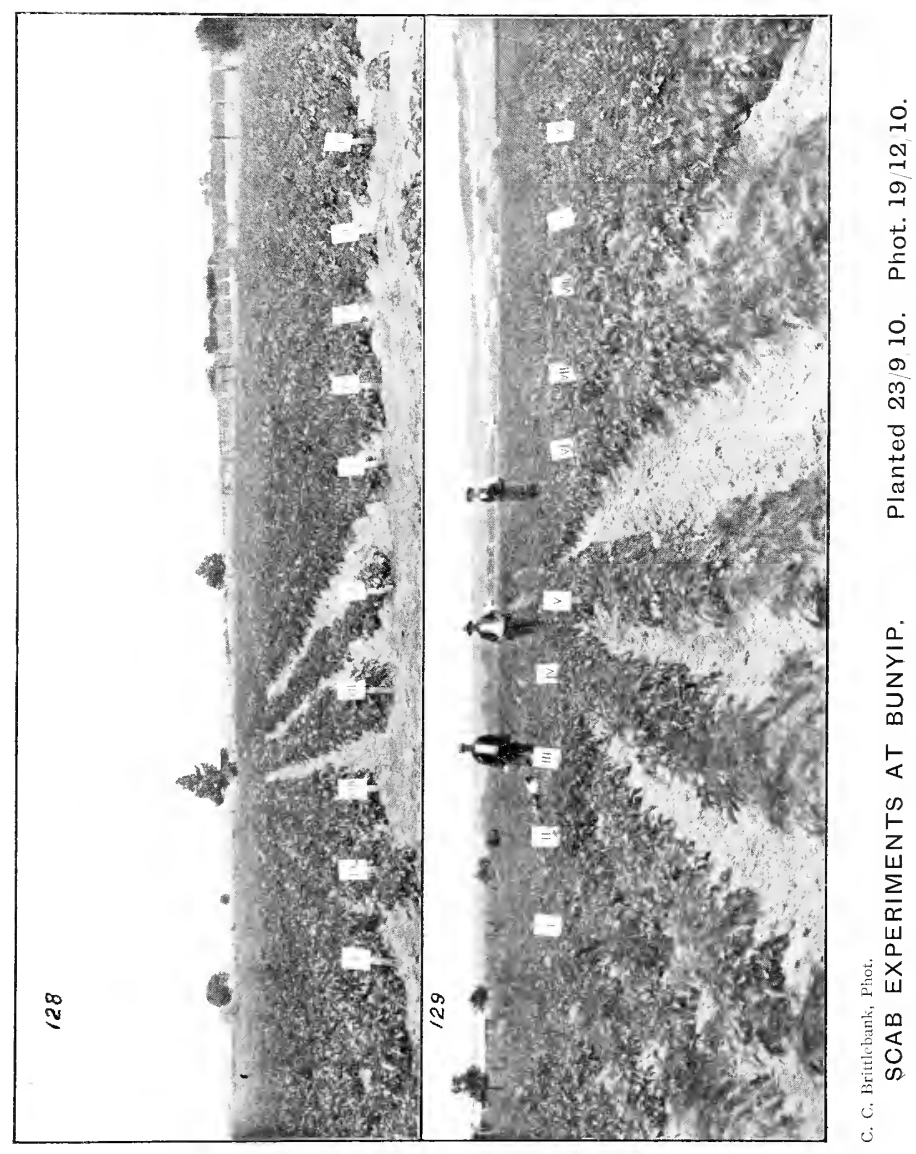





\section{PLATE XLY.}

Fig.

SCAB.

130. Produce of clean (I.) and scabby (II.) seed, steeped in Lime-water Bordeciux for quarter of an hour.

131. Produce of (tean (III.) and seabby (IV.) seed, steeped in Formalin for two hours.

132. Produce of clean (V.) and x(abby (V̌I.) seed, untreated.

133. Produce of clean (VII.) and scabby (VIII.) seed, steeped in Corrosive Sublim ste for two hours.

134. Produce of alean (IX.) and sabby (X.) seed, steeped in Bluestone solution for quater of an hour.

The brackets indicate smalls and seabby potatoes in each plot, and the result in the untreated scabby plot (VI.) is very marked. 


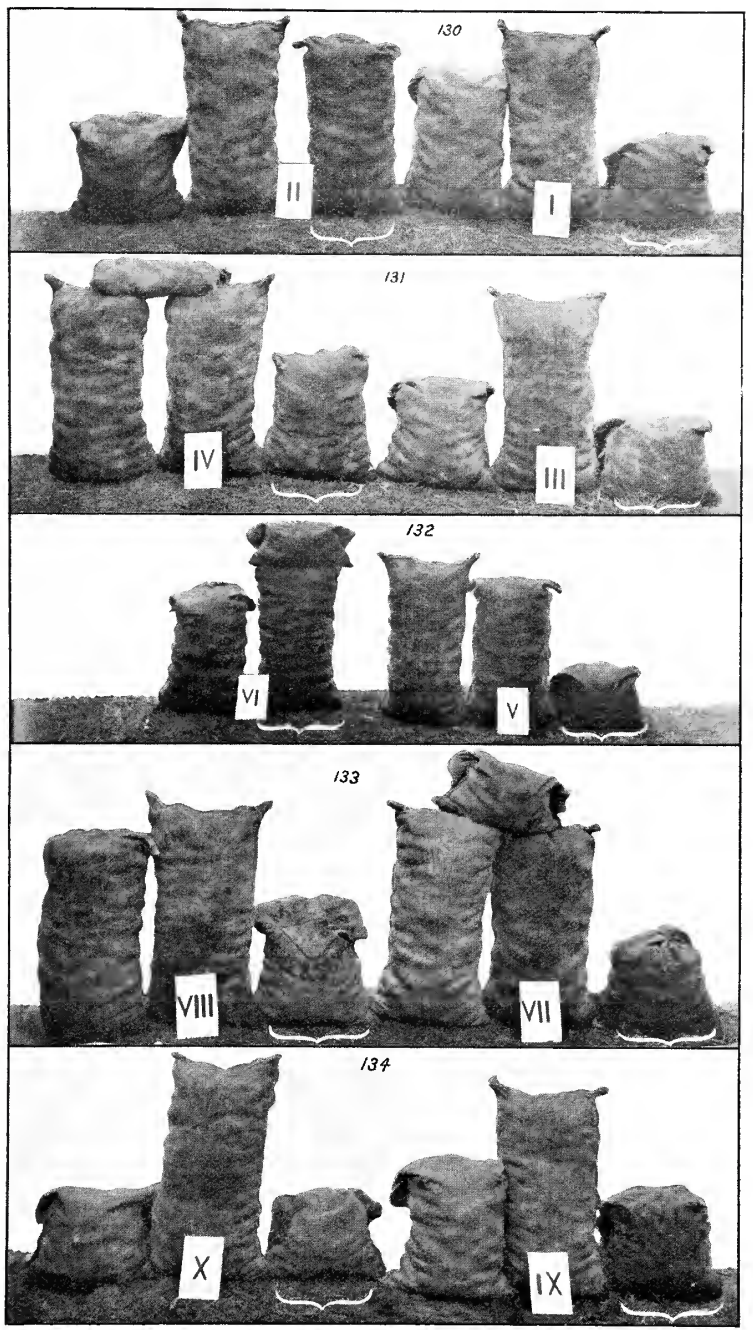

C. C. Brittlebank, Phot,

PRODUCE OF TEN PLOTS, SHOWING SMALLS AND SCABBY POTATOES ABOVE BRACKETS 




\section{PLATE XLNT.}

Fig.

BLACKLEG.

135. Potato plants with young leaves towards base discoloured and underground portions blackened. 


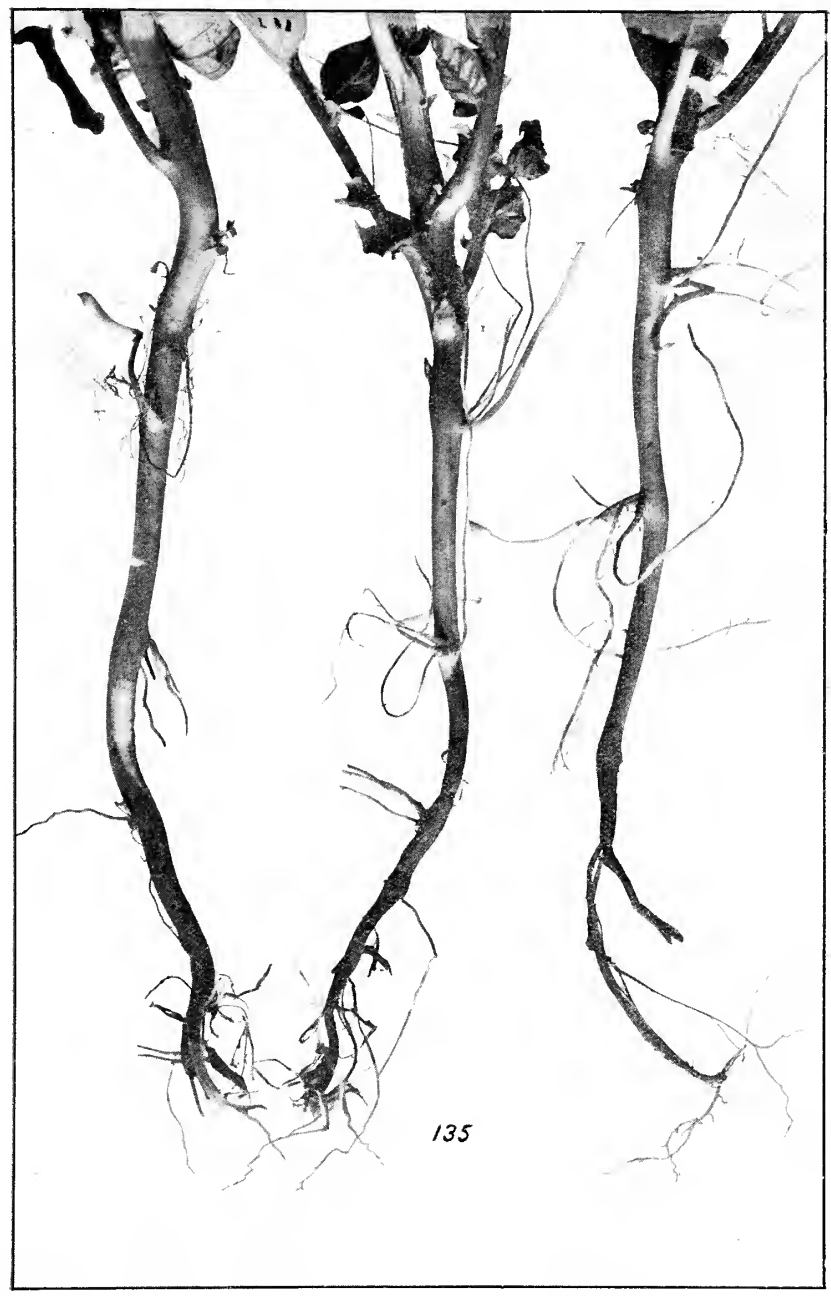

C. C. Brittlebank, Phot. 

PLATE XLVII.

lig.

BLACKLE:

131. Young tubers formed on plunt affected with Blackleg. 


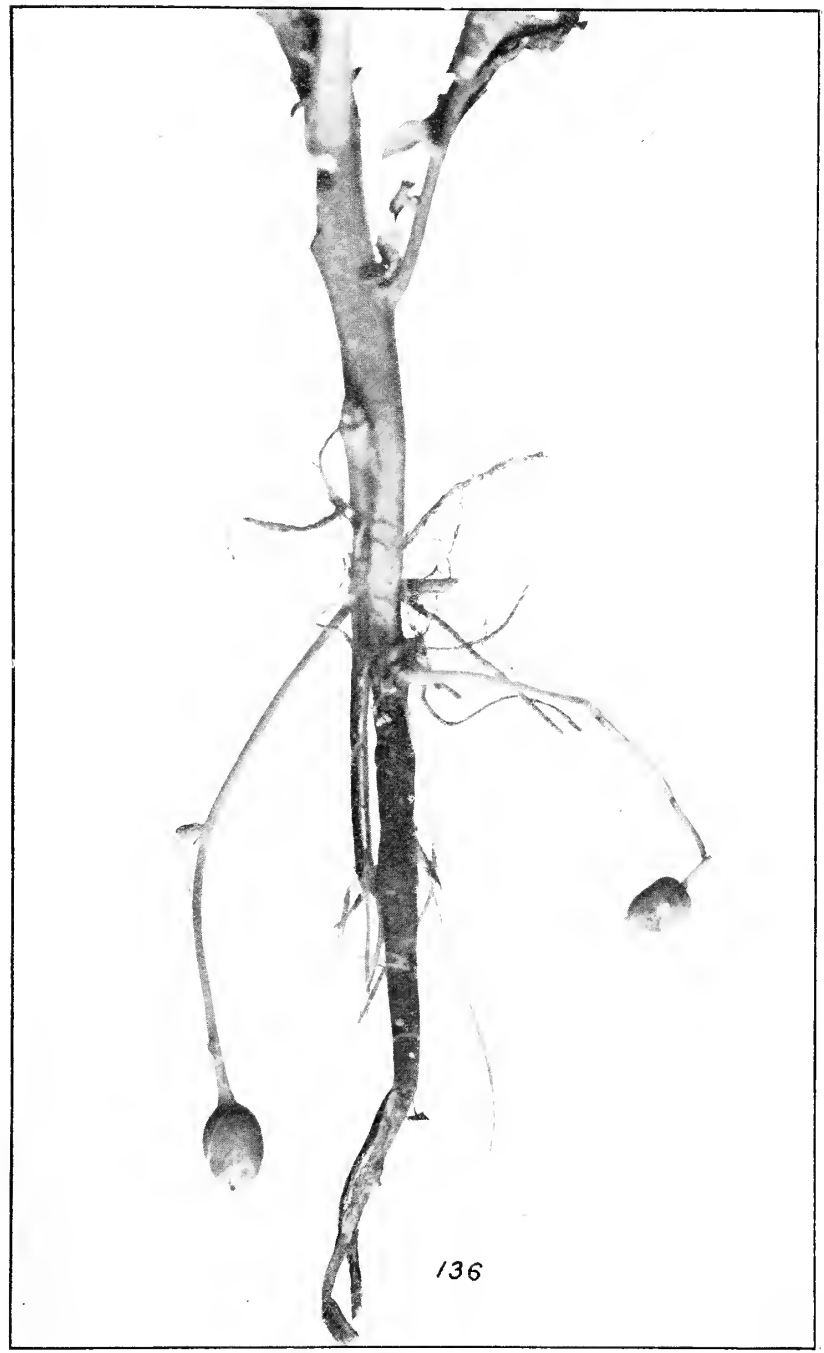

C. C Brittlebank, Phot. 




\section{PlTTE XIIIII.}

Fig.

\section{BLACK J)T DESEASE.}

137. Blakenod and britte tem covered with sckerotia above and below ground.

13s. Hollow st mom opened wh. showing development of sclerotia below surface of ground but not above it.

134. Ponio: of st:m showing patches with another fungus (Phoma), and morked on stem with $x$.

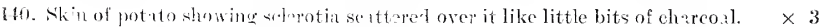


Plate XLVIII,

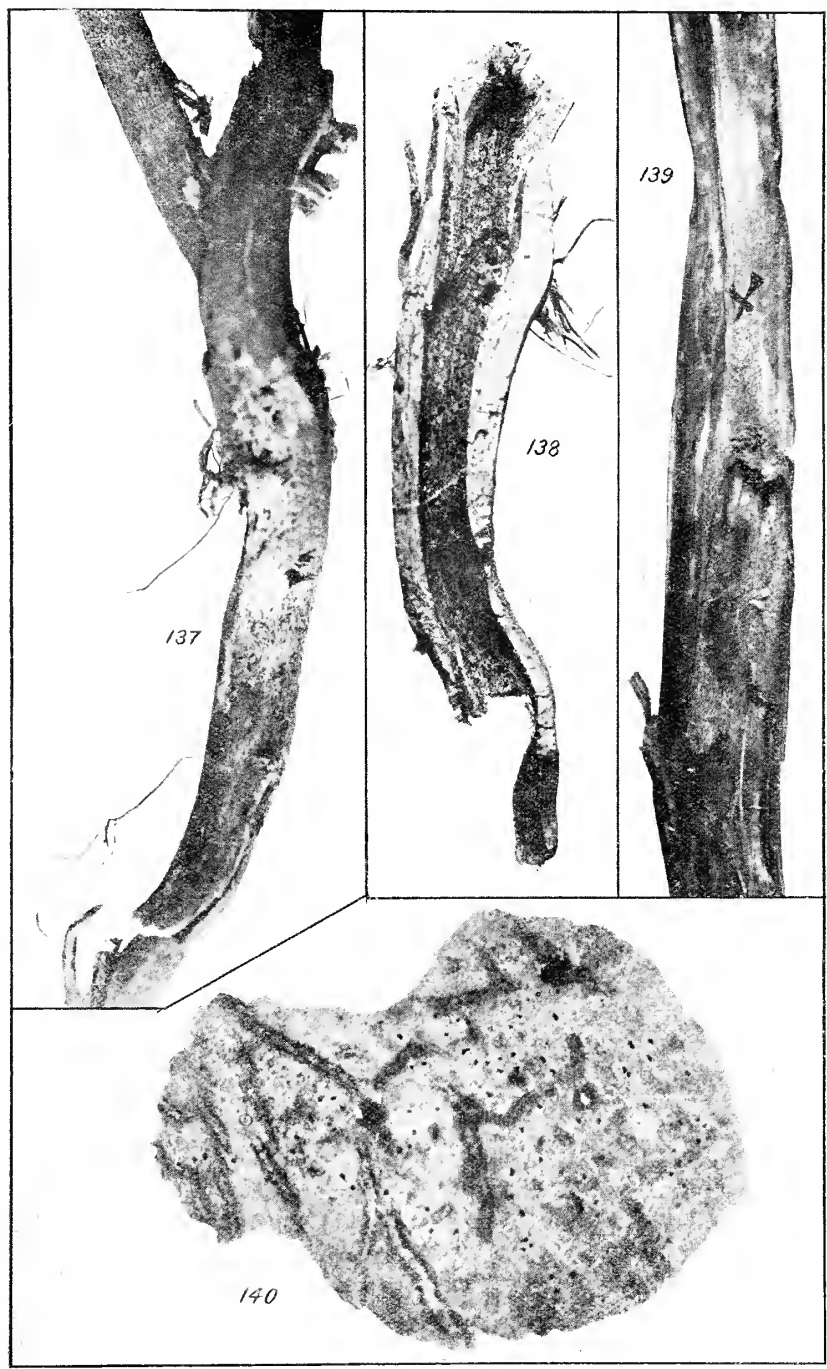

C. C. Brittlebank, Phot. 




\section{PLATE XLIX.}

Fig.

\section{BLACK DOT DISLASE.}

1tl. Surface of $x$ t:m. showing bluck dots densely crowded together $\ldots \quad \times 3$

142. Section showing white conidia att ached to short stalks at base of rigid hairs $\quad \times 250$

143. Seetion showing sclerotia bursting through skin ant some of them surmounted by $\begin{array}{llllllll}\text { rigid hizirs } \ldots & \ldots & \ldots & \ldots & \ldots & \ldots & \ldots & \times 80\end{array}$

14. Seetion showing selerotia surmonnted by hairs and producing eonidia .. $\quad \times 80$

14.). Sclerotia clevated above surface and immense production of eonidia at base of $\begin{array}{lllllllll}\text { huirs } & \ldots & \ldots & \ldots & \ldots & \ldots & \ldots & \ldots & \times 250\end{array}$

146. Advanced selerotia in section. densely covered with hairs and with colourless $\begin{array}{llllllllll}\text { routents } & . & \ldots & \ldots & \ldots & \ldots & \ldots & \ldots & \ldots & \times 250\end{array}$

147. Surface view of sclerotia, single or rum together $\quad \ldots \quad \ldots \quad \ldots \quad \ldots \quad \times \quad \times 250$ 
Piate MLIX.

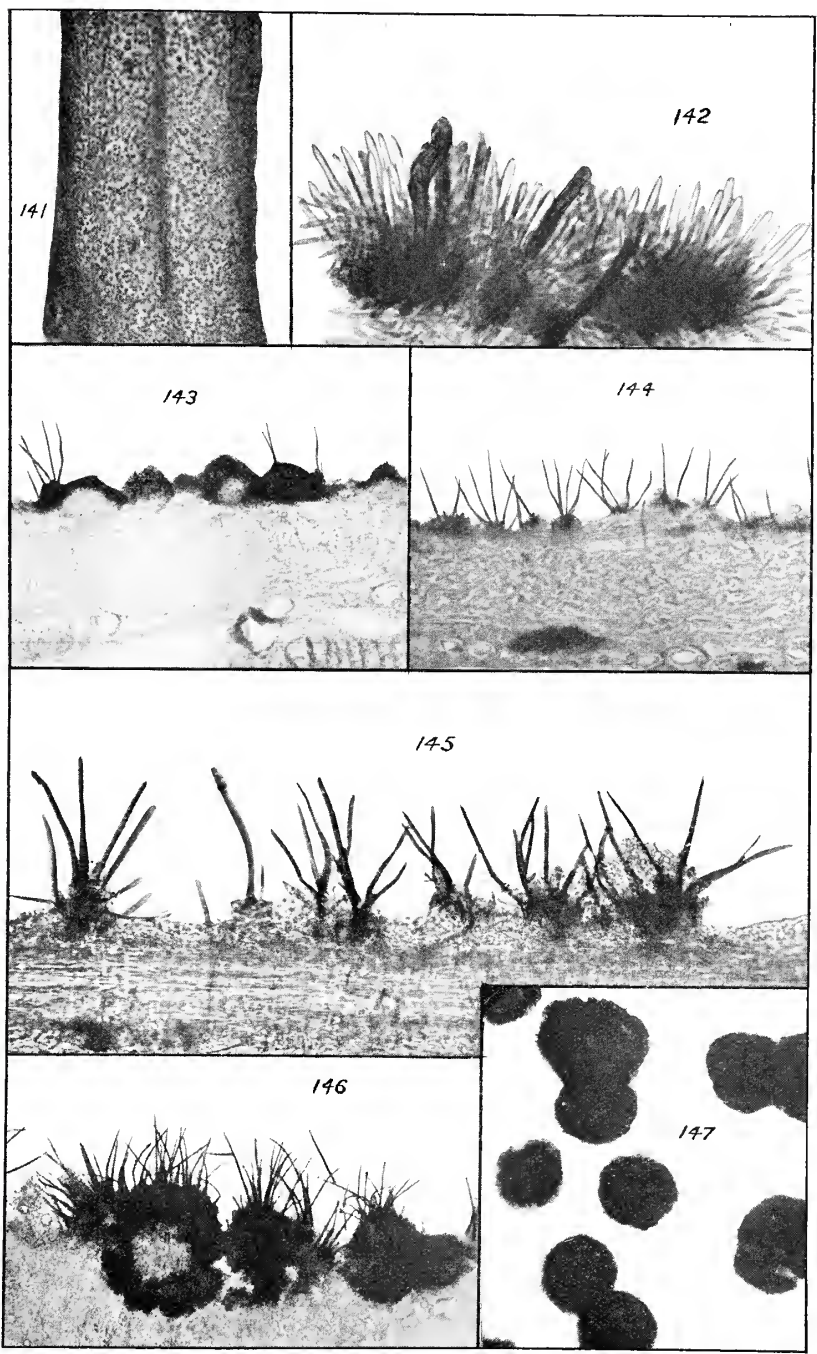

C. C. Brittlebank, Phot.

$\times 3,80$, and 250

BLACK DOT DISEASE, SHOWING NATURE OF FUNGUS 




\section{PLATE L.}

BROWN RIN(: THREADY EYE, AND LENTICELS.

Fig.

148. Section of vascular bundle from "Brown Ring" showing fungus filaments in the

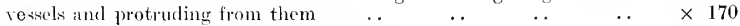

149. "Threndy eye" pot to pro lucing minute tubers from the "eyes" almost directly, which is a characteristic of the disease.

150. Lenticels excessively developed, slowing as raised whitish spots on tubers kept under moist conditions. 
Plate L.

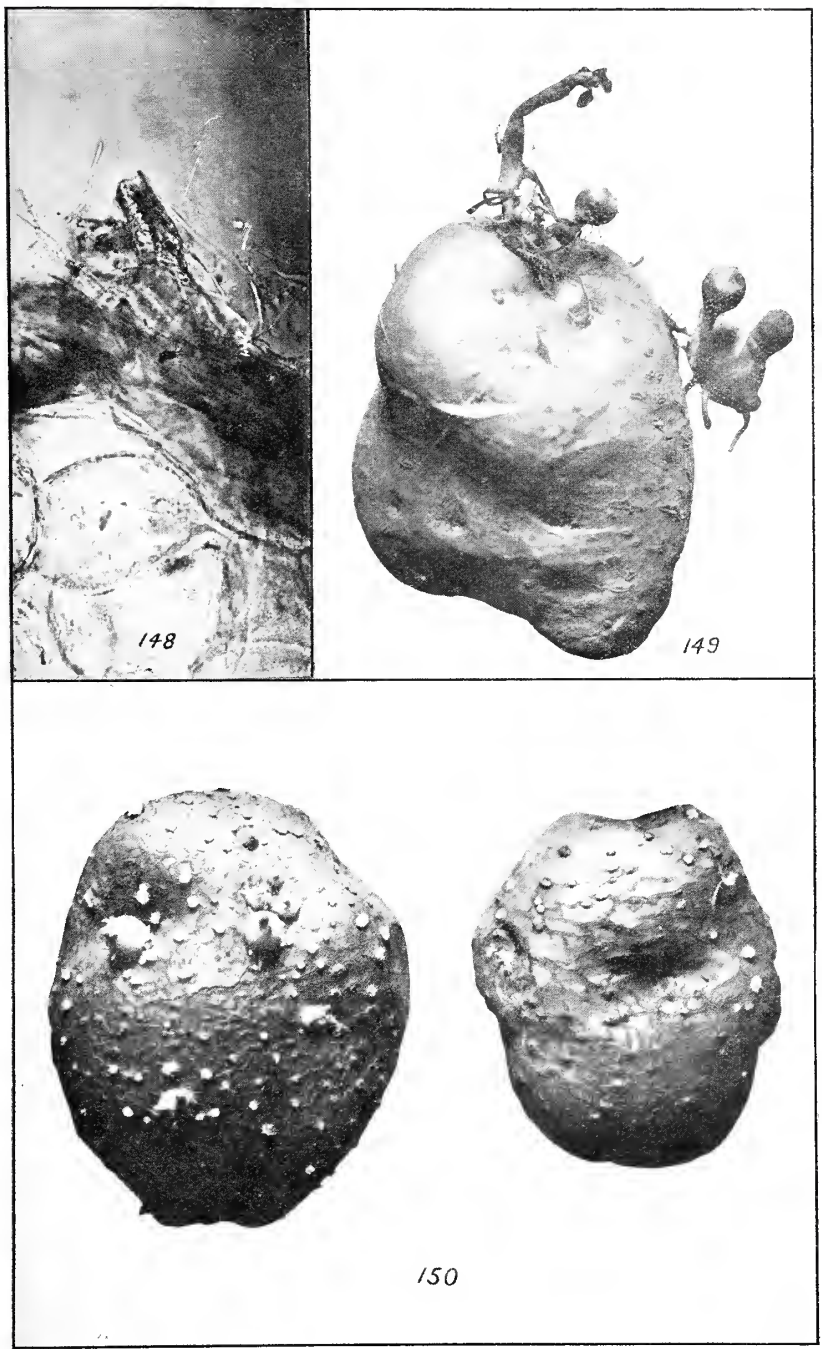

C. C. Brittlebank, Phot.

Nat. Size, $x 170$

BROWN RING, THREADY EYE, AND LENTICELS 



\section{APPENTIX I.}

\section{WEATHER CONDITIONS OIER VICTORIA FOR THE FIRST QUARTER OF 1911.}

January.-This month was characterized by rery equable temperatures over the whole State. In Melbourne the highest was 96.7 , on the 5th ; and the lowest, 51, on the 10th. The rains were mainly the result of the southward extension of monsoonal storms. and were almost confined to the eastern half of the State. The rainfall was generally in excess of the normal amount east from a line joining Echuca and Wilson's Promontory, and was very heavy in Gippland, most stations there receiving more than double the average amoint.

February.-Generally sultry and at times thundery weather continued over the whole State till the middle of the month, accompanied by phenomenally henry rains. Between the 5th and the 8th tremendous monsoonal rains foll over the Hallee and Wimmera Districts, and during the next few days extended to the rest of the State. Owing chiefly to this great storm the rainfall over Victoria was many times more than the average amount. The rest of the month was of normal character. Shade temperatures were even more equable than in Jamuary, the highest in Jlelbourne being $90 \cdot 3$. on the 8 th : the lowest, $52 \cdot 4$, on the 20 th.

IIarch. - This was another wet month. In the north the arerage was exceeded by about 30 per cent., but south of the Dividing Ringe two to three times the normal amount fell. The greatest excesses were in the ('entral south and in Gippsland, serelal stations in both areas receiving more than three tines the verage amount. This was almost entirely due to a slow-moving storm, whish produced from the 6th to the 8 th a serien of most violent thunderstorms accompanied by torrents of rain, which again and again flooded the streets of Nelbourne and feelong, and did much damage to bridges and crops.s in Gippsland. Another general rain fell about the 18 th and 19th. Rains which fell about the 13th and 14th, and from the 27th to the 30th, were confined mainly to southern areas. Temperatures were again very equable over the whole state. In Nelbourne, the highest shade reading was $88 \cdot 3$, on the 5 th ; and the lowest. $49 \cdot 1$, on the 20th.

Although heary monsoonal rain storms formed so marked a teature of the weather throughout the quarter, the arerage humidity of the air does not appear to have been above normal in Mclbourne. Inland there was probably some excest and especcially in the north-east.

The driest portion of the state was near the western border. Serviceton recording for the three months 285 points and Nekon 325. The hewiest rainfall was in Southern and Eastem Gippsland, Hurringower, a bout 1.5 miles N. E. of Orbost, recording no less than 32.1 inches, and Balook, a place 13 or 14 miles north of Alberton, 30 inches. Other heavy totals were, in Gippsland, Genoa, $26 \cdot 28$ inches; ('amn River, $25 \cdot 87$ inches: Walhalla, 23.87 inches; Gelantipy, 23.5t inches; and in the Cape otway Panges, Weeaproinah, $22 \cdot 52$ inches; and Johanna River, $22 \cdot 01$ inches.

The following tubles show the mean temperature compred with the normal, and the humiditics, at four typical stations in Victoria :-

\begin{tabular}{|c|c|c|c|c|c|}
\hline & $\cdots$ & & Jantiary. & Foluthays. & March. \\
\hline Melboume & $\left\{\begin{array}{l}\text { Nean Temperature } \\
\text { Normal Mean Temperature } \\
\text { Humidity.. } \\
\text { Normal Humidity ... }\end{array}\right.$ & $\begin{array}{l}\cdots \\
\cdots \\
\cdots \\
\cdots\end{array}$ & $\begin{array}{l}67 \cdot 7 \\
67 \cdot 5 \\
59 \\
64\end{array}$ & $\begin{array}{l}68 \cdot 3 \\
67 \cdot 2 \\
67.7 \\
6.5\end{array}$ & $\begin{array}{l}6.4 \cdot 4 \\
64 \cdot 7 \\
69 \\
67\end{array}$ \\
\hline Colae & $\left\{\begin{array}{l}\text { Mean Temperature } \\
\text { Norma? Mean Temperature }\end{array}\right.$ & $\begin{array}{l}\cdots \\
\cdots\end{array}$ & $\begin{array}{l}6.7 \cdot 7 \\
6.5 \cdot 1\end{array}$ & $\begin{array}{l}6.5 \cdot 8 \\
6.5 \cdot 7\end{array}$ & $62 \cdot 2$ \\
\hline Mildura $\ldots$ & $\left\{\begin{array}{l}\text { Mean Temperature } \\
\text { Normal Mean Temperature } \\
\text { Humidity.. }\end{array}\right.$ & $\begin{array}{l}\cdots \\
\cdots \\
\cdots\end{array}$ & $\begin{array}{l}74 \cdot 8 \\
77 \cdot 1 \\
44\end{array}$ & $\begin{array}{c}69 \cdot 9 \\
77 \cdot 6 \\
58\end{array}$ & $\begin{array}{l}67 \cdot 6 \\
70 \cdot 0 \\
53\end{array}$ \\
\hline Butherglen & $\left\{\begin{array}{l}\text { Mean Temperature } \\
\text { Normai Mean Temperature } \\
\text { Humidity. } \\
\text { Normal Humidity... }\end{array}\right.$ & $\begin{array}{l}\cdots \\
\cdots \\
\cdots \\
\cdots\end{array}$ & $\begin{array}{l}73 \cdot 7 \\
75 \cdot 0 \\
50 \\
10\end{array}$ & $\begin{array}{l}71 \cdot 8 \\
75 \cdot 8 \\
63 \\
42\end{array}$ & $\begin{array}{l}6.5 \cdot 7 \\
69 \cdot 5 \\
6.5 \\
5.5\end{array}$ \\
\hline
\end{tabular}




\section{REGTLATONG RELATING TO POTATO DISEASES-COMAONWEALTH}

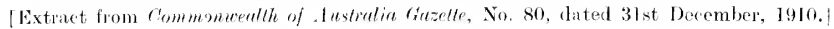

\section{Prociatutitor}

('ommonwealth of Australiat (o) wit.

I)(T), (iovernor-cinomit.

By His Exceslency the Right Honorable William Humble, Wall of Dudkey, a member of His Majosty"is Most Honorable Privy ('ouncil, Kuight Grand (ross of the Most Distinguished Order of Saint Wichat and simt George, Knight Giand ('ross of the Royal Victorian Order, Governol-General and ('omminder in Chief of the ('ommonwealth of Australiat.

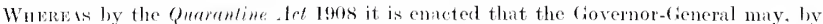
proclamation, prohifit the importation into Australia of anv animats or plants or parts of animals or plants, and that the power of prohibition shafl extend to prohibition generally or with limitetions as to place and subject-matter, and either absolutely or subject to any specified conditions or restrictions: And whereas by a prockamation published in the dinzelle of loth July, 1909, among other things the importation into Australia o" potatocs from Europe. New Zealand, Norfolk Island, and from any other country was prohibitad unless the (hiof Quarantine Officel were satisfied that the disease coused by Pleytophlitere infestans was not existent in the country from which they were exported': And whereas it is desirable to alter the conditions under which potatoes may be imported into Austrulia: Now therefore I, William Humble, Wat of Dudley, the Governor-

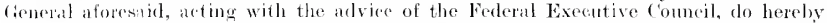
repeal paragraph (e) of ('lause 9 of the suid proclamation and do hereloy prohibit the importation of potatoes from any country unless-

1. They are accompanied by an official certitiente dated and signed by a responsiber oflices of in forernment Department of the country of origin. identifying the potatoes, specifying the quantity, and rertifying-

(11) that they were free from the suid disease at the date of the issue of the certificate;

(b) that they were grown in the country named:

(c) that they were grown at least 20 miles from any place known, after due investi. gation, to be or to have been within five years infected with the said disease;

(d) that they were packed in the comntry of origin in clean new packages:

2. The bags, crates, or other packages containing the potatoes are marked on the outside with the name of the country of origin and with other distinguishing mark or makks:

3. The potatoes, after being landed, are planted in quarantine in an approved place, and, after having matured, are, with the product of their eultivation, found, on inspection, to be free from disense:

4. The importer enters into a bond in the sum of 250 eonditioned that he will pay the cost of inspeetion of the protatoes and of super vision, that the potatoes and any parts thereof and any crop produced therefrom shall not be dug or removed from the approved plaee without the written permission of the (hief Quarantine Officer, and that he will give written notice of not less than one week to the Chief Quarantine Officer of his desire to dig the potatoes.

Provided that the Minister may permit potatoes whieh are eertified by a Quarantine Officer to be free from disease to be imported under and subject to such eonditions as the Minister may think fit to impose, for lise as food.

Given under my hand and the Great Scal of the Commonwealth this 22nd day of December, in the year One thousand nine hundred and ten, and in the first year of His Majesty's reign.

By His Excelleney's Command, 
[Extraet from Commonwentth of Australia Gazette, No. 58, dated 29th July, 1911.]

\section{Procthatator}

Commonwealth of

Alistralia

to wit.

DudLev,
By His Excellency the Right Honorable William Humble, Earl of Dudley, a Member of His Najesty's Most Honorable Privy ('ouncil, Kinight Grand ('ross of the Most Distinguished Order of Saint Nichnel and Saint George, Knight Grand Cross of the Royal Vietorian Order, Governor-General and Commander-in-('hief of the ('ommonwealth of Australia.

WHEREs by the Qumantine fot 1908 it is enacted that the Govemor-(ieneral may, by proelamation, prohibit the importation into Australia of any animals or plants, or parts of animals or plints, and that the power of prohibition shall extend to prohibition generally, or with limitations as to place and subject-matter, and either absolutely or subject to any speeified eonditions or restrictions: And whereas by a prockmation published in the Guzette of 25 th Nareh, 1911 , the importation of potatoes into Anstralia was prolnibited mless certain conditions were eomplied with: And whereas it is desirable to amend the said prochmation: Now therefore I, William Humble, Earl of Dudley, the GovernorGeneral afores:id, acting with the advice of the Federal Executive council, do hereby repeal the sid Proclamation and I do hereby prohibit the importation of potatoes from any country unless-

1. They are aceompanied by an official certificate, dated and signed by a responsible officer of a Government Department of the country of origin, identifying the potatoes, specifying the quantity, and certifying-

(a) that at the date of the issue of the certifiente they were, on inspection, found free from the disease caused by Phytophthore infestans (known as Irist Blight), and from the disease Synchytrizm endobioticum (known as potato canker, bluck scab, warty disease, and cnuliflower disease in potatoes)

(b) that they were grown in the eountry named;

(c) that they were grown on premises known, after due investigation, not to be or to have been during the preeeding twelve months infected with either of the said discases;

(d) that they were paeked in the country of origin in clean new packages.

2. The bags, crates, or other packages eontaining the potatoes are marked on the outside with the name of the country of origin and with other distinguishing mark or marks:

Provided that the Minister may permit potatoes which are eertified by a Quarantine Offieer to be free from disease to be imported under and subject to such eonditions as the Minister may think fit to impose.

Given under my hand and the Great Seal of the Commonwealth this 20th day of July, One thousand nine hundred and eleren, and in the second year of His Iajesty's reign.

By His Exeelleney's Command, 


\section{REGULATTONS RELATING TO POTATO JISEASES, - STATE OF VICTORIA.}

[Extract from the Jictorin Government Gazelte of 5th July, 1911, pu, 3455-6.]

Vegetation Diseases Acts.

REGLLATIONS UNDER THE VEGETATION DISEASES ACTS.

At the Exrerutive Council Chamber, Jelbourne, the thirtieth day of June, 1911.

Present :

Mr. Writt

Mr. Brown

Mr. Ma Kenzie

His Excellency the Governor of Victoria.

Mr. Billson

Mr. Hagelthorn.

UNDER the powers in that behalf conferred by the Vegetation Diseases Acts to make regulations, among others, for the purpose of regulating the importation, introduction, or bringing in to Fic toria of any particular kind of tree, plant, or vegetable, likely in the opinion of the Governor in Council to spread any disease or insect, and for preseribing penalties for the breach of any regulations so made, the Governor of the State of Victoria, by and with the andice of the Executive Council, doth order as follows:--

General.

1. The Regulations of the 16 th day of Angust, 1910, and published in the Government Grzette of the 24 th day of August, 1910 , shall be and the same are hereby repealed.

\section{Interpretwion.}

2. For the purpose of these Rocrulations -

("i) "Registered murk or brand" means any mark or brand registered with and approved by the Depurtment of Agriculture of the State or territory of
exportition. (b) "Insprector" means an inspertor appointed in aceordance with the provisions
of the Veget ition Diseases Acts.

\section{Inpratalion of Trees, Plants, and Tegetrables Generrilly.}

3. All importers of trees, plints, or veget bliss, the importation, introduction, or bringing into Victorin of which is for the time being pohibited, cxcept subject to regulations, not being of a kind in respect to which any other specifie regulation or regulations is or the for the time being in force. must give notice to the inspector under the Vegetation Diseases Act upon arrival of any trees, plantw, or vegetables before the removal of sucle trees, plants, or vegetilles from any dock, pier, wharf, station, or other place where such trees, plants, or veget thles have been landed.

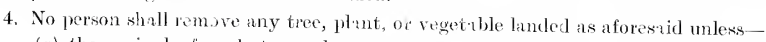

(a) the arrival of such tree, plant. Or vegetable has been duly notified to the inspector, and a certifieate or written authority of removal has been obtrined
from him;

(b) each case, crate, bag, bundle, or other package entaining nursery stock, trees, jlants, or vegetibles, and cach bmeh of bananas has indelibly and legibly printed, maked, stencilled, or impressed upon it, or mpon a label, a ticket or tag att ached thereto the grower's or exporter's name and address, or his regist red mark or brand, in letters or figures of not less than one-half inch
in length;

(c) the package cont zining the said tree, plant, or vegetable is new.

5. All discased trees, plints, or vegetables shall be dealt with in accordance with the Act at the expense of the import.r.

\section{Importation of Polatoes and Tomatoes.}

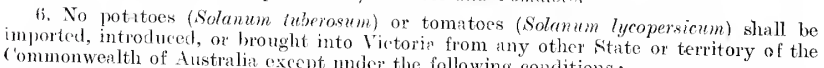
('ommonwealth of Australia except nnder the following conditions :-

(16.) That the arrival of such potitoes or tomatoes has been duly notified to an inspector, and a writton certifiente or written authoricy of removal has been
obtained from an inspector. 
(b) That they are accompanied by a certificate in the form in Schedule $A$ of these Regulations.

(c) That they are packed in new bags or other new packages, branded with the name and address of the grower.

(d) That all such potatoes or tomatoes aforesaid are forwarded through the port of Melbourne or other places as may be approved from time to time by the Minister of Agriculture for the Strate of Victoria.

All such potatoes or tomatoes aforestid imported under the conditions afores id shall be again inspected in Melbourne, or other approved place of entry, by an inspector of the Victorian Department of Agriculture, and if found to be free from Irish Blight (Phytophthora injestans) and other proclicimed diseases may be removed therefrom on payment of inspection fees as prescribed.

If, on inspection, any prekage is found to cont in diseased potatoes or tomatoes, such package and its contents shall be refused admission into Victoria, but the contents of such package may be sorted under the supervision of an inspector under the following conditions, viz. :-

(a) Such package, with its contents, shall be taken forthwith from the place of inspection to any place approved by the inspector;

(b) when sorted, potrtoes or tomatoes which are found by the inspector to be free from disease shall be re-packed in new packages, and may be permitted entry ;

(c) all potatoes or tomatoes which, after sorting, are found by the inspector to be diseased, shall, at the importer's or consignee's expense and under the supervision of an inspector, be destroyed in such manner as the inspector may direct.

\section{Importation of Stightly Diseased Fruit.}

7. Fruit which is found, on inspection, to be slightly diseased, may be imported into Victoria from any other State or territory of the commonwealth of Australia for manufacturing purposes only by bona fide fruit preservers under the following conlitions, viz: -

(a) Such fruit shall be inspected by an inspector, and may be rejected.

(b) If passed by the inspector such fruit shall be taken forthwith to any fruitpreserving factory approved by the inspector, and there manufactured; the refuse of all such fruit shall be absolutely destroyed in such manner as the inspector may direct. All receptacles in which such fruit has been carried shall forthwith be either destroyed by fire or otherwise treated at the factory to destroy all fruit diseases to the satisfaction of an officer of the Department of Agriculture.

(c) No such fruit shall be sold or distributed unless in a manufactured state,

8. If, on inspection, any package is found to contain a proportion of fruit which is sound and free from disease, and also fruit which is slightly diseased, the contents of such package may be sorted under the supervision of an inspector under the following conditions :-

(a) Such package, with its contents, may be taken forthwith from the place of inspection to any place approved by the inspector;

(b) when sorted, fruit which is free from disease may be re-packed in clean packages and permitted entry, and slightly-diseased fruit may be disposed of to the fruit preservers subject to all the conditions contained in Regulation 6.

All fruit which, after sorting, shall be deemed by the inspector to be unfit by reason of disease for the purpose of manufacture or sale, shall, at the importer's or consignee's expense and under the supervision of an inspector, be destroyed in such manner as the inspector may direct.

\section{Penalties.}

9. Any person who shall be guilty of a breach of or who shall fail to comply with these Regulations, shall be liable to a penalty, for the first offence not exeeeding Ons pound, and for any subsequent offence not exceeding Ten pounds. 


\section{SCHEDI'LE A.}

\section{INSPECTOR'S CERTIFICATE.}

I hereby certify that I have duly inspected the above-mentioned* and have found them to be, to the best of my knowledge, clean and free from Irish Blight in any stage of development, and from any other*

Doted at

$$
\text { this }
$$

Signature of officer of

official desiguation -

Address -

\footnotetext{
* Sitite whether potatoes or tom itoes.
}

And the Honorable George Graham. His Mnjesty's Minister of Agriculture for the St te of Victoria, shall give the necessary directions herein accordingly.

\section{F. W. IABBBOTT.}

('lerk of the Executive Council.

[Extract from the Victoria Crocernment Gazette of 5th July, 1911, pp. 3456-7.]

I'egetation Diseases Act 1896.

\section{REGLLATIONS AUTHORIZING AND REQUIRLNG INSPECTORS TO CHARGE FEE AND EXPENSES.}

At the Executive Council. Chamber, Helbourne, this thirtieth day of June, 1911.

\section{Present :}

His Excellency the Governor of Vietoria,
Mr. Watt
Mr. Brown
Mr. Mr.Kenzi .

Mr. Billson

Mr. Hagelthorn.

UxDen the powers in that behalf conferred by the Tegetation Diseases Act 1906, to m rke regulations authorizing and requiring inspectors to charge fees and expenses in respect to certain matters, the (tovernor of the Strte of Victoria, by and with the advice of the Exceutive Council, doth order as follows:-

1. The Regulations of the 7 th day of May, 1907 ; of the 10th day of September, 1907 : of the 18th day of February, 1908; of the 18th day of August, 1908; of the 18th day of January, 1909; and of the 15th day of June, 1909, shall be and the same are hereby repealed.

2. The fees and expenses authorized and required to be charged by inspectors under the provisions of seetion 8 of the Vegetation Diseases Act 1906 shall be as follows:-

$$
\text { A.-Inspection Fees. }
$$

For examining the underst ated trees, vegetıbles, or fruits imported, introduced, or brought into Victoria :-

Banana fruits-

For erch bunch, One halfpenny.

For each ease or crate, per bushel or portion thereof, One halfpenny.

Pineapples -

For eacli case or crate, per bushel or portion thereof, One halfpenny.

Fruit (other than bananas and pineapples) -

For each ease, per bushel or portion thereof, One halfpenny.

Melons--

For each dozen or portion thereof, One penny.

Cucumbers, tomatoes, and chillies-

For each bushel or portion thereof, One halfpenny.

Cauliflowers and cabbages-

For every 5 cwt. or portion thereof (in crates or in bulk), Twopence.

Potatoes--

For every ton of 15 bags or portion thereof, Sixpence.

Vegetables (not elsewhere ineluded) -

For every ten bags or eases or portion thereof (the total weight of ten bags or cases not to exceed one ton), Threepence. 
Australian-grown peas--

For each sack or portion thereof up to 100 sacks, One halfpenny.

For every additional twenty szeks or portion thereof. Threepence.

Rice-

For every ten sacks or portion thereof, Three halfpence.

Plants, bulbs, corms, tubers, and rhizomes (not elsewhere included)-

For every owt, or under, sixpence.

Over 1 cwt., but not exeeeding 1 ewt., One shilling and sixpence.

Nuts-

For every cwt. or part thereof, One peuny.

Notwithstanding anything to the eontrary cont aned in these Regulations, the minimum charge for any single inspection sliall be Threepence.

$$
\text { B.-Sorting Fees. }
$$

For examining during the sorting of each case of fruit imported, introduced, or brought into Vietoriz and rejected for fruit fly or any dimease:-

Threepence per case, in addition to the inspection fee.

For examining during the sorting of each 'wt. or portion of each cwt. of fruits, onions, potatoes, and other veget?bles contrined in sacks or bags, imported, introduced, or brought into Virtoris and rejected for disease :-

Ninepence per cwt. or portion thereof, in addition to the inspection fee.

$$
\text { C.-Fees for Treatment of Trees, Plants, or Tegetables. }
$$

For fumigating fruit:-

For each case or package not exceeding I Imperial bushet in capacity, one penny.

For each case or package exceeding 1 Imprerial bushel in capacity, Twopence.

For fumigating or otherwive treating nursery stock, trees, plants, cuttings, or bulbs:-

For each package 1 cwt. or under, Two shillings.

For each paekage over 1 cut, and not exeeding 2 cwt., Three shillings.

For ench packnge over 2 cwt. and not exceeding 3 ewt., Four shillings.

For each package exceeding 3 cwt., Four shillings, phus One shilling for each additional cwt. or part thereof over 3 cwt.

For fumigating grain contained in packages not exceeding l Imperial bushel in capacity :-

For quantities not exceeding 100 packages. Threepence for every 10 packages or part thereof.

For quantities exceeding 100 packages but not exceeling 500. Twopence for every 10 prekages or part thereof.

For quantities exceeding 500 packages, Three laalf-pence for ever'y 10 packages or part thereof.

For fumigating grain conta ined in packages exceeding 1 Imperial bushel in capacity :-

For guantities not exceeding I00 packages, Sixpence for every 10 packages or part thereof.

For quantities exceeding 100 packages but not exeeding 500 , Fourpence for every 10 packages or part thereof.

For quantities exceeding 500 packages, Threepence for every 10 packages or part thereof.

Notwithstanding anything to the contrary contrined in these Regulations, a minimum charge of Two shillings shall be made for the fumigation of such packages.

$$
\text { D. - Fees for Treatment of Cases and Packayes. }
$$

For dipping or treating eases or other packages containing, or intended to contain, nursery stoek, trees, plants, vegetables, or fruit:-

For each case or package not exceeding 1 bushel in capacity, One halfpenny.

For each case or package exeeding 1 bushel in capacity, One penny.

For each sack or bag of any capacity, One halfpenny,

Notwithstanding anything to the eontrary contained in these Regnlations, a minimum charge of Two shillings and sixpence shall be made for the dipping or treatment of such sacks, bags, or other paekages.

3. Such fees and expenses shall be paid to the inspector by the owner or consignee or person in possession prior to delivery of such trees, plants, vegetables, cases, or packages.

And the Honorable George Graham, His Majesty's Minister of Agriculture for the State of Victoria, shall give the necessary direetions hercin accordingly.

\section{F. W. MABBO'TT,}

Clerk of the Executive ('ouncil. 
[Extract from the Victoria Government Grazete of 2nd August, 1911, pp. 3987-8.]

Vegetation Diseases Acts.

REGULATIONS CNDER THE VEGETATION DISEASES ACTS REGARDING
THE TRANSFER OR RENOVAL WITHIN VICTORIA OF POTATOES.

At the Execution council rhomber, Meliowne, the twenty-eighth day of July, 1911.

PRESHNT :

His Exellency the Cinvenor of Victorin.

Mr. Billson

Mr. Thomsing

Ir. Hagelthorn.

Wherlas the Governor in ('ouncil is enrowered by the Vegetation I)iseases Acts to make regulations regarling the tansfer or removal within Victoria of any particular kind of tree, plant, or veget ible likely in the opinion of the Governor in ('ouncil to spread any disease or inseret: And whereas the Governor in ('omed is of opinion that the potato is a vegetuble likely to sprend disease: And whereas the Governor in council has by Proclamation in the Gorermment Gísefte prohibited, subject to Regulations, the bringing of potatoes into any portion of Victoria from certain other parts of Victoria specified in such Proclamestion, and hereinafter (tosether with any further parts of Victoria which may herepter le likewise pro(damed) referred to as "Potato Insjection Districts" : Now the forernor of the stite of Victoria, ly and with the advice of the Executive council, doth make the following Regulations:-

1. The Regulations made muler the sajel Aet on the 13th day of January, 1911, are hedeliy requealed.

\section{Interpretation.}

2. For the purposes of these Reguletions-

"Inspector" means an inspector appointed in accordunce with the provisions of the Veret tion joisenses Acts.

"Registred Mark" means any mak regintered with and approved by the Department of tericulture.

\section{('oncerning Potato In:section I)istricts.}

3. No proson shill remove or cause to be removed any potatoes from any Potato Inspection birtrict by rail or boat or otherwise unless-

(a) such potatoes shall have been, not more than fou days prior to such removal, examined by the hnspector and found to the best of his lnowledge and belief to be clean, free from Irish Blight (Phytophlora infestans), and reasonably free from other diseases of potatoes proclaimed under section 2, Act 1432 ;

(b) such potitoes are contained in bags, cases, or packages determined by the Inspector as sound, suitable, and clean;

(r) the bags, cases, or packages in which such potatoes are contained shall be legibly branded or st imped with the name and address (or registered mark) of the actual giower of such potatoes, and in the ease of previously-used bags, cases or packages, all other names and marks (if any) shall have been effectively obliterated; and

(d) a "Transport Permit" in the form of Schedule A hereto shall have been issued in respect of such potatoes by the Inspector and to the proper railway or boat official for attachment to the waybill or bill of lading as authority for the transport of such potatoes.

\section{Concerning Transfers within Potato Inspection Districts.}

4. Notwithstanding anything contrined in these Regulations an Inspector may examine any potatoes consigned from any place within any Potato Inspection District to any city or town situated within such district, and provided that all the conditions of these R egulations are complied with, may issue a "Removal Permit" as hereinunder provided in respect of such potatoes, without which such removal of such potatoes will eonstitute an offence under these Regulations. 
Concerning other than Polato Inspection Districts.

5. In other than Potato Inspection Districts any Inspector, when anthorized by the Minister of Agrieulture, may examine any potatoes at any railway station, wharf, warehouse, store, market, or other place.

6. No person to whom any potatoes sh $\mathrm{bll}$ be consigned from any part of Victoria (other than a "Pot ito Inspection District") to any other part of Victoria within 10 miles of any place where an Inspretor shull be stationed, shall remove any such pot itoes from any ralway station or wharf, warehouse, store, market, or other place unless-

(a) such potatoes shall have been, not more than four days prior to such removal, examined by the Insprector', and found to the best of his knowledge and belief to be clean, free from Irish Blight (Phytophthore infestans), and reasonably free from other disesses of potatoen proclaimed under section 2 , Act 1432 ;

(b) such potitoes are contrined in bags, cases, or puckuges detamined by the Inspector as sound, suitzble, and clean.

(c) the bags, caser, or packages in which such potrtocs are contuned shall be legibly branded or strmped with the name and address (or registered mark) of the actual arower of such potitoes, and in the chse of previously-unsed bags, cases, or packiges, all other names and muks (if any) shall hove been effectively obliterated; and

(d) a "Removal Permit" in the form of kededule B shall have been tissued in respect of such potitoes.

\section{Sintive.}

7. Potatoes found upon examination by an Inspector' to comprise a proportion of potatoes which are diseased shall be removed by the owner or consignee or asent of either to a place approved by the Finspetor, which may be the owner's store. and there sorted under his supervision, and dealt with under the following conditiont, viz. :-

(a) When sorted, all potstoes which are free from disentso my be repacked in bags, cases, or packages determined as sound, suit-1hle. nd clean, by the Inspector, who my then issue for such potatoes a "Removal Permit" in the form in sehedule $\mathrm{B}$.

(b) After sorting, all diseased pot itoes shall be destroyed or otherwise dealt with as the Inspector my direct.

(e) All expenses in connexion with the supervision, handling. sorting, eartage, and destruction of such potitoes shall be paid by the owner or consignee or agent of either.

\section{Chetiges.}

8. The charge for inspeetion shall be sixpence per ton or fraction of a ton, and shall be paid in respect to each lot or consignment prior to the issue of a "'Transport Permit" or "Removal Permit," as the case may be ; except in cases where the owner or consignee shall have lodged a deposit in money or approved gur rintee to cover all consignments to be submitted during a period of one month, when and in such cases the charge shall be calculated in respect of the aggregate tommage of potatoes submitted for inspection during any one month intil the last day of such month.

9. Any person who sh: th he guilty of a breach of or who shall fail to comply with these Regulations shall be liable to a penalty for the first offence not exeeding (One pound, and for any subsequent offence not exceetling Ten pounds.

SCHEDTLE A.

Book No.

No.

Department of Agriculture.

Vegetation Diseases Act.

Transport Peruit.

Victoria.

To

I hereby authorize the transport of

of consigned to

bags of potatoes grown by

the

fees have been received.

Potato Inspection District, on which $£ \quad$ : : inspection

are due.

Inspector. 
Book No.

\section{SCHEDULE B.}

Vegetation Diseases Aet.

Depurtment of Agriculture.

\section{Rinoval Permit.}

Vietoria.

To

I hereby authorize the removal from of potrtoes cousigned by at of b.ugs

to on which $f:$ : insuection fees have been received. are due.

Inspeetor.

Markis

$/ 19$

And the Honorable George Gralum, His Majesty's Minister of Agrieulture for the Strte of Victorin, shall give the necessury directions herein accordingly.

F. W. HABBO'T'T,

( lerk of the Executive Couneil, 


\title{
IPPENIIX 1.
}

\author{
EEL WOR.IS.
}

\section{Laidlaw, B.Sc., Microw Biologist.}

The Amguilutide, to which eel-worms belong, are one of the families of the Nematoda, a sub-order of the Yemethelminthes, The Femutoda are a most important group of worms, for not only do we find in it those worms which attack plants, but we also find many attacking man. the domestioted and wild animals, birds, reptiles, and insects. There is scarcely any living thing which may not be attaked by them, and immense lossen from death and dinease are caused by their ravages. Wost of the parasitic ones spend a part of their existence as fiec living animes; many spend their whole life in decaying vegetable matter or camp earth; while a few spend the whole of their existence in the bodies of their hosts.

\section{Axiтosi.}

There are a grat many species in the onder, the determination of which is a matter of very great diffienlty. for there is very little diffecence in their structure however much they may vary in their food and habits. None of the worms are segmentect, i.e. " their bodies are not divitied into a number of segments which serially repent each other, and which resemble, more or less closely, the precerding and sncreeding parts." They possess a few bristles or hooklets, but have no limbs or other appendages, The body is elongated, romnd, and tamering at the end. The head cond is truncuted, and less pointed than the tail, which is usuatly excedingly slender.

All the Vematoda are diocions, i.e., the me and female reproductive organs are in different individuats. The voms, which are usually termed larva, do not difter much from the adults. except in size, and the absence of sexual organs. They are usually free living.

$$
\text { ChRCLLTORY MYATEM. }
$$

There is no closed vasevilar system, but is is probable that the clear colourless fluid contained in the eavity batween the intestine and the body wall, and by which the rarious organs are bathed, is the blood.

\section{RESPLRATORY SYSTEM}

There are no lungs, and, although we know a certain amount of respiration is necestary for the life processes of the worms, we do not know how it is curried on. It may be that the lateral pores have a respiratory function.

\section{('il. I.}

The presence or absence of cilia is a disputed point. I have not been able to make out these small processes of the cells. If none ace present, it is rather romarkable for they are universally present, from man down to the most fowly micellular oramism. "In many animals they are the sole oryans of locomotion, and in almost all they perform most important functions, both in bringing food to the body and in remoring waste matters from it."

$$
\text { ShIN. }
$$

The skin is smooth, thick, and trunsmant. It lines the varions apertures and tubes of the body for a greater or less distance, and consists of three layers-(1) the cuticle, (2) the subcuticle. and (3) the muscular layer. The cuticle is a secretion of the sub. cuticle, and lies ontside it, Cinder the subcuticle and suromded by it is the muscular layer.

The nature of the subeuticle is one of the debatable points in the histology of the Nematoda. Althongh mulei are seattered through it, no cell outlines can be made ont. It is a syneytium or protoplasmic mass in which the ecll outlines cannot be distinguished. A close network is formed from the breaking clown of the cells into fibrils which are specialized round the nerve cords. This tissue is heaped up around the clorsal, ventral, and lateral lines, and divides the endosed muscle cells into four guadrants. In the dorsal and ventral thickenings are specialized nerve cords, and, in the lateral thickenings, lie the excretory canals.

\section{Nervous SISTEM.}

Aceording to Jammes, the nerve tissue is of the same nature as the subcuticnlar tissne, only more clifferentiated, or, rather, it has retained more of the cellular character of embryonic tissue.

The central organ of the nervous system is the circumosophageal ring which surrounds the pharynx close to the anterior end of the body. There are a few ganglion cells in the ring argregated round the points of origin of the nerves. Nerves rum forward towards the mouth. and, ruming backwards, there are six main trunks, the dorsal and ventral being the largest. As before stated, these run in the median, dorsal, and ventral 
thickenings of the subenticular tissue, and are connested, one with another, by fine lateral branclaes rombing through the subcuticle. So far as I know, there is nothing peculiar in the histology of the nervous system.

\section{MISTCIAR KIYSTEM.}

If we make a transwerse section of a nematode, we will see numerons muscle aclls lining the subcutide, except where thr dorsl. ventral. and hatemal thickenings are. The musele cells are spindle slaped and of considemble size. There is a contractile portion next to the subceticle, consisting of a 11 unber of columns in two regular rows. The mechllary half which projects into the body ruvity consist of a fibrillar spongloplasm filled with a clear hvalophasu withont structue, The medullary portion contains the nurlems.

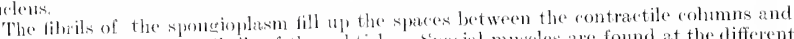
are eontimuse with the fibrils of the subtide. Sireciul muscles are found at the elifferent orilices of the borly.

\section{Boll ('INTY'.}

As mentioned previously, the skin contsius. in its thickness. the museular, nervous and excretory syotems. whet within it lies thr body arity, in which we find the digestive and repoduction systems, There are no mesenteries dividing the body cavity into compartments. It contains ab colourless coamblale thid with many corpuscles, which

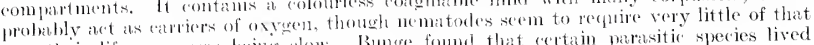

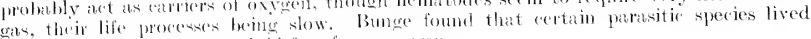
from fom to sic days in a flokl fide from oxygen.

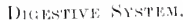

The month is anteriog and terminal, anc besk into an alimentary cand which runs stmight throush the hocly to the anus. Which is situated on the ventral side of the body and is not terminal. This simple tube nuy be diviled inte three main parts the aropolnegus, the intestine, and the rectum. The asophegus extemels from the mouth to the intestine. It is triangular in section. linet with antiche continuous with the skin covering the bosly, and, like it, is shed at the verious moulds. [ts walls are thick and musculas, and it las as its posterior ond a hubous swelling alapted for a special purpose. It is arned with a spear in the species moler consicteration. The spenr is used to pierce the fissues of the phant upon which the animal lives. I smatl gland. supposed to be

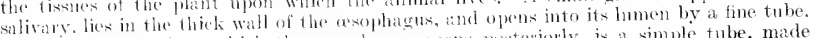

The intestine, into which the asophaters opens posteriorly, is a simple tube, made up of a single laber of nucleated colmmmat eells. The internal wall has a coat of a dhitinous mature which has many minute pores. The roctom is short. and its entioutar lining like that of the asophagus, is cast at intervals. The rectum posiesses a sphincter.

\section{ExcReTory hyster.}

The excretor system consiste of two canals embeded in the lateral thickenings of the subenticular tisise. They end blindly behind, but anteriorly they bend downwards and open by a common pore on the ventral suface near the lead. They eontain a fluid, but nothine is known of its composition. ('obb supposes it to be wrinaly in its nature.

\section{Reprometetye Orgast.}

The sexes are distinet, the males leing smaller than the females. The genital opening in the fomale is ventrat and near the middle of tle body: while, in the mate, the anus serves for the genitul opening as well as for getting lid of the excrement. The male has a genital bursal and one or more spicules at or near the cloaca.

The introul organs in the mate comsist usually of a single tube, which we may divide into a testis, a vasteferens, a vesicula seminalis, and an rjoculatory duct.

In the testis the protoplasmic grautes enlarge and become elongated cells (mother e(Hs), which group themelyes abont longitudinal axes or rachises. There may be as mally as ten of these axes. As these mother. cells mature they become detached from rach other, and so give lise to the spermatozoa. The spermatozoon of a nematode has no flagellum: and, though it amot nove actively, it has a well-defined amoeboid movement. The spermatozo do not become mature till they reach the uterus of the female

The intrmal reproduetive orems of the female are double, and eonsist of ovaries, oviducts, and uteri. The vagina is single, and is lined by a continuation of the enticle covering the body. The ova arise from the germinal epithelium at the blind ends of the ovaries, and. as they get pushed forwards into the tubular part, they entarge and arrange themselves aromind a central axis or raehis, which seems to be formed by the eodtesting of the ends of the cetls. In the small free living forms there is no rachis. The ovum has a cell-wall enclosing a reticulated protoplasm with nueleus and one or more nucleol. After copuliation, the spermatozoa colleet in the ovary close to the uterus, and here the ovmm is fertilized. After fertitization, the egg aequires a shell which is 
probably deposited around it from the semi-fluid contents of the uterus. The shell is ehitinous and very resistant to chenicals. Drying or soaking in water has no effect on it In sone speeies it is provided with a process which enables the embryo to escape one eack coming of like a little lid or cau.

The eggs ciffer greatly in their rate of development, karyokinesis gotrse on much moje rapidly in some than in others. This is probably, in a great measure, due to the artificial conditions under which the observations are made, Eggs that have been driod for montlis and then moixtencel, hatch out. stse embryos showing movement within the egr in less than two days. Wach female worm produces from 2.50 to 300 egges. As the life cycle is romplete in three weeks or so, and, as there are ten or more generation in the year. it is not difficult to understand the spread of the pest.

The foregoing description of the Femede anplies also to the gencrib whicl attack plants, viz. Tylenchas, A phelenchus, and Heterodert.

Heterodera radicicola, the potato cel-worm, is

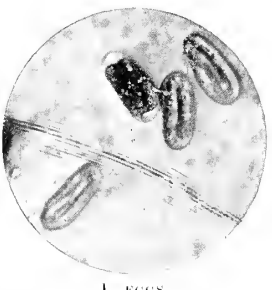

1. eac:s about one-twenty-fifth of an moh in length, being just wible to the naked rye. It eanses swellings or blisters on the tubers, which often break down, causing seablike blemishes on the skin.

$$
\text { ('ISTS. }
$$

If we take a potisto showing these swellings or blisters, and cut it at right angles to the surface, we will find. under the skin, at defthe varying from is to of an inch. Litte rommed eysts which are quite visible to the naked eye, being about the size of a jinheat. These are the femate worms which have locome distended with egus, In ab

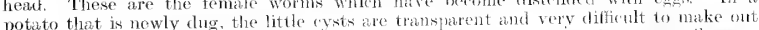
with the naked eye; but, in one that has bern kept for some tine. they are easily seen as the cyst becomes opaque and pearly-white in appearance, and by-and-by some of

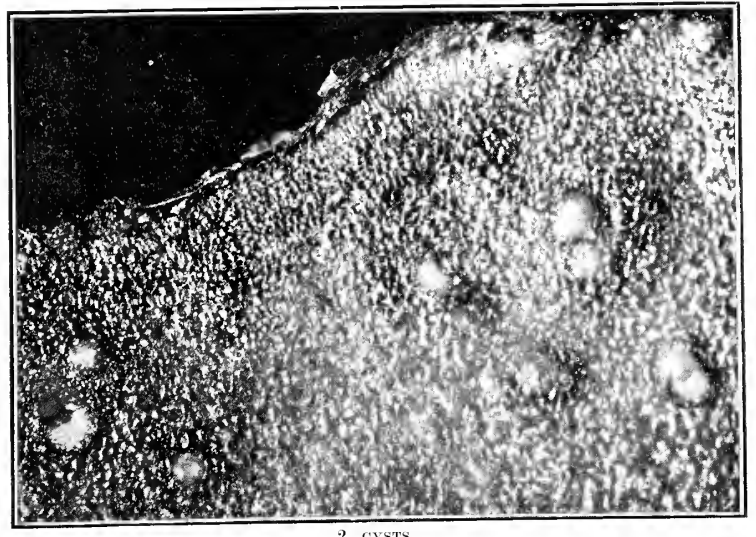

2. CYSTS.

the starch cells in the meighbourhood become brownish through degencration. In a potato that has been ding for some time the cysts are easily removed for the pumose of observation, the wall of the eyst, which is really the epriclermis of the worm. having become tougher with age. If we place an individual cyst in water it swells up by osmosis, and usually a protion of the contents is expressed. From the contained eggs, living worms are hatehed out in eight days. This, no doubt, is slower than it will be in natural eonditions, owing to the difficulty of keeping the eggs with just the requisite amount_of moisture. 
LIFE. HT TORY.

Thie nsual life cyele of the potato worm is quite simple. When a potato with blister, i.e. with the female in the cystic form, is planted, the embryo worms are set free in the decaying set, through the rupturing of the body of the adult. These find their way into the soil, where they live till they are sexully mature. (onjunction of the sexes takes place, and the females bore their way into the young potatoes of the new erop there to eneyst themselves again.

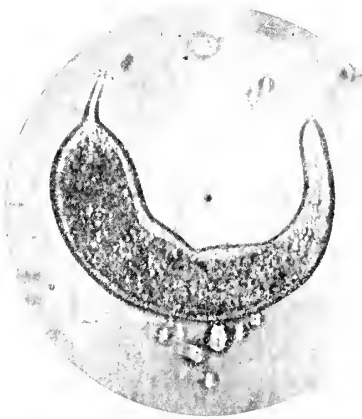

3. FMUL WOKH

The aceompanying micro-photograph show's the female at the commeneement of the erstic stutere.

It must be borne in mind that this worm can pass through its whole life eycle withont becoming encysted in a tuber, as it is able to live in the decaying vegetable matter in the wil. In this case the female foes not become distended with eggs, fewcr being produced.

To obtain a pure culture of the potato worms, an infected potato was washed and placed in sterilized soil. After a time the worms wore collected from the sill and decaving set. ale having been taken during the prediod of growth to water with nematode-free water. By feeting the worms on mmall pieces of boilal putato and onion. I was able to keep them alive and healthy. They went through their whole life cycle in the fres state, an slowly inereased in numbers. The females did not beeome "citron shaped," and were guite an ative as the mates. So non-motile larva were obscrved.

The danage to a copp is mainly caused by the females, sexually mature males being scldom found in the 1 iscues of a potato.

When a eulture of potsto worms is kejet for some tine, littlo white duts, the size of a small pun's head, will be found on the sides of the dish. guite away from the food and moisture, On removing one of these small rumper to a microsepie sicle and moistening it with water, it will he fommel to consist of a mass of worme of all sizes, except the smallest larve. though there are, as a rule, very fow kexully mature adulte.

I allowed owe of these clishes to dry up complete? months. At the encl of that time I took one of the lifte d.ied-np elmperand placed it on a slide with some water, and, in a few hours, the worms were moving about in a lively namner. This gathering into clumps may be adofted by the worms as a means of preservation, for it is generally seen when the food supplies or the moisture in the dislies are beeoming low. Or this massing together may be a means of enathling a colony of young and vigorous worms to be transported more readily from place to place by the ageney of animals, birds, insects, \&e.

\section{Chaxges in the FoO1) FípPl.}

All the groups are, to a certain extent, restrieted in their choice of food. When their natural nutriment is withheld and something else substituted, they become sluggish, reproduetion eedses, and many of the worms die before they are able to adapt themselves to the ehange. These fact point strongly to the advantages to be gained by rotation of crops.

\section{SAPROPHYTIC WORMS.}

Minute nematodes abound in moist soil, around the roots of plants, and in deeaying vegetable mitter. They are not elirectly parasitic in plants, and, so far as is known, do no harm. As many as six different genera have been found in the blemishes on the skin of a damaged potato, and, in some cases, not a single one of them belonged to the family Heterodera.

I have never sueceeded in keeping worms alive for longer than three or four days that did not belong to the families Tylenchus. Aphelenchas, or Heterodera; and this, with the anatomie differences, to my mind, proves that many of the worms regarded as injurious are merely saprophytic.

In soil sterilized by stean for two hours I planted very seabby potatoes containing nenatodes in the blemishes on the skin, but no cysts. Previous to planting, the tubers with the exception of the control, were steeped in 1-300 formalin. When dug, the tubers 
showed no trace of "scab." All of those from the unsteeped "set" showed more or less seab. The same procedure was earried out with potatoes having cel-worm eysts; and, in every case, steeped and unsteeped, eel-worm was found in the young erop.

Seientists do not agree in their statements with regard to eel-worm, one remarking that "Though eel-worms are almost miniversally eonsidered as doing great injury to eultivated plints, and in all probability such is the ease, yet $I$ have often wondered whether they are always the primary canse of misehief. Experience has tanght me to always look for fungus mucelium when I cut an eel-worm gall, and I am rarely disappointed"; while another says that "The fungus is always secondary, the primary damage being eansed by the eel-worm."

For my own pait, I consilee both are right and both wrong; for I have examined many plants where the primary, and, indeed, the only affection was due to the eel worm, and I have examined quite as many where the eel worms found were mere saprophytes living in the deeaying tissues of the plant, the primary damage having been cansed by some other agency.

\section{TREATMENT.}

Varions remedies have been trief, such as saturating the soil with carbolie 1 in 20 ; gas lime spread on the soil and intimately mixed with it; mixing naphthaline with the soil ; and sulphate of potash, 4 cwt. to the acre. I have had good results with both carbolic acid and naphthaline, but they are too expensive to use over large areas.

Experiments are at present being carried on by this Depurtment for the eralication of the pest; and, thongh they appear very successful, it is too early in the season to speak positively.

In using any insecticide, it must be applied three times, a fortnight intervening between eaeh applieation; the reason for this is that the eggs hatch ont in from eight to ten days in favorable circumstances. The first application lills off the adult worms, and the sueeeeding ones kill the worms hatehed out from the egss already in the soil.

A dressing of peaty soil was tried on onion eel-worm infested soil at Portarlington, with no result.

Steeping seed potatoes in formalin or corrosive sublimate is of no avail. The ehemicals do not penetrate deeply mough to reach the cyste, and, did it reach them, it would not kill the egas, the envelopes being very resistant to all kinds of chemiculs.

Growing the same crop year after year on the same ground is the greatest aruse of the soil beoming infested with eel-worm. They can live on a great many plants cultivated and uncultivated. but they can only change from one kind of plant food to another with diffieulty. Hence, when rotation of crops is piactised, the worms never become a serious menace to the famer.

In selecting seed for plinting, the grower must see that it in free from "blisters" or galls, rejecting all that are in the least simpicions, for, mless a potato is badly affected. the infeetion is not easily seen.

\section{H.f.USTR.itions.}

1. EGGS OF POTATO EEL-IVORM $\times 120$.

2. SECTION OF POTATO SHOWLY CYST $\times 10$.

3. FEMALE WORM IT THE COMHEXCEMENT OF THE CYSTIC STIGE $\times 160$. 


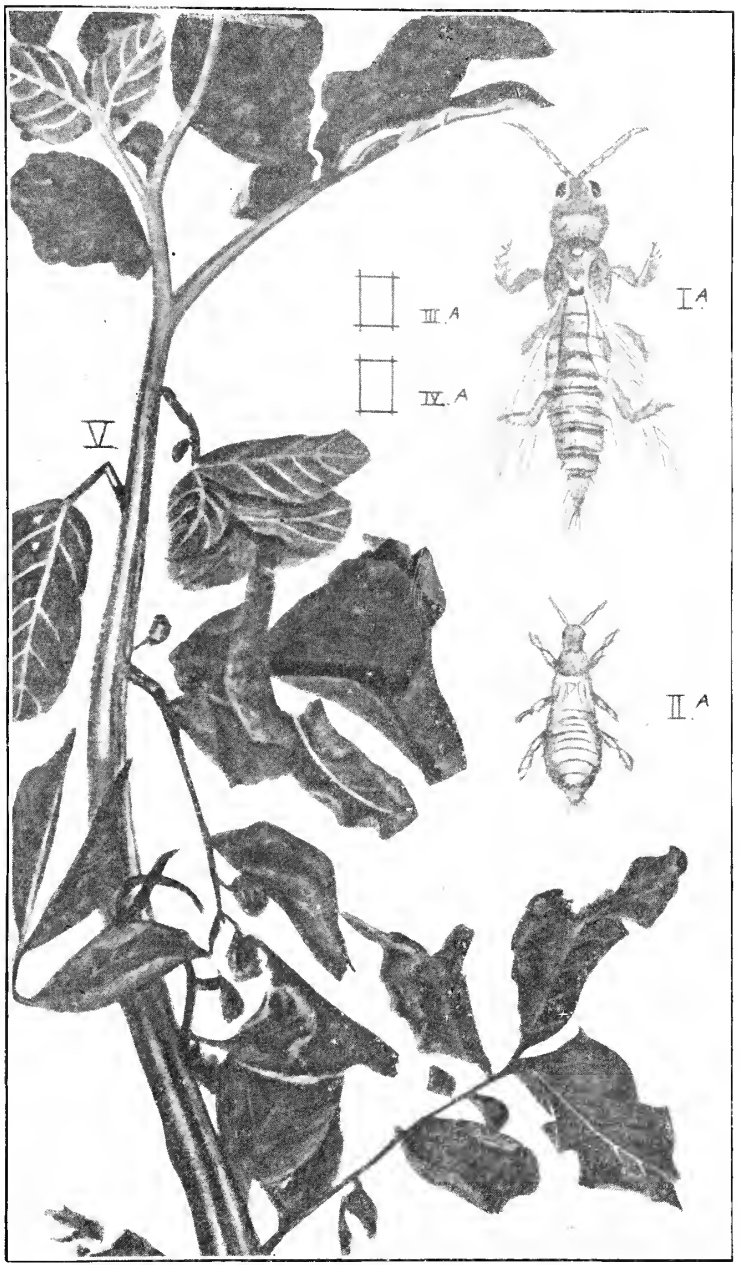

1. Potato thris. (Thrips tabaci, Lindemann.)

$$
\text { EXPLAXATION OF PLATE. }
$$

Fig.

IA. Female, Perfect invect. Piagnified.

IIA. Periect insect. Hagnified.

III. Perfect insect. Natural size.

IVA. Jarva. Natural size.

$\checkmark$. Potato stem, with foliage dying. Tatural size. 
INSEG PERT OF THE POTATO.

C. French, Ir., Alting Government Entomoloyist.

\section{INTROHUCTION,}

Many of the insect peste of the potato known to science are found in Victoria, though, fortunitely. we have not the dreated folorado beetle and some others whieh are prevalent in Amerien and elsewhere, With the eareful inspection and quarantine in Hellourne of all potutoes arriving from abroad, growers have now less fear of new pests being introduced. Should any such apreikr it would be advisable to at onee send specimens to the Department of Aericulture, in order that action may be taken for their silp)

Many native insects whose naturul food is being destroyed as new land is brought under cultivation are turning their attention to the potate and other erops, so growers shoukl al ways be on the alert. With the modern outfits, the spraying of erops is now an easy matter, and most of the che micals userl are olytainable at a reasonable price.

Nost of the insects descrileed in the following page's are known to growers, and on this account their technical desctiptions have been curtailed.

\section{THE POTATO THRIP.}

(Thrijs tubsei, Lindemann.)

During the last few years these destructive little insects (jrobably introdneed from Europe) have cansed grower's considerable losses, and they are unfortunately on the inerease. They attack plants of all kindis.

If detris in sheltered places is examined during the winter months, the thrips will oceasionally be found in great numbers. They are very slow in their movements, and a severe winter is the means of lessening their numbers considerably as they eannot stand ('old wet weather'.

Where they have survived the winter the first warm day in Oetoler brings them out. I'liey then appene in millions as if by magic. If the potato leaves are examined underneath, the thrips will be found in all stages of development. The lower leuves of the plant are generally attacked first, and, as these are destroyed, the top ones are affected in turn. In a short time the whole plant shrivels mp, and the potatoes are often only the size of marbles.

In Victoria the life cycle of these insects is as follows:-Development of egg, 3 to 4 days; development of liava, 7 to 10 days: development of nymph, 4 days; total development, 10 to 15 days. In other countries they have taken as long as 47 days to develop. Should the weather be warm, the eggs will of course develop more quiekly thin in cold weather. They are deposited in slits or other well concealed positions on the stems and foliage.

\section{Prevention axp Rementes,}

The thrip pest is indeed a serions one, and growers will sooner or later be eompelled to take united action against it. otherwise it will be almost impossible to grow good (rops.

All dibris, such an dried potato plants, weeds. \&e., on potato fields should be gathered 11) and burnt. By this means the hibernating insects and their eggs will be destroyed.

During lolo. Hr. Q. Seymour, Potato Expert, and the writer carried out some experiments at Romsey against thrips. A Strawsonizer spraying outfit was used. This was fixed in ab dray and worked very satisfactorily, the spray being forced up under the leaves so that the plants reecived a good soaking. Tobaceo water was used with good results, This wash requires careful straining, otherwise it is liable to ehoke the nozzles of the pumpr. and that would leave many plants unsprayed. The formula for tobaeco wasll is as follows:- Steep $1 \mathrm{Ib}$, of tobacro in 1 gallon of hot water, and allow it to soak for 24 hour's; boil $1 \mathrm{lb}$. of soap in 1 gallon of water until the soap is dissolved; strain the tobace'o water into the soap water; stir well, and make up to 5 or 6 gallons. Use waste stems of tebikce.

Benzole emulsion, a cheap preparation, costing about $4 d$, per lb. wholesale, has proved very effective, One $1 b$, make: is or 6 gallons of spray. and every insect reached by this mixtare is killed at once. Now that many motor spray pumps are on the market, the work of sprayinge ean be done thoroughly and in a short space of time.

Hedlebore or a weak kerosene emul,ion, has also given good results as a spray fluid. In Anerica the use of lime in the following proportions has been highly reeommended :$35 \mathrm{lbs}$, of lime to 100 gallons of water. In other cases, a stronger spray using from 50 to 7.5 Hbs. of lime to 100 gallons of water was used with the best results. 
The potato thrips and its control have been the subject of experiments conducted in America by $\mathrm{Mr}^{2}$. Dudley Moulton. The results are detailed in Bulletin 80 , published by the Cnited States Department of Agriculture. Thrips which attack other kinds of plants and trees may be combated by the same remedy which he gives for the potato thrips. From an extensive reries of trials of varions kinds of spray fluid, Mr. Houlton eomes to the eonchusion that, though tobacco leaf extract, one part to 50 of water, is very successful, yet a more penetrating and hence more effective material is got by making up the tobacco leaf extract with an oil instead of witl water only. The oil spray is forced more easily than the water spray into the buds, and penetrates more readily the oily covering of the insects themselves. The oil spray recommended is composed of:-Distillate oil emulsion, 1 , to 2 per cont. solution; black leaf-tobacco extract. 1 part to 60 parts of water. The distillate oil emulision is prepared as follows:-Hot water, 12 gallons ; whitc oil of fish oil soat). 30 lbx.; distillate oil (2:3 degrees, Bame), 20 gallons. The soap is dissolved in a kettleful of boiling water, and poured into the spray tank; the oil is then added, and the mixtme in agitated violently, and spraved under a pressire of 125 to $1501 \mathrm{~lm}$. into other barrels. This stock solution is diluted before use with 24 gallons of water to rach gallon of solution.

As a deterrent against thrips, spraying with coal-tar water has been recommended. The formula is as follows:-Boil $1 \mathrm{lh}$. of coal tar in 2 gallons of water, and, while hot, add from 50 to 100 gallons of water.

Several of the accompanying illustrations have been reproduced from The Destructive Insects of Fictorid by (". Fench. F.L.S., F.E.S.

\section{('UT ITORYS AND LOOPER C'ATERTtLliks.}

These include a number of diflerent but closely allied species variously known as Cout Worm C'aterpillars. Looper ('aterpillars, Army Worms, Take-all (trubs, de.

Plate fo, 2 shows some of the rommon cut worm moths, also two other species of (losely allied Noctuids (night moths). In the Wuseum of Economic Entomology and Omithology of this I beperment are specimens of all the Victorian Cut-worm moths, their egers. and latide. The collection may be inspected by all interested.

Of those shown in the plates, the Silvery Mothe (Plusia rogentifera) is at times des. tructive to potato crops in many parts of victoria. Complaints from growers have also

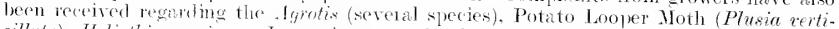

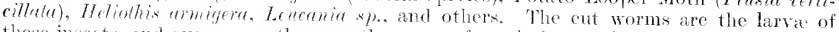
these inserts, and every year they are the cause of much destruetion on farms. vineyerds, and gardens. Whest, oats, barley, maize, vincs, plums, tomatoes, onions, beans, cablages, and potatoes are all subject to attack.

\section{LTFF HTYTORX.}

Closery allied as they are in their habits of life. differences between individual members of this group are chichly morpholosical. There are at least two broods of cut worms in a seasen, but further observations will be necessary before the number is finally asecrtained. The moths usmilly fly a lout at dusk. and deposit their eggs on anv suitable plant. The eges hatch in a few days, and the ronng cut worms begin to feed at once, any kind of green food being geedily eaten by them.

The cut woms vary in colour according to the species, Those of the Tomato Noth vary from green to vellowish, but most of the Agrolis are f a dirty grevish or light-brown colour, without hairs or spines, smonth. and greesy looking. often being of a similar colour to the ground in which they hibernete. Some of the cut worms feed both day and night; others rest Juring the day just under the soil, or under logs, stones, bark, bags. and rubbish, and feed only during night.

They are fully grown in a couple of weks, and are then ready to pupate. The pupa is of a dirty reddish-brown colowr, sometimes almost black. After pupting, they remain in the ground from ten to fifteen days during warm weather before the moths emerge; in cold woather the period is much longer.

\section{REMEDES.}

By the eradication of weeds and the burning of haulms and stems of $l$ arvested crops the cut worm cril may be greatly minimized, as by this means many cges are cestrcyed.

Growing crops may be treated in the following manner:-Place between rows of an infested 'rop' or at short distances apart, bunciles of any succulert wecd or vegetable which has been previously poisoned by dipling it into a strong mixture of Par's green, l oz, to a bucket of water. The rut worms eat the poisc ned plents. br ry themselves and die. In hot dry weather the ludils should be put out after sundown, Correspondents have frequently inquired whether there is ary likelihood of vegetables absoibing Paris green from bundles when plaeed l eax the roots. 1 am assured by the Chemist for Agricultule that there is no danger, as Paris green is practically insoluble, and therefore camnot be absorbed by plants. 


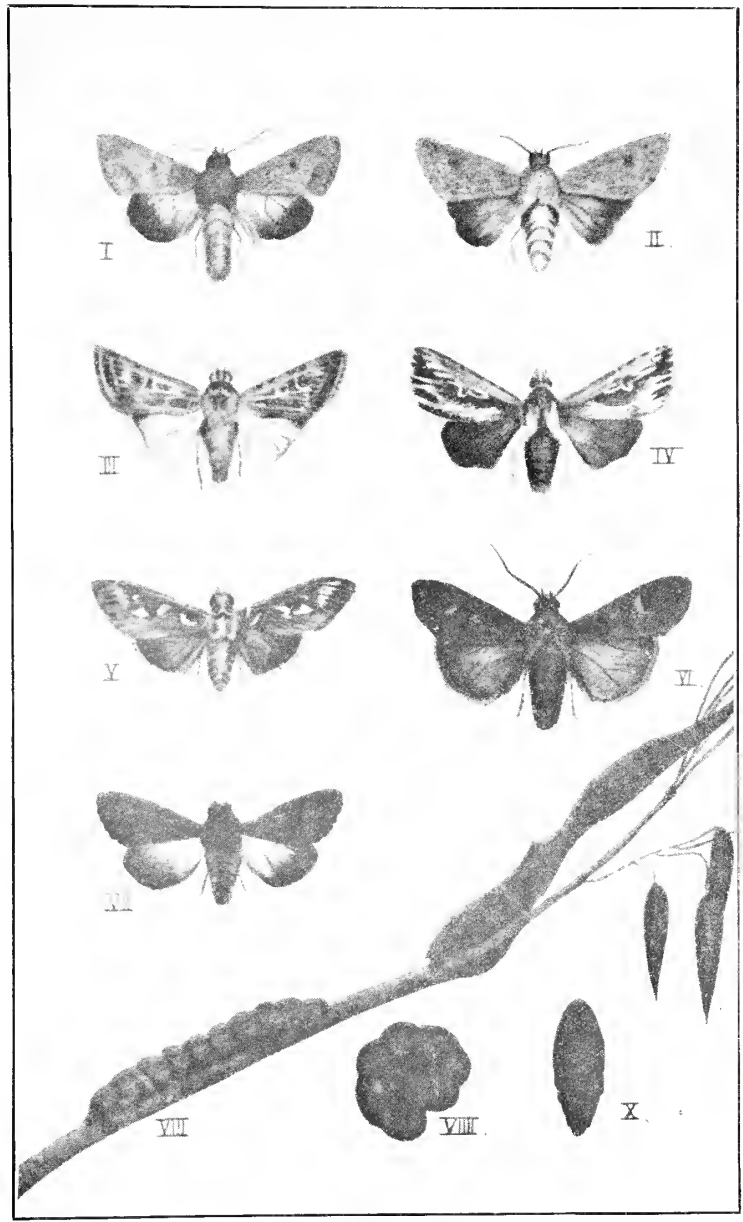

2. "UT WORM MOTH'.

EXPLAXATION OE PLATE.

Fig. I. Chiorideen stroletes. (Tomato Mioth.)

1I. Cirmitis unipunets

III. Euxos reterings.

IV. Persectsmin etengi. (climbing Cut Worm.)

V. Plusia argentiferi. (Silvery Jioth.)
Fig.

YI. Ayrotis spine. (Bugong Afoth.)

VII. Euplexis nigporima.

Vlll. Larta of Ayjotis.

IX. Larva enrled up.

X. Pupa of Agrotis. 


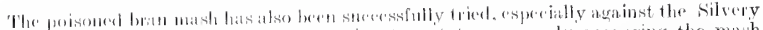

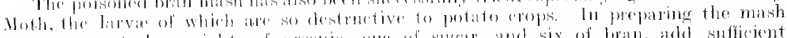

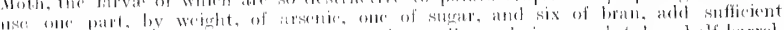

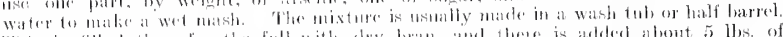

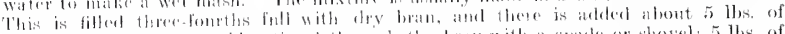

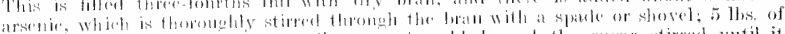

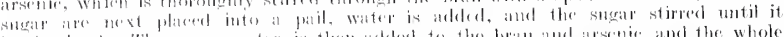

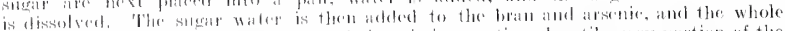

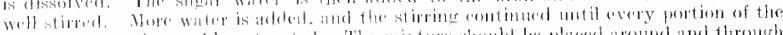

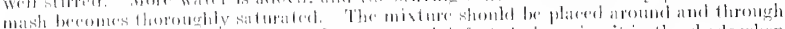

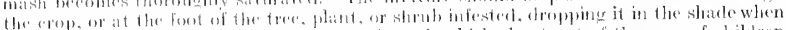

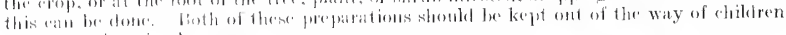

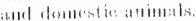
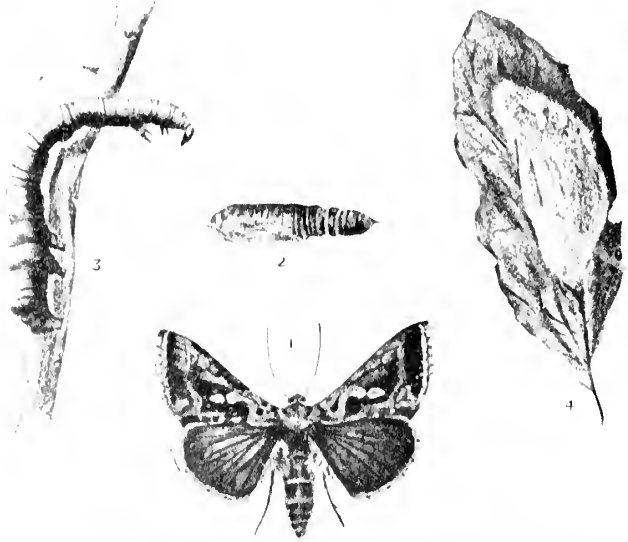

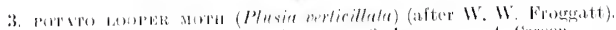
1. N1411. . I 31 h.
2.. Pap1.
3. Liva
4. (언)(11.

With remal of the eficang of the poisoned has mash. I have recently received the

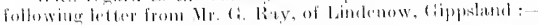

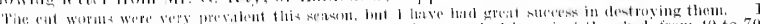
had

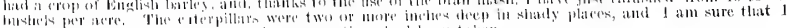

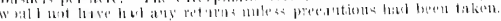

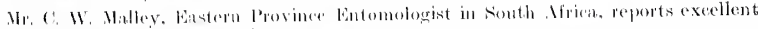

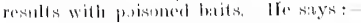

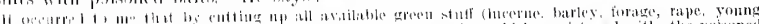

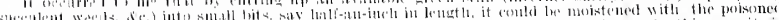
simethem

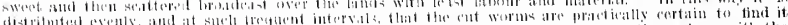

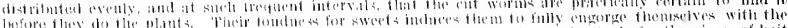

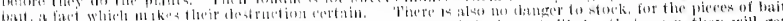

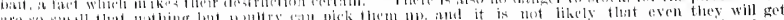

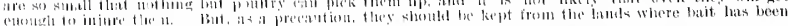
sirate.t.

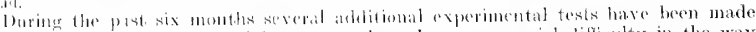

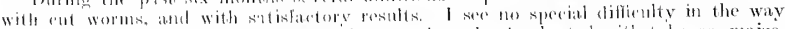

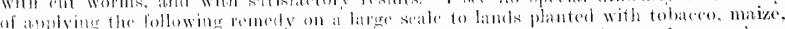
of olher crops. and therefore ail aftention to it for the benefit of any who mab have oceisiofof to nse it:

Method of Prepentation.

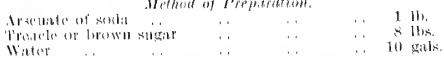

Dissolve the arsenate of solat and the treache in the water. In the meantime ent up

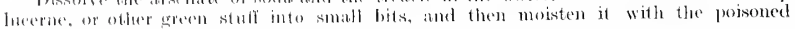




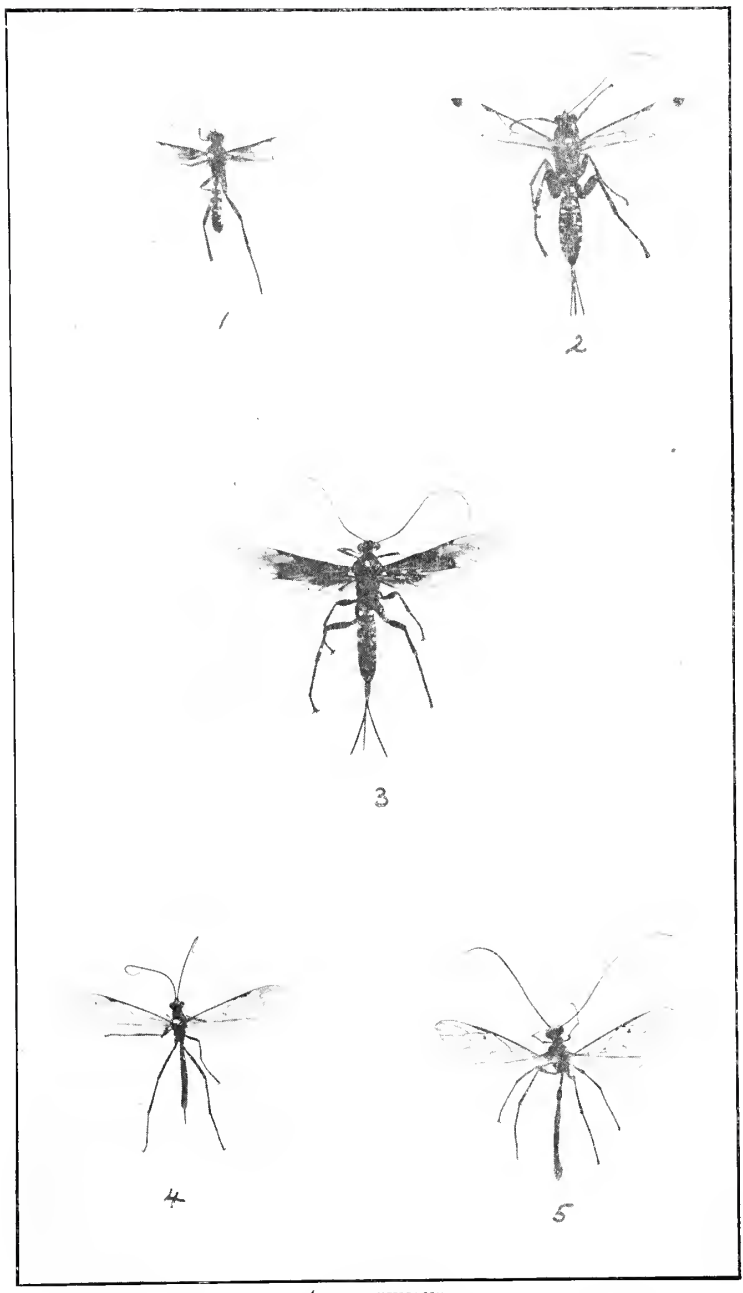

4. ICHNEUMONS.

(D.urk winged lehneumon.) Beneficial lnects. Destroyers of l'otato Insect Pests. EXPLAXATION OF PLATE.

Fig.

F. and II. Rhyssc semimunctenta, Male and Female.

III. Pimpla intricatorit. (Spotted black Ichmemmon.)
Fig.

IV. Ophion sp.

V. Ophion sp. 
sweet. Be carcful not to make it too wet, or it will not scatter well when broadeasting. For the hest results, the bait should be distributerl a few days after the gromal has been plonghed, and all green sucenlent vegetation destroved. The ent worms that are not injured in ploughing will then be on the surface again, and on account of their long fast, practically all of them will be prowling about in search of fool. In this way, one applieation will probably be sufficient. If injury is noticed after the young maize plants appear, the application shonld be repeated.

Where a spray is employed in place of poisoned bait, arsenate of lead has proved one of the best. By using this spray growers in the Frankston and (heltenham districts have saved theip potato crops from the ravages of the Silvery Noth. Where cut worms are feeding in grass padalocks adjoining crops, it is advisable to spray a strip of the crop. liter devouring the grass they move on to the crop, and, when they come to the spraved portion, devom it greedily. and are soon destroyed. If vegetables are sprayed it is advisable to thoroughly wash them lefore using.

The tranch system is ample and effective method of erartication. A trench or furiow shonk he either plonghed or due around the crop towards which the ent worms are feeding. It must have clear cut silles; those nearest the crop should be undercut so as to prevent the "ut worms from crawling ont of the trench. Deep holes should be made in the trench at intervals of. sav, is yards. When travelling towards the crop the cut worms fatl into and craw along the trench and ultimately into the holes. A few shovelfuls of eartl, wetl rammed, will then speedily destroy them. Should the pest be already in the crop, it may he useful to run o few furrows through it to prevent it spreading.

Another plan that answers well is to place al flock of sheep in the infested paddock adjoining the geass crop. The constant walking about of the sheell will (kestroy many ent woms.

If cut worms are prevalent in galens, rake the geound up close to the plants. By this means meny of them are turned $11 \mathrm{p}$. and if poultiry are allowed to rum ower the ground, very few will essape their notice. The are also rosily injured by the rake, and are then likely to be anten by ants and insectivorous bials when exposed on the surface of the giound.

Numbers of cut worms are destrovel by hymenopterous an other parasites. Very

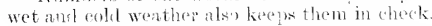

\section{POTATO MOTH.}

\section{(Lita solunellu, Boist.)}

Acoming to verions writers this destructive yest of the potato crop has been known

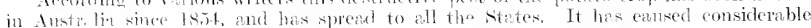
losses to soumers. and is certainly the workt potsto pest in the commonweath.

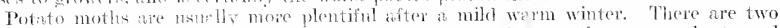
broods of moths. The first. the winter mood, may destroy the young plants and therebr pun the arep. The moths of the second brood deposit their egen on the potatoes themsches when the tubers are stored or are in the field. Occasionally, especially if potatoes are grown in stiff soil, the moths will crawl down the clacks in the gromel and

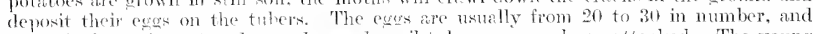
hat h in from sis to ten days. In sondy soil tubers are ravely so attacked. The young

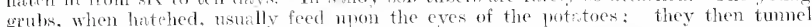
towards the center of the tubers. camsing them to become brownish blek, and inducing decar. Sometimes when the potato plints are fully grown the female moth deposits here eges on the leaves. The young grubs feed on these. and afterwards gnew their way down the main stalk, reaching the tubers below. Fortumaty for gavers the chrysalid. of the potato moth are attacked by parates. barterial diseases. and chmatic influences, which destroy great numbers.

\section{LTFE HIৎTORY,}

Eggs. - Very minute, of ib white colour and glistening.

Caterpllor. When fully grown it measures about 1 inch long, and is of a faint pinkish eolour, with a brown head. It usmally pupates uncler the skin of the potato, and is smrounded or protected by dirt, excrement, \&e.

Chryselid. The pupas or chrysalil is dark brown in colom, and is enclosed in a silken bag or cocoon.

1/oth. The moth is small, of a light brownish-grey colour, the size being :-body, about 1 inch in length; front wings, which are darker than the hind ones, female, about 3 inch across when expanded, male slightly sm:ller. The wings of both sexes are feathery or fringy, but this is not so pronounced in the male as in the female.

\section{Prevention and Remedies.}

Dear potato plants. discarded and small potatoes. and rubbish shonld be gathered and birnt. Old sacks and eases in which there have been infected potatoes should be dipped into boiling water. By this means any grubs and chrysalids secreted in them will be destroyed. 


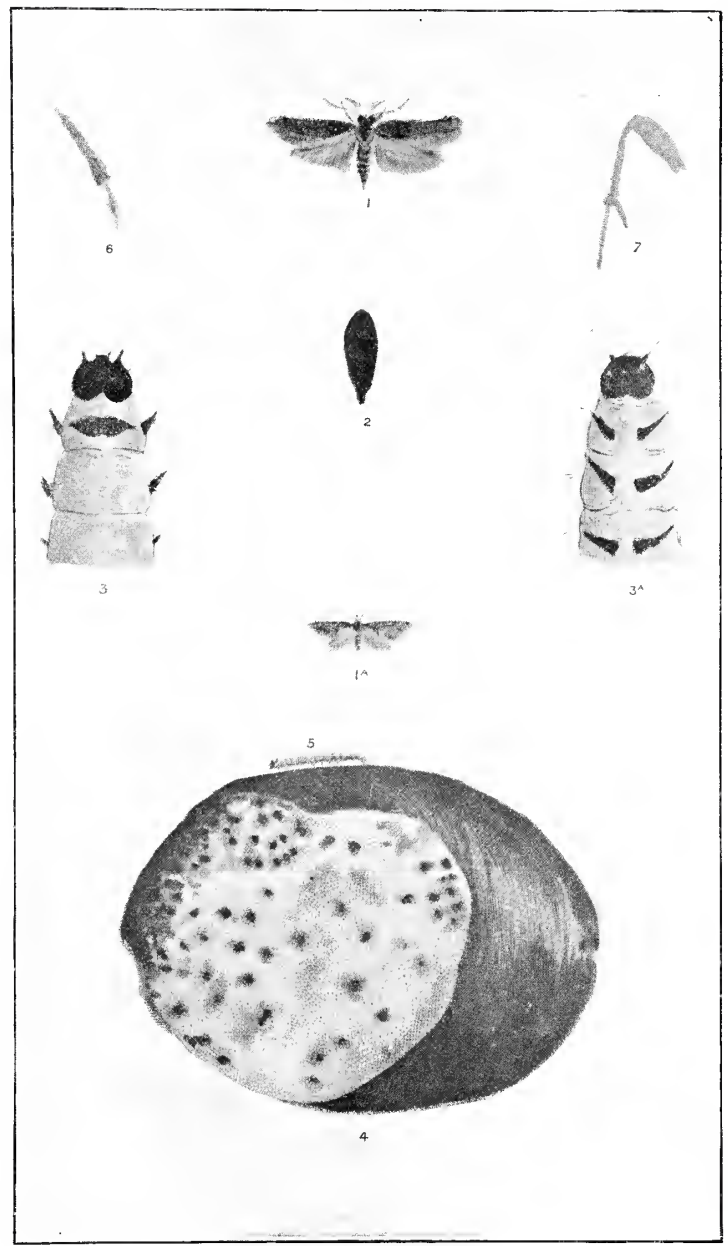

5. Potato мoth (Lita solinella, Boisd,) EXPLANATION OF PLATE.

Fig.

I. Yoth. Magnified.

is Yoth Yatural size

II. Pupa. Magnified.

III. Head and first three segnents of larra. Upper side. Magnified.

IIIA. Head and first three segments of larva. Under side. Mragnified.
Fig.

IV. Potato sliced to show effects of attack by larve of moth. Yatural size.

V. Larra. Natural size.

vi. Foreleg. Moth.

ir. Hing leg. Moth 


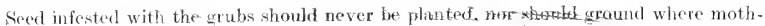
affected potatoes wore grown the previort year be used again for potatoes. Ftant the secel dectly, and keep if well covered. The sround shorbl the pressed firmly down, and it is advistible to till it a soxomel time. Sover leave potatoes exposed in the field. When they are dug al) they shomld be at once bagged and removed to the storeroom, where they must be pluces in bins. pits, or any other plieces where moths cannot get at them to hav their cogen in the aves of the tubers. It is a common practice with many growers to simply heap the potatoes up in the storeoom without any covering, and to

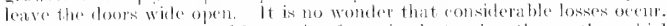

Trappling by mome of lamps is of $11 \mathrm{ar}$ in destroying the moths, which fly about at night. P'rowite an solinary tin batsin, and in this place a brick and conough kerosene to ratele half way up the brick. and on the brite a lighted lamp. The motlis as attrated to the light, and, flying against the lamp, fill into the kerosene, whinh kith them. The basin combl be placed on an ordinary box streth as a kerosene ease.

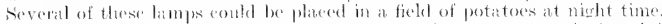

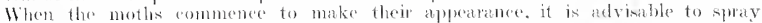

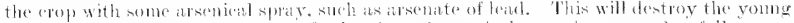

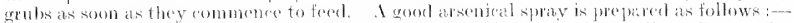

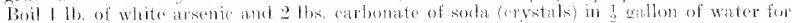

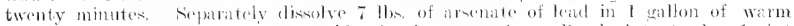
water. When both mixtures are cold mix them tosecther. Botele into twalve 1-pint

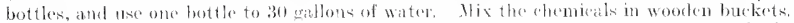

Is many reliatile brands of arsenate of loud are now on the market, and at a fairly

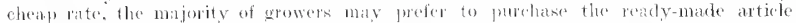
insterel of somer to the trouble of mixing this overllent spray mixture themsedres.

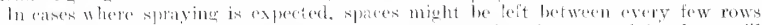

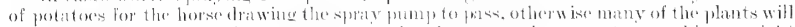

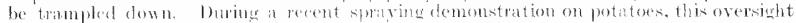

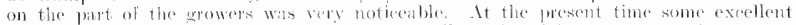
motor, andomatic. and other spray pimps, sperially desiened for potato sprayines, are on

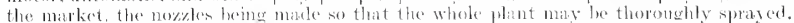

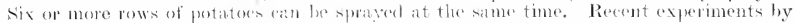

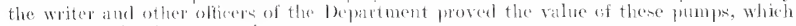
are now rominer into cenerial use.

As the potito moth is proclamed an inseet pest under the Tesetation Dineases Avet, it would be advisible that the potato inseretors should inspect all storeroems in

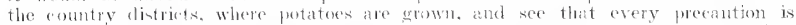
titken by erowers to proted the tubers from the mages of this moth. One careless

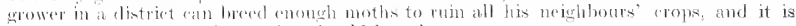
ageninst such it grower that action shond be taken.

\section{POTATO AND TOMATO WEEVIL.}

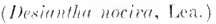

This is a comparatively new pext of the potato, and was first reported in becember, 19os, from the Essencton distriet. Here it caused young potato and tomato plants to tall to the uroumel by eating the stems through at the base. It has now been found in

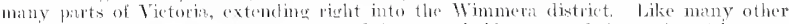

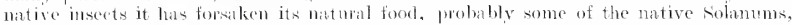
and taken to potiatoes and tomatoes. Varions veugetables and garden plants are also at tacked by it.

The larvat is of a light pea-green colour, and measures about a chater of an inch in length. In the daytime it is uxmally fomed in the soil a few inches below the surface. Whien about to pupite it construets a cocoon mate of soil, where it remains for a eouple of monthe mintil it mereses as the perfect beetle.

The beetle. which measures about a quater of an inch in length, and varies in colour from light exey to dirk brown. Some specimens have a V-shaped mark on the wing cases, and two projections, one on each side of the wing eases. It is quite as

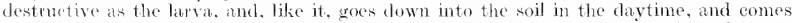
up to fered at night, The larva often feed in the daytime as well as at night, but the perfeet inseets rarely do so. It is a polifie heeder, and every possible means should be adopted to prevent its spread. It may be seen at all times throughout the year, and the dimage clone is consilerable.

\section{Prevextron AND Rembies.}

All weeds, especially marshmollows, on land aljoining potato crops should be destroyed. This insect will eat almost any kind of weed. so it is necessary that these preatitions be taken. Fortunately, in the arsenate of lead spray we have an excellent renedy for this pest. Experiments carried out by this Branch prove that by this means it eun be kept in eheek. 


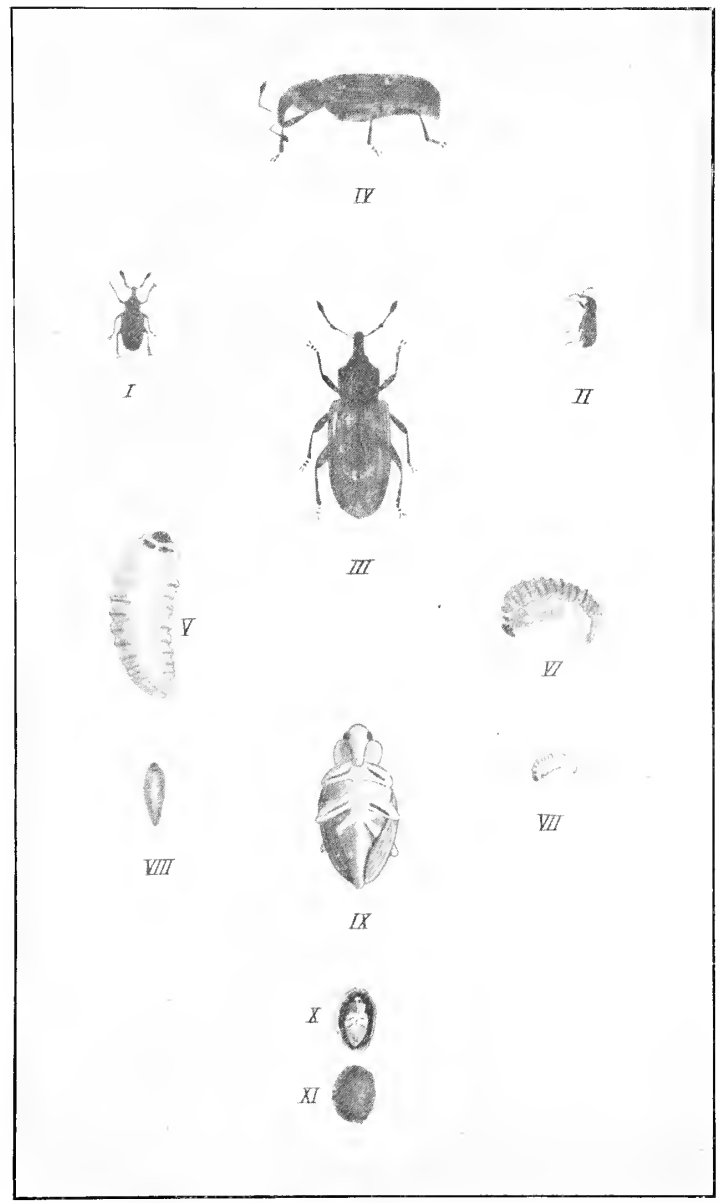

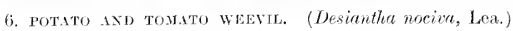

EXPLANATION OF PLATE.

Fig.

I. Perfect insect. Yatural size.

I. Perect insect Satural size Side view III. Perfert insert. Enlarged.

IV. Perfect insect, Enlarged. Side view

V. Larva. Enlarged.

vi. Larva. Enlurged. Side view.
Fig.

VII. Larva. Tatural size. Side view.

VIII. Larva. Yatural size. Side view.

IX. Pupa. Enlarged.

X. Pupa in coecoson. Natural size.

Xi. Cocor. Tatural size. 
JASSIDS, LEAFHOPPERS OR FROGHOPPERS.

These are mall grecnish-yellow insects. not unlike miniature cicadas, and about the size of the athicfes on roses. Thev are rery artive, and can be seen in thousand on the leaves of atl kinds of plantr. now and again doing damage to the young shoots and foliage. latres numbers are oftrin sepen on potato plants

These insects do not seem to ciunse any notiereable damage, but, as they apprear to be on the increase. it wonld he as well for urowers to keep a strict watch for them. If found calsing any damage it would be necessary to spray the crop with Benzole emutsion. I t) 5 gullons of wated.

7. TYPES OF SPRAY PUMPS IN GENERAL USE FOR SPRAYING POTATO CROPS.

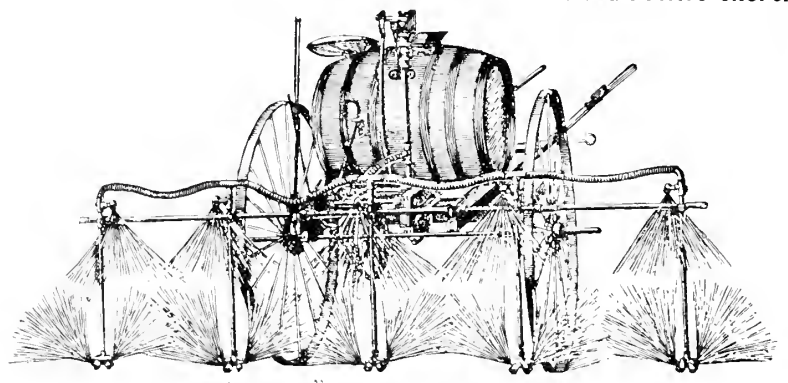

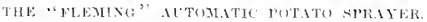

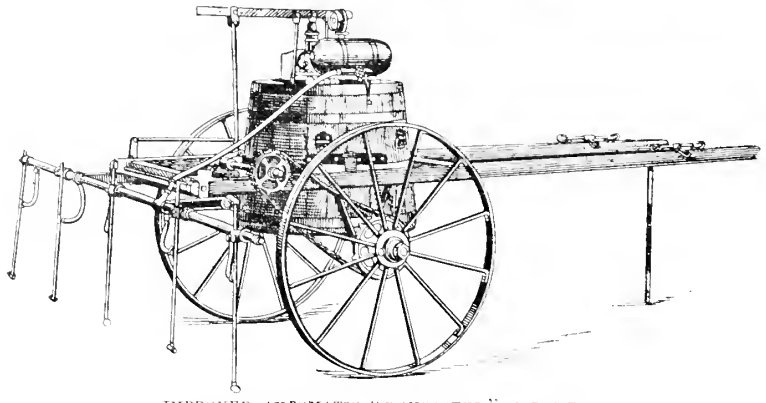

IHPRONED ML TUMLTIC" "D.NCANTER" SPRIXER.

THE RUTHERGLEN BUG.

(.Y.ius rinitor.)

This is one of the many plant bongs found in Victoria, and it is probably the most clestructive. The perfect insects measure about 11 lines in length, the general colour being greyish to light brown; the wings, with the exception of a few dark line-like markings when closed, are transparent. It is a very active insect, and has a habit of dropping or flying to the ground when plants, fruits, $d e$. on which it is resting are touched. The bug is furnished with a roxtrum or beak, with which it sucks the sup from the plants, and eathes them to wither and die. In the summer it is seen artually in thonsands on potuto and other crops, garden plants. \&e, therebr callsing growers consilereble loss.

Some years ago, the first specimens of this insect were sent in from Rutherglen. hence the name Rutherglen bug. At that time. the insects were doing much dam ine to vegutables, tomatoes. potatoes, and to all kinds of fruit. Various experiments were carried out by MLr. (C. French. Senior, for the suppression of the pest. and good results were obtained by asing the Benzole emnlsion spray. At that time no motor spray pumps were available, and spraying the potato crops with hand pumps was a tedious proceeding.

Prevestion ind Remedies.

See treatment recommended for thrips. 


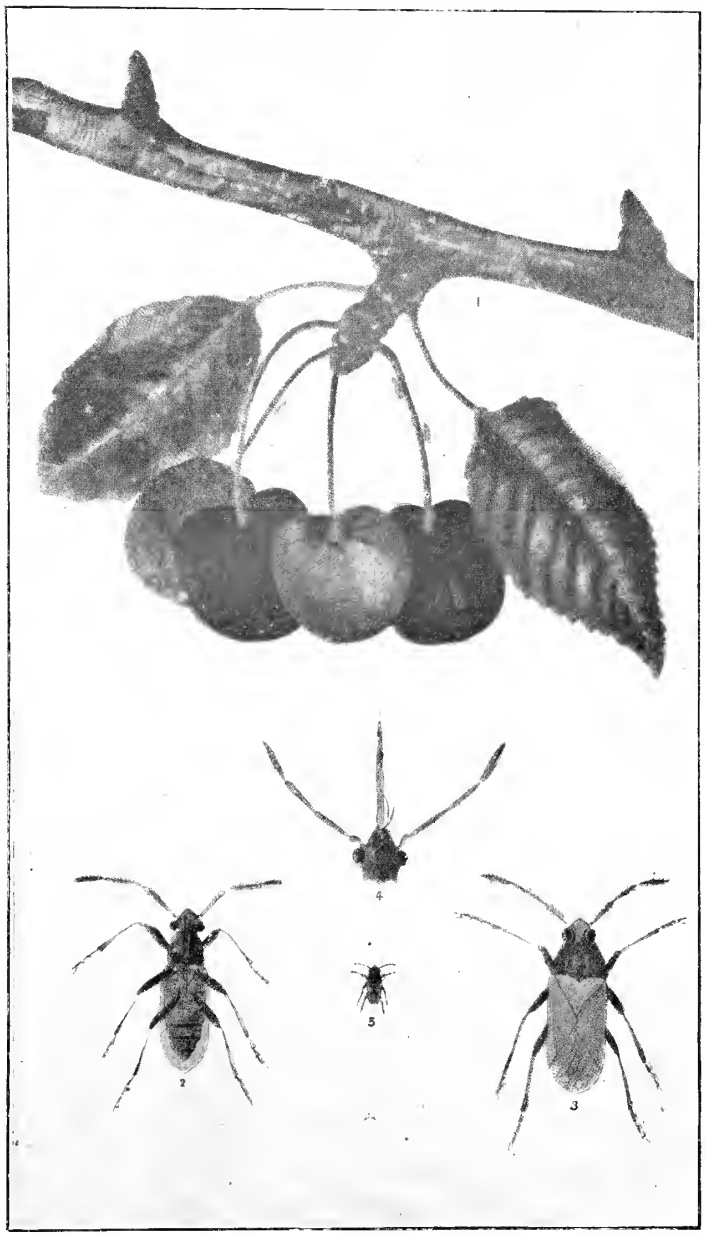

8. RUTherGlex BUG. (Nysizs vinitor.) After C. French. EXPLANATION OF PLATE.

Fig.

I. Branch of cherry tree, with fruit and insects. Tatural size.

II. Perfect insect. Under view. Magnified. 9276.
Fig. PiI. Perfect insect. Upper view. Magnified.

IV. Head of adult insect. Magnified.

V. Perfeet insoet. Natural size. 
WIRE WORMIS.

There are at consideribe number of species of wire worms found in vietoria. They betons to the family of Elreterida. 'Thir mature insects are known :- skip, Jack. (lick or Flip, Beetles, from their peeuliar ha: bit of springing into the air with a ctick, should they fall on their buek

The wire worm, whith is of at dak-brown shiming colour, varies from I to nearly 1 inch in length, being nsually about an thick as as match. The body is erdindricad, rathex that, compressed at the head and pointer behind : each of the first, serond and third segments of the thorax marries a pair of short legs. Wire worms have jowerfol mencibler or jaws. which are well adauted for hiting roots. The mature insects vary in fenstlo from $\frac{1}{2}$ to $1 \frac{1}{1}$ inches the colour leing generally dark brown or approacthing lisht bleck.

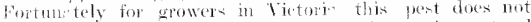
apperer to make much headway, no donbit owine to it naturat

9. WHER WORML. conemite. I bat outbreak ocoured some rears aso in the

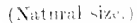

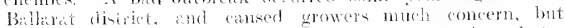
the troblile has not recoured. The acrompanying photo-

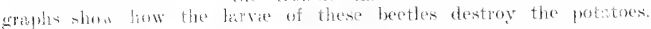

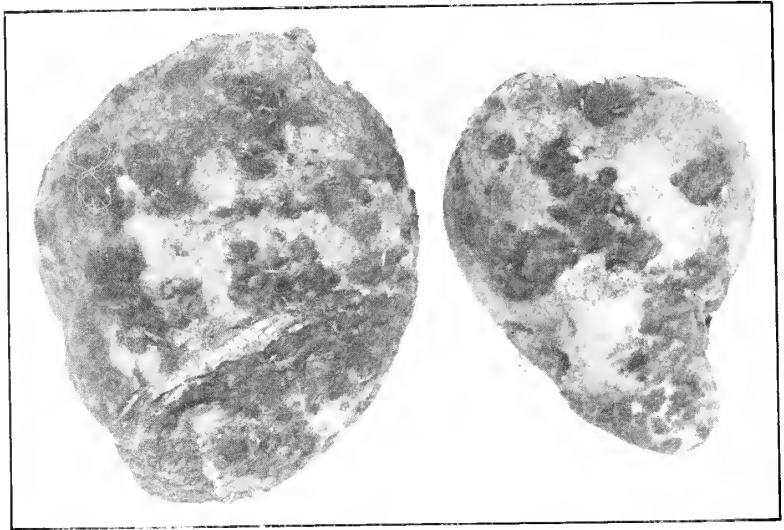

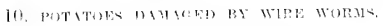

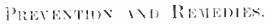

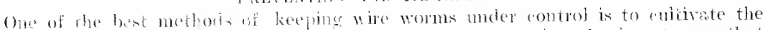

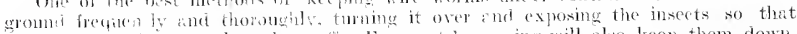
insedivorous hivis ene dear them whi frequent harrowing will also keep them down,

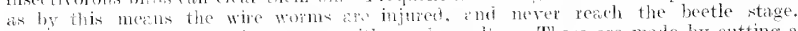

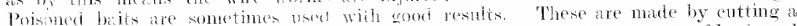

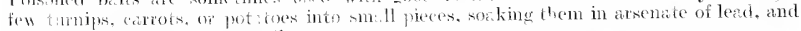
then putting them into ihe soil.

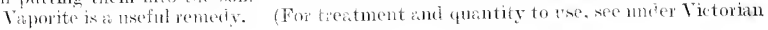
White Ant.)

\section{THE VICTORIAN WHITE ANT.}

(Termes loctis, Froweratt.)

The so-falled 11 hite sint. which has no aflinity to the true ant, is exceptionally common in mmo pits of this Ntate, and its lepredations are unfortunately well known. It is dicstroyer of timber and furniture, cos well as apricot, plum, and other

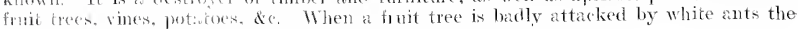

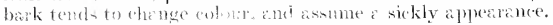




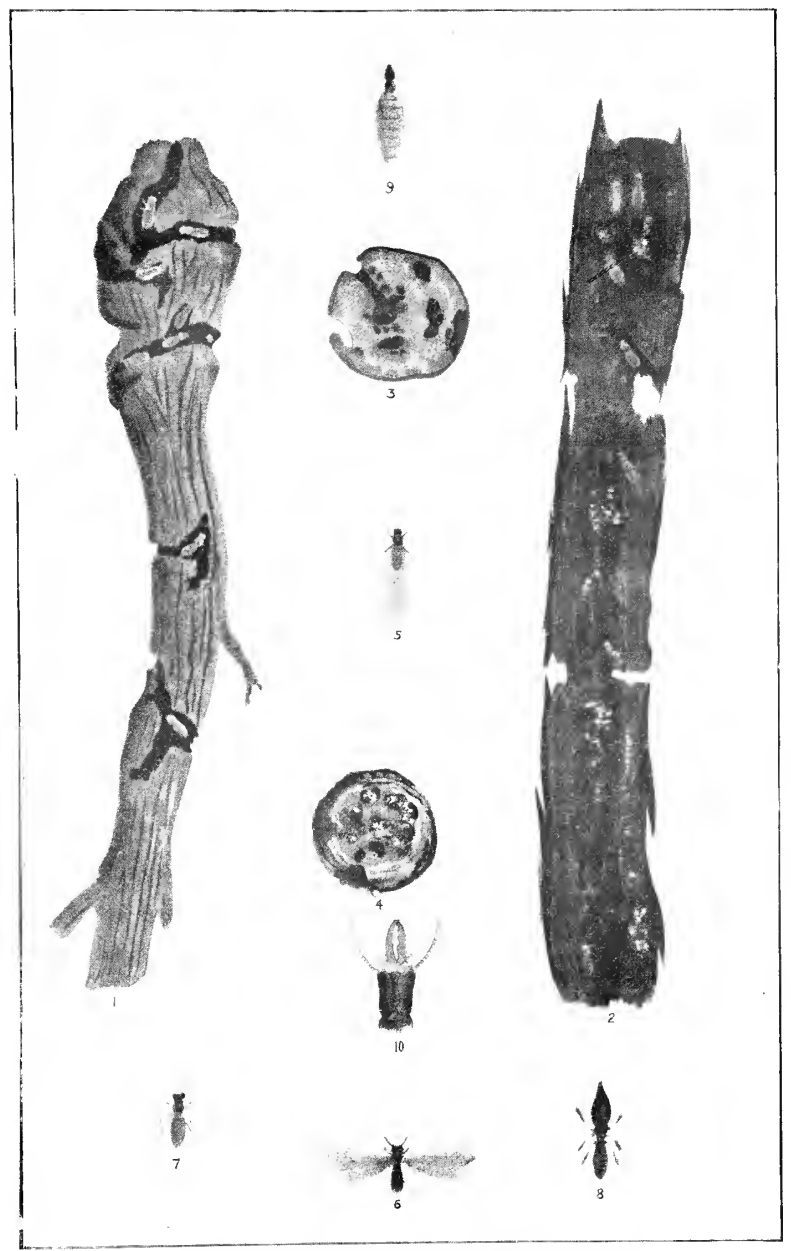

11. Fictoriax WHIta ANT. (Termes lactis, Froggatt.) EXPLAXATIOX OF PJATE.

I. Portion of orange root attacked loy white anto, showing ilsects at work and damage done. Natural sizt.

15. Portiou of yine stem attacked by white ant-, showing insects at work and lanmage done. Natural size.

III. Transverse section of orange root destroyed by white ants. Natural size.
Fig.

il. Transyerse kertion of vine root showing damage done fy white ants. Natural size

V. Male, with winge folded. Natural size.

vi. Male, with wing extended. Satural size.

Vll. Worker. Natural sizo.

VIIl Soldier. Natural size.

IX. Queen. Natulal size.

$\mathrm{X}$. Head of "Soldier White Ant," showing the powerful jaws. Magnitied. 
Fortmately for potato growers this pest does not seem to make much headway, but at the sume time it should be watched, for when once on mative insects leave their natural food there is mo telling what damaes they may do. The white ants aro small and of a velowish-white colon', and in creneral apuncarance, not molike true ants. 'They inhabit structures known as termiturian, which ise mounds or hillocks, in old roots of eucalyptus and other trees. The plate gives a gool idea of the varions phases of the white ant and its workintes.

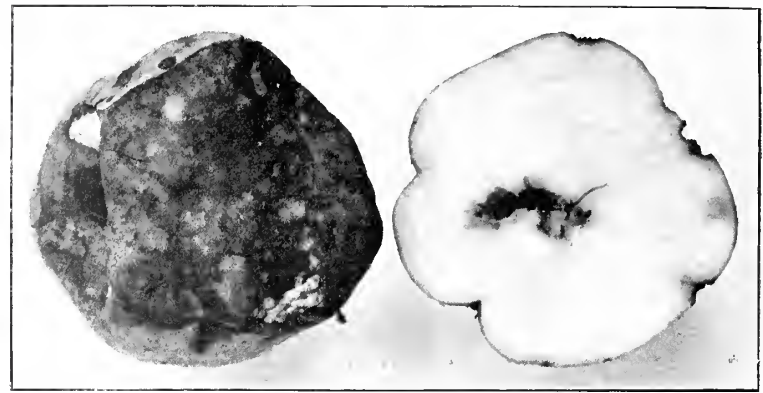

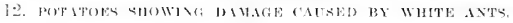

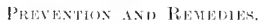

When it is interided to firm a potats field, the first thing to be done is to have all old stumps asid roots of trees removed and burnt. I have seen in many fields numbers of ofd stumps and roots of trees left, and on examination found them to be full of white ant in anll stages. Where they are allowed to harbor they are liable to attack potatoes, so the neressity of destroving their breeding plibes is obvions. A careful grower has vers little to fear from the atiuks of white ants if this precantion is taken.

When taking out old stmmps many white ants are likely to fall into the holes caused by their removal, and in such coses it is udvisable to pour a eupful of bisulphide of carbon into areh hole: cover it immediately, and stamp the soil well down. The fumes of the poison will destroy the ants. When using this chemical great care must be taken that no lights are placed near it as it is lighly inflammalse.

Inother plan is to dic Vaporite into the soil, which is then pressed firmly down. The quantity to be uned varies with the duancter of the soil; light soils require a loser amount than heavy ones. The lighter the soil the more easily is the mixing aflecterl. whl the more easily will the gas penetrate. The quantity of Paporite nsed is gencrally at the rate of 225 lbs. per ace for light soils, and about $350 \mathrm{lhs}$. for heavy soils, but for filling holes these quantities shonld be exceeded.

\section{MILLIPEDES.}

Milliperles are closely allied to inseets, but belong to another elass (Myriapoda, which includes centipedes). The body is erustaceous, the antennæe or feelers seven-jointed,

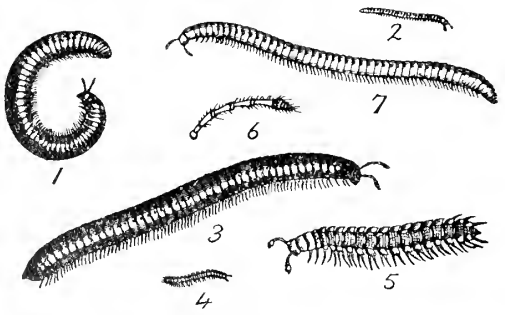

13. MILLTPEDES.

Fig.

I. Millipede. Magnified.

II. Natural size of No, 7 .

III. Millipede. Magnifted

IV. Natural size of No, 5 .

EXPLANATION OF PLATE.

Fig. V. Millipede. Magnified.

vi. Antenna or horn of Millipede. Magnifled.

VII. Millipede. Magnitied. (After Ormerod.) 
and the first segment of the body has the form of a little shield. The feet are numetous.

The eggs are laid in the ground amongst vegetation, \&e. The young Julide (Millipedes) live two years before they are perfect, during which time they grow and ehange their skin five times. They mantain the same appearance throughout, excepting for an increase in the number of legs.

Millipedes are both herbivorous and carnivorous in their habits. At times they attack young potato plants when just spronting under the soil, and on that account are mentioned here. In some localities in this State they do a certain amount of damage to other crops as well as potatoes.

\section{Prevention and Remedes.}

One of the best remedies is to thoroughly cultivate the land. Remove and destroy all rubbish under which they conld shelter. When they are in the ground Vaporite has given good results. The Vaporite should bo well incorporated with the soil to a suffieient lepth when the ground is cultivated. (Sce further particulars as to quantity $\therefore$ use under Victorian White Ant.)

Mr. W. E. Collinge, M.Se., Bitanighiam, in his First Report on Economic Biology, states that the following remedy has proved very suecessful. In flower beds, dig out a hole sufficiently large to contain the fist and wrist; fill with bran, and cover with water. After two or three duys pour on to the bran boiling water. The contents of two such holes were exa nined after tratment, and were found to contain 2,448 and 1,793 dead ...ullipedes respectively.

WOOD LICE, SLATERS, OR SOW BUGS.

This pest is destructive to potatoes, both in the field and when stored in pits. Wood lice are not, strictly speaking, insects, but as they catse considerable damage they are included in this article on potato insect pests.

Wood Lice belong to the Crustacea, a prime division of Arthropods, which includes lobsters, crabs, shrimps, prawns, \&c. The common wood louse is mostly nocturnal in its habits, retiring during the day under stones, débris, old bags, bark, and, in fact, almost any kind of hiding place that is accessible, and coming forth in the evening to feed. It has a peculiar habit of contracting itself into a ball when disturbed. The eggs are very small, shining, and pale yellow-white in colour ; they hatch rapidly under suitable conditions.

\section{Prevention and Remedies.}

Do not allow any debris, old bags, logs, \&e, to lie about on fields where it is intended to plant potatoes, as the animals may lodge there.

Traps.-Cook in a solution of arsenie a piece of parsnip, beetroot, or potato, and place it in the haunts of the wood lice. They will eat this greedily.

Mr. A. M. Lea says-

They ean be trapped in large numberz by placing empty boxes (or bones on top of old sacks) at the 2.t of the garden, and into these the wood lice will creep on the approach of day.

Should the wood lice be in the ground it would be advisable to treat the soil with Vaporite before sowing. Recent experiments conducted by the writer with this material proved very satisfactory. The Vaporite was well worked into the soil amongst the wood lice, and after a few days an examination of the ground showed the wood lice to be quite hlack, the gas from the Vaporite having destroyed them. 



\section{GENERAL INIEX.}

Arreage under potatoes, ('ommonwealth

Acreage under potatoes, linited Kingdom .. .

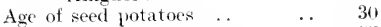

Alternaria. a weak parasite .. 57

Altemaria solani = early blight ..

Annual loss from potato blight in New Kealand . .

Annual loss from potato blight in Inited States .. ..

Application of dry heat .

Armillaria mellea = stringy rot..

Australian literature relating to Bacillus solunacearum = wet rot..

Bucille $s p$. . . . . .

Bacteria and pilant diveases ..

Black dot divense

Black leg or black stalk rot $\quad . \quad 90$

Black nightshade, immune to potato blight .. ..

Black scab or eaulílower disease

Black speeck or sclerotial seab ..

Black stalk rot or black leg ..

Brown fleck or internal brown spot

Brown ring .. $\quad$. $\quad$..

Brown rot or wet rot. . .

Brown rust ‥ 4. 3. 37. 6i2

Cauliflower disease or black seab is

('hlamydospores or resting-spores of dry rot .. .

Conditions under which potato blight oceurs in Australia.. 16

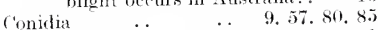
in clusters in dry rot .. 81 germination in dry rot . 81. 8.) germination in early $\begin{array}{llll}\text { blight } & . & \ldots & 57\end{array}$

ronstituents of the potato $\quad$. 54

fontradictions, seeming recon-

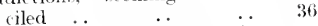

forrosive sul limate for rhizoctonia rot ..

Corrosive sullimate for scab $\quad \ldots 72,77$

cultivation in relation to potato blight .. $\quad . \quad 26,41,59$

Definite determination of potato

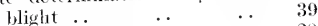

Destrnction of refuse $\quad . \quad 2 \quad \ldots \quad 28$

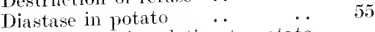

Digging time in relation to potato blight .. . 23

Discovery of potato blight in each of the States .. ..
Diseases associated with Irish $\begin{array}{llll}\text { blight .. } & \text {.. } & \text {. } & 23\end{array}$

1)isease-resisting varieties $\quad$. 29

$\begin{gathered}\text { Disinfection of seed potatoes by } \\ \text { dry heat }\end{gathered}$..
...

Distribution of potato blight in relation to rainfall $\quad$. $\quad 19$

Distribution of rhizoctonia rot ..

$\begin{array}{lll}\text { wet rot } & \text {.. } & 88\end{array}$

Distribution of spores by wind

$8,14,16,33,38$

Dormant mycelium, infection by 15

$\begin{array}{llll}\text { Drainage } & . & \ldots & 28,91,95\end{array}$

Dry heat. application of $\quad . .51$

disinfection of seed potatoes by $\quad . \quad$..

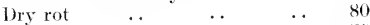

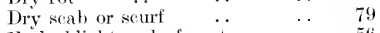

Wirly blight or leaf spot $\quad$.. 56 conditions favouring $\quad . .54$

fungus causing $\quad \ldots \quad$.. 57

hibernating nycelium $\quad \ldots \quad 58$

$\begin{array}{llll}\text { host-plants } & \text {. } & \text {.. } & 58\end{array}$

$\begin{array}{llll}\text { symptoms } & . & . & 50\end{array}$

$\begin{array}{llll}\text { treatment } & . & \ldots & 58\end{array}$

Ergot, an example of selerotium 61

Factors influencing potato blight 25

Field cxperiments $52,53,67,73,7+$

Formalin treatment

$24,41,73,74,75,86$

Fusarium oxy.uporum = dry not .. 80 infection of potato by potato 82 potato by tomato 83 tomato by tomato 83 tomato by potato 83

$\begin{array}{llll}\text { life history } & \ldots & \ldots & 8.5\end{array}$

preventive measures $\quad$. 8.5

Germination of conidia of dry rot $81,8.5$ early blight $\quad 57$ swimming spores of 9

Heat and moisture in relation to potato blight .. . 25

Heated and unheated blighted seed

$\begin{array}{llll}\text { potatoes } & \text {. } & \text {. } & 53\end{array}$

Heated and unherted seed
potatoes
He

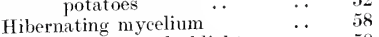

Host plants of early blight $\quad . .5 \%$ potato blight $\cdots \quad 23$ $\begin{array}{lll}\text { potato blight } & . & 23 \\ \text { rhizoctonia rot } & . & 60\end{array}$ $\begin{array}{lll}\text { wet } \operatorname{rot} . . & . & 88\end{array}$

Humidity, influence on potato 17 
IIypochnus solani $=$ rhizoctonia rot

Hypoehnus or reproductive stage cf rhizoctonia rot

60

Immunity of black nightshare to potato blight .. ..

Infection, artificial

by dormant myeelium $\quad \ldots \quad$ la

mutual by spores from potato and tomato ...

from planting discased rets

of potato tops only unbroken skin $\cdot \cdot$

principal modes of

Inscets transmitting disease of wet rot

Internal brown spot or brown fleck

Irish blight and tomatoes

definite determination of

diseases associated with

factors influencing

$25,26,27,28,29$

first appearance in potatocs in Australia

first appearance in tomatocs in Australia

points of practical importance

20

preventive measures

Kangaroo apple, subject to potato blight . .

Late blight or potato blight

Leaf spot

Lenticels

..

23

23
4

. 56

66,100

ife-history of dry rot fungus .. potato blight fungus $\quad \ldots \quad 8$ rhizoctonia rot fungus $\quad \ldots \quad$ ij

Literature, Australian, relating to potato discases...

Losses caused by potato blight

101 wet rot..

Manuring in relation to potato blight ..

Misses in the potato crop

Modes of infection in-

dry rot

potato blight

wet rot ..

..

..

Moisture in potatoes, loss of on heating

Mycelium, hibernating or winter ing of potato blight early blight . . persistence of vitality in potato blight ..

Oospora scab..

Oospora scabies $=$ American seab

Oospores of potato blight produced in artificial cultures

Parasite, weak

Phytophthora infestans $=$ potato blight ..

Points of practical importance concerning potato blight

Potato blight or late blight $\quad$. conditions under which it occurs in Australia

i)

3

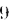
5

0

0

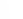


PAGK

Scab-continued.

\begin{tabular}{|c|c|c|}
\hline $\begin{array}{l}\text { in Australia } \\
\text { other eountries }\end{array}$ & $\begin{array}{l}\cdots \\
\ldots\end{array}$ & $\begin{array}{l}\cdots \\
\cdots\end{array}$ \\
\hline oospora .. & . & $\therefore 71,7$ \\
\hline potato $\quad$. & . & . 6 \\
\hline rhizoetonia & . & . \\
\hline selerotial & .. & . \\
\hline so-ealled .. & . & . \\
\hline spongospora & . & . \\
\hline treatment & . & $\cdots$ \\
\hline true $\quad \ldots$ & $\cdots$ & $\cdots$ \\
\hline se of term & & \\
\hline
\end{tabular}

Seabby seed, results of treatment

$\begin{array}{lllll}\text { of } & \text {. } & \ldots & \ldots & 73\end{array}$

Selerotial scab or blaek speck .. 75

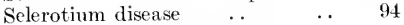

Selerotium or resting stage of rhizoetonia rot $\quad \ldots \quad \ldots 61$

$\begin{array}{llll}\text { Seurf or dry seab } & \text {. } & \ldots & 79\end{array}$

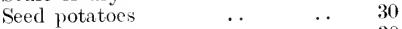

$\begin{array}{lllll}\text { age } & \text {. } & \ldots & \ldots & 30\end{array}$

boxing or traying .. $\quad$.. $\quad 30$

disinfection by divy heat . . 50

$\begin{array}{llll}\text { early dug } & \ldots & \ldots & 30\end{array}$

heated and unheated .. 52

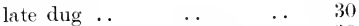

sprouted and unsprouted .. 30

$\begin{array}{lllll}\text { steeps } & \ldots & \ldots & \ldots & +1\end{array}$

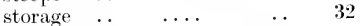

Serming contradictions reconciled $\quad 36$

Skin of potato $\quad$. $\quad \ldots \quad 66$

Soil, in relation to potato blight. . $\quad 26$

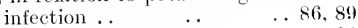

$\begin{array}{llll}\text { temperatures } & \ldots & \ldots & \mathbf{2} 6\end{array}$

Spindle clisease or thready eye .. 98

Spongospora subtemanea $=$ pow-

Spondylocladium atro-riren: $=$ $\begin{array}{llll}\text { dry seab } & \text {. } & \ldots & 79\end{array}$

$\begin{array}{llllll}\text { Siporangia } & \ldots & . & \ldots & \ldots & 8\end{array}$

for artificial infection $\quad . \quad 22$

$\begin{array}{lllll}\text { Spores } & \ldots & \ldots & \ldots & 8\end{array}$ distribution by wind

8, $14,16,33,38$

effect of being kept dry
Spores-continued.

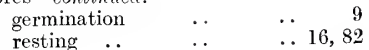

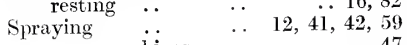

$\begin{array}{llrr}\text { machines } & \ldots & . . & 47 \\ \text { mixtures } & . & . & 44 \\ \text { prevention } & \text { of potato } & \end{array}$

$\begin{array}{lccc}\text { prevention } & \text { of } & \text { potato } & \\ \text { blight by } & \text {.. } & . . & 42\end{array}$

$\begin{array}{lll}\text { Spread of potato blight } & \ldots & 33\end{array}$

Siprouted and unsprouted seed .. 30

Steeps for seed potatoes $\quad$. 41

Storage of seed potatces $\quad$. 32

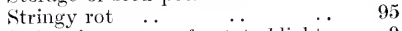

Swimming spores of potato blight 9 germination $\quad . \quad \quad . .99$

Synchytrium endobioticum = black seab or cauliflower disease 78

Temperature in relation to potato $\begin{array}{ccccc}\text { blight } & . . & . & \ldots & 25 \\ \text { soil } & \ldots & . & . & 26\end{array}$

Thready eye or spindle disease .. 98

Time of digging for blighted potatoes 28

Tomatoes and Irish blight $\quad . \quad 20$

Treatment of early blight $\quad$. $\quad$ ร8 potato blister and scab, $\quad \ldots \quad 72$ rhizoctonia rot $\quad \ldots \quad \ldots .65$ $\begin{array}{lllll}\text { scab } & \text {. } & \ldots & \ldots & 72\end{array}$

Tree-killing fungus on potato . 95

rarieties, disease-resisting $\quad \ldots .29$

Vegetative stage of rhizoctonia . $\quad 63$

Termicularia varians $=$ black dot $\begin{array}{llll}\text { disease } & \text {. } & \text {. } & 92\end{array}$

Vitality of mycelium .. $\quad$.. 14

Water eulture $\quad$. $\quad \ldots \quad 35$

Wet rot or brown rot .. $\quad \ldots \quad 87$ $\begin{array}{llll}\text { distribution } & \ldots & \ldots & 88\end{array}$ $\begin{array}{llll}\text { host-plaits } & \ldots & \ldots & 88\end{array}$ losses eaused by $\quad . \quad 0 \quad \ldots \quad 89$ organism causing disease .. 88 $\begin{array}{lll}\text { preventive measures } & \text {. } & 89\end{array}$ $\begin{array}{llll}\text { symptoms } & \ldots & \ldots & 87\end{array}$

Wind distribution of spores

$\begin{array}{lrr}\text { Wintering of mycelinm } & \ldots & 9,58 \\ \text { Woburn Bordeaux paste } & \ldots & \mathbf{4 7} \\ \text { Zoospores or swarm spores } & \ldots & 9,25\end{array}$ 
In this Map the customary shades of blue to represent different degrees , of rainfall have not been used, but striking colours are employed to show the grower at a glance the average rainfall of any particular district. 


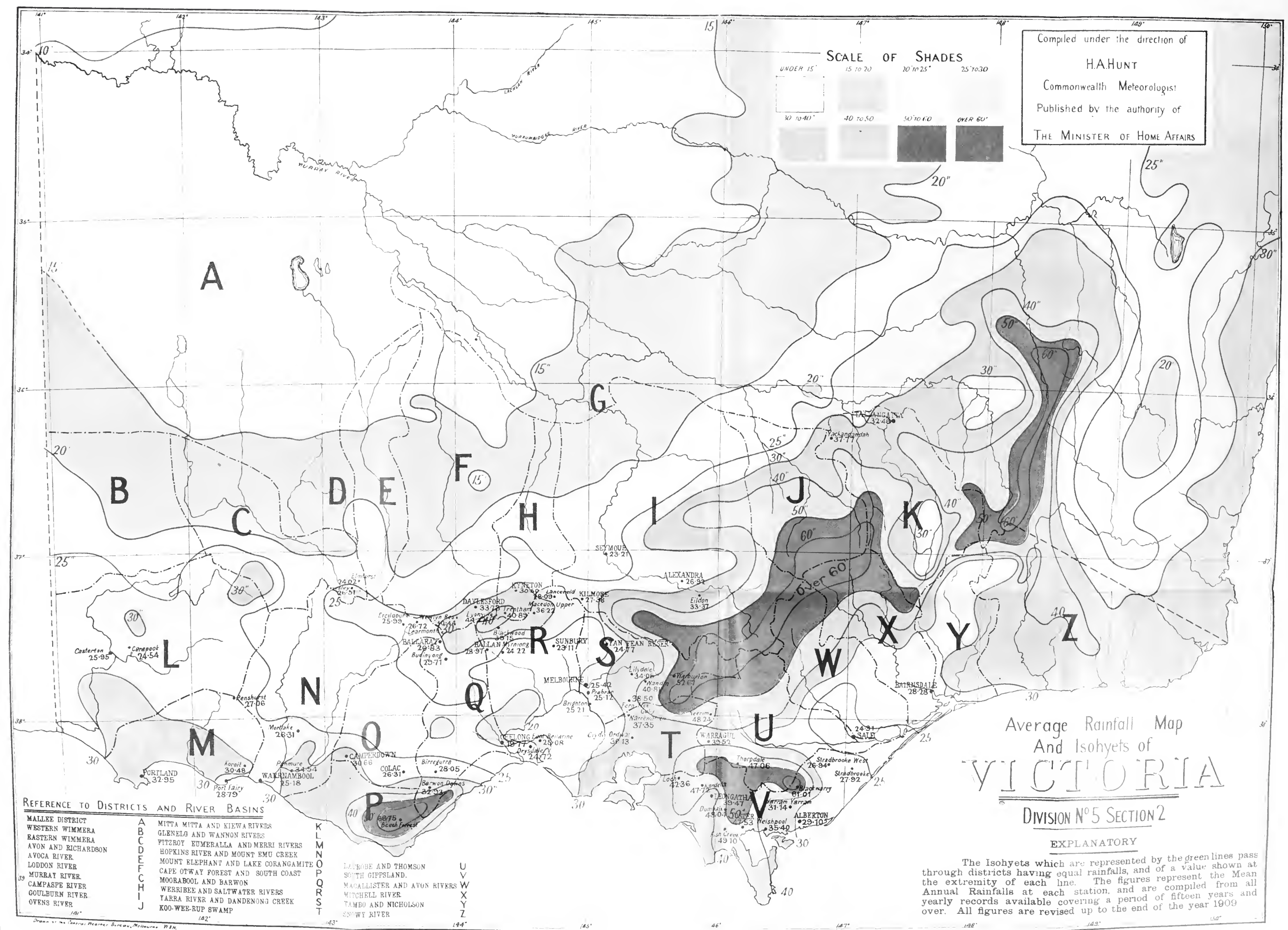


so 
$C$

S

$63=491$ 
